US Army Corps of Engineers $s_{\circledast}$

Engineer Research and Development Center

\title{
Three-Dimensional Eutrophication Model of Lake Washington, Washington State
}

Carl F. Cerco, Mark R. Noel, and Sung-Chan Kim

August 2004

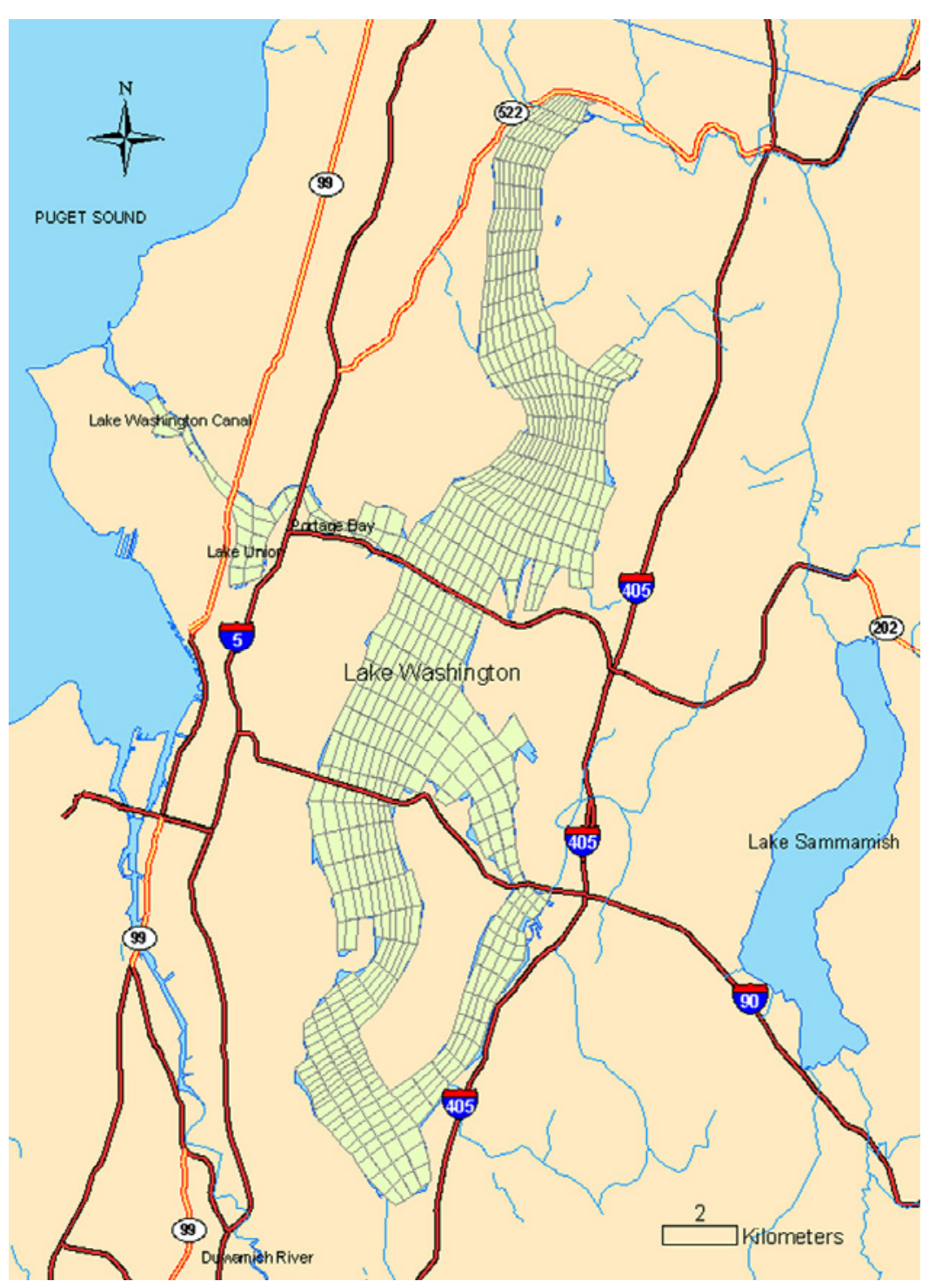




\section{Three-Dimensional Eutrophication Model of Lake Washington, Washington State}

Carl F. Cerco, Mark R. Noel, and Sung-Chan Kim

Environmental Laboratory

U.S. Army Engineer Research and Development Center

3909 Halls Ferry Road

Vicksburg, MS 39180-6199

Final report

Approved for public release; distribution is unlimited

Prepared for King County Department of Natural Resources and Parks Seattle, WA 98104 


\begin{abstract}
The CE-QUAL-ICM three-dimensional eutrophication model was applied to Lake Washington, northwestern Washington State, for the period 1995-1997. Transport processes were obtained from the companion CH3D-WES hydrodynamic model. The model activated 18 state variables in the water column including physical variables; phytoplankton; multiple forms of carbon, nitrogen, and phosphorus; dissolved oxygen; and fecal coliform. The model provided excellent representation of the annual cycle of temperature, chlorophyll, nutrients, and dissolved oxygen in the lake. The vertical structure was also wellrepresented. The water column was coupled to a predictive sediment diagenesis model that computed sediment-water fluxes of dissolved oxygen, methane, ammonium, nitrate, and phosphate, based on computed inputs of particulate organic matter. Computed values of deposition and fluxes were in reasonable agreement with published values. Nutrient loads were calculated and nutrient budgets were constructed as part of the model exercise. Load sources included river inflows, distributed loads, sewer overflows, and atmospheric loading. The Sammamish River was identified as the largest source of nutrients to Lake Washington, followed by the Cedar River and other distributed sources. The majority of the nutrient load is deposited in the sediments. A lesser amount leaves via Lake Union. Nutrient loads in this study were 30 percent (nitrogen) to 60 percent (phosphorus) higher than the loads from the late 1970's.
\end{abstract}

DISCLAIMER: The contents of this report are not to be used for advertising, publication, or promotional purposes. Citation of trade names does not constitute an official endorsement or approval of the use of such commercial products. All product names and trademarks cited are the property of their respective owners. The findings of this report are not to be construed as an official Department of the Army position unless so designated by other authorized documents. 


\section{Contents}

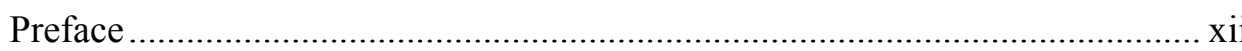

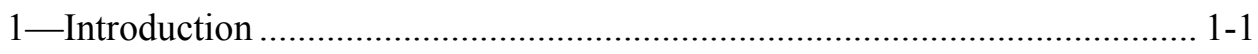

Lake Washington ................................................................................ 1-1

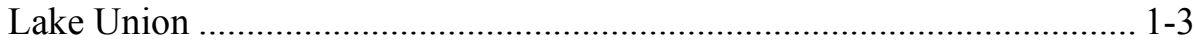

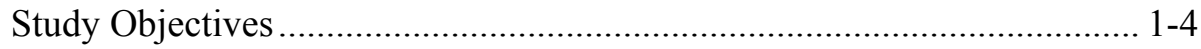

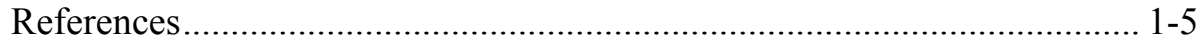

2-Flows, Loads, and Boundary Conditions ............................................... 2-1

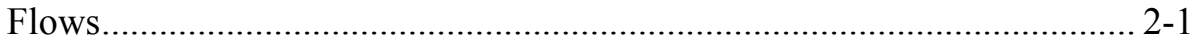

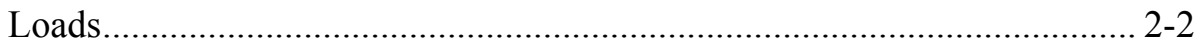

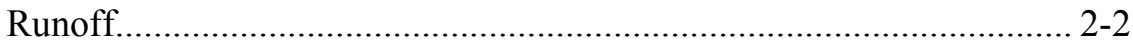

Combined-sewer overflows.............................................................. 2-3

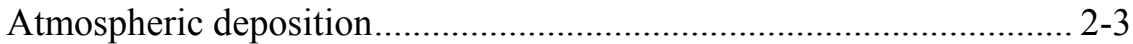

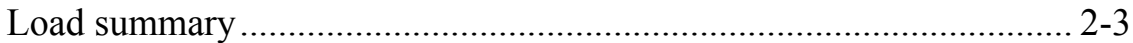

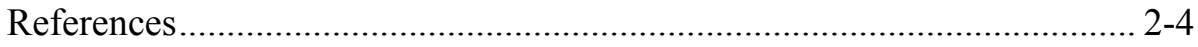

3-Water Quality Model Formulation ......................................................... 3-1

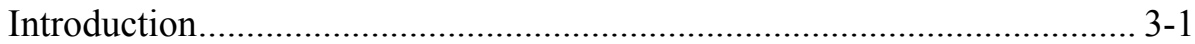

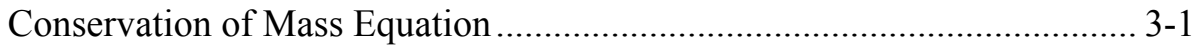

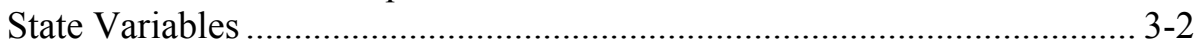

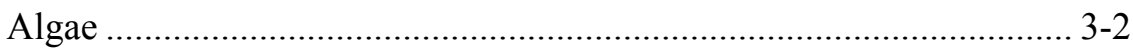

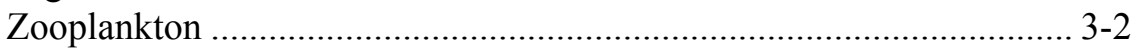

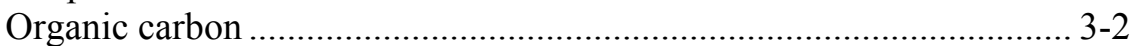

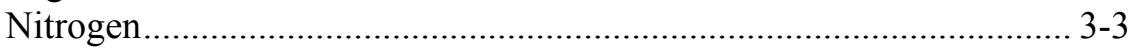

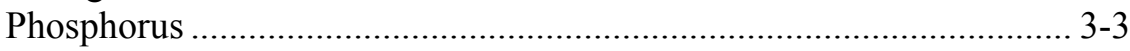

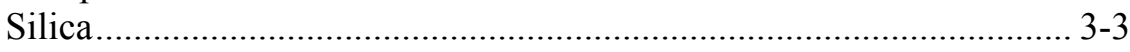

Chemical oxygen demand ...................................................... 3-3

Dissolved oxygen .................................................................... 3-3

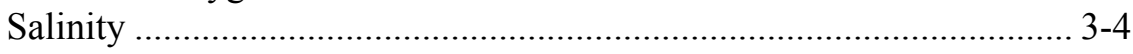

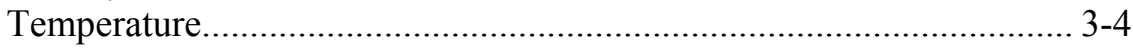

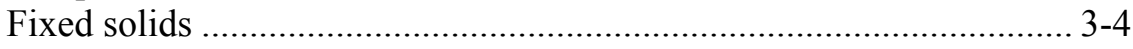

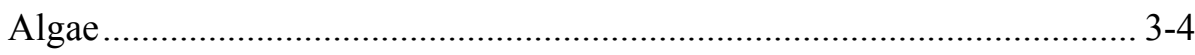

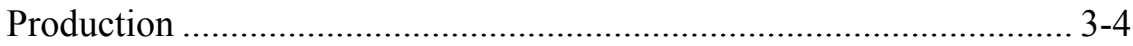

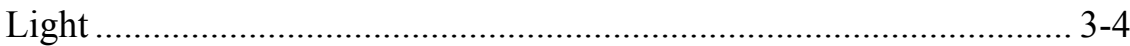

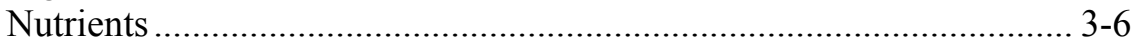

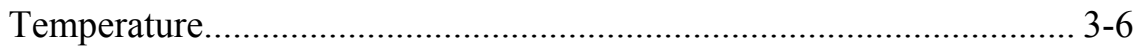

Constructing the photosynthesis versus irradiance curve ...................... 3-7 


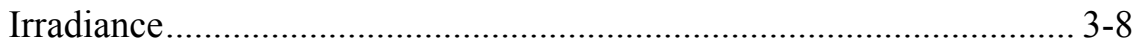

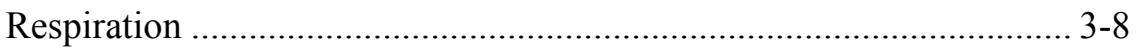

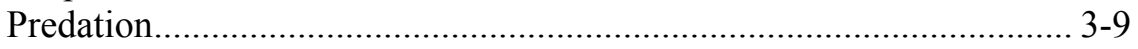

Accounting for algal phosphorus ..................................................... 3-9

Accounting for algal nitrogen................................................... 3-10

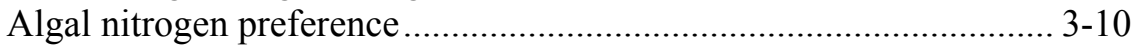

Effect of algae on dissolved oxygen............................................. 3-11

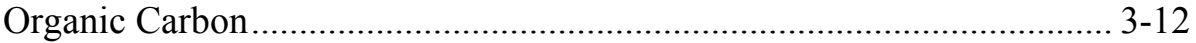

Dissolution and respiration................................................................ 3-13

Dissolved organic carbon ................................................................... 3-14

Labile particulate organic carbon ................................................... 3-15

Refractory particulate organic carbon ........................................... 3-15

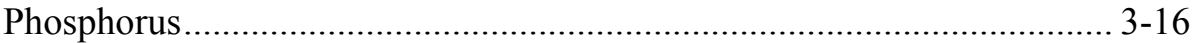

Hydrolysis and mineralization...................................................... 3-16

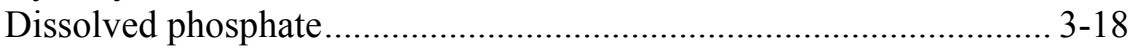

Dissolved organic phosphorus...................................................... 3-18

Labile particulate organic phosphorus ............................................ 3-19

Refractory particulate organic phosphorus......................................... 3-19

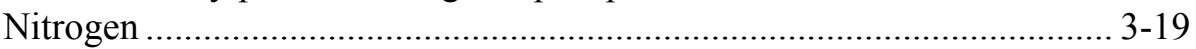

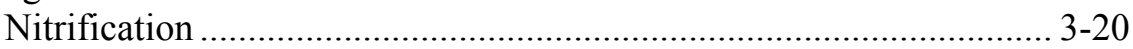

Effect of denitrification on nitrate ................................................. 3-22

Nitrogen mass balance equations .................................................... 3-22

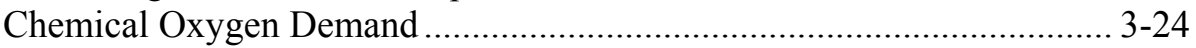

Dissolved Oxygen ............................................................................ 3-24

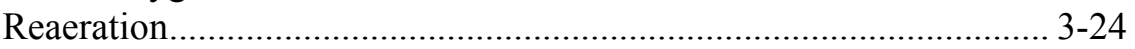

Mass balance equation for dissolved oxygen ................................. 3-26

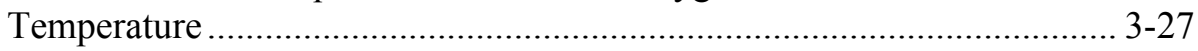

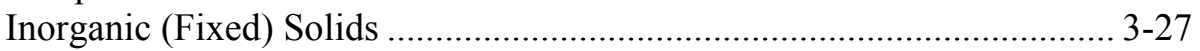

Parameter Values ................................................................................. 3-27

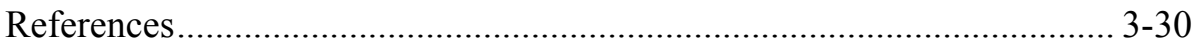

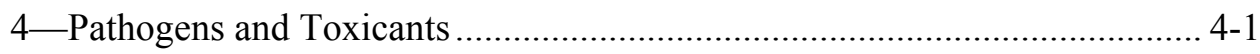

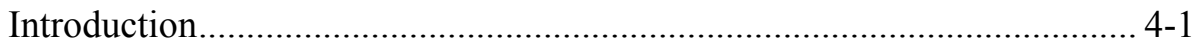

Conservation of Mass Equation ............................................................... 4-1

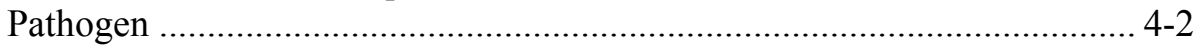

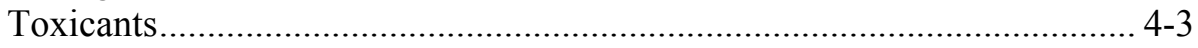

Reactions in the water column ...................................................... 4-3

Particulate and dissolved fractions ....................................................... 4-4

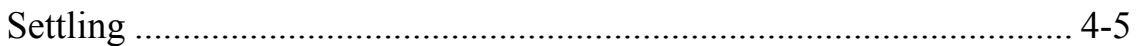

Reactions in the sediments ............................................................. 4-5

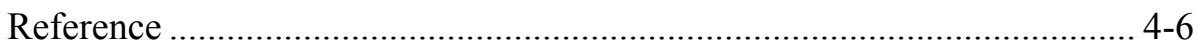

5-Modeling Processes at the Sediment-Water Interface .................................. 5-1

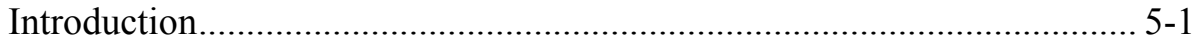

Coupling With the Sediment Diagenesis Model........................................ 5-2

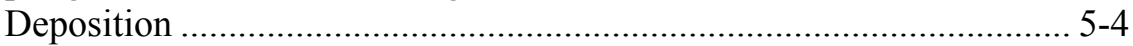

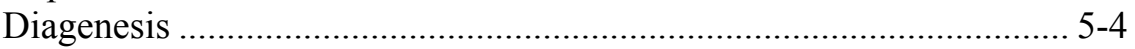

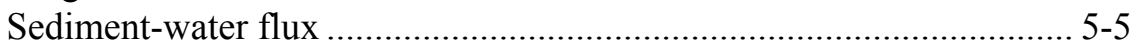

Parameter Specification ........................................................................ 5-6

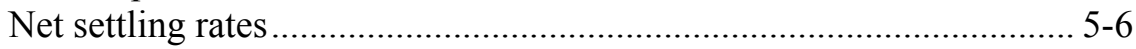

Assignment to $\mathrm{G}$ classes................................................................. 5-6 


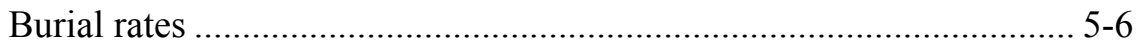

Sediment model parameters ............................................................. 5-7

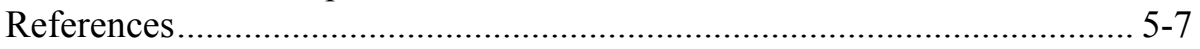

6-Coupling with the Hydrodynamic Model ................................................... 6-1

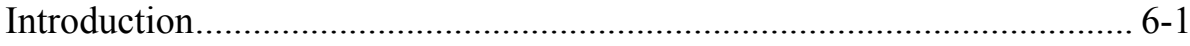

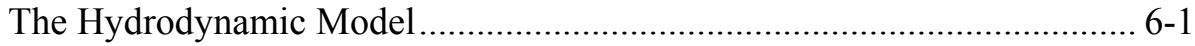

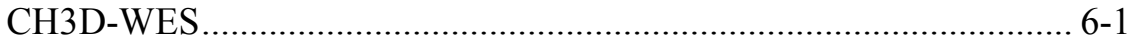

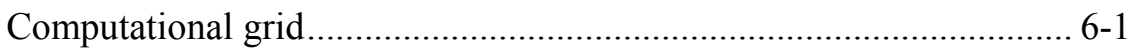

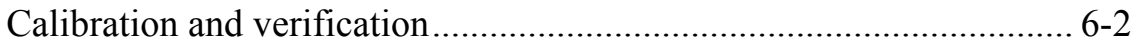

Linkage to the Water Quality Model ......................................................... 6-2

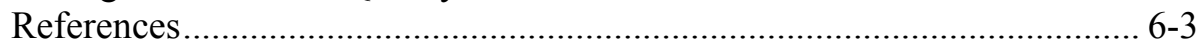

7-Observation-based Calibration ............................................................ 7-1

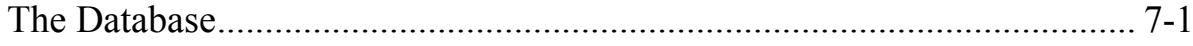

Format of Model-Data Comparisons ................................................... 7-2

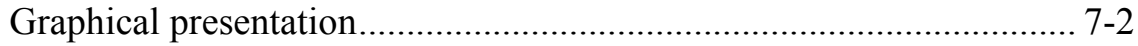

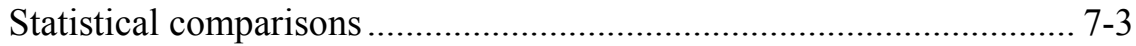

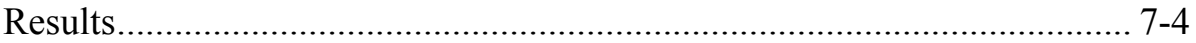

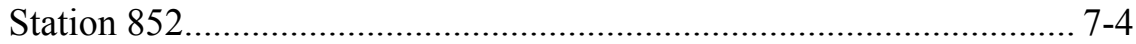

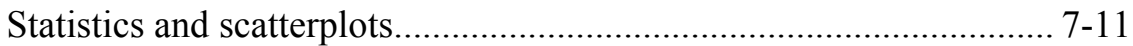

Comparison with other systems .................................................. 7-13

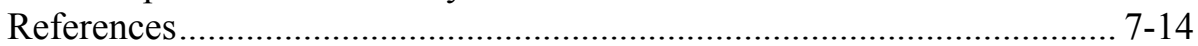

8-Process-based Verification .................................................................... 8-1

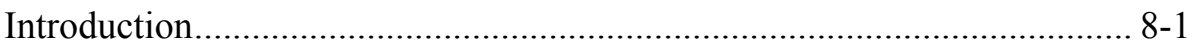

Primary Production .............................................................. 8-1

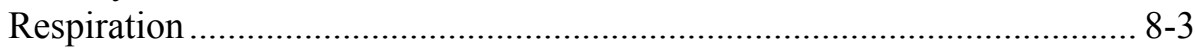

Deposition and Sediment-Water Fluxes ............................................. 8-5

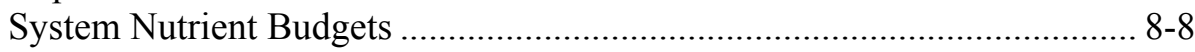

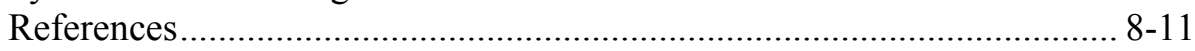

9-Summary, Conclusions, Recommendations ......................................... 9-1

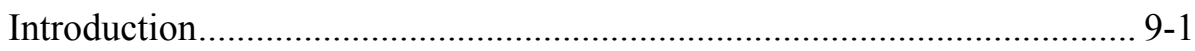

Flows, Loads, Boundary Conditions....................................................... 9-1

Water Quality Model Formulation............................................................ 9-2

Modeling Processes at the Sediment-Water Interface ............................... 9-3

Coupling with the Hydrodynamic Model .................................................. 9-3

Observation-based Calibration........................................................... 9-4

Process-based Verification...................................................................... 9-5

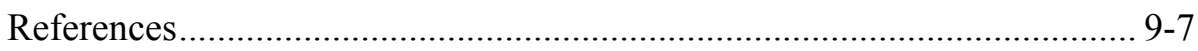

SF 298 


\section{List of Figures}

Figure 1-1 Lakes Washington and Union ................................................ 1-2

Figure 1-2. Watershed of three lakes .................................................. 1-3

Figure 2-1. Locations of gauged and distributed flows............................. 2-8

Figure 2-2. Distributed flow basins....................................................... 2-9

Figure 2-3. Flow in Cedar River ........................................................ 2-10

Figure 2-4. Flow in Sammamish River ................................................. 2-10

Figure 2-5. Flow in Thornton Creek ................................................... 2-11

Figure 2-6. Distributed flows ............................................................. 2-11

Figure 2-7. Location of sewer overflows and spills ............................. 2-12

Figure 2-8. Daily nitrogen load from Cedar River................................. 2-13

Figure 2-9. Daily nitrogen load from Sammamish River......................... 2-13

Figure 2-10. Daily nitrogen load from Thornton Creek............................. 2-14

Figure 2-11. Daily nitrogen load from distributed sources ........................ 2-14

Figure 2-12. Daily nitrogen load from sewer overflows and spills............ 2-15

Figure 2-13. Daily phosphorus load from Cedar River............................... 2-15

Figure 2-14. Daily phosphorus load from Sammamish River ................... 2-16

Figure 2-15. Daily phosphorus load from Thornton Creek........................ 2-16

Figure 2-16. Daily phosphorus load from distributed sources .................... 2-17

Figure 2-17. Daily phosphorus load from sewer overflows and spills....... 2-17

Figure 2-18. Daily fecal coliform load from Cedar River.......................... 2-18

Figure 2-19. Daily fecal coliform load from Sammamish River ............... 2-18

Figure 2-20. Daily fecal coliform load from Thornton Creek.................... 2-19

Figure 2-21. Daily fecal coliform load from distributed sources ................ 2-19

Figure 2-22. Daily fecal coliform load from sewer overflows and

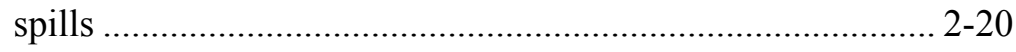

Figure 2-23. Daily suspended solids load from Cedar River ..................... 2-20 
Figure 2-24. Daily suspended solids load from Sammamish River.

Figure 2-25. Daily suspended solids load from Thornton Creek ................ 2-21

Figure 2-26. Daily suspended solids load from distributed sources ........... 2-22

Figure 2-27. Daily suspended solids load from sewer overflows and

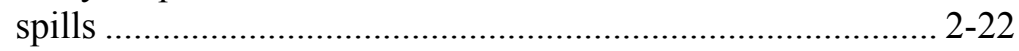

Figure 3-1. Production versus irradiance curve ..................................... 3-5

Figure 3-2. Michaelis-Menton formulation for nutrient-limited growth ................................................................................. 3-6

Figure 3-3. Relation of algal production to temperature ........................... 3-7

Figure 3-4. Effects of light and nutrients on production versus irradiance curve, calculated for $\alpha=8\left(\mathrm{~g} \mathrm{C} \mathrm{g}^{-1} \mathrm{Chl}\right.$

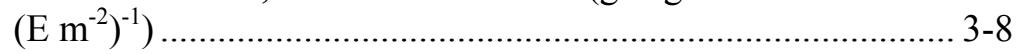

Figure 3-5. Exponential temperature relationship employed for metabolism and other processes ........................................... 3-9

Figure 3-6. Algal ammonium preference ................................................ 3-11

Figure 3-7. Model carbon cycle ........................................................ 3-13

Figure 3-8. Effect of dissolved oxygen and nitrate on denitrification ...... 3-14

Figure 3-9. Model phosphorus cycle................................................. 3-16

Figure 3-10. Effect of algal biomass and nutrient concentration on phosphorus mineralization ................................................. 3-18

Figure 3-11. Model nitrogen cycle................................................... 3-20

Figure 3-12. Effect of dissolved oxygen and ammonium concentrations on nitrification rate...................................... 3-22

Figure 3-13. Dissolved oxygen sources and sinks .................................. 3-25

Figure 3-14. Computed and tabluated values of $R v$................................ 3-26

Figure 4-1. Effect of temperature on pathogen decay ............................... 4-2

Figure 4-2. Schematic of toxicant model …................................................ 4-3

Figure 5-1. Sediment model schematic ................................................. 5-2

Figure 5-2. Sediment model elevation ……........................................... 5-3

Figure 6-1. Plan view of Lake Washington grid ...................................... 6-4

Figure 6-2. Elevation of Lake Washington grid ......................................... 6-5

Figure 6-3. Plan view showing number of vertical cells.......................... 6-6 
Figure 6-4. Comparison of daily average temperatures computed by hydrodynamic (CH3D) and water quality (ICM) models

Figure 7-1. Lake Washington sample stations ........................................ 7-15

Figure 7-2. Lake Union sample stations ….......................................... 7-16

Figure 7-3. Observed and computed surface temperatures at Station 852.

Figure 7-4. Observed and computed middepth temperatures at Station 852

Figure 7-5. Observed and computed bottom temperatures at Station 852.

Figure 7-6. Observed and computed temperature profiles at Station 852 for 1995

Figure 7-7. Observed and computed temperature profiles at Station 852 for 1996

Figure 7-8. Observed and computed temperature profiles at Station 852 for 1997

Figure 7-9. Observed and computed surface chlorophyll at Station 852.

Figure 7-10. Chlorophyll computed with low, constant predation rate compared to observations at Station 852

Figure 7-11. Computed components of light attenuation at Station 852.

Figure 7-12. Computed surface fixed solids at Station 852 ...................... 7-22

Figure 7-13. Observed and computed Secchi depth at Station 852 ........... 7-23

Figure 7-14. Observed and computed surface ammonium at Station 852 $7-23$

Figure 7-15. Observed and computed middepth ammonium at Station 852 .

Figure 7-16. Observed and computed bottom ammonium at Station 852 $7-24$

Figure 7-17. Observed and computed surface nitrate at Station 852 ......... 7-25

Figure 7-18. Observed and computed nitrate profiles at Station 852 for 1997 $7-26$

Figure 7-19. Observed and computed middepth nitrate at Station 852...... 7-27

Figure 7-20. Observed and computed bottom nitrate at Station 852 ......... 7-27 
Figure 7-21. Observed and computed surface total nitrogen at Station 852

Figure 7-22. Observed and computed middepth total nitrogen at Station 852

Figure 7-23. Observed and computed bottom total nitrogen at Station 852

Figure 7-24. Observed and computed surface ortho-phosphorus at Station 852

Figure 7-25. Observed and computed middepth ortho-phosphorus at Station 852

Figure 7-26. Observed and computed bottom ortho-phosphorus at Station 852

Figure 7-27. Observed and computed bottom ortho-phosphorus at Station 852 for 1995 .

Figure 7-28. Observed and computed ortho-phosphorus profiles at Station 852 for 1996 .

Figure 7-29. Observed and computed ortho-phosphorus profiles at Station 852 for 1997. 7-33

Figure 7-30. Observed and computed surface total phosphorus at Station 852

Figure 7-31. Observed and computed middepth total phosphorus at Station 852

Figure 7-32. Observed and computed bottom total phosphorus at Station 852

Figure 7-33. Observed and computed total phosphorus profiles at Station 852 for 1995 7-36

Figure 7-34. Observed and computed total phosphorus profiles at Station 852 for 1996

Figure 7-35. Observed and computed total phosphorus profiles at Station 852 for 1997. $7-38$

Figure 7-36. Observed and computed surface particulate organic carbon at Station 852

Figure 7-37. Observed and computed bottom particulate organic carbon at Station 852

Figure 7-38. Observed and computed surface dissolved organic carbon at Station 852

Figure 7-39. Observed and computed bottom dissolved organic carbon at Station 852 
Figure 7-40. Observed and computed surface dissolved oxygen at Station 852

Figure 7-41. Observed and saturated surface dissolved oxygen concentrations at Station 852

Figure 7-42. Modeled and saturated surface dissolved oxygen concentrations at Station 852

Figure 7-43. Observed and computed middepth dissolved oxygen at Station 852

Figure 7-44. Observed and computed bottom dissolved oxygen at Station 852 $7-43$

Figure 7-45. Observed and computed dissolved oxygen profiles at Station 852 for 1995 .

Figure 7-46. Observed and computed dissolved oxygen profiles at Station 852 for 1996 . $7-45$

Figure 7-47. Observed and computed dissolved oxygen profiles at Station 852 for 1997. 7-46

Figure 7-48. Observed and computed surface fecal coliform at Station 852

Figure 7-49. Scatterplot of observed and computed temperature at Lake Washington stations

Figure 7-50. Scatterplot of observed and computed chlorophyll at Lake Washington stations $7-48$

Figure 7-51. Scatterplot of observed and computed total nitrogen at Lake Washington stations

Figure 7-52. Scatterplot of observed and computed nitrate at Lake Washington stations $7-49$

Figure 7-53. Scatterplot of observed and computed ammonium at Lake Washington stations

Figure 7-54. Scatterplot of observed and computed total phosphorus at Lake Washington stations $7-50$

Figure 7-55. Scatterplot of observed and computed ortho-phosphorus at Lake Washington stations $7-50$

Figure 7-56. Scatterplot of observed and computed dissolved oxygen at Lake Washington stations 7-51

Figure 7-57. Relative error in three model applications. 7-51

Figure 8-1. Lake Washington sample stations $8-2$ 
Figure 8-2. Observed and computed net primary production.

Observations are monthly means of reported values.

Daily modeled values are from Station 852 8-3

Figure 8-3. Observed and computed surface respiration.......................... 8-4

Figure 8-4. Observed and computed respiration at 50-m depth ................ 8-4

Figure 8-5. Mean observed and computed respiration at multiple depths

Figure 8-6. Computed carbon deposition and sediment oxygen demand at Station 852

Figure 8-7. Computed particulate and dissolved sediment-water nitrogen flux at Station 852

Figure 8-8. Computed particulate and dissolved sediment-water phosphorus flux at Station 852 . $8-8$

Figure 8-9. Lake Washington model nitrogen budget. Positive fluxes are to the Lake Washington water column. pnfws $=$ particulate nitrogen flux from water to sediment; dnfws $=$ dissolved nitrogen flux at sediment-water interface; tn_flux = transport at Lake Union interface; load = sum of all external loads; and net accumulation = change in water column mass

Figure 8-10. Lake Washington model phosphorus budget. Positive fluxes are to the Lake Washington water column. ppfws $=$ particulate phosphorus flux from water to sediment; benpo $4=$ dissolved phosphorus flux at sediment-water interface; tp_flux = transport at Lake Union interface; load $=$ sum of all external loads; and net accumulation $=$ change in water column mass. 


\section{List of Tables}

Table 1-1 Physical Characteristics of Lakes Washington and Union....... 1-3

Table 2-1 Flows and Loads................................................................... 2-5

Table 2-2 Sources and Splits of Organic Matter....................................... 2-5

Table 2-3 Concentrations in Sewage Overflows …................................ 2-6

Table 2-4 Cedar River Concentrations ................................................. 2-6

Table 2-5 Sammamish River Concentrations ........................................ 2-6

Table 2-6 Thornton Creek Concentrations .............................................. 2-7

Table 2-7 Nitrogen Loads, $\mathrm{kg} \mathrm{day}^{-1}$.................................................... 2-7

Table 2-8 Phosphorus Loads, $\mathrm{kg} \mathrm{day}^{-1}$.............................................. 2-7

Table 2-9 Fecal Coliform Loads, $10^{6}$ organisms day ${ }^{-1}$.......................... 2-7

Table 2-10 Suspended Solids Loads, $\mathrm{kg} \mathrm{day}^{-1}$....................................... 2-8

Table 3-1 Lake Washington Water Quality Model State Variables ......... 3-2

Table 3-2 Parameters in Kinetics Equations ........................................... 3-28

Table 5-1 Sediment Model State Variables and Fluxes............................ 5-2

Table 5-2 Routing Organic Particles into Sediment Classes .................... 5-6

Table 7-1 Observed Constituents........................................................ 7-2

Table 7-2 Summary Statistics …..................................................... 7-11

Table 8-1 Observed Deposition and Sediment-Water Fluxes.................. 8-6

Table 8-2 Model Nutrient Budget, $\mathrm{kg}$ day $^{-1}$.......................................... 8-10

Table 8-3 Model Nutrient Budget Compared to Edmondson and Lehman (1981) .............................................................. 8-10

Table 9-1 Lake Washington Water Quality Model State Variables ......... 9-3

Table 9-2 Sediment Model State Variables and Fluxes........................... 9-3 


\section{Preface}

This study was sponsored by the King County, Washington, Department of Natural Resources and Parks. Project Officer was Mr. Kevin Schock, PE.

This study was conducted by the Water Quality and Contaminant Modeling Branch, Environmental Processes and Effects Division, EL. This report was prepared by Dr. Carl F. Cerco, Mr. Mark R. Noel, and Dr. Sung-Chan Kim, Water Quality and Contaminant Modeling Branch. The study was supervised by Drs. Barry W. Bunch, Chief, Water Quality and Contaminant Modeling Branch, and Richard E. Price, Chief, Environmental Processes and Effects Division, under the general supervision of Dr. Elizabeth C. Fleming, Acting Director, EL.

COL James R. Rowan, EN, was Commander and Executive Director of ERDC. Dr. James R. Houston was Director. 


\section{Introduction}

\section{Lake Washington}

Lake Washington is one of a system of three lakes located in northwestern Washington State (Figure 1-1). The lake provides a textbook example of eutrophication remediation through reduction of nutrient loads. The decline and recovery of the lake are the subject of a series of classic works by W. T. Edmondson, his students, and co-workers (Edmondson 1972; Edmondson and Lehman 1981; Edmondson 1991; Edmondson 1994). The description of the lake in this chapter is derived from these sources as well as from a Web site maintained by the King County Department of Natural Resources and Parks (http://dnr/metrokc.gov/wlr/waterres/lakes/Monitor.htm).

Lake Washington was formed at the end of an ice age roughly 12,000 years ago. Within historic times, the lake had one major inflow at its northern end, the Sammamish River, which drains Lake Sammamish. The outlet was the Black River at the southern end. The Black River flowed into the Cedar River, which led to Puget Sound. In 1916, a locked ship canal was constructed that connected Lake Washington with Puget Sound through Lake Union to the west. The level of Lake Washington was lowered by $3.3 \mathrm{~m}$, and the Cedar River was converted from an outflow to an inflow. The major outflow was now through the Chittenden locks at the western end of Lake Union.

Lake Washington received increasing amounts of sewage effluent from 1941 to 1963. In response, concentrations of nutrients and phytoplankton increased and the nature of the phytoplankton community changed. Between 1963 and 1968, sewage discharge to the lake was eliminated. Concentrations of nutrients and phytoplankton and the proportion of blue-green algae all declined as a result. By 1975, the lake had recovered from its eutrophic state.

Lake Washington is the largest of the three major lakes in King County, and the second largest natural lake in the state of Washington. Lake Washington's two major influent streams are the Cedar River at the southern end, which contributes about 57 percent of the annual runoff, and the Sammamish River at the northern end, which contributes 27 percent of the annual runoff. Total annual flow is approximately 41 percent of the lake volume. Residence time is about 2.4 years. The majority of the immediate watershed (Figure 1-2) is highly developed and urban in nature with 63 percent fully developed. The upper 
portion of the watershed is the headwaters of the Cedar River that lie in the closed Seattle Water Department watershed.

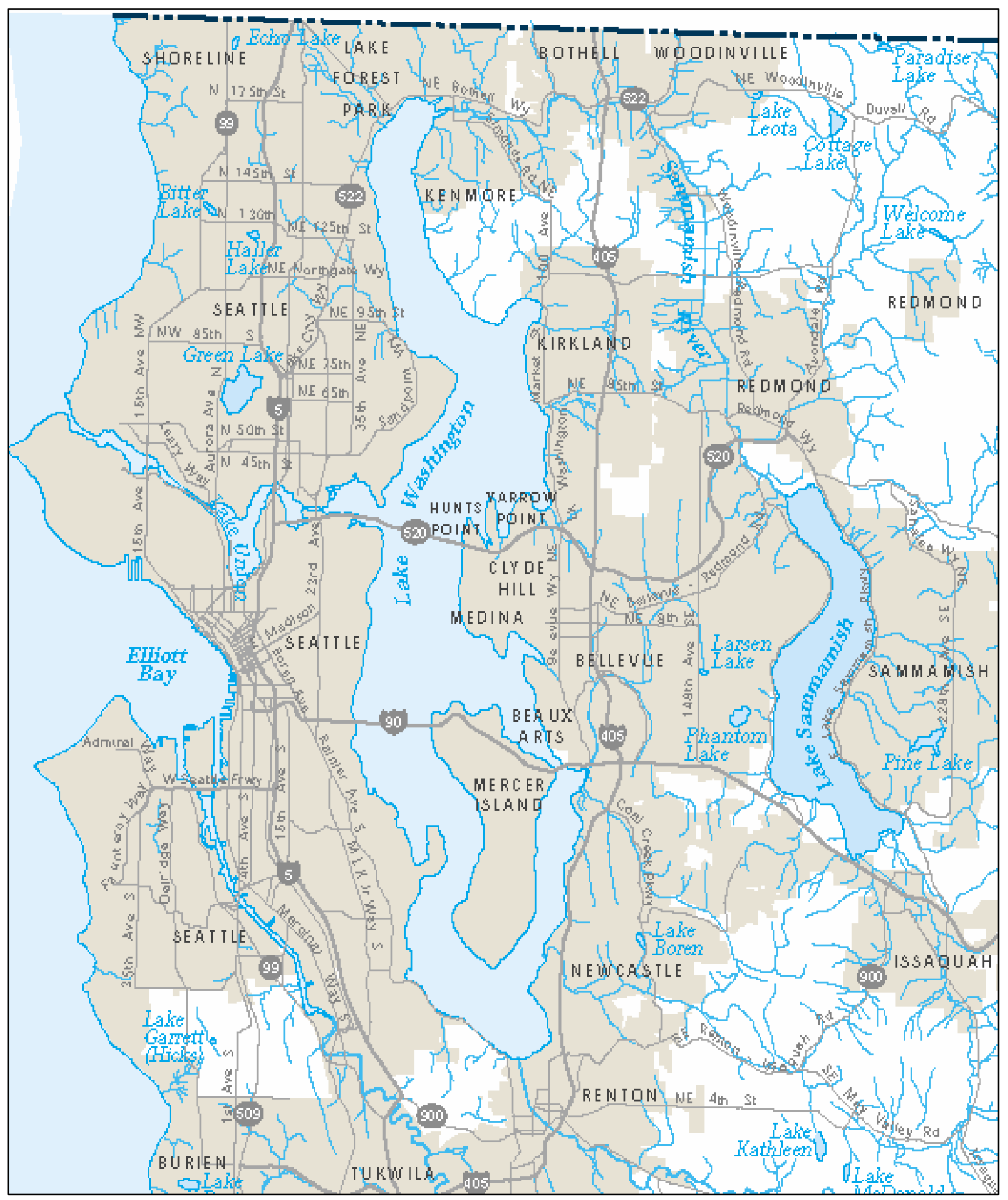

Figure 1-1. Lakes Washington and Union 


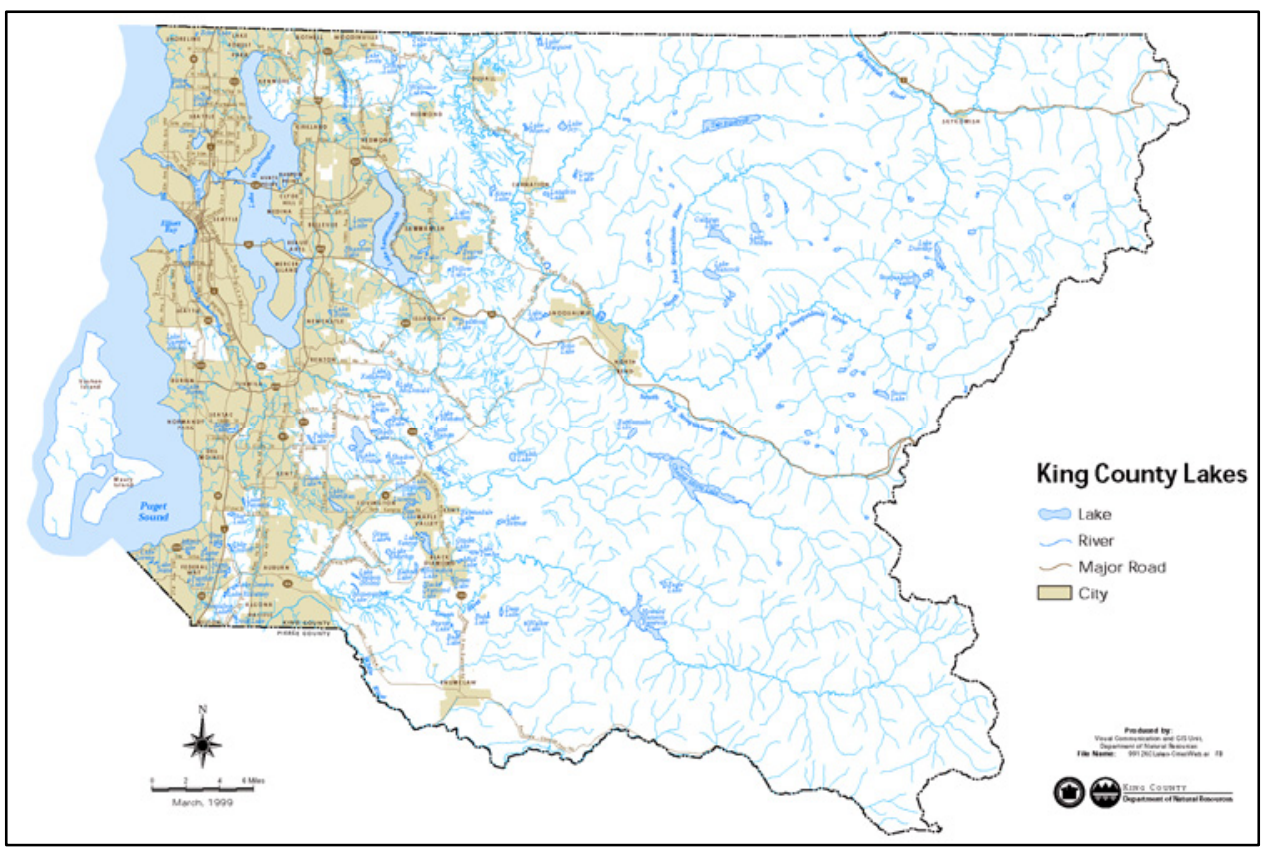

Figure 1-2. Watershed of three lakes

The basin of Lake Washington (Table 1-1) is a deep, narrow, glacial trough with steeply sloping sides, sculpted by the Vashon ice sheet, the last continental glacier to move through the Seattle area. The lake is $6.3 \mathrm{~m}(20.6 \mathrm{ft})$ above mean lower low tide in Puget Sound, to which it is connected via Lake Union and the Lake Washington Ship Canal. Mercer Island lies in the southern half of the lake, separated from the east shore by a relatively shallow and narrow channel, and from the west shore by a much wider and deeper channel.

\section{Table 1-1 \\ Physical Characteristics of Lakes Washington and Union}

\begin{tabular}{||l|l|l||}
\hline \hline Property & Lake Washington & Lake Union \\
\hline \hline Drainage area, $\mathrm{km}^{2}$ & 1,274 & 1,554 \\
\hline Surface area, $\mathrm{km}^{2}$ & 87.6 & 2.3 \\
\hline Volume, $\mathrm{m}^{3}$ & $2 \times 10^{9}$ & $2.5 \times 10^{7}$ \\
\hline Mean depth, $\mathrm{m}$ & 32.9 & 10 \\
\hline Maximum depth, $\mathrm{m}$ & 65.2 & 5 \\
\hline Residence time, years & 2.3 & 0.02 \\
\hline
\end{tabular}

\section{Lake Union}

Lake Union (Table 1-1) was formed by the Vashon glacier about 12,000 years ago. Originally the lake was separated from Lake Washington by the land extending between Portage Bay and Union Bay, and outflow from the lake was through Salmon Bay, which was then a marine inlet. 
In 1914, the hydrology of the lake was significantly altered by the construction of the Fremont and Montlake cuts and the Hiram M. Chittenden Locks. These modifications increased inflow to Lake Union by diverting the outflow from Lake Washington through Lake Union via the Montlake Cut and the Ship Canal. Lake Union now flushes completely about once a week at high water flows. The opening of the Ship Canal allows periodic influx of salt water from Puget Sound. The extent of the saltwater intrusion varies with runoff volume and lock operation. During the rainy season and spring thaw, runoff from the Cascade foothills is high and the lake is flushed with fresh water. As the flow drops off in the summer and boat passage through the lock increases, the intrusion of salt water through the locks increases.

The intrusion of salt water forms a saline wedge that flows up the bottom of the Ship Canal and the lake. The saline bottom water becomes devoid of oxygen early in the summer, as the oxygen is used by bacteria that consume organic matter. The anoxic conditions and warm water temperatures limit the amount of habitat available to fish. The irregular influx of salt water poses an adaptation problem for the benthic organisms that form the basis of the lake's food web. Concern for these effects and the potential for permanent damage to Lake Washington, should a large flow of salt water move that far, prompted the U.S. Army Corps of Engineers in 1964 to build a saltwater siphon at the locks to return some of the salt water to Puget Sound. Beginning in the early 1980's the Corps of Engineers made additional modifications in lock operation to help reduce the saline intrusion and to conserve Lake Washington water used to flush saline water from the locks.

Lake Union is unique among the three local major lakes in the character of its watershed (Figure 1-2). It is the most heavily urbanized of the three, draining residential, commercial, and industrial neighborhoods. Its shores are completely lined by marinas, houseboat moorage, commercial docks and dry docks, and industries. In the past, the lake received sanitary discharges from houseboats and ships and industrial discharges from businesses along the shore, as well as fuel spills and discharges from ships and onshore facilities. While pollution inputs from many of these sources have decreased, not all of these discharges have stopped. Combined-sewer overflows still occur and are generally agreed to be the worst source of pollutants and pathogens to the lake.

\section{Study Objectives}

The King County Water Lands Resources Division and the Wastewater Treatment Division are in the process of developing a predictive tool to assess water quality in the three lakes, the Sammamish River, and their associated watersheds. This model development is being done as part of the SammamishWashington Analysis and Modeling Program (SWAMP). The assessment has many components, but generally the county wants to develop a robust tool to assess various management strategies for water reuse and land use. Part of the assessment tool will be the use of a water quality computer model. The SWAMP modeling work has the following objectives: 
a. Understand existing conditions in the water bodies of the watershed and associated risks to aquatic life, wildlife, and people.

$b$. Understand future conditions in the water bodies of the watershed and potential risks to aquatic life, wildlife, and people under defined "buildout" conditions.

c. Understand the effects of using reclaimed water in the watershed on existing and future conditions and resulting potential risks to aquatic life, wildlife, and people.

In September 2000, the King County Department of Natural Resources and Parks signed a cooperative agreement with the U.S. Army Engineer Research and Development Center (ERDC) to provide the water quality models necessary for the larger SWAMP effort. ERDC responsibilities under the agreement included the following:

a. Configure and execute a model for Lake Washington.

b. Submit written project reports.

c. Provide training and expertise to county personnel.

d. Assist in assessing model operation, interpretation of field data, and model results.

e. Modify code as required.

$f$. Provide expertise on lake and river dynamics such as nutrient dynamics, ecology, and sediment-water interactions.

For the modeling effort, ERDC applied the CH3D-WES hydrodynamic model (Johnson et al. 1993) and the CE-QUAL-ICM eutrophication model (Cerco and Cole 1993). The models were applied to Lakes Washington and Union for the period 1995-1997 with the emphasis on Lake Washington. Lake Union was modeled so that the downstream boundary condition could be located away from the region of greatest interest. The present report comprises the primary documentation of the model effort.

\section{References}

Cerco, C., and Cole, T. (1993). "Three-dimensional eutrophication model of Chesapeake Bay," Journal of Environmental Engineering 119(6), 10061025.

Edmondson, W. (1972). "Nutrients and phytoplankton in Lake Washington." Nutrients and eutrophication: The limiting nutrient controversy. Volume I.

G. E. Likens, ed., American Society of Limnology and Oceanography, Lawrence, KS, 172-93.

Edmondson, W. (1991). The uses of ecology-Lake Washington and beyond. University of Washington Press, Seattle. 
Edmondson, W. (1994). "Sixty years of Lake Washington: A curriculum vitae," Lake and Reservoir Management 10(2), 75-84.

Edmondson, W., and Lehman, J. (1981). "The effect of changes in the nutrient income on the condition of Lake Washington," Limnology and Oceanography 26(1), 1-29.

Johnson, B., Kim, K., Heath, R., Hsieh, B., and Butler, L. (1993). "Validation of a three-dimensional hydrodynamic model of Chesapeake Bay," Journal of Hydraulic Engineering 119(1), 2-20. 


\section{Flows, Loads, and Boundary Conditions}

\section{Flows}

Flows into Lake Washington may be divided into two categories: gauged and distributed. The gauged flows enter at defined locations and are sufficiently large to merit continuous measurement by the United States Geological Survey (USGS). Gauged flows (Figure 2-1) include the Sammamish River near Woodinville (12125200), the Cedar River at Renton (12119000), and Thornton Creek near Seattle (12128000). Daily gauged flows were input to the model at corresponding locations.

The distributed flows enter at undefined locations and are not monitored. The sponsor provided daily distributed flows for 27 basins (Figure 2-2). These were computed based on precipitation and basin characteristics. The distributed flows were pooled into 10 locations (Figure 2-1, Table 2-1) that could be identified as named tributaries or features and input to the model on a daily basis.

Flows into Lake Washington showed typical seasonality. Highest flows occurred from November through March or April (e.g., Figure 2-3). Lowest flows occurred in August or September. During the study period, flow in the Cedar River oscillated around the long-term average in 1995 and 1996 and was above average for much of 1997 (Figure 2-3). Similar behavior was observed in the Sammamish River (Figure 2-4). Thornton Creek exhibited above-average flows for the 1995-1996 wet season and typical flows otherwise (Figure 2-5). The distributed flows showed seasonality consistent with the gauged flows (Figure 2-6). No distinct wet or dry years were apparent.

For the study period, the ranking of flow sources was consistent with statistics reported on the sponsor's Web site http://dnr/metrokc.gov/wlr/waterres/ lakes/Monitor.htm. The Cedar River provided 60 percent of the runoff followed by the Sammamish River with 28 percent. Thornton Creek provided approximately 1 percent and was revealed to be a minor source despite the presence of a USGS gauge. Distributed flows contributed the remaining 11 percent. 


\section{Loads}

Loads of nutrients, organic matter, suspended solids, and pathogens enter Lake Washington from three primary sources: runoff, combined-sewer overflows (CSOs), and atmospheric deposition. Point-source loads from municipal waste were eliminated in the period from 1963 to 1968.

\section{Runoff}

Daily runoff loads were computed as the product of flow and concentration. Concentrations in gauged flows, observed at approximately monthly intervals, were provided by the sponsor. Concentrations were reported for the following:

- Total Nitrogen

- Total Phosphorus

- Total Suspended Solids

- Nitrate+Nitrite Nitrogen

- Ortho-Phosphorus

- Ammonium

- Fecal Coliform

Linear interpolation was used to create daily concentrations from the monthly values. The record for the Cedar River commenced in April 1996. Prior to this date, monthly-average values from the period of record were employed. Daily concentrations were multiplied by daily flows to create a time series of daily loads.

Nitrogen and phosphorus concentrations in distributed flows from each basin were provided by the sponsor. These were obtained from regression relationships based on precipitation and impervious area. Daily concentrations were multiplied by daily flows to create a time series of daily loads. Loads were input at one location for each of the basins. Locations corresponded with locations of distributed flows when these were present.

Fecal coliform concentrations in distributed flows were based on observations provided by the sponsor. Constant values, $\approx 300 \mathrm{mpn} / 100 \mathrm{~mL}$ (where $\mathrm{mpn}=$ most probably number), were employed for each basin. Constant suspended solids concentrations, 5 to $9 \mathrm{~g} \mathrm{~m}^{-3}$, were similarly derived and employed. Consequently, variation in daily loads from each basin reflects variation in flow only.

Organic carbon. A limited quantity of organic carbon observations, collected in 2002, was available for the Cedar and Sammamish Rivers. Mean total organic carbon concentrations were $6.2 \mathrm{~g} \mathrm{~m}^{-3}$ for the Sammamish and $2.4 \mathrm{~g} \mathrm{~m}^{-3}$ for the Cedar.

This situation of limited organic carbon observations is common. Consequently, organic carbon loads for the model are computed as a multiple of organic nitrogen loads. Based on the observations, a carbon-to-nitrogen ratio of 20 was used. 
Mapping to model variables. The model requires loads split into multiple forms of organic carbon, nitrogen, and phosphorus (Table 2-2). Organic nitrogen and phosphorus were estimated as the difference between reported total and mineral forms. The dissolved fraction of organic carbon and nitrogen was derived from the organic carbon observations. The dissolved fraction of organic phosphorus was derived from data reported by Edmondson and Lehman (1981).

\section{Combined-sewer overflows}

Combined-sewer overflows, sanitary-sewer overflows, and spills were reported at 28 locations (Figure 2-7) during the study period. Daily flow volume for each incident was provided by the sponsor. The sponsor also provided characteristic concentrations for the discharges (Table 2-3). Concentrations in CSOs were based on median concentrations observed in the Landers CSO. Concentrations in the sanitary-sewer overflows and spills were based on median concentrations in the West Point Sewage Treatment Plant influent. Daily loads were computed as the product of flow and concentration and input to the model at appropriate locations. All organic substances were split 25 percent dissolved, 50 percent labile particulate, and 25 percent refractory particulate. Flows were considered negligible relative to runoff volume and were not included in the model.

\section{Atmospheric deposition}

Atmospheric loads were obtained from Edmondson and Lehman (1981). Their mean annual loads were converted to daily areal loads for input to the model. Total nitrogen loading of $1.08 \mathrm{mg} \mathrm{m}^{-2} \mathrm{day}^{-1}$ was split into 50 percent nitrate, 46 percent dissolved organic nitrogen, and 4 percent ammonium. Total phosphorus loading of $0.27 \mathrm{mg} \mathrm{m}^{-2}$ day $^{-1}$ was split into equal portions of phosphate and dissolved organic phosphorus.

\section{Load summary}

Nitrogen and phosphorus. Time series of nitrogen (Figures 2-8 through 2-11) and phosphorus (Figures 2-13 through 2-16) loads corresponded closely with time series of flow (Figures 2-3 through 2-6). The correspondence of flow and load indicated little dependence of concentration on flow. The general lack of correspondence between flow and concentration was previously noted by Edmondson and Lehman (1981). Nitrate was the predominant component of the nitrogen load while phosphate composed less than half the phosphorus load.

The ranking of loads from various runoff sources did not follow the ranking of flows. The Sammamish River was the predominant nutrient source (Table 2-7) even though flow was higher in the Cedar. The proportion of nutrient loads from distributed sources, 18 percent to 25 percent, exceeded the proportion of runoff from distributed sources, 11 percent. The Sammamish contributed greater loads because this river was nutrient-enriched relative to the Cedar (Tables 2-4, 2-5). Nutrient concentrations in distributed loads, as exemplified by Thornton Creek (Table 2-6), were enriched relative to both large rivers. 
An enormous CSO event occurred at the end of 1996 and extended into 1997 (Figures 2-12, 2-17). Loads from this event were comparable to the highest daily loading from major runoff sources. The event was unique to the study period. Other overflows and spills were of much less magnitude and, on an annual basis, loads from these sources were minor relative to major runoff sources (Tables 2-7, 2-8).

Atmospheric deposition was a minor component of the annual total nitrogen budget. Atmospheric phosphorus deposition was less than major runoff sources but comprised a potentially significant load, especially during periods of low runoff.

Fecal coliform. Fecal coliform loads in runoff (Figures 2-18 through 2-22) showed less temporal correspondence to flows than did nutrient loads. Loads in the Cedar were "spiky" with multiple peaks throughout the study period (Figure 2-18) while loads in the Sammamish were dominated by two events that occurred in late 1995 and in late 1996 (Figure 2-19). On an annual basis, the major loads were from the Sammamish and Cedar, followed by distributed loads (Table 2-9). CSO loads included several events that rivaled loads from major runoff sources (Figure 2-22), but spills and overflows were minor sources on a long-term basis (Table 2-9).

Suspended solids. As with nutrients, the time series of suspended solids in major runoff sources corresponded with flows (Figures 2-23 through 2-27). Suspended solids concentrations in the Cedar (Table 2-4) exceeded the Sammamish (Table 2-5) so that the Cedar was the dominant source to the system (Table 2-10). Distributed sources, exemplified by Thornton Creek (Table 2-6), were enriched with solids relative to major runoff sources; but the role of distributed solids sources (Table 2-10) was less than distributed nutrient sources. The late 1996-early 1997 CSO event (Figure 2-27) produced solids loads that rivaled the major rivers; but overflows and spills were a minor component of the long-term suspended solids budget (Table 2-10).

\section{Reference}

Edmondson, W. T., and Lehman, J. (1981). "The effect of changes in the nutrient income on the condition of Lake Washington," Limnology and Oceanography 26(1), 1-29. 


\begin{tabular}{|c|c|c|c|}
\hline \multicolumn{4}{|c|}{$\begin{array}{l}\text { Table 2-1 } \\
\text { Flows and Loads }\end{array}$} \\
\hline Source & Type & Inflow Location & Load \\
\hline Sammamish River & \multirow[t]{3}{*}{ Gauged } & Yes & \multirow{3}{*}{$\begin{array}{l}\text { Observed flow } \times \text { interpolated } \\
\text { concentration }\end{array}$} \\
\hline Cedar River & & Yes & \\
\hline Thornton Creek & & Yes & \\
\hline Lyons & \multirow[t]{27}{*}{ Distributed } & Yes, combined with & \multirow{27}{*}{$\begin{array}{l}\text { Computed flow } \times \text { computed } \\
\text { concentration }\end{array}$} \\
\hline McAleer & & & \\
\hline Lake Park Shore & & No & \\
\hline Magnuson Park & & No & \\
\hline Ravenna & & No & \\
\hline Arboretum & & No & \\
\hline Madison Park & & No & \\
\hline Ranier-Genesee & & No & \\
\hline Seward Park & & No & \\
\hline Lakeridge & & No & \\
\hline Finn-Ken & & \multirow{2}{*}{$\begin{array}{l}\text { Yes, combined with } \\
\text { Juanita }\end{array}$} & \\
\hline Juanita & & & \\
\hline Forbes & & \multirow{2}{*}{$\begin{array}{l}\text { Yes, combined with } \\
\text { Kirkland }\end{array}$} & \\
\hline Kirkland Shores & & & \\
\hline Yarrow Bay & & \multirow{2}{*}{$\begin{array}{l}\text { Yes, combined with Cozy } \\
\text { Cove }\end{array}$} & \\
\hline Cozy Cove & & & \\
\hline Fairweather & & \multirow{2}{*}{$\begin{array}{l}\text { Yes, combined with } \\
\text { Meydenbaur }\end{array}$} & \\
\hline Meydenbaur & & & \\
\hline $\begin{array}{l}\text { South of } \\
\text { Evergreen Pt. }\end{array}$ & & No & \\
\hline Kelsey-Mercer & & Yes & \\
\hline Chism Beach & & No & \\
\hline West Mercer & & Yes & \\
\hline Coal Creek & & Yes & \\
\hline May Creek & & Yes, combined with & \\
\hline Pleasure Pt. & & Pleasure Pt. & \\
\hline Coulon Park & & $\begin{array}{l}\text { Yes, combined with } \\
\text { Cedar River }\end{array}$ & \\
\hline East Mercer Island & & No & \\
\hline
\end{tabular}

\begin{tabular}{|c|c|c|}
\hline \multicolumn{3}{|c|}{$\begin{array}{l}\text { Table } 2-2 \\
\text { Sources and Splits of Organic Matter }\end{array}$} \\
\hline Organic & Obtained from & Split into \\
\hline \multirow[t]{3}{*}{ Carbon } & \multirow[t]{3}{*}{ Organic nitrogen $\times 20$} & 85 percent dissolved \\
\hline & & 7.5 percent labile particulate \\
\hline & & 7.5 percent refractory particulate \\
\hline \multirow[t]{3}{*}{ Nitrogen } & \multirow[t]{3}{*}{ Total nitrogen minus nitrate minus ammonium } & 85 percent dissolved \\
\hline & & 7.5 percent labile particulate \\
\hline & & 7.5 percent refractory particulate \\
\hline \multirow[t]{3}{*}{ Phosphorus } & \multirow[t]{3}{*}{ Total phosphorus minus phosphate } & 10 percent dissolved \\
\hline & & 45 percent labile particulate \\
\hline & & 45 percent refractory particulate \\
\hline
\end{tabular}




\begin{tabular}{|c|c|c|c|c|c|c|c|c|}
\hline \multicolumn{9}{|c|}{$\begin{array}{l}\text { Table } 2-3 \\
\text { Concentrations in Sewage Overflows }\end{array}$} \\
\hline $\begin{array}{l}\text { Type of } \\
\text { Overflow }\end{array}$ & $\begin{array}{l}\mathrm{NO}_{23} \\
\mathrm{~g} \mathrm{~m}^{-3}\end{array}$ & $\begin{array}{l}\mathrm{NH}_{4} \\
\mathrm{~g} \mathrm{~m}^{-3}\end{array}$ & $\begin{array}{l}\text { Total N, } \\
\mathrm{g} \mathrm{m}^{-3}\end{array}$ & $\begin{array}{l}\text { Phosphate, } \\
\mathrm{g} \mathrm{m}^{-3}\end{array}$ & $\begin{array}{l}\text { Total P, } \\
\text { g m}^{-3}\end{array}$ & $\begin{array}{l}\text { Total } \\
\text { Organic } \\
\text { Carbon, } \\
\mathrm{g} \mathrm{m}^{-3}\end{array}$ & $\begin{array}{l}\text { Total } \\
\text { Suspended } \\
\text { Solids (TSS), } \\
\mathrm{g} \mathrm{m}^{-3}\end{array}$ & $\begin{array}{l}\text { Fecal } \\
\text { Coliform, } \\
\text { mpn/100 mL }\end{array}$ \\
\hline $\begin{array}{l}\text { Combined } \\
\text { Sewers }\end{array}$ & "0.51 & 1.1 & 2.58 & 0.1 & 0.42 & 10.2 & 22.9 & 24,000 \\
\hline $\begin{array}{l}\text { Sanitary } \\
\text { Sewers }\end{array}$ & 0.51 & 8.95 & 20.7 & 2.22 & 2.85 & 40 & 130 & 24,000 \\
\hline
\end{tabular}

\begin{tabular}{|c|c|c|c|c|c|c|c|}
\hline \multicolumn{8}{|c|}{$\begin{array}{l}\text { Table } 2-4 \\
\text { Cedar River Concentrations }\end{array}$} \\
\hline Concentration & $\begin{array}{l}\text { Total } N \text {, } \\
\mathrm{g} \mathrm{m}^{-3}\end{array}$ & $\begin{array}{l}\mathrm{NO}_{3} \\
\mathrm{~g} \mathrm{~m}^{-3}\end{array}$ & $\begin{array}{l}\mathrm{NH}_{4} \\
\mathrm{~g} \mathrm{~m}^{-3}\end{array}$ & $\begin{array}{l}\text { Total } P, \\
\mathrm{~g} \mathrm{~m}^{-3}\end{array}$ & $\begin{array}{l}\mathrm{PO}_{4} \\
\mathrm{~g} \mathrm{~m}^{-3}\end{array}$ & $\begin{array}{l}\text { Fecal Coliform, } \\
\mathrm{mpn} / 100 \mathrm{~mL}\end{array}$ & $\begin{array}{l}\text { TSS, } \\
\mathrm{g} \mathrm{m}^{-3}\end{array}$ \\
\hline Mean & 0.42 & 0.27 & 0.030 & 0.036 & 0.011 & 255 & 11.9 \\
\hline Median & 0.38 & 0.25 & 0.028 & 0.024 & 0.008 & 110 & 5.1 \\
\hline Max & 1.12 & 0.62 & 0.071 & 0.199 & 0.061 & 2900 & 57.2 \\
\hline Min & 0.20 & 0.13 & 0.010 & 0.008 & 0.003 & 2 & 1.5 \\
\hline Stdev & 0.20 & 0.10 & 0.014 & 0.033 & 0.011 & 514 & 14.5 \\
\hline $\mathrm{N}$ & 41 & 41 & 30 & 40 & 41 & 39 & 41 \\
\hline
\end{tabular}

\begin{tabular}{|c|c|c|c|c|c|c|c|}
\hline \multicolumn{8}{|c|}{$\begin{array}{l}\text { Table 2-5 } \\
\text { Sammamish River Concentrations }\end{array}$} \\
\hline Concentration & $\begin{array}{l}\text { Total } \mathbf{N} \\
\mathrm{g} \mathrm{m}^{-3}\end{array}$ & $\begin{array}{l}\mathrm{NO}_{3} \\
\mathrm{~g} \mathrm{~m}^{-3}\end{array}$ & $\begin{array}{l}\mathrm{NH}_{4} \\
\mathrm{~g} \mathrm{~m}^{-3}\end{array}$ & $\begin{array}{l}\text { Total } P \text {, } \\
\text { g m}^{-3}\end{array}$ & $\begin{array}{l}\mathrm{PO}_{4} \\
\mathrm{~g} \mathrm{~m}^{-3}\end{array}$ & $\begin{array}{l}\text { Fecal Coliform, } \\
\mathrm{mpn} / 100 \mathrm{~mL}\end{array}$ & $\begin{array}{l}\text { TSS, } \\
\mathrm{g} \mathrm{m}^{-3}\end{array}$ \\
\hline Mean & 0.86 & 0.52 & 0.042 & 0.057 & 0.023 & 286 & 6.3 \\
\hline Median & 0.81 & 0.45 & 0.038 & 0.054 & 0.022 & 205 & 4.9 \\
\hline Max & 1.49 & 0.97 & 0.092 & 0.157 & 0.044 & 3200 & 44.9 \\
\hline Min & 0.57 & 0.21 & 0.018 & 0.032 & 0.010 & 27 & 1.6 \\
\hline Stdev & 0.22 & 0.18 & 0.019 & 0.022 & 0.009 & 468 & 6.5 \\
\hline$N$ & 48 & 48 & 44 & 48 & 48 & 50 & 48 \\
\hline
\end{tabular}




\begin{tabular}{|c|c|c|c|c|c|c|c|}
\hline \multicolumn{8}{|c|}{$\begin{array}{l}\text { Table 2-6 } \\
\text { Thornton Creek Concentrations }\end{array}$} \\
\hline Concentration & $\begin{array}{l}\text { Total } \mathbf{N}, \\
\mathrm{g} \mathrm{m}^{-3}\end{array}$ & $\begin{array}{l}\mathrm{NO}_{3} \\
\mathrm{~g} \mathrm{~m}^{-3}\end{array}$ & $\begin{array}{l}\mathrm{NH}_{4} \\
\mathrm{~g} \mathrm{~m}^{-3}\end{array}$ & $\begin{array}{l}\text { Total P, } \\
\mathrm{g} \mathrm{m}^{-3}\end{array}$ & $\begin{array}{l}\mathrm{PO}_{4} \\
\mathrm{~g} \mathrm{~m}^{-3}\end{array}$ & $\begin{array}{l}\text { Fecal Coliform, } \\
\mathrm{mpn} / 100 \mathrm{~mL}\end{array}$ & $\begin{array}{l}\text { TSS, } \\
\mathrm{g} \mathrm{m}^{-3}\end{array}$ \\
\hline Mean & 1.46 & 1.14 & 0.048 & 0.106 & 0.040 & 1782 & 23.4 \\
\hline Median & 1.50 & 1.29 & 0.048 & 0.080 & 0.035 & 780 & 7.0 \\
\hline Max & 2.28 & 2.03 & 0.113 & 0.340 & 0.101 & 7900 & 170.0 \\
\hline Min & 0.82 & 0.36 & 0.020 & 0.007 & 0.014 & 150 & 1.3 \\
\hline Stdev & 0.30 & 0.41 & 0.023 & 0.074 & 0.021 & 2011 & 38.1 \\
\hline $\mathrm{N}$ & 48 & 48 & 45 & 48 & 48 & 48 & 48 \\
\hline
\end{tabular}

\begin{tabular}{|c|c|c|c|c|}
\hline \multicolumn{5}{|c|}{$\begin{array}{l}\text { Table } 2-7 \\
\text { Nitrogen Loads, kg day }{ }^{-1}\end{array}$} \\
\hline Source & 1995 & 1996 & 1997 & Fraction \\
\hline Cedar & 709 & 841 & 1031 & 28.4 \\
\hline Sammamish & 1092 & 1354 & 1308 & 41.3 \\
\hline Thornton & 55 & 66 & 44 & 1.8 \\
\hline Distributed & 614 & 894 & 760 & 24.9 \\
\hline $\mathrm{CSO}$ & 2 & 33 & 11 & 0.5 \\
\hline Atmospheric & 95 & 95 & 95 & 3.1 \\
\hline
\end{tabular}

\section{Table 2-8}

Phosphorus Loads, kg day $^{-1}$

\begin{tabular}{||l|l|l|l|l||}
\hline \hline Source & $\mathbf{1 9 9 5}$ & $\mathbf{1 9 9 6}$ & $\mathbf{1 9 9 7}$ & Fraction \\
\hline \hline Cedar & 42.0 & 62.5 & 85.9 & 30.5 \\
\hline Sammamish & 82.1 & 76.7 & 68.8 & 36.5 \\
\hline Thornton & 4.0 & 3.0 & 3.1 & 1.6 \\
\hline Distributed & 33.0 & 43.6 & 38.3 & 18.4 \\
\hline CSO & 0.4 & 4.8 & 1.7 & 1.1 \\
\hline Atmospheric & 24.7 & 24.7 & 24.7 & 11.9 \\
\hline \hline
\end{tabular}

\begin{tabular}{|c|c|c|c|c|}
\hline \multicolumn{5}{|c|}{$\begin{array}{l}\text { Table } 2-9 \\
\text { Fecal Coliform Loads, } 10^{6} \text { organisms day }{ }^{-1}\end{array}$} \\
\hline Source & 1995 & 1996 & 1997 & Fraction \\
\hline Cedar & $1,820,638$ & $1,960,678$ & $5,110,896$ & 31.2 \\
\hline Sammamish & $4,662,155$ & $5,538,131$ & $1,589,455$ & 41.4 \\
\hline Thornton & 579,672 & 356,444 & 475,251 & 5.0 \\
\hline Distributed & $1,229,815$ & $1,689,904$ & $1,501,836$ & 15.5 \\
\hline $\mathrm{CSO}$ & 218,180 & $1,202,159$ & 548,756 & 6.9 \\
\hline
\end{tabular}




\begin{tabular}{|c|c|c|c|c|}
\hline \multicolumn{5}{|c|}{$\begin{array}{l}\text { Table } 2-10 \\
\text { Suspended Solids Loads, kg day }{ }^{-1}\end{array}$} \\
\hline Source & 1995 & 1996 & 1997 & Fraction \\
\hline Cedar & 12684 & 19520 & 23553 & 53.7 \\
\hline Sammamish & 15484 & 11717 & 9315 & 35.2 \\
\hline Thornton & 1174 & 484 & 558 & 2.1 \\
\hline Distributed & 2484 & 3443 & 3038 & 8.6 \\
\hline $\mathrm{csO}$ & 21 & 235 & 83 & 0.3 \\
\hline
\end{tabular}

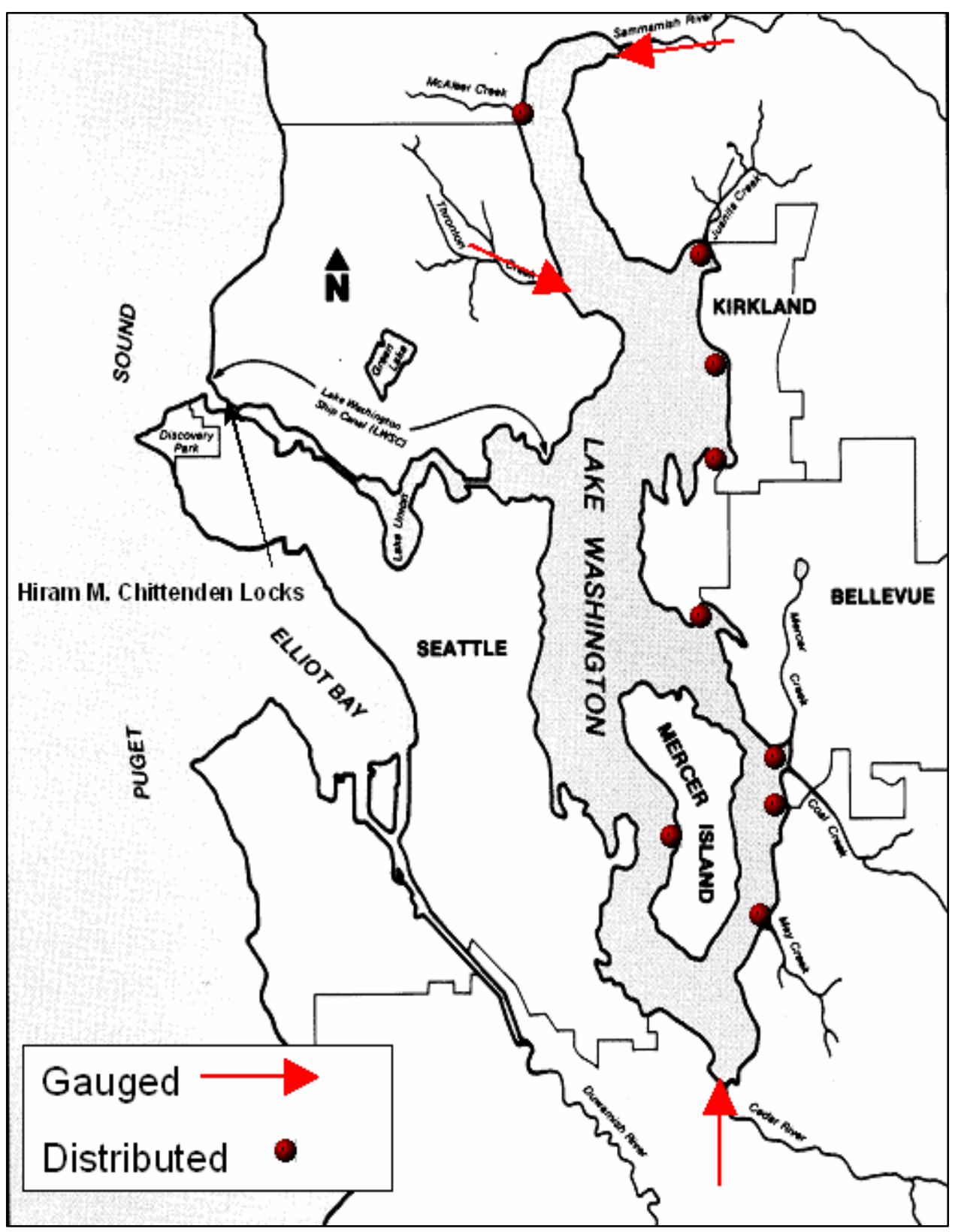

Figure 2-1. Locations of gauged and distributed flows 


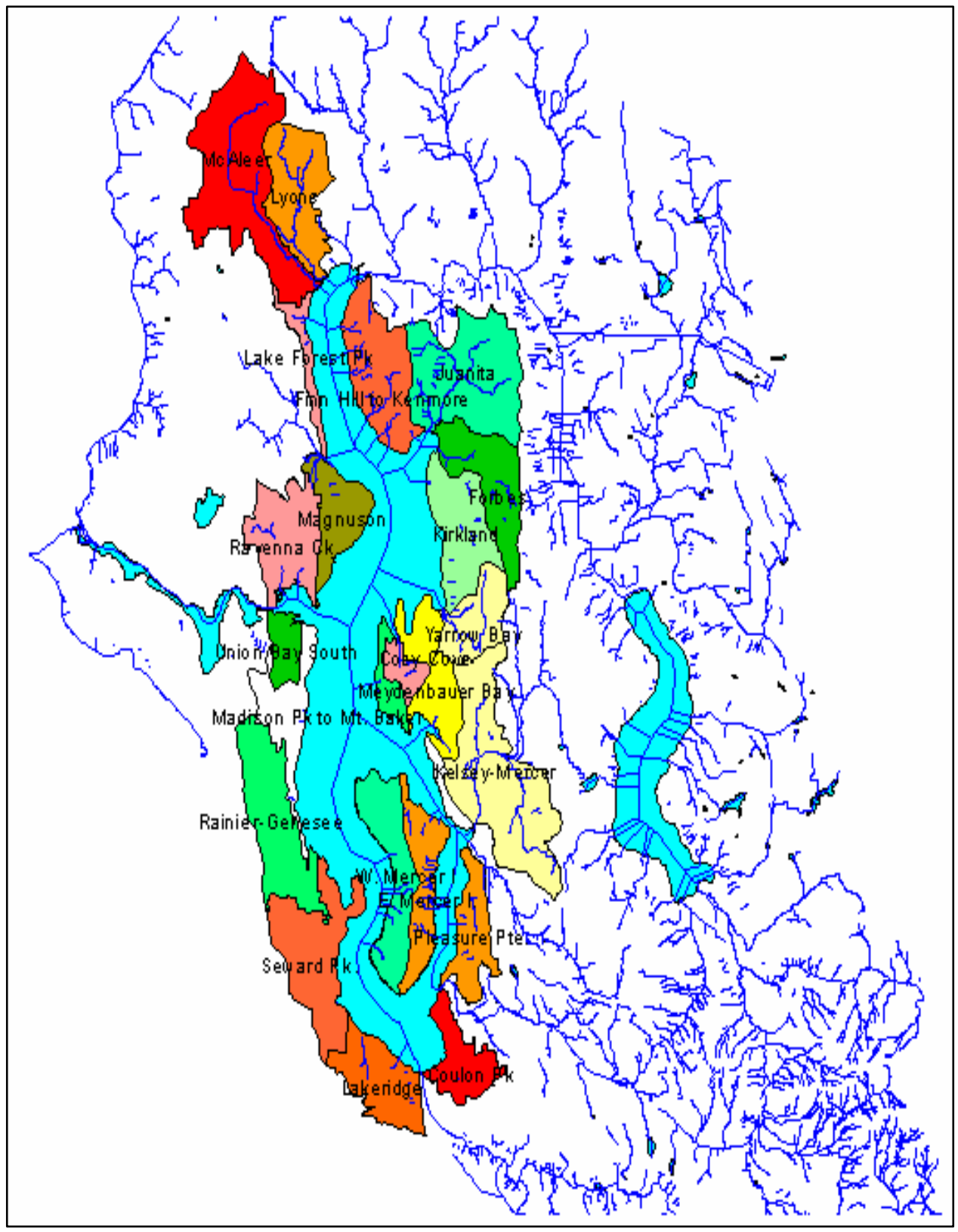

Figure 2-2. Distributed flow basins 


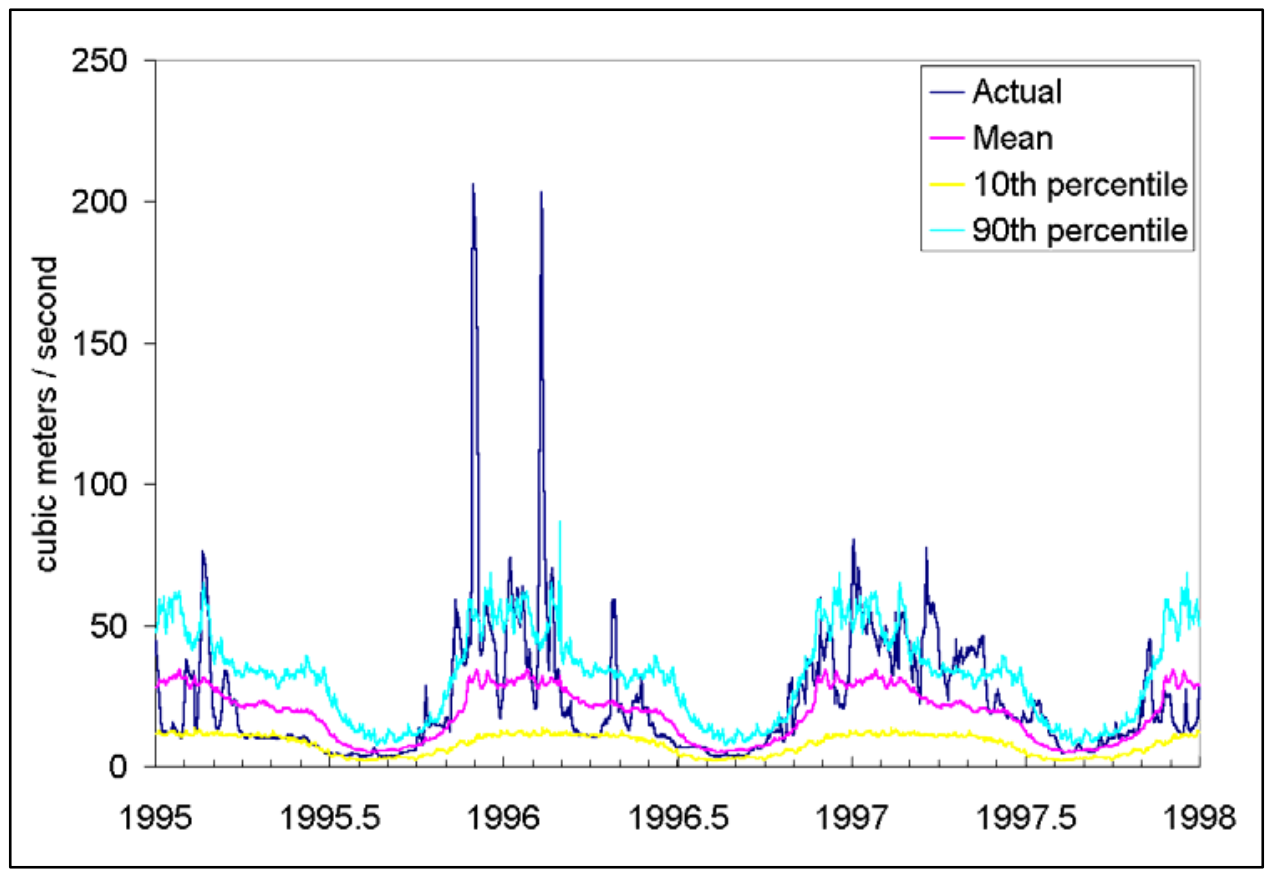

Figure 2-3. Flow in Cedar River

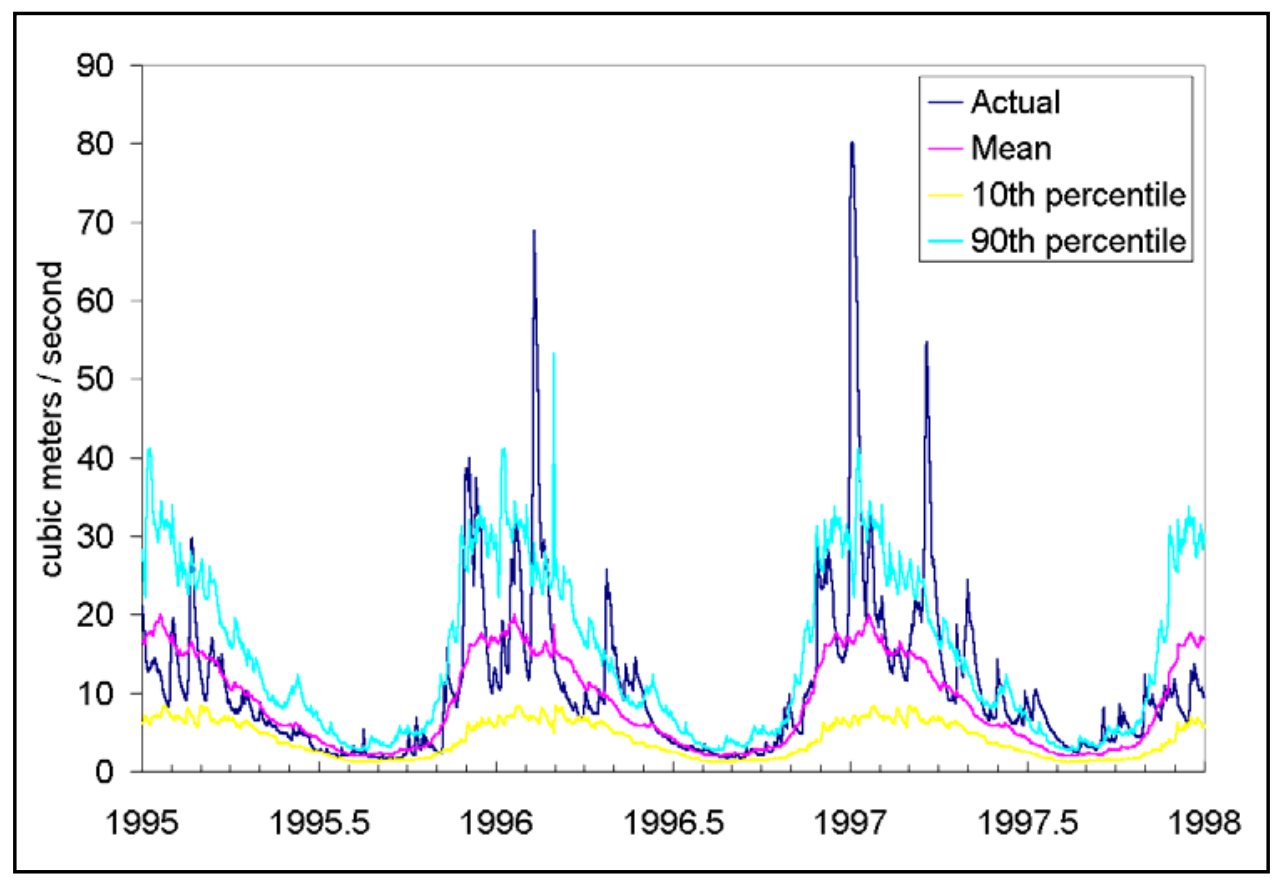

Figure 2-4. Flow in Sammamish River 


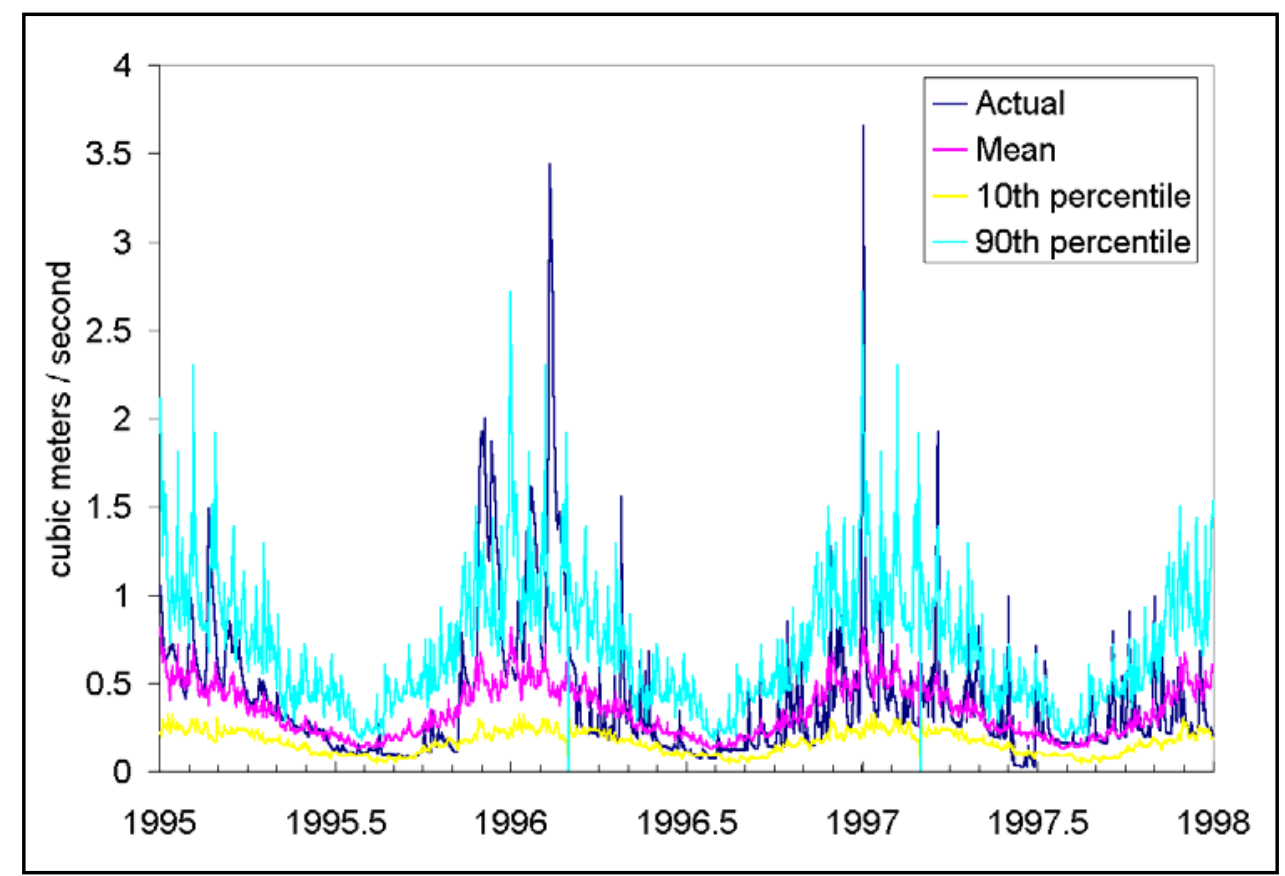

Figure 2-5. Flow in Thornton Creek

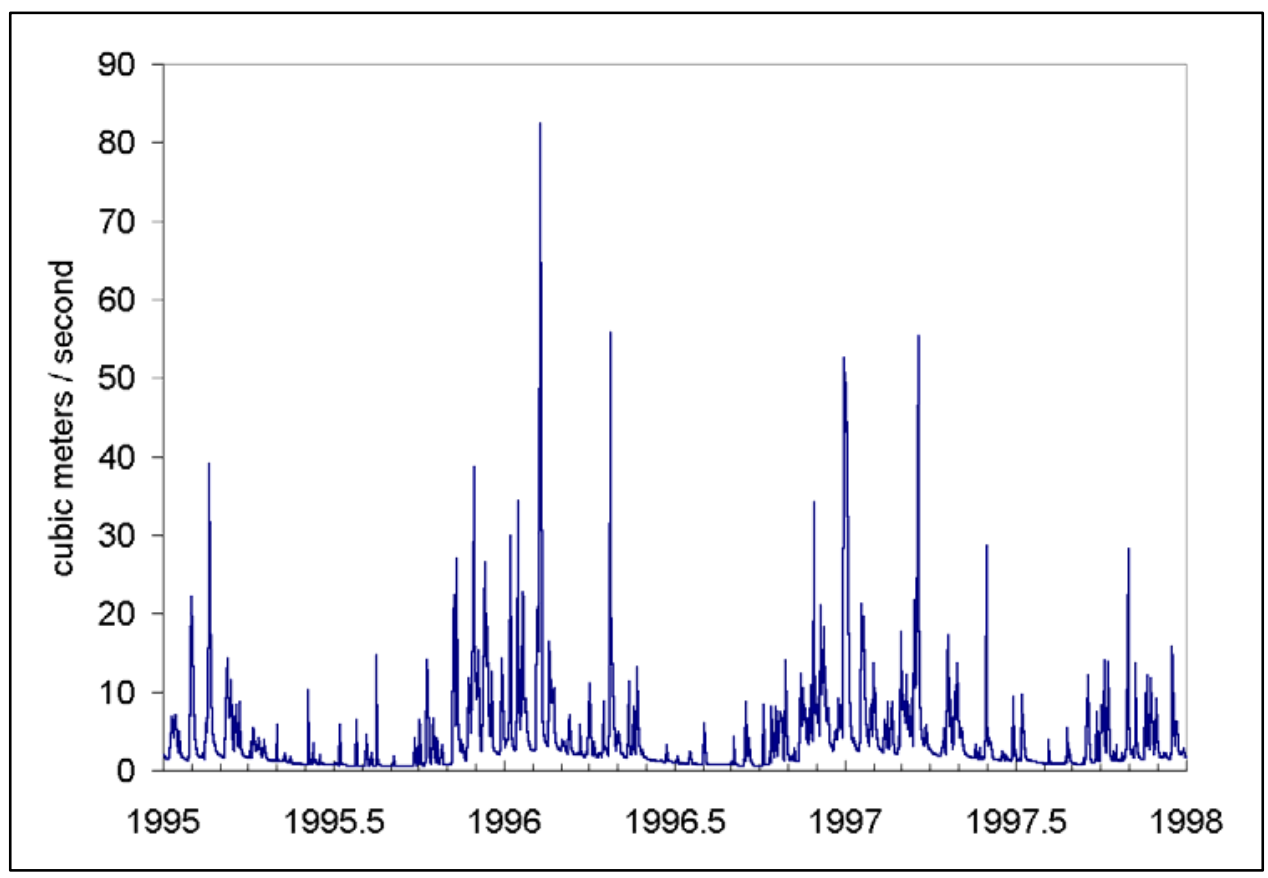

Figure 2-6. Distributed flows 


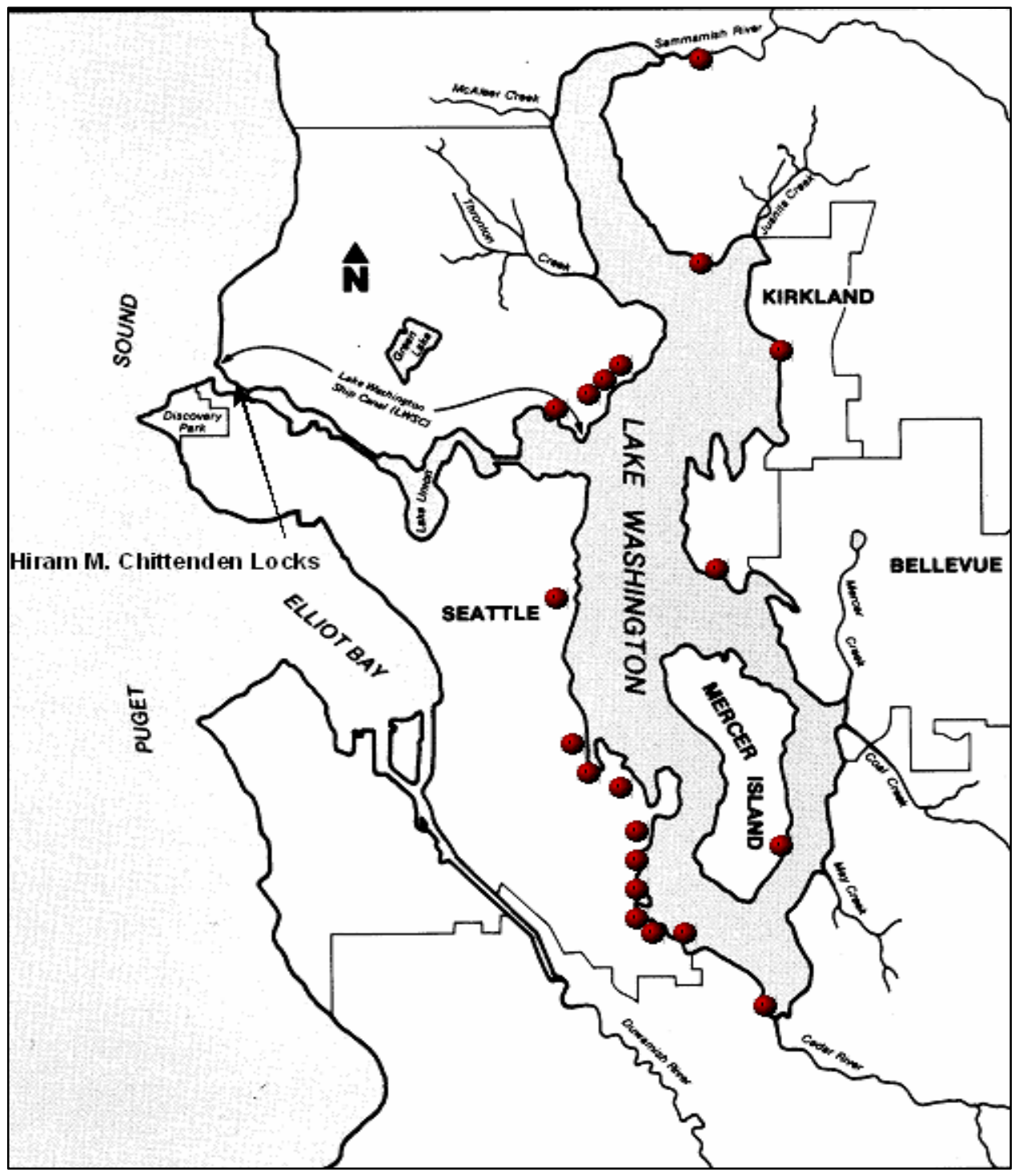

Figure 2-7. Location of sewer overflows and spills 


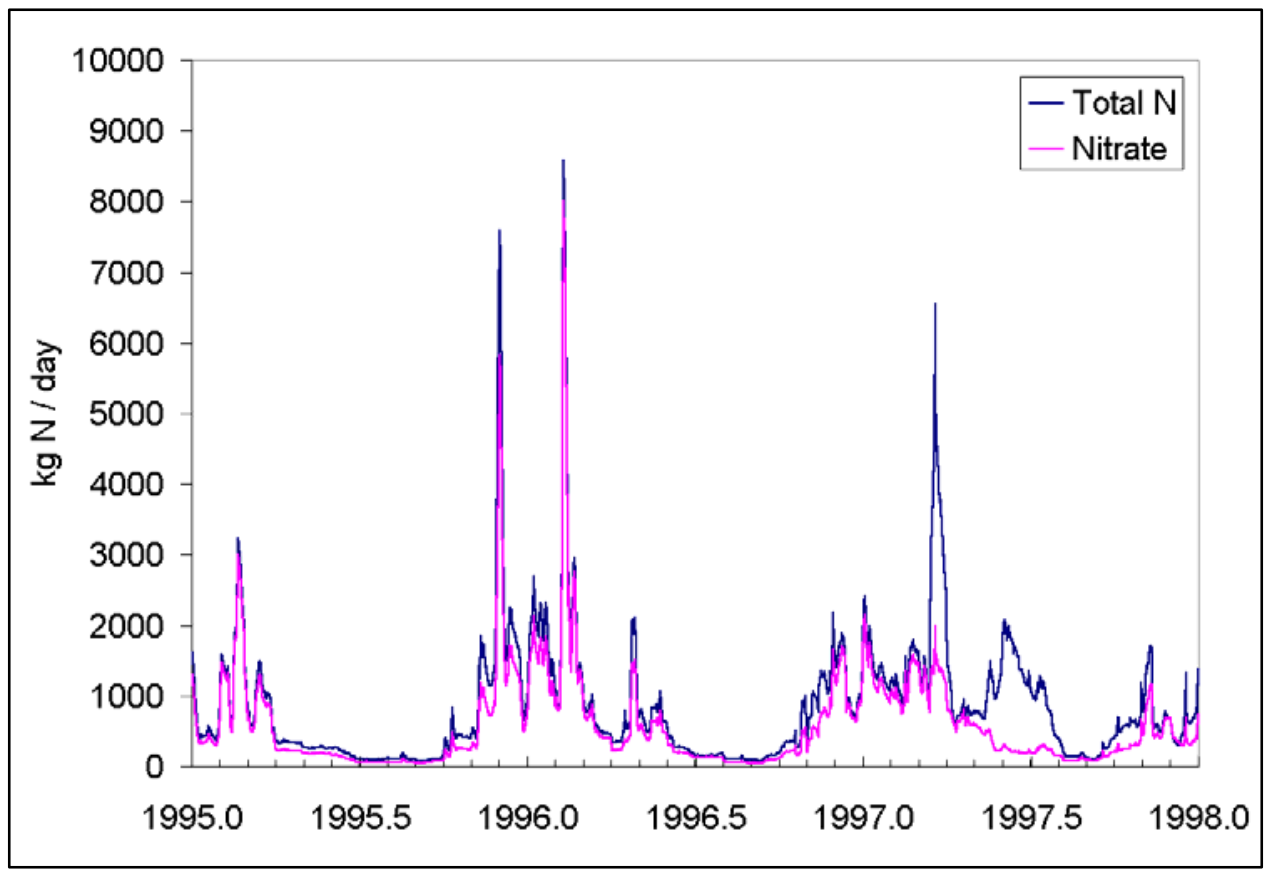

Figure 2-8. Daily nitrogen load from Cedar River

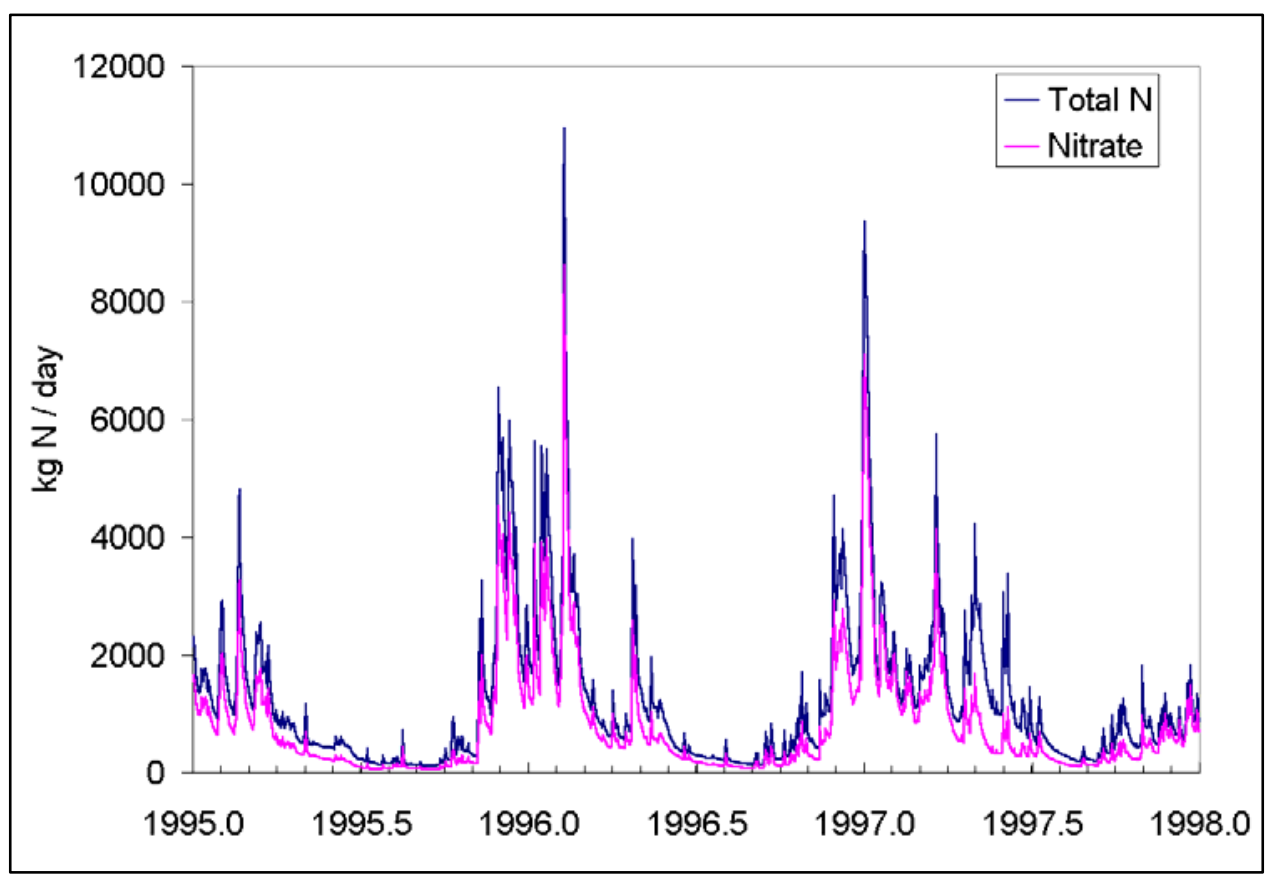

Figure 2-9. Daily nitrogen load from Sammamish River 


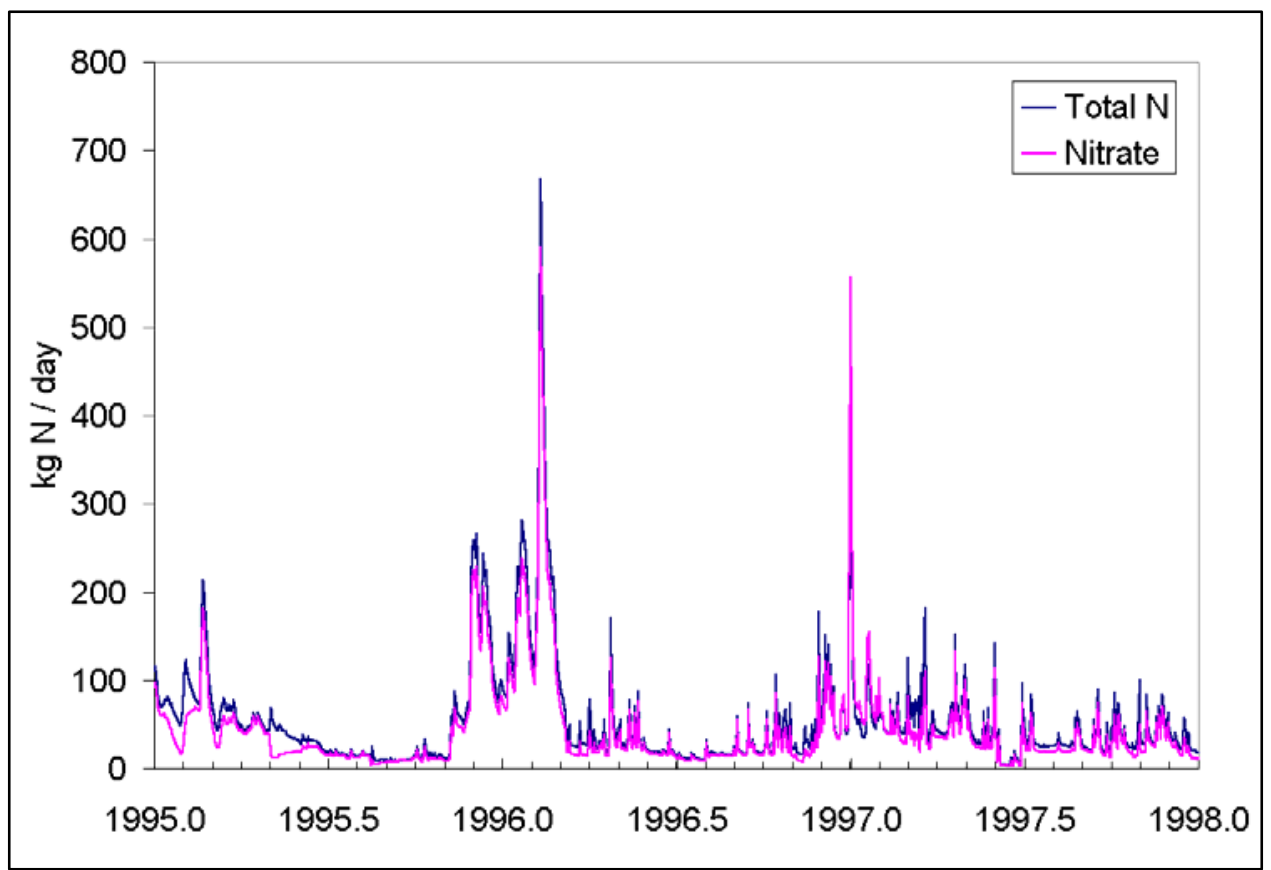

Figure 2-10. Daily nitrogen load from Thornton Creek

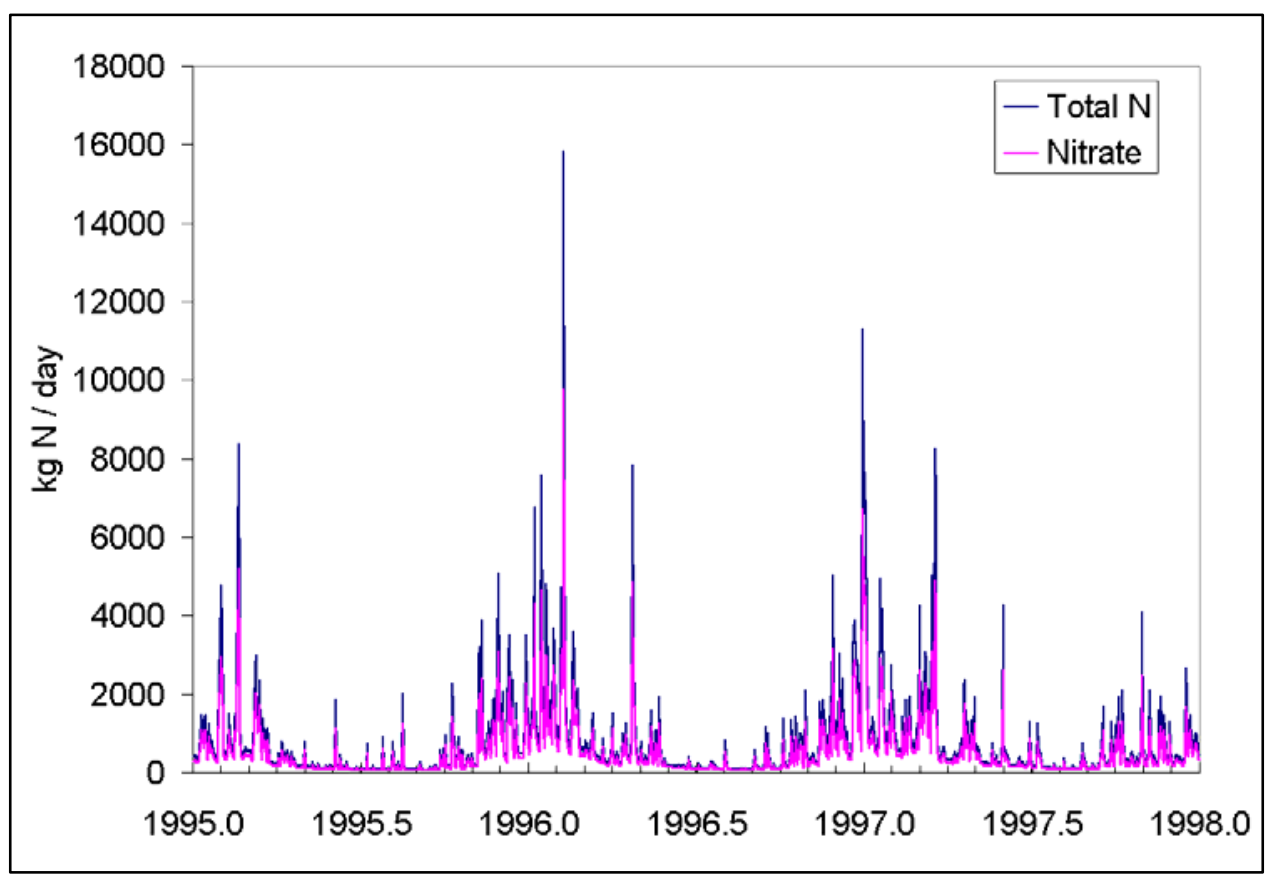

Figure 2-11. Daily nitrogen load from distributed sources 


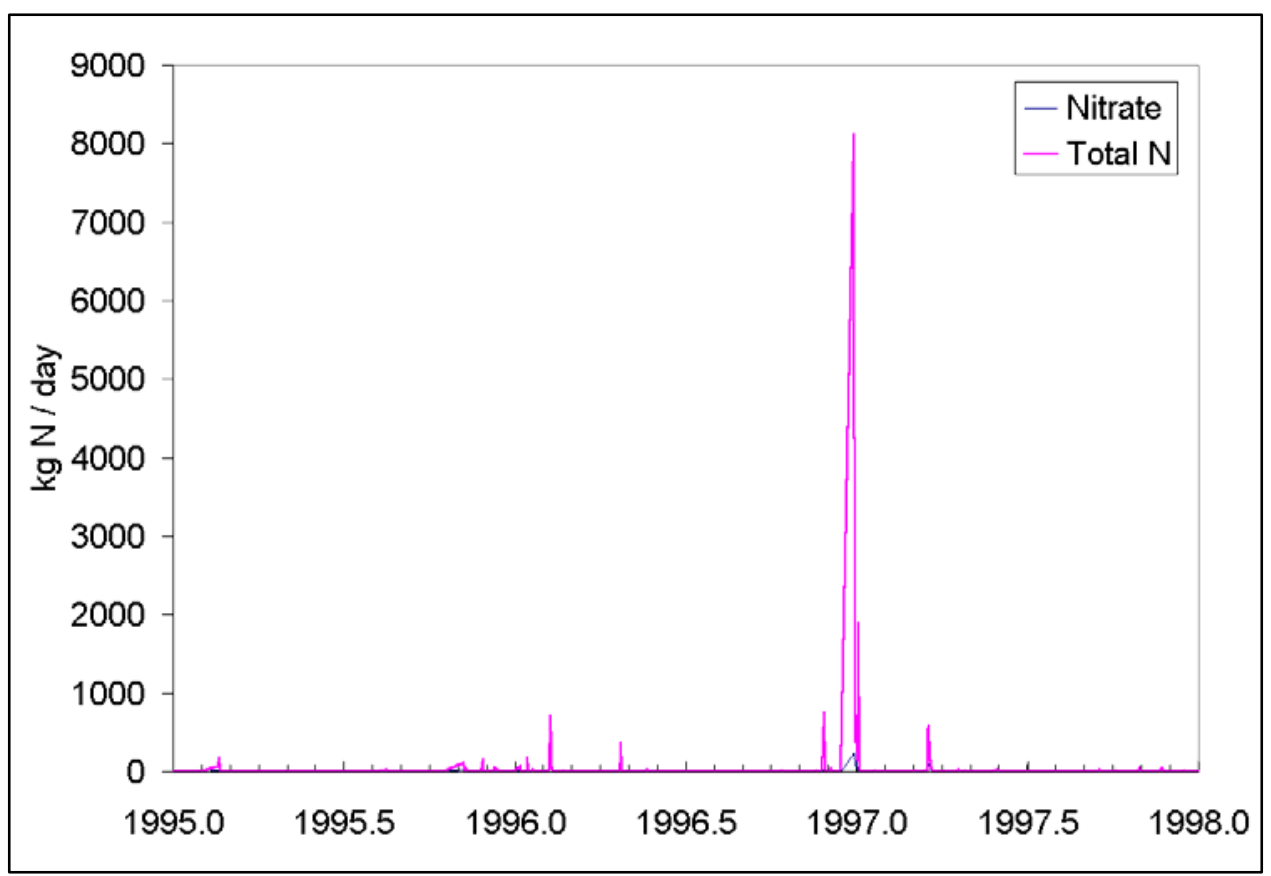

Figure 2-12. Daily nitrogen load from sewer overflows and spills

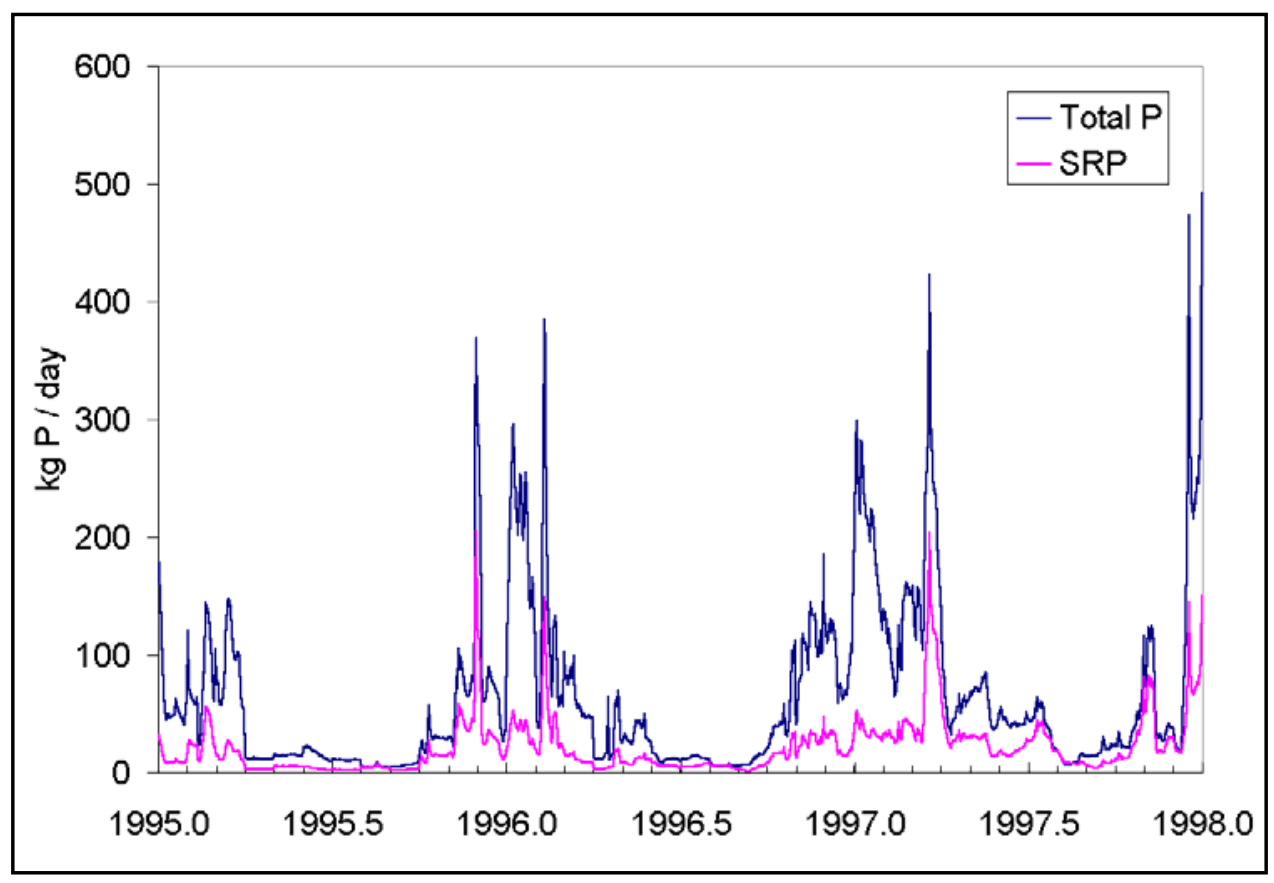

Figure 2-13. Daily phosphorus load from Cedar River 


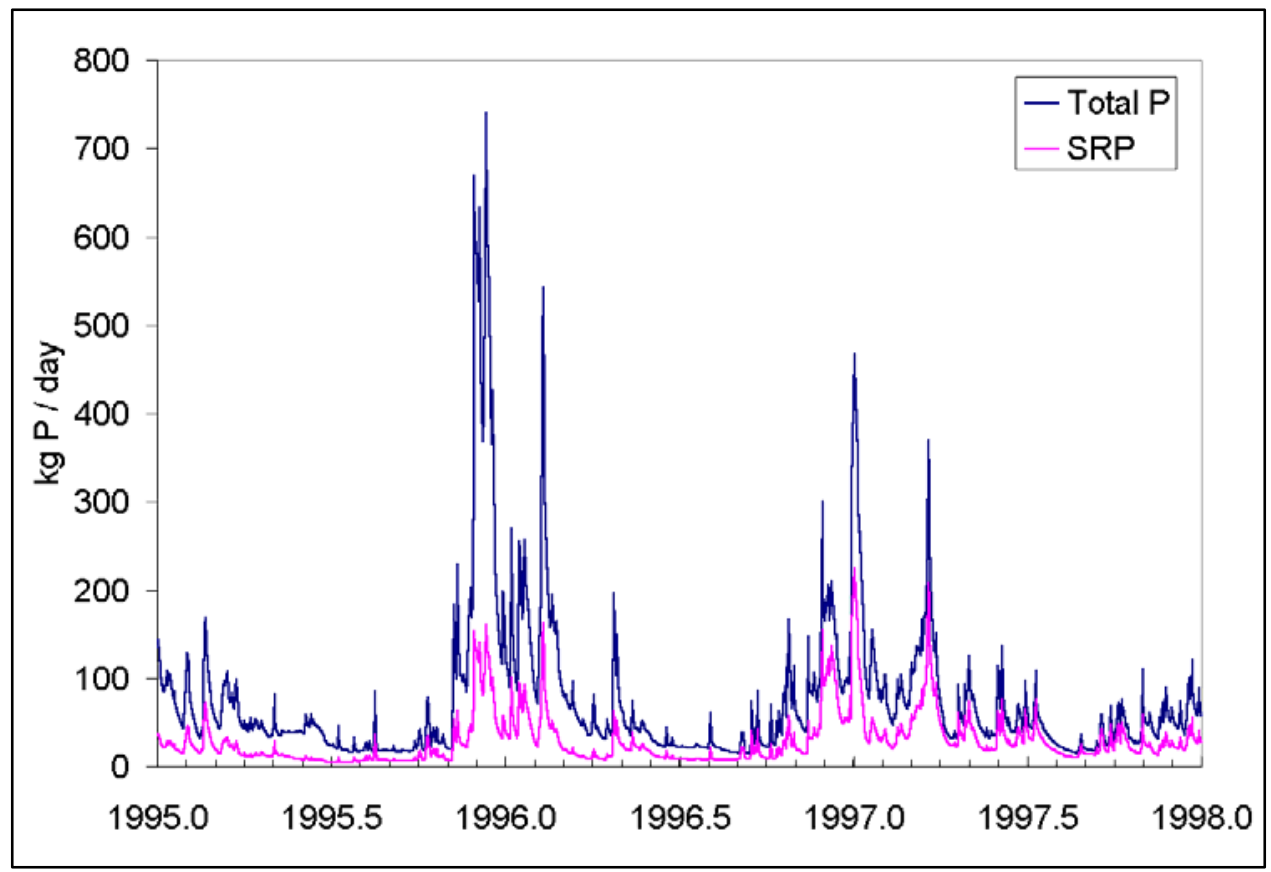

Figure 2-14. Daily phosphorus load from Sammamish River

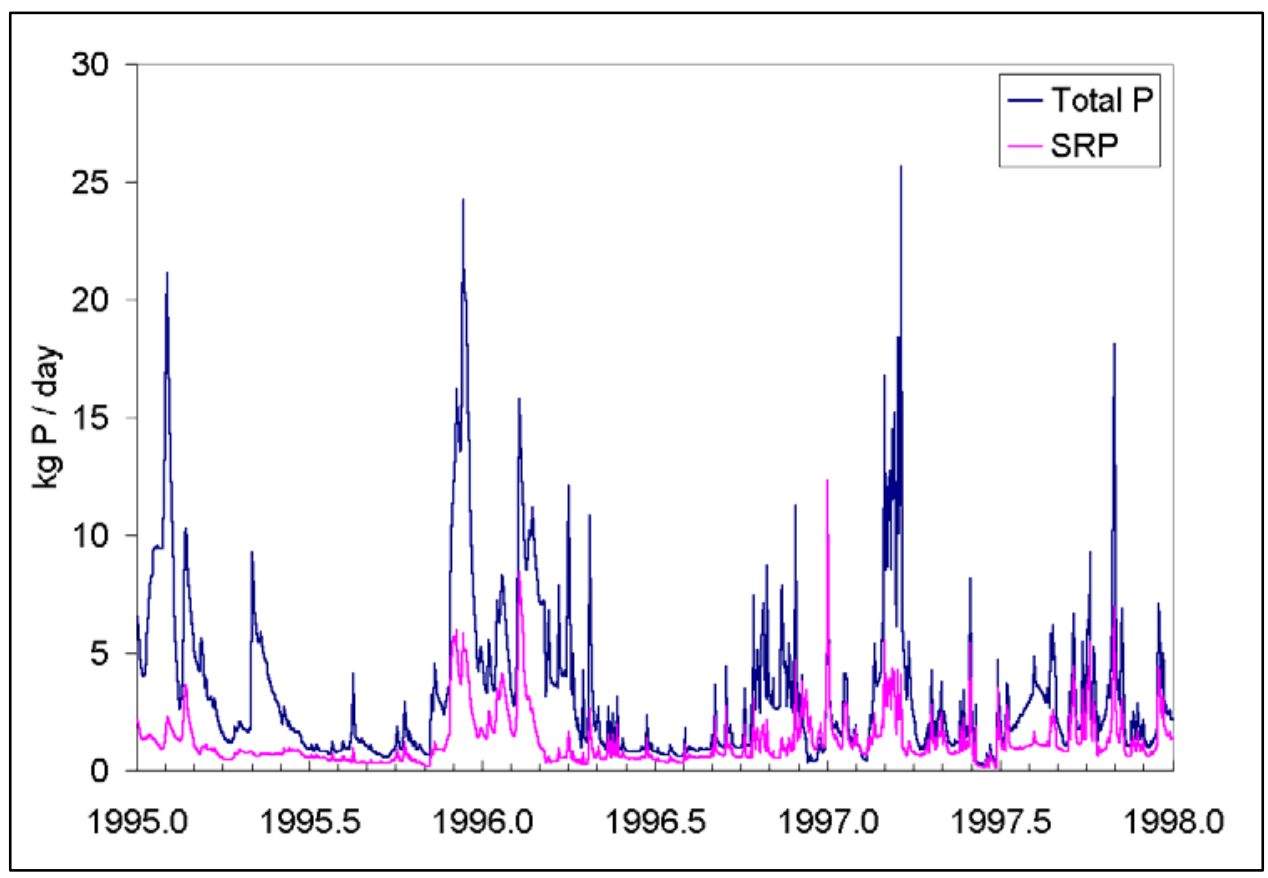

Figure 2-15. Daily phosphorus load from Thornton Creek 


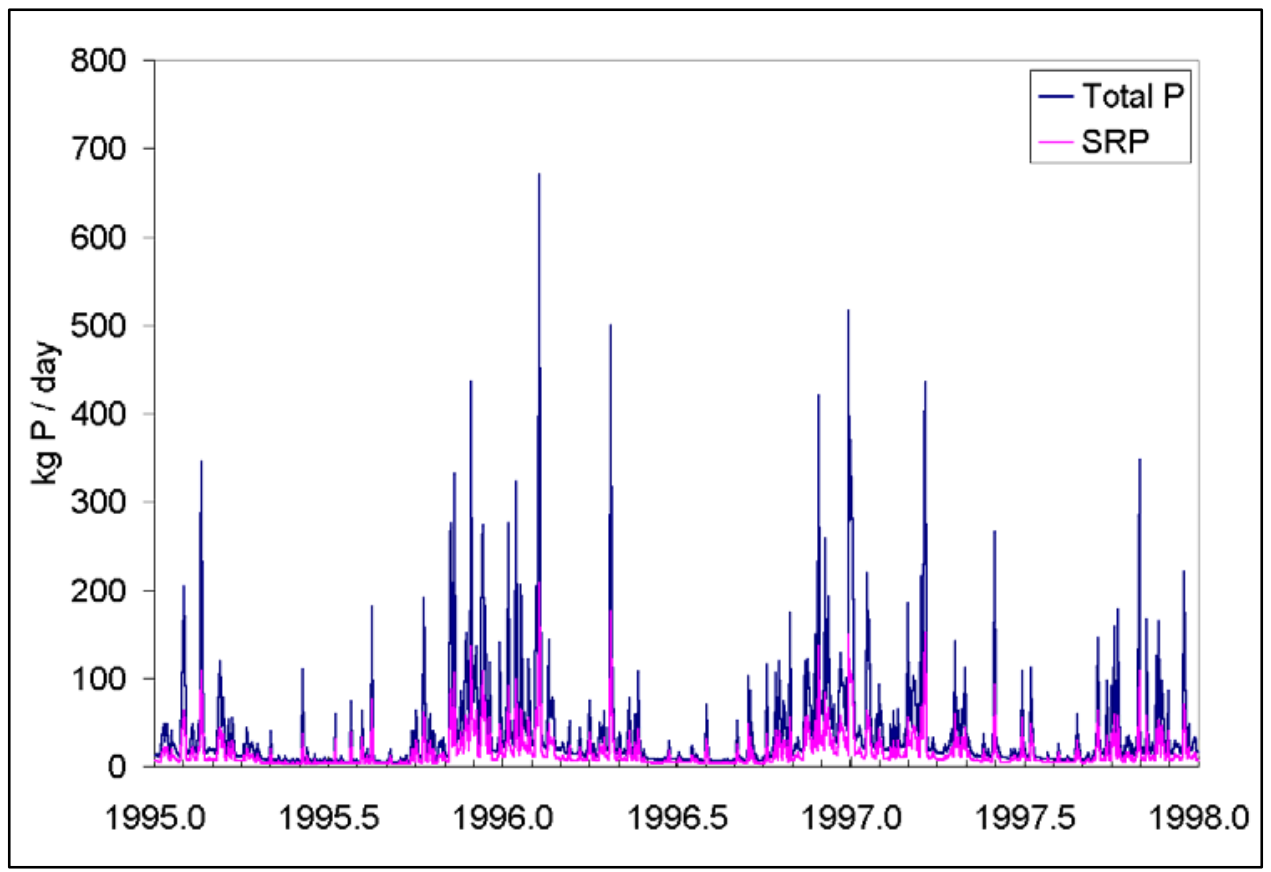

Figure 2-16. Daily phosphorus load from distributed sources

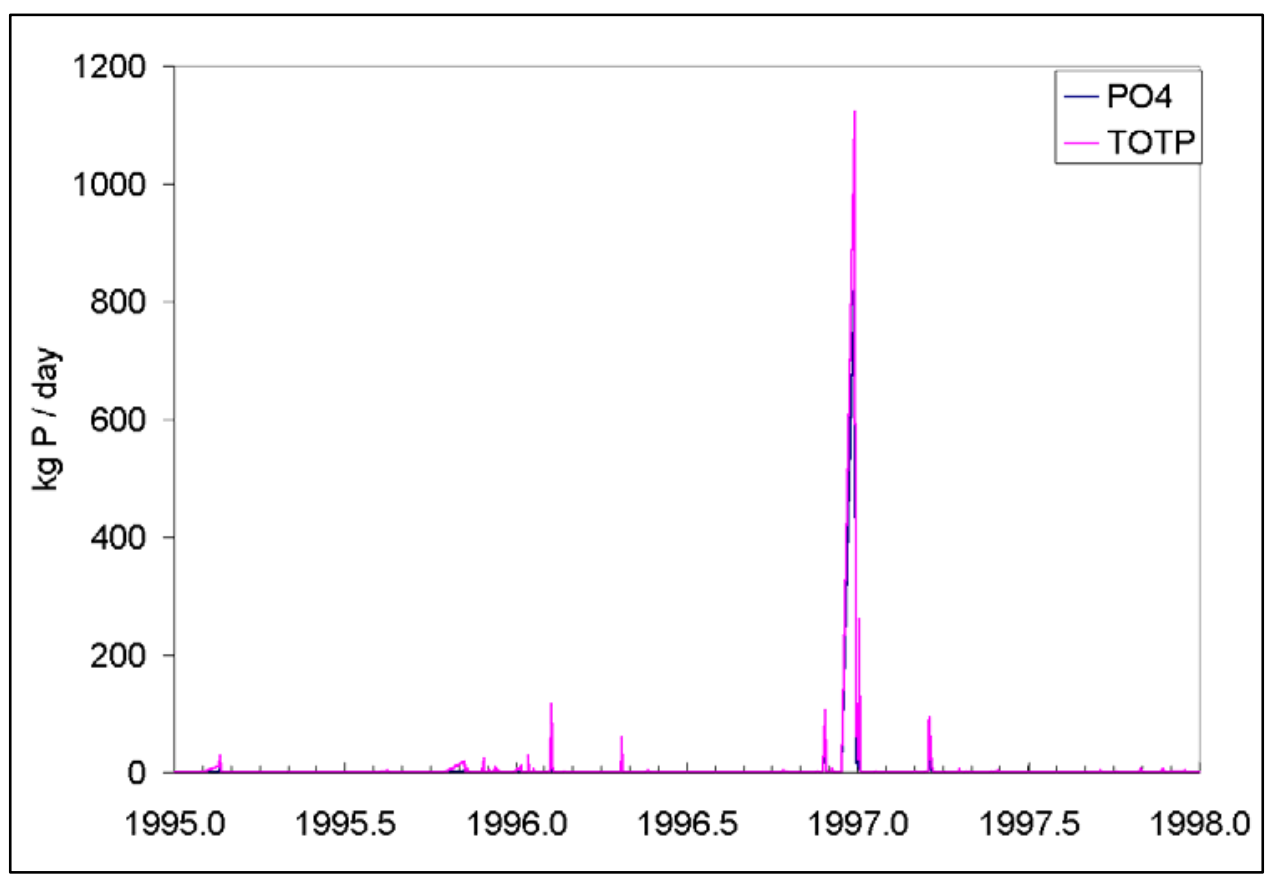

Figure 2-17. Daily phosphorus load from sewer overflows and spills 


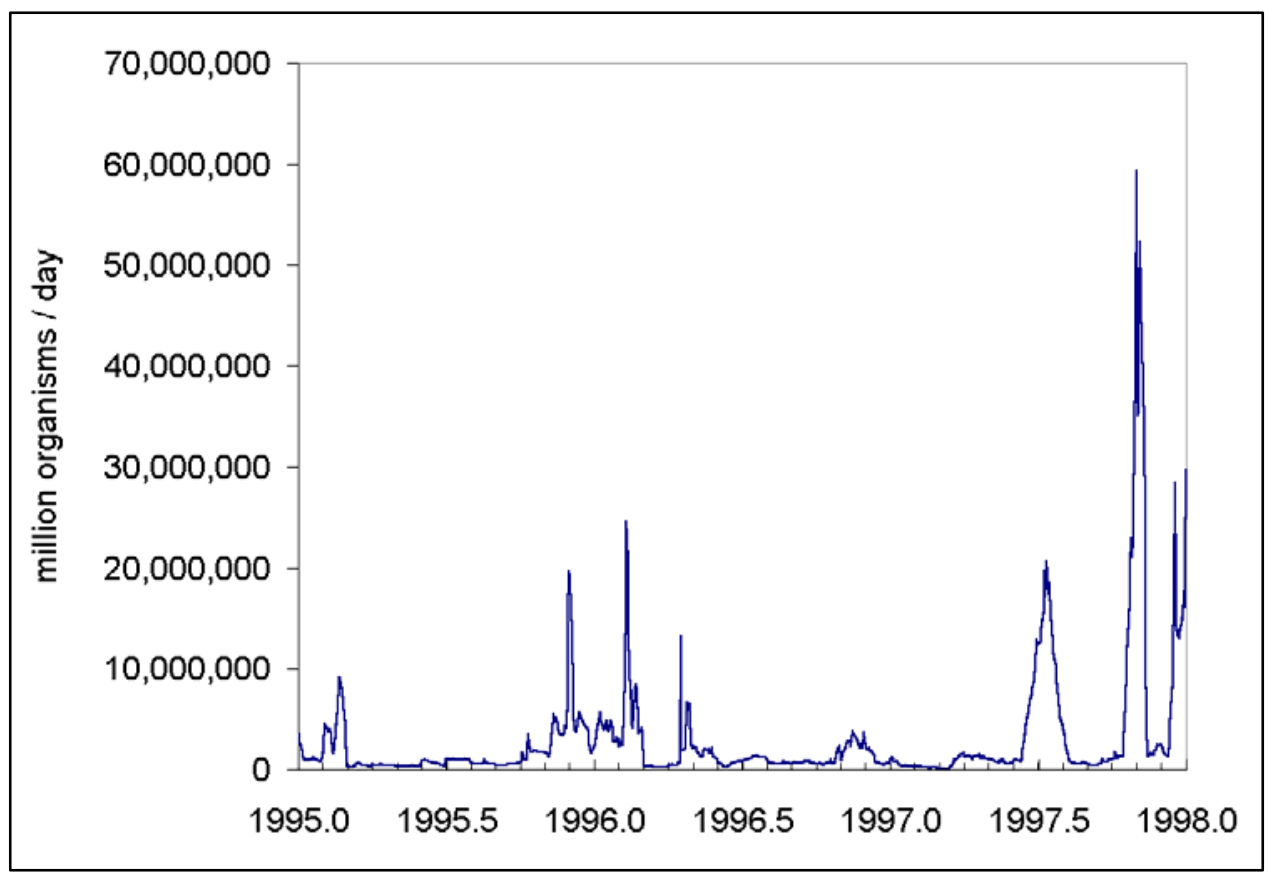

Figure 2-18. Daily fecal coliform load from Cedar River

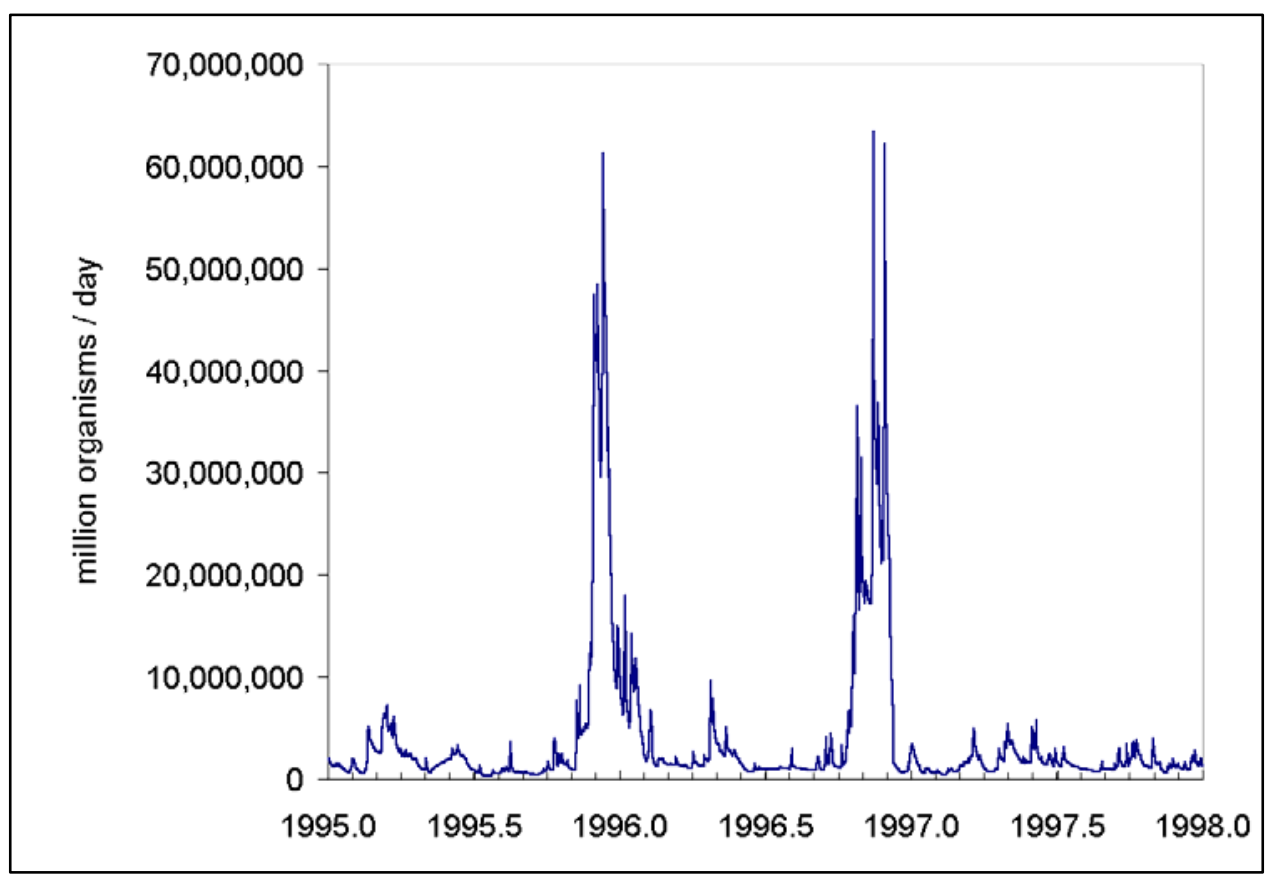

Figure 2-19. Daily fecal coliform load from Sammamish River 


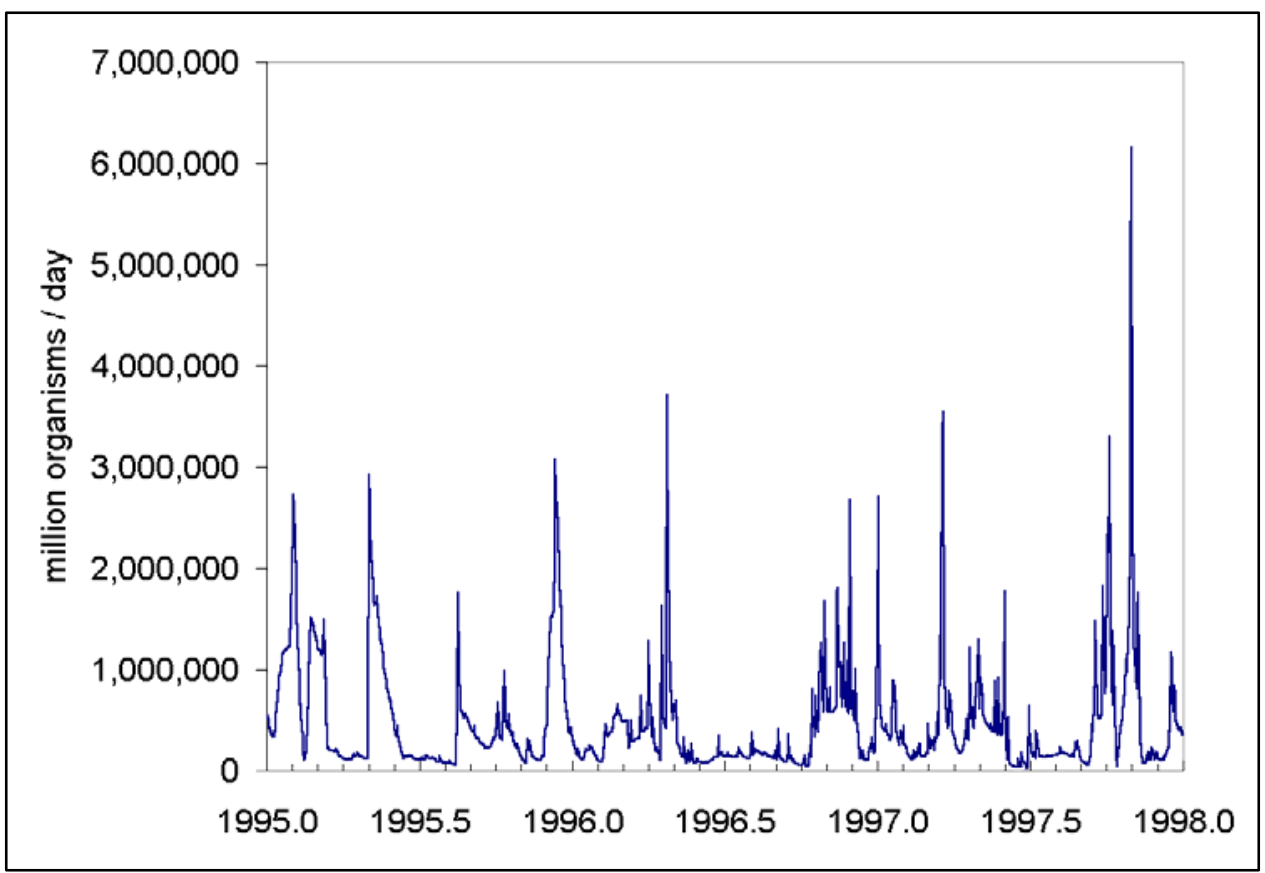

Figure 2-20. Daily fecal coliform load from Thornton Creek

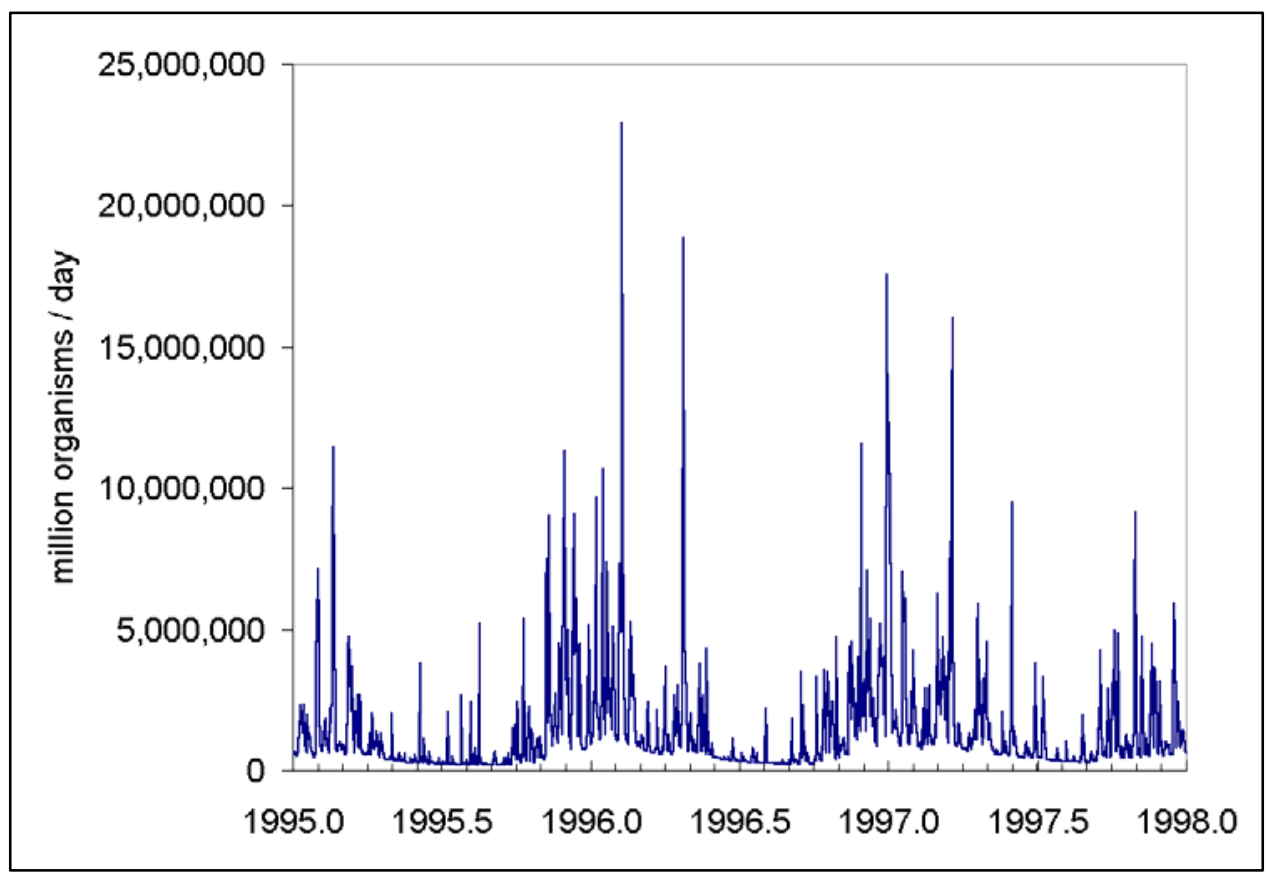

Figure 2-21. Daily fecal coliform load from distributed sources 


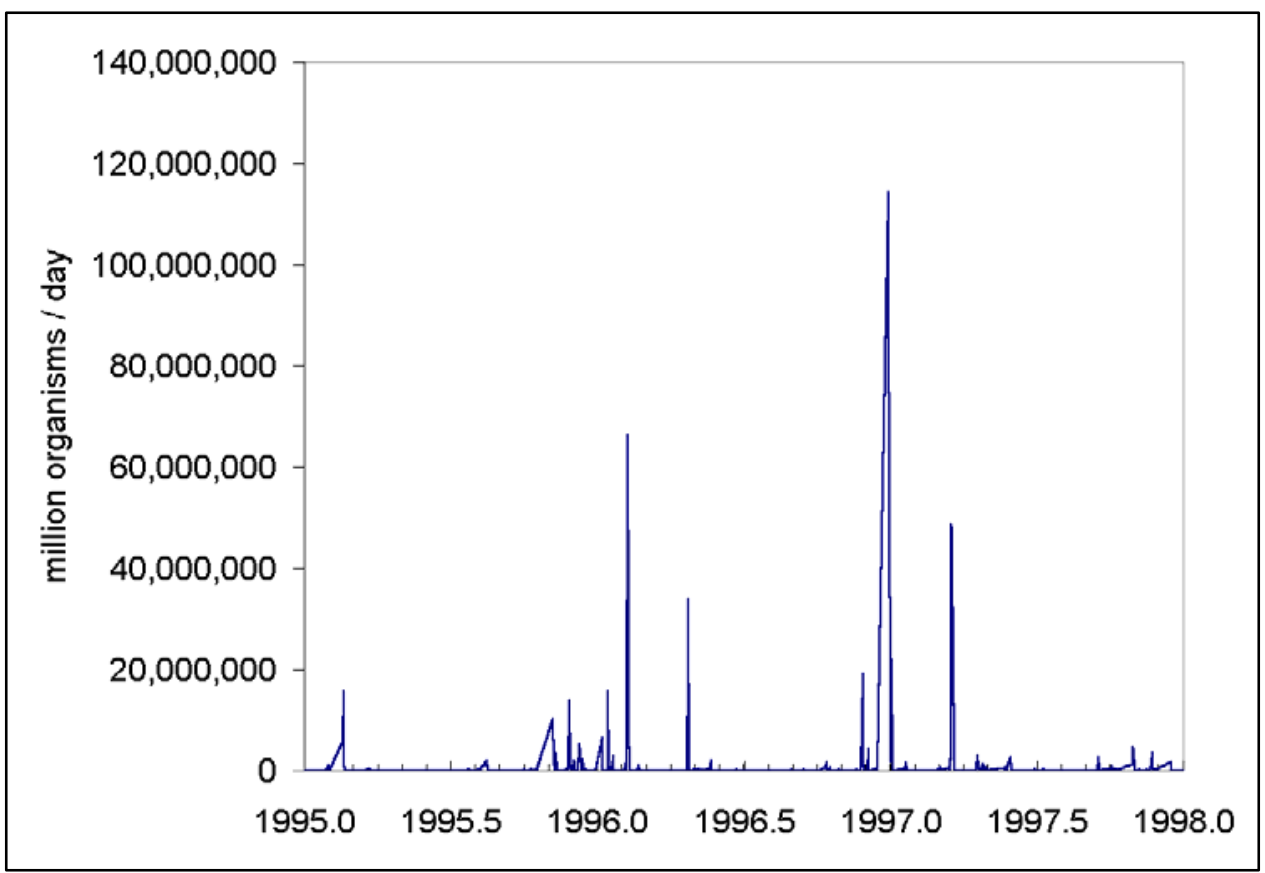

Figure 2-22. Daily fecal coliform load from sewer overflows and spills

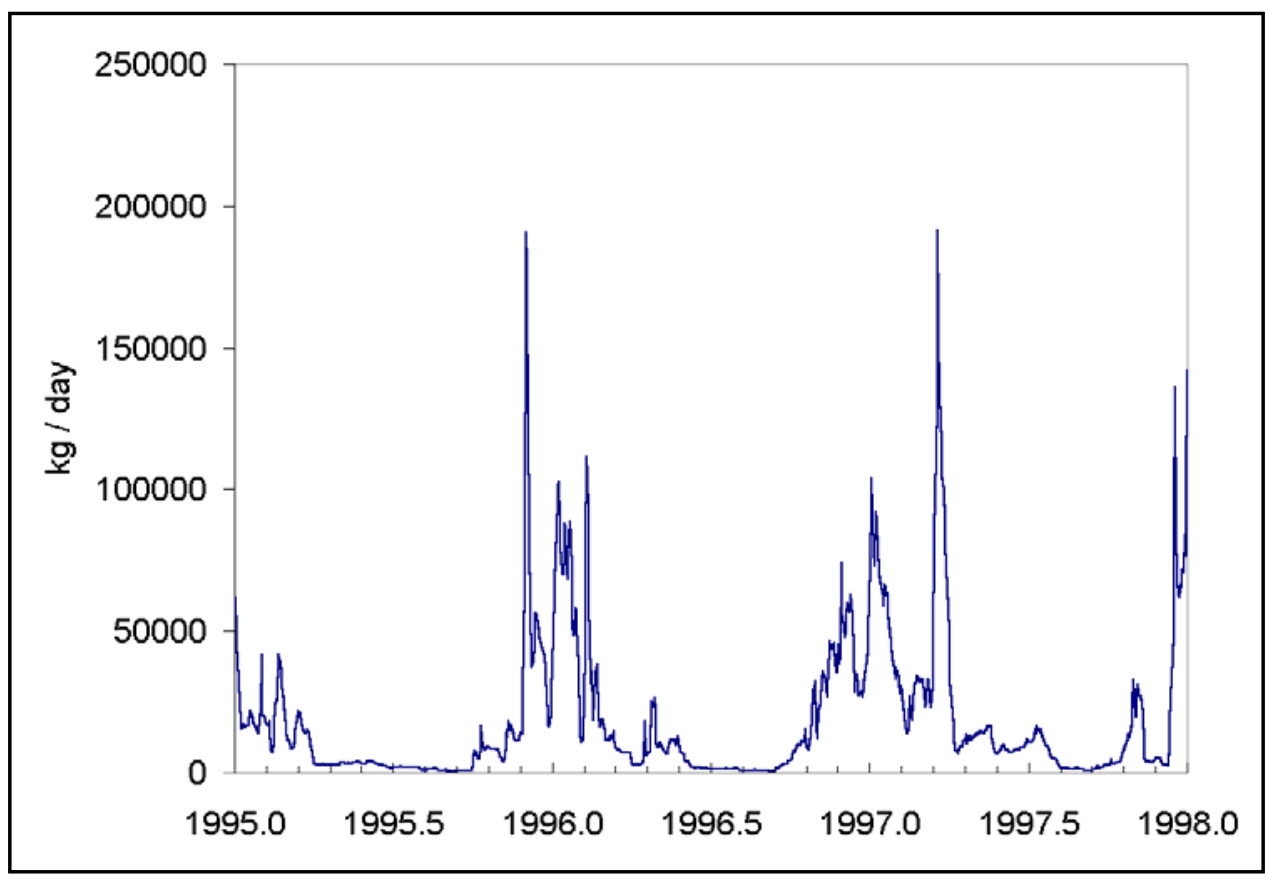

Figure 2-23. Daily suspended solids load from Cedar River 


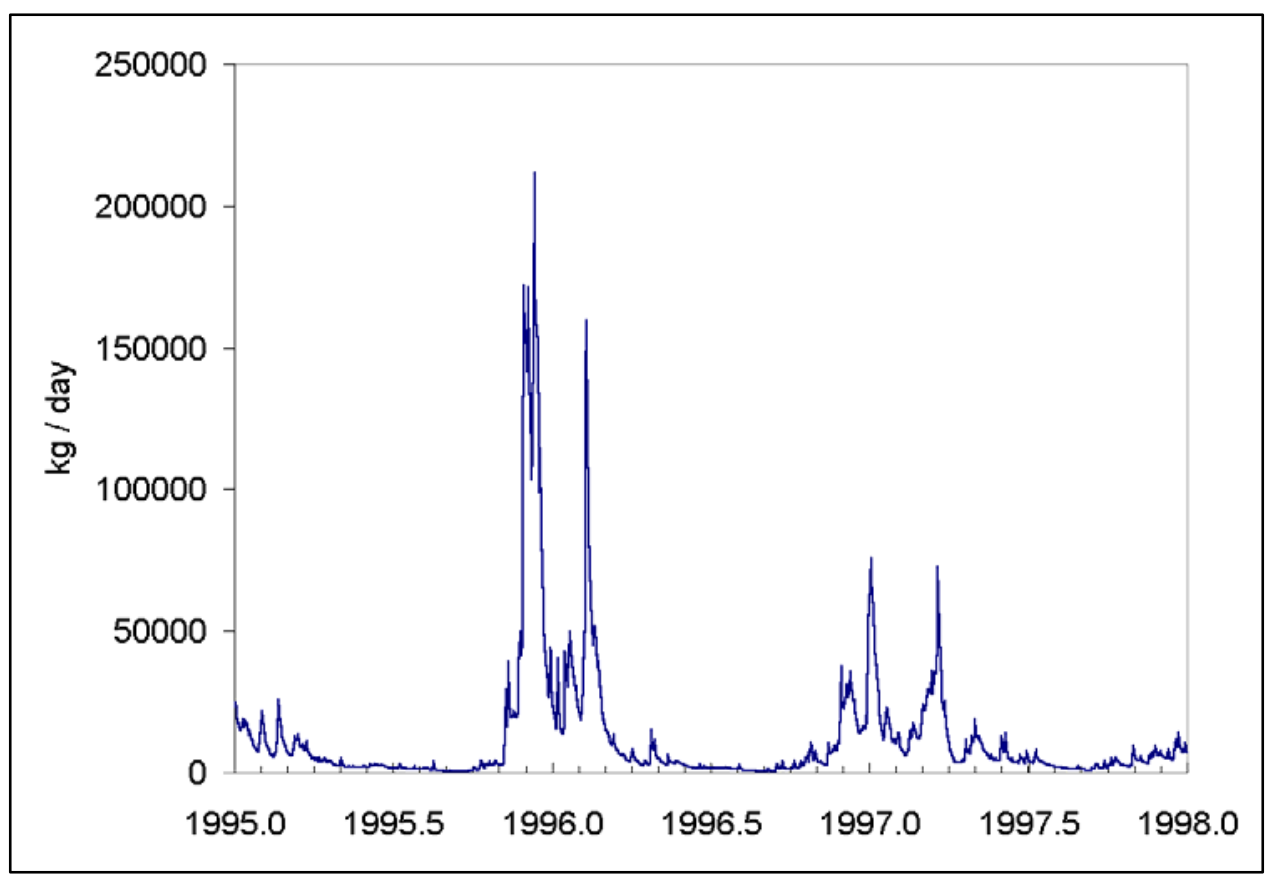

Figure 2-24. Daily suspended solids load from Sammamish River

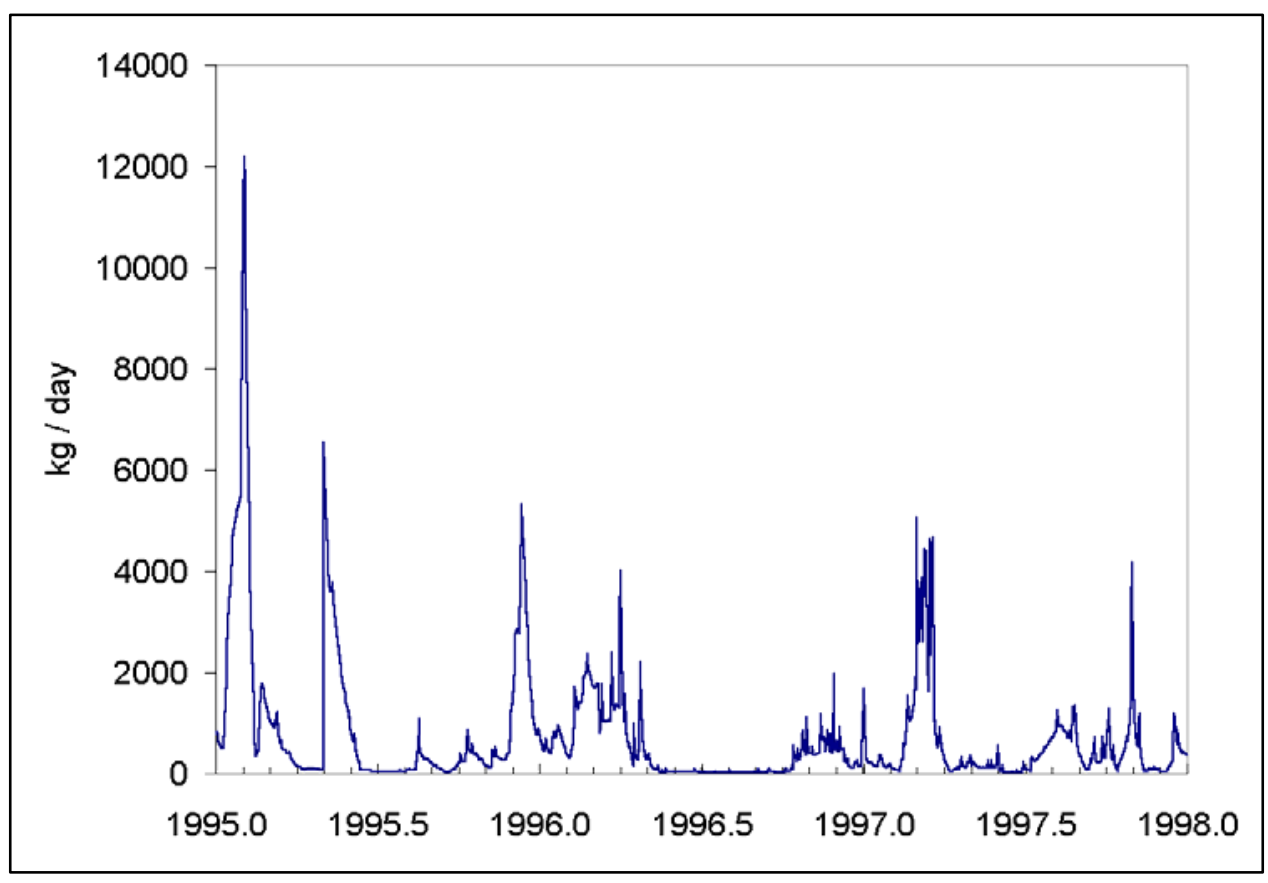

Figure 2-25. Daily suspended solids load from Thornton Creek 


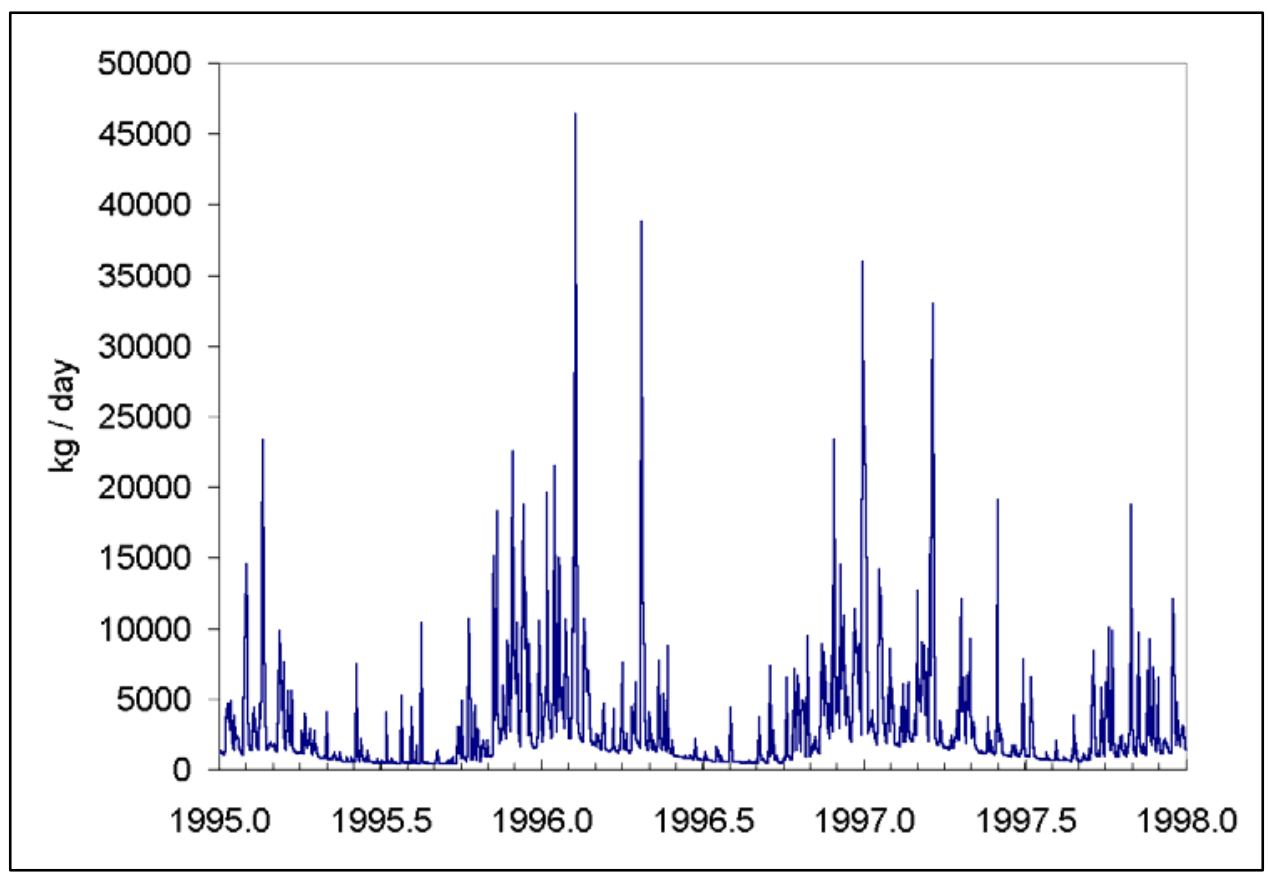

Figure 2-26. Daily suspended solids load from distributed sources

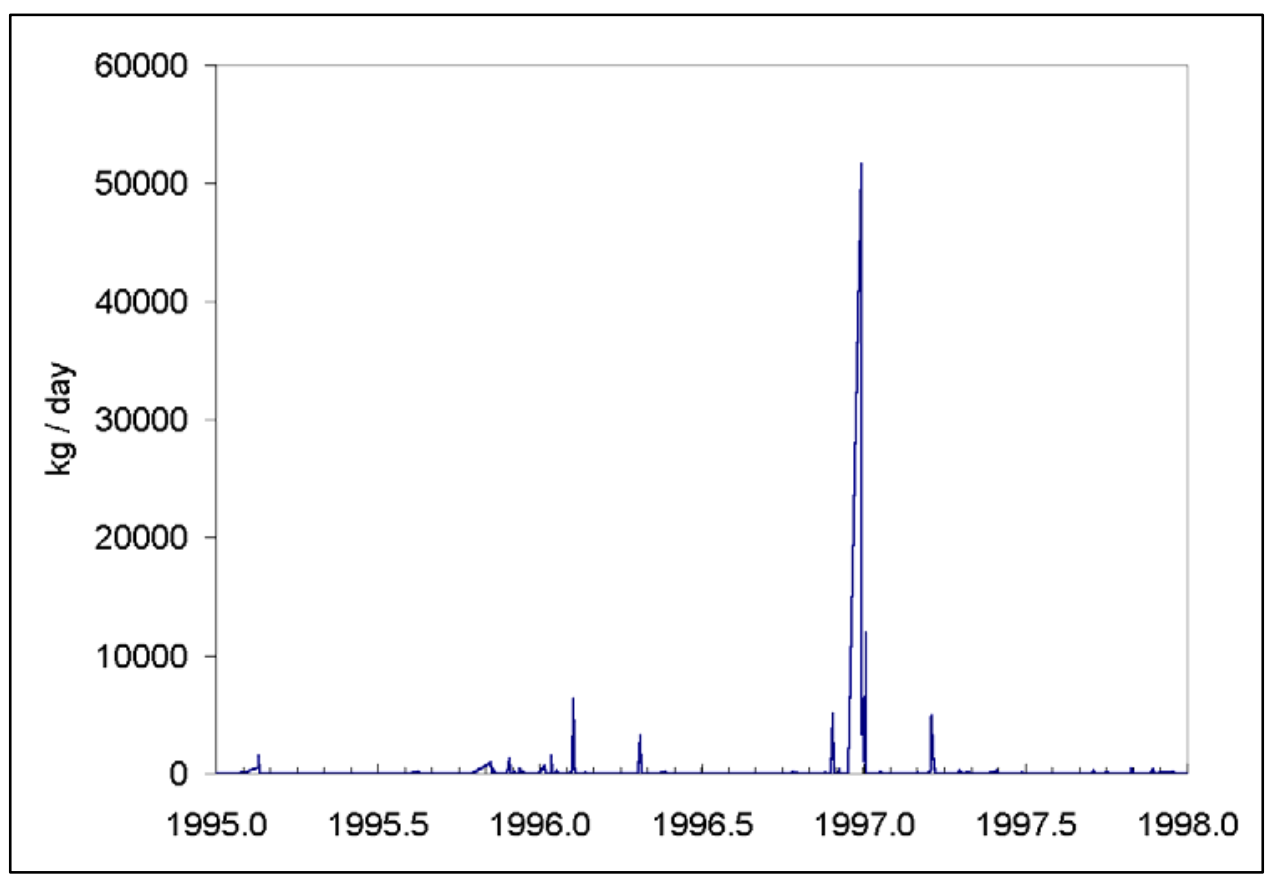

Figure 2-27. Daily suspended solids load from sewer overflows and spills 


\section{Water Quality Model Formulation}

\section{Introduction}

CE-QUAL-ICM was designed to be a flexible, widely applicable eutrophication model. Initial application was to Chesapeake Bay (Cerco and Cole 1994). Subsequent additional applications included the Delaware inland bays (Cerco et al. 1994), Newark Bay (Cerco and Bunch 1997), and the San Juan Bay Estuary (Bunch et al. 2000). Each model application employed a different combination of model features and required addition of system-specific capabilities. This chapter describes general features and site-specific developments of the model as presently applied to the water column of Lake Washington.

\section{Conservation of Mass Equation}

The foundation of CE-QUAL-ICM is the solution to the three-dimensional mass-conservation equation for a control volume. Control volumes correspond to cells on the model grid. CE-QUAL-ICM solves, for each volume and for each state variable, the equation:

$$
\frac{\delta V_{j} \bullet C_{j}}{\delta t}=\sum_{k=1}^{n} Q_{k} \bullet C_{k}+\sum_{k=1}^{n} A_{k} \bullet D_{k} \bullet \frac{\delta C}{\delta x_{k}}+\Sigma S_{j}
$$

in which

$$
\begin{aligned}
V_{j} & =\text { volume of } j^{\text {th }} \text { control volume }\left(\mathrm{m}^{3}\right) \\
C_{j} & =\text { concentration in } j^{\text {th }} \text { control volume }\left(\mathrm{g} \mathrm{m}^{-3}\right) \\
t, x & =\text { temporal and spatial coordinates } \\
n & =\text { number of flow faces attached to } j^{\text {th }} \text { control volume } \\
Q_{k} & =\text { volumetric flow across flow face } k \text { of } j^{\text {th }} \text { control volume }\left(\mathrm{m}^{3} \mathrm{~s}^{-1}\right) \\
C_{k} & =\text { concentration in flow across face } k\left(\mathrm{~g} \mathrm{~m}^{-3}\right) \\
A_{k} & =\text { area of flow face } k\left(\mathrm{~m}^{2}\right)
\end{aligned}
$$


$D_{k}=$ diffusion coefficient at flow face $k\left(\mathrm{~m}^{2} \mathrm{~s}^{-1}\right)$

$S_{j}=$ external loads and kinetic sources and sinks in $j^{\text {th }}$ control volume $\left(\mathrm{g} \mathrm{s}^{-1}\right)$

Solution of Equation 3-1 on a digital computer requires discretization of the continuous derivatives and specification of parameter values. The equation is solved using the QUICKEST algorithm (Leonard 1979) in the horizontal plane and a Crank-Nicolson scheme in the vertical direction. Discrete time-steps, determined by computational stability requirements, are approximately 15 minutes.

\section{State Variables}

As applied to Lake Washington, the CE-QUAL-ICM model incorporates 20 state variables in the water column including physical variables, phytoplankton, multiple forms of carbon, nitrogen, and phosphorus, a pathogen, and two toxicants (Table 3-1). The pathogen and toxicants were added specifically for the Lake Washington application and are described in a subsequent chapter.

\begin{tabular}{||l|l||}
\hline \hline $\begin{array}{l}\text { Table 3-1 } \\
\text { Lake Washington Water Quality }\end{array}$ \\
\hline \hline Temperature & Fixed Solids \\
\hline Phytoplankton & Fecal Coliform \\
\hline Dissolved Organic Carbon & Labile Particulate Organic Carbon \\
\hline Refractory Particulate Organic Carbon & Ammonium \\
\hline Nitrate+Nitrite & Dissolved Organic Nitrogen \\
\hline Labile Particulate Organic Nitrogen & Refractory Particulate Organic Nitrogen \\
\hline Total Phosphate & Dissolved Organic Phosphorus \\
\hline Labile Particulate Organic Phosphorus & Refractory Particulate Organic Phosphorus \\
\hline Chemical Oxygen Demand & Dissolved Oxygen \\
\hline Toxicant One & Toxicant Two \\
\hline \hline
\end{tabular}

\section{Algae}

The coding of CE-QUAL-ICM allows the specification of up to three algal groups. One group is presently activated for Lake Washington.

\section{Zooplankton}

The coding of CE-QUAL-ICM allows the specification of two zooplankton groups: microzooplankton and mesozooplankton. These are not presently activated.

\section{Organic carbon}

Three organic carbon state variables are considered: dissolved, labile particulate, and refractory particulate. Labile and refractory distinctions are based 
upon the time scale of decomposition. Labile organic carbon decomposes on a time scale of days to weeks while refractory organic carbon requires more time. Labile organic carbon decomposes rapidly in the water column or the sediments. Refractory organic carbon decomposes slowly, primarily in the sediments, and may contribute to sediment oxygen demand years after deposition.

\section{Nitrogen}

Nitrogen is first divided into available and unavailable fractions. Available refers to employment in algal nutrition. Two available forms are considered: reduced and oxidized nitrogen. For the Lake Washington application, reduced nitrogen consists exclusively of ammonium. Nitrate and nitrite compose the oxidized nitrogen pool. Both reduced and oxidized nitrogen are utilized to fulfill algal nutrient requirements. The primary reason for distinguishing the two is that ammonium is oxidized by nitrifying bacteria into nitrite and, subsequently, nitrate. This oxidation can be a significant sink of oxygen in the water column and sediments.

Unavailable nitrogen state variables are dissolved organic nitrogen, labile particulate organic nitrogen, and refractory particulate organic nitrogen.

\section{Phosphorus}

As with nitrogen, phosphorus is first divided into available and unavailable fractions. Only a single available form, dissolved phosphate, is considered. The model framework allows for exchange of phosphate between dissolved and particulate (sorbed to solids) forms, but this option is not implemented in the present application. Three forms of unavailable phosphorus are considered: dissolved organic phosphorus, labile particulate organic phosphorus, and refractory particulate organic phosphorus.

\section{Silica}

Silica is included in the complete version of CE-QUAL-ICM but is not activated in the Lake Washington application.

\section{Chemical oxygen demand}

Chemical oxygen demand is the concentration of reduced substances that are oxidized by abiotic processes. In fresh water, a primary component of chemical oxygen demand is methane released from sediments. Oxidation of methane may remove substantial quantities of dissolved oxygen from the water column.

\section{Dissolved oxygen}

Dissolved oxygen is required for the existence of higher life forms. Oxygen availability determines the distribution of organisms and the flows of energy and nutrients in an ecosystem. Dissolved oxygen is a central component of the waterquality model. 


\section{Salinity}

Salinity is included in the coding of CE-QUAL-ICM but is not activated in Lake Washington at present.

\section{Temperature}

Temperature is a primary determinant of the rate of biochemical reactions. Reaction rates increase as a function of temperature although extreme temperatures may result in the mortality of organisms and a decrease in kinetics rates.

\section{Fixed solids}

Fixed solids are the mineral fraction of total suspended solids. Solids are considered primarily for their role in light attenuation.

The remainder of this chapter is devoted to detailing the kinetics sources and sinks and to reporting parameter values. For notational simplicity, the transport terms are dropped in the reporting of kinetics formulations.

\section{Algae}

Algal sources and sinks in the conservation equation include production, metabolism, predation, and settling. These are expressed as

$$
\frac{\delta}{\delta t} B=\left(G-B M-W a \bullet \frac{\delta}{\delta z}\right) B-P R
$$

in which

$$
\begin{aligned}
B & =\text { algal biomass, expressed as carbon }\left(\mathrm{g} \mathrm{C} \mathrm{m}^{-3}\right) \\
G & =\text { growth }\left(\text { day }^{-1}\right) \\
B M & =\text { basal metabolism }\left(\text { day }^{-1}\right) \\
W a & =\text { algal settling velocity }\left(\mathrm{m} \mathrm{day}^{-1}\right) \\
P R & =\text { predation }\left(\mathrm{g} \mathrm{C} \mathrm{m}^{-3} \text { day }^{-1}\right) \\
z & =\text { vertical coordinate }
\end{aligned}
$$

\section{Production}

Production by phytoplankton is determined by the intensity of light, by the availability of nutrients, and by the ambient temperature.

\section{Light}

The influence of light on phytoplankton production is represented by a chlorophyll-specific production equation (Jassby and Platt 1976): 


$$
P^{B}=P^{B} m \frac{I}{\sqrt{I^{2}+I k^{2}}}
$$

in which:

$$
\begin{aligned}
P^{B} & =\text { photosynthetic rate }\left(\mathrm{g} \mathrm{C} \mathrm{g}^{-1} \mathrm{Chl} \mathrm{day}^{-1}\right) \\
P^{B} m & =\text { maximum photosynthetic rate }\left(\mathrm{g} \mathrm{C} \mathrm{g}^{-1} \mathrm{Chl} \mathrm{day}^{-1}\right) \\
I & =\text { irradiance }\left(\mathrm{E} \mathrm{m}^{-2} \text { day }^{-1}\right)
\end{aligned}
$$

Parameter $I k$ is defined as the irradiance at which the initial slope of the production versus irradiance relationship (Figure 3-1) intersects the value of $P^{B} m$ :

$$
I k=\frac{P^{B} m}{\alpha}
$$

in which $\alpha$ is the initial slope of production versus irradiance relationship ( $\mathrm{g} \mathrm{C} \mathrm{g}^{-1}$ $\left.\operatorname{Chl}\left(\mathrm{E} \mathrm{m}^{-2}\right)^{-1}\right)$.

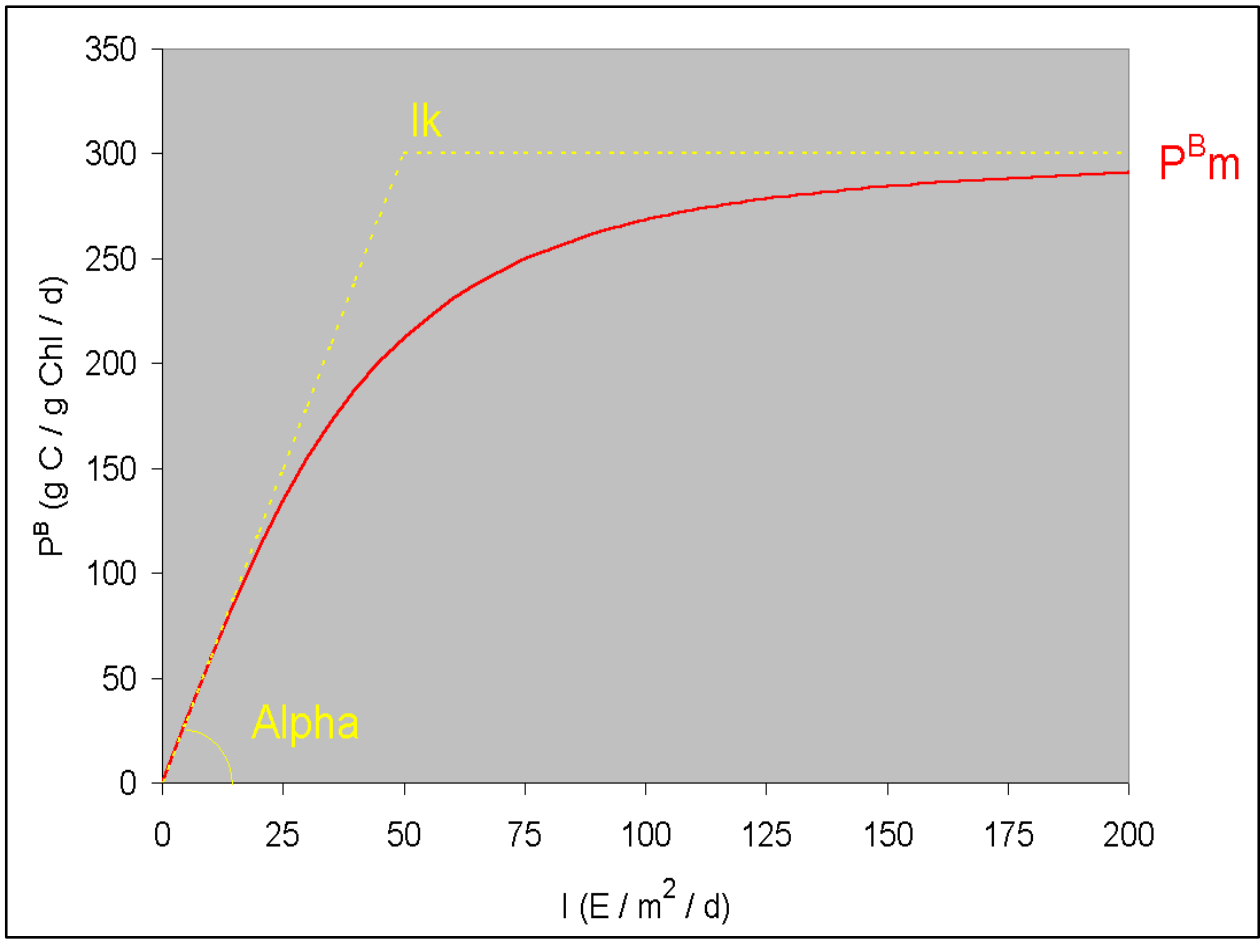

Figure 3-1. Production versus irradiance curve

Chlorophyll-specific production rate is readily converted to carbon-specific growth rate, for use in Equation 3-2, through division by the carbon-tochlorophyll ratio: 


$$
G=\frac{P^{B}}{C C h l}
$$

in which $C C h l$ is the carbon-to-chlorophyll ratio ( $\mathrm{g} \mathrm{C} \mathrm{g}^{-1}$ chlorophyll a).

\section{Nutrients}

Carbon, nitrogen, and phosphorus are the primary nutrients required for algal growth. Inorganic carbon is usually available in excess and is not considered in the model. The effects of the remaining nutrients on growth are described by the formulation commonly referred to as Michaelis-Menton kinetics (Figure 3-2):

$$
f(N)=\frac{D}{K H d+D}
$$

in which

$$
\begin{aligned}
f(N) & =\text { nutrient limitation on algal production }(0 \leq f(N) \leq 1) \\
D & =\text { concentration of dissolved nutrient }\left(\mathrm{g} \mathrm{m}^{-3}\right) \\
K H d & =\text { half-saturation constant for nutrient uptake }\left(\mathrm{g} \mathrm{m}^{-3}\right)
\end{aligned}
$$

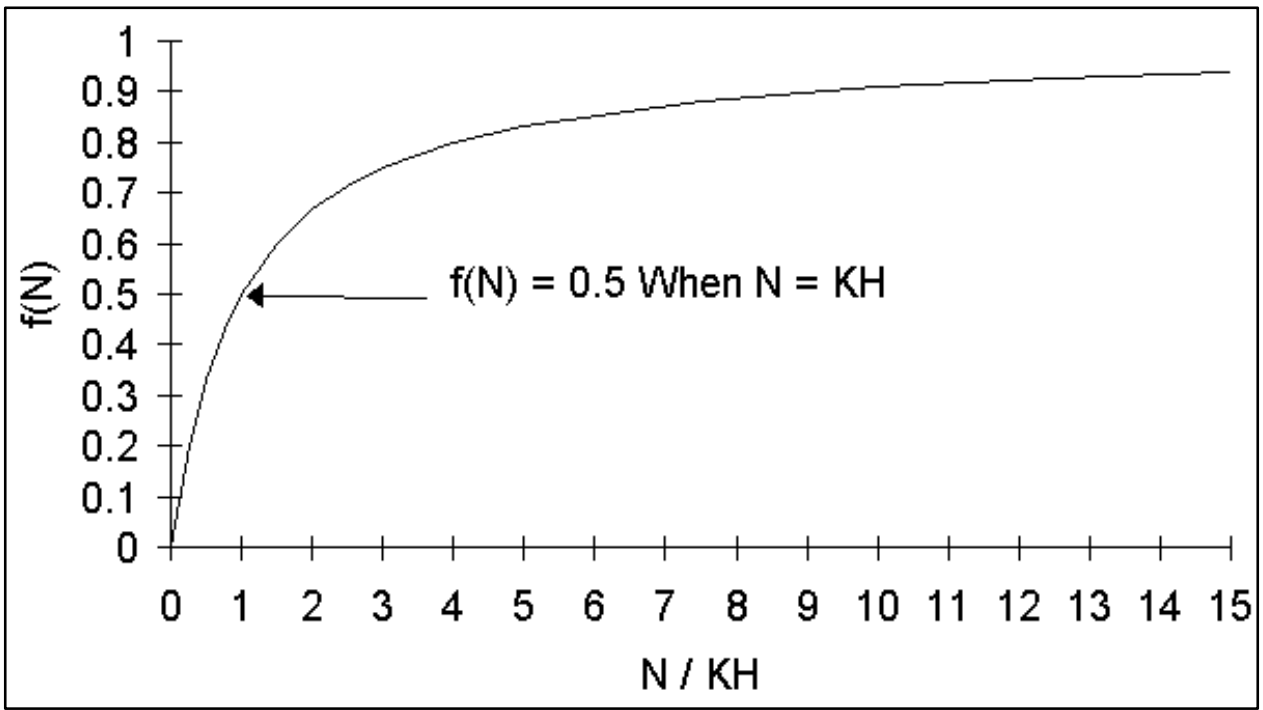

Figure 3-2. Michaelis-Menton formulation for nutrient-limited growth

\section{Temperature}

Algal production increases as a function of temperature until an optimum temperature or temperature range is reached. Above the optimum, production declines until a temperature lethal to the organisms is attained. Numerous functional representations of temperature effects are available. Inspection of growth versus temperature data indicates a function similar to a Gaussian probability curve (Figure 3-3) provides a good fit to observations: 


$$
\begin{gathered}
f(T)=e^{-K T g 1 \cdot(T-T o p t)^{2}} \text { when } T \leq \text { Topt } \\
=e^{-K T g 2 \cdot(T o p t-T)^{2}} \text { when } T>\text { Topt }
\end{gathered}
$$

in which

$T=$ temperature $\left({ }^{\circ} \mathrm{C}\right)$

Topt $=$ optimal temperature for algal growth $\left({ }^{\circ} \mathrm{C}\right)$

$K T g 1=$ effect of temperature below Topt on growth $\left({ }^{\circ} \mathrm{C}^{-2}\right)$

$K T g 2=$ effect of temperature above Topt on growth $\left({ }^{\circ} \mathrm{C}^{-2}\right)$

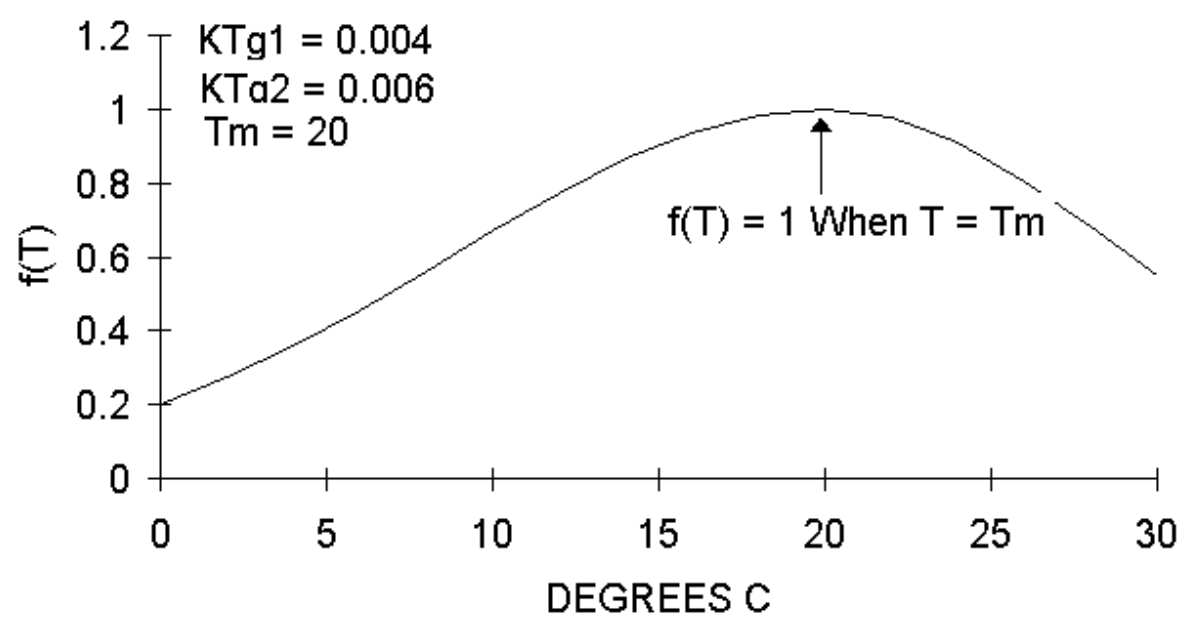

Figure 3-3. Relation of algal production to temperature

\section{Constructing the photosynthesis versus irradiance curve}

A production versus irradiance relationship is constructed for each model cell at each time-step. First, the maximum photosynthetic rate under ambient temperature and nutrient concentrations is determined:

$$
P^{B} m(N, T)=P^{B} m \bullet f(T) \bullet \frac{D}{K H d+D}
$$

in which $P^{B} m(N, T)$ is the maximum photosynthetic rate under ambient temperature and nutrient concentrations $\left(\mathrm{g} \mathrm{C} \mathrm{g}^{-1} \mathrm{Chl} \mathrm{day}^{-1}\right)$. The single most limiting nutrient is employed in determining the nutrient limitation.

Next, parameter $I k$ is derived from Equation 3-4. Finally, the production versus irradiance relationship is constructed using $P^{B} m(N, T)$ and $I k$. The resulting production versus irradiance curve exhibits three regions (Figure 3-4). For $I \gg>$ $I k$, the value of the term $I /\left(I^{2}+I k^{2}\right)^{1 / 2}$ approaches unity and temperature and nutrients are the primary factors that influence production. For $I<<I k$, production is determined solely by $\alpha$ and irradiance $I$. In the region where the 
initial slope of the production versus irradiance curve intercepts the line indicating production at optimal illumination, $I \approx I k$, production is determined by the combined effects of temperature, nutrients, and light.

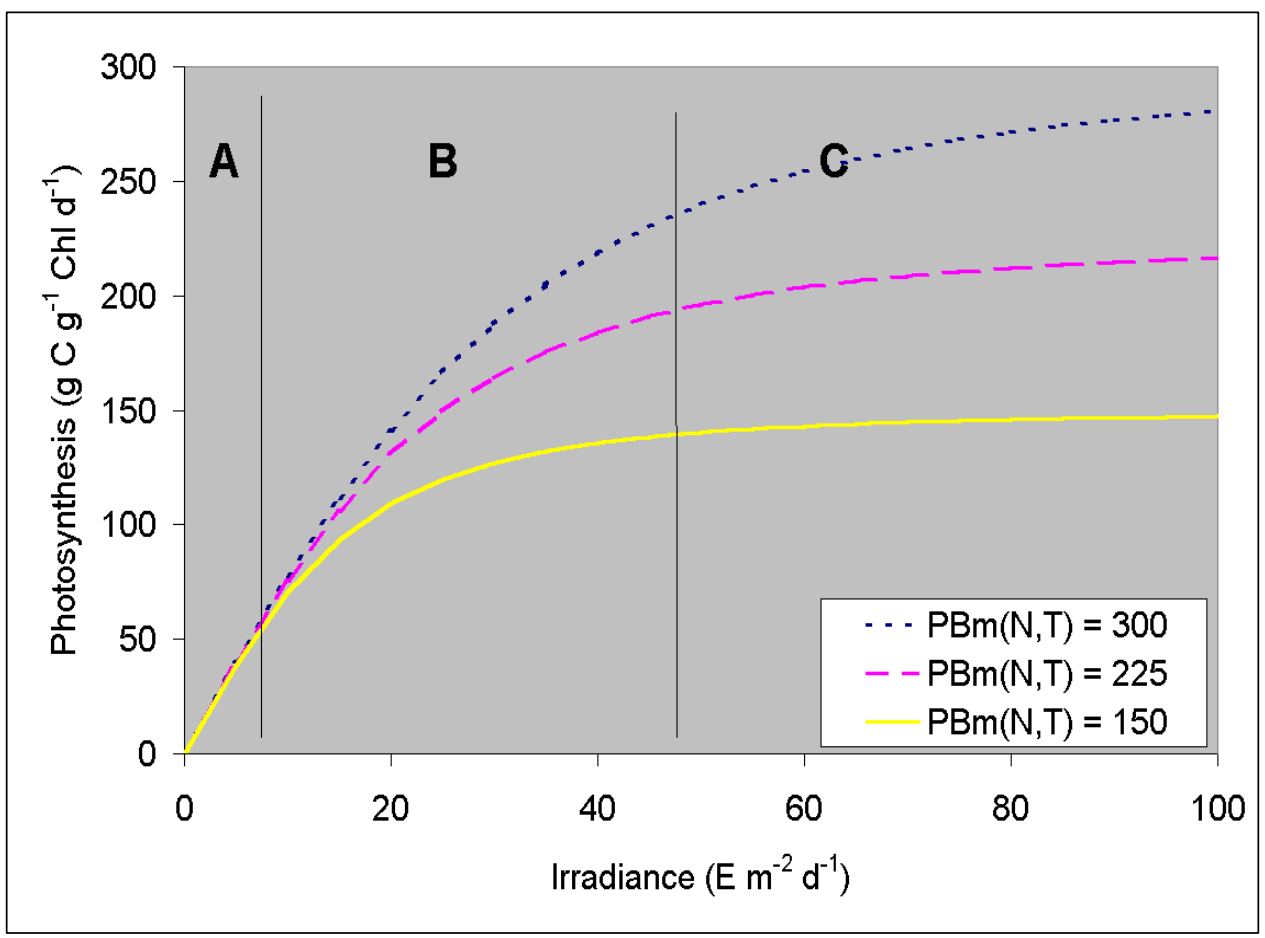

Figure 3-4. Effects of light and nutrients on production versus irradiance curve, calculated for $\alpha=8\left(\mathrm{~g} \mathrm{C} \mathrm{g}^{-1} \mathrm{Chl}\left(\mathrm{E} \mathrm{m}^{-2}\right)^{-1}\right)$

\section{Irradiance}

Solar radiation at the water surface is input to the model as part of the heat transfer calculations. An empirical conversion is employed to convert between short-wave solar radiation and photosynthetically active radiation (Einstein's $\mathrm{m}^{-2}$ $=0.143 \bullet$ watts $\mathrm{m}^{-2}$ ).

\section{Respiration}

Two forms of respiration are considered in the model: photorespiration and basal metabolism. Photorespiration represents the energy expended by carbon fixation and is a fixed fraction of production. In the event of no production (e.g., at night), photorespiration is zero. Basal metabolism is a continuous energy expenditure to maintain basic life processes. In the model, metabolism is considered to be an exponentially increasing function of temperature (Figure 3-5). Total respiration is represented:

$$
R=\operatorname{Presp} \bullet G+B M \bullet e^{K T b \bullet(T-T r e f)}
$$

in which 


$$
\begin{aligned}
\text { Presp } & =\text { photorespiration }(0 \leq \operatorname{Pres} p \leq 1) \\
B M & =\text { metabolic rate at reference temperature Tref }\left(\text { day }^{-1}\right) \\
K T b & =\text { effect of temperature on metabolism }\left({ }^{\circ} \mathrm{C}^{-1}\right) \\
\text { Tref } & =\text { reference temperature for metabolism }\left({ }^{\circ} \mathrm{C}\right)
\end{aligned}
$$

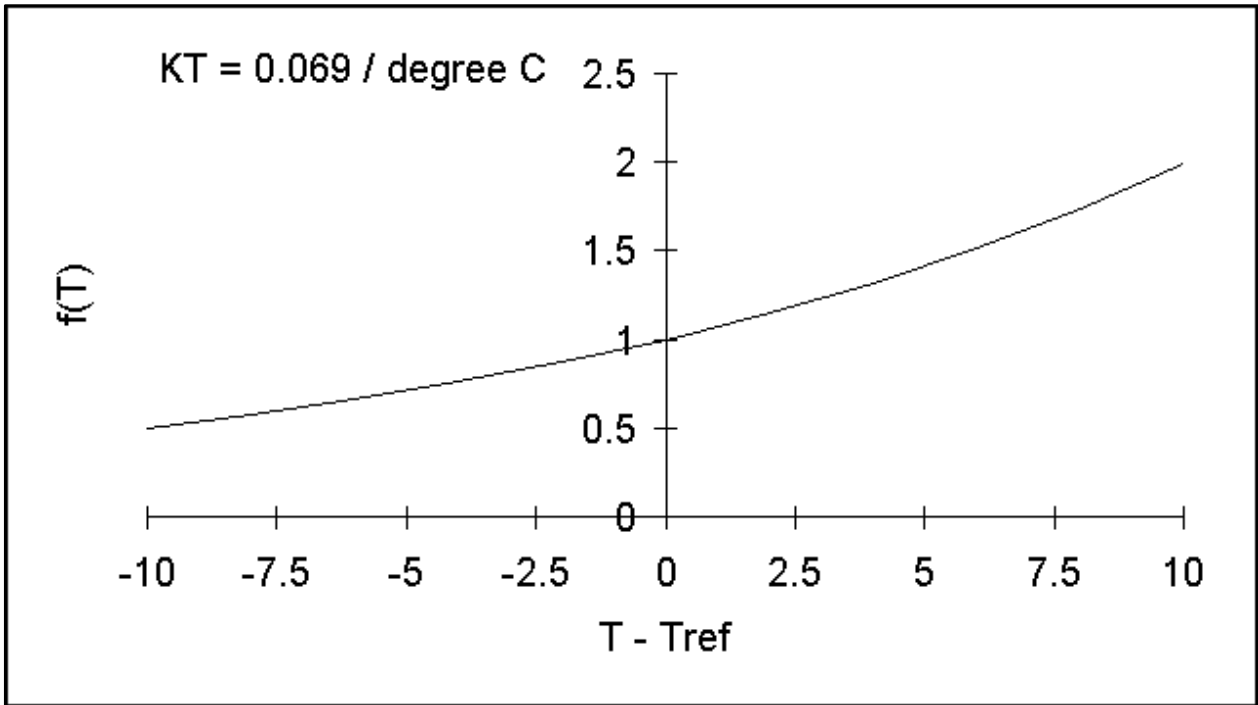

Figure 3-5. Exponential temperature relationship employed for metabolism and other processes

\section{Predation}

The predation term includes the activity of zooplankton, filter-feeding benthos, and other pelagic filter feeders including planktivorous fish. A variety of formulations are available to represent predation. For Lake Washington, a piecewise linear predation term worked well:

$$
\mathrm{PR}=B P R \bullet B
$$

in which $B P R$ is the base predation rate $\left(\right.$ day $\left.^{-1}\right)$.

\section{Accounting for algal phosphorus}

The amount of phosphorus incorporated in algal biomass is quantified through a stoichiometric ratio. Thus, total phosphorus in the model is expressed:

$$
T o t P=\mathrm{PO}_{4}+A P C \bullet B+D O P+L P O P+R P O P
$$

in which

$$
\begin{aligned}
\text { Tot } P & =\text { total phosphorus }\left(\mathrm{g} \mathrm{P} \mathrm{m}^{-3}\right) \\
\mathrm{PO}_{4} & =\text { dissolved phosphate }\left(\mathrm{g} \mathrm{P} \mathrm{m}^{-3}\right)
\end{aligned}
$$




$$
\begin{aligned}
A P C & =\text { algal phosphorus-to-carbon ratio }\left(\mathrm{g} \mathrm{P} \mathrm{g}^{-1} \mathrm{C}\right) \\
D O P & =\text { dissolved organic phosphorus }\left(\mathrm{g} \mathrm{P} \mathrm{m}^{-3}\right) \\
L P O P & =\text { labile particulate organic phosphorus }\left(\mathrm{g} \mathrm{P} \mathrm{m}^{-3}\right) \\
R P O P & =\text { refractory particulate organic phosphorus }\left(\mathrm{g} \mathrm{P} \mathrm{m}^{-3}\right)
\end{aligned}
$$

Algae take up dissolved phosphate during production and release dissolved phosphate and organic phosphorus through respiration. The fate of phosphorus released by respiration is determined by empirical distribution coefficients. The fate of algal phosphorus recycled by predation is determined by a second set of distribution parameters.

\section{Accounting for algal nitrogen}

Model nitrogen state variables include ammonium, nitrate+nitrite, dissolved organic nitrogen, labile particulate organic nitrogen, and refractory particulate organic nitrogen. The amount of nitrogen incorporated in algal biomass is quantified through a stoichiometric ratio. Thus, total nitrogen in the model is expressed:

$$
T o t N=\mathrm{NH}_{4}+\mathrm{NO}_{23}+A N C \bullet B+D O N+L P O N+R P O N
$$

in which:

$$
\begin{aligned}
\text { Tot } N & =\text { total nitrogen }\left(\mathrm{g} \mathrm{N} \mathrm{m}^{-3}\right) \\
\mathrm{NH}_{4} & =\text { ammonium }\left(\mathrm{g} \mathrm{N} \mathrm{m}^{-3}\right) \\
\mathrm{NO}_{23} & =\text { nitrate+nitrite }\left(\mathrm{g} \mathrm{N} \mathrm{m}^{-3}\right) \\
A N C & =\text { algal nitrogen-to-carbon ratio }\left(\mathrm{g} \mathrm{N} \mathrm{g}^{-1} \mathrm{C}\right) \\
D O N & =\text { dissolved organic nitrogen }\left(\mathrm{g} \mathrm{N} \mathrm{m}^{-3}\right) \\
L P O N & =\text { labile particulate organic nitrogen }\left(\mathrm{g} \mathrm{N} \mathrm{m}^{-3}\right) \\
R P O N & =\text { refractory particulate organic nitrogen }\left(\mathrm{g} \mathrm{N} \mathrm{m}^{-3}\right)
\end{aligned}
$$

As with phosphorus, the fate of algal nitrogen released by metabolism and predation is represented by distribution coefficients.

\section{Algal nitrogen preference}

Algae take up ammonium and nitrate+nitrite during production and release ammonium and organic nitrogen through respiration. Nitrate+nitrite is internally reduced to ammonium before synthesis into biomass occurs (Parsons et al. 1984). Trace concentrations of ammonium inhibit nitrate reduction so that, in the presence of multiple nitrogenous nutrients, ammonium is utilized first. The "preference" of algae for ammonium is expressed by an empirical function (Thomann and Fitzpatrick 1982): 


$$
\begin{gathered}
P N=\mathrm{NH}_{4} \bullet \frac{\mathrm{NO}_{23}}{\left(K H n+\mathrm{NH}_{4}\right) \bullet\left(K H n+\mathrm{NO}_{23}\right)} \\
+\mathrm{NH}_{4} \bullet \frac{K H n}{\left(\mathrm{NH}_{4}+\mathrm{NO}_{23}\right) \bullet\left(K H n+\mathrm{NO}_{23}\right)}
\end{gathered}
$$

in which

$$
\begin{aligned}
P N & =\text { algal preference for ammonium uptake }(0 \leq P n \leq 1) \\
K H n & =\text { half-saturation concentration for algal nitrogen uptake }\left(\mathrm{g} \mathrm{N} \mathrm{m}^{-3}\right)
\end{aligned}
$$

The function has two limiting values (Figure 3-6). When nitrate+nitrite is absent, the preference for ammonium is unity. When ammonium is absent, the preference is zero. In the presence of ammonium and nitrate+nitrite, the preference depends on the abundance of both forms relative to the half-saturation constant for nitrogen uptake. When both ammonium and nitrate+nitrite are abundant, the preference for ammonium approaches unity. When ammonium is scarce but nitrate+nitrite is abundant, the preference decreases in magnitude and a significant fraction of algal nitrogen requirement comes from nitrate+nitrite.

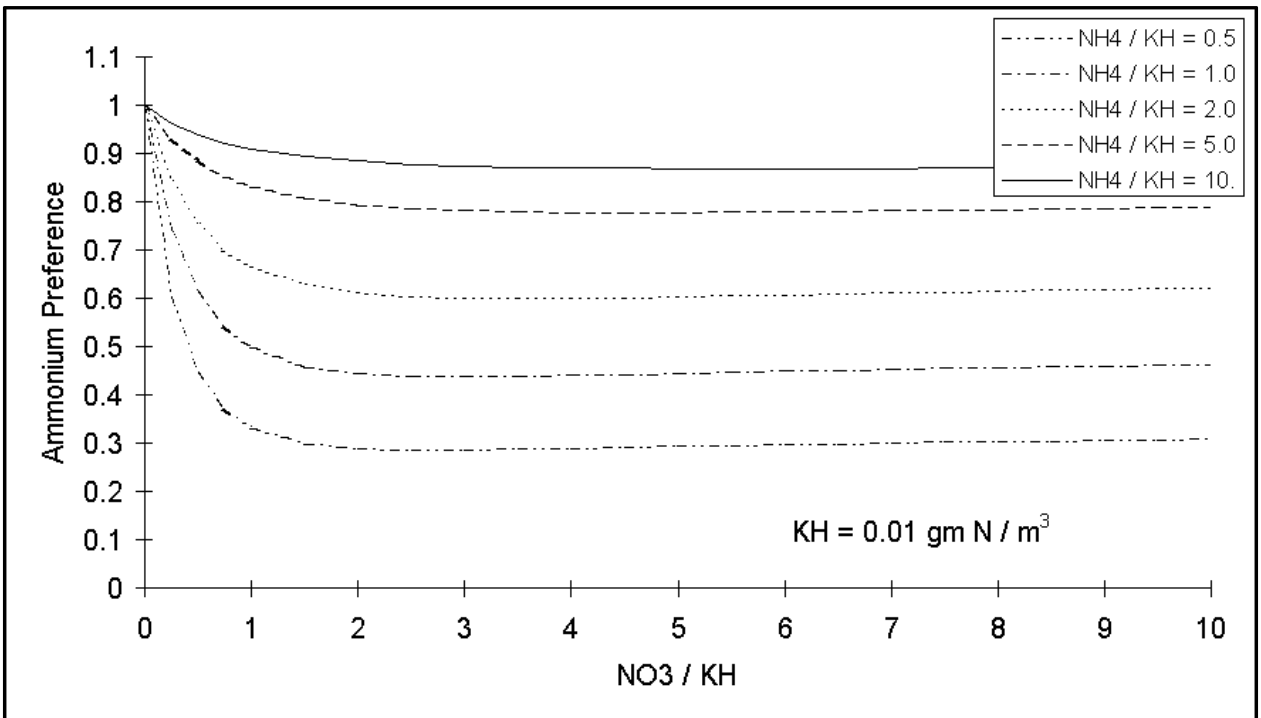

Figure 3-6. Algal ammonium preference

\section{Effect of algae on dissolved oxygen}

Algae produce oxygen during photosynthesis and consume oxygen through respiration. The quantity produced depends on the form of nitrogen utilized for growth. More oxygen is produced per unit of carbon fixed when nitrate is the algal nitrogen source than when ammonium is the source. The following equations describe algal uptake of carbon and nitrogen and production of dissolved oxygen (Morel 1983). 


$$
\begin{gathered}
106 \mathrm{CO}_{2}+16 \mathrm{NH}_{4}^{+}+\mathrm{H}_{2} \mathrm{PO}_{4}^{-}+106 \mathrm{H}_{2} \mathrm{O} \rightarrow \\
\text { protoplasm }+106 \mathrm{O}_{2}+15 \mathrm{H}^{+} \\
106 \mathrm{CO}_{2}+16 \mathrm{NO}_{3}^{-}+\mathrm{H}_{2} \mathrm{PO}_{4}^{-}+122 \mathrm{H}_{2} \mathrm{O}+17 \mathrm{H}^{+} \rightarrow \\
\text { protoplasm }+138 \mathrm{O}_{2}
\end{gathered}
$$

When ammonium is the nitrogen source, one mole oxygen is produced per mole carbon dioxide fixed. When nitrate is the nitrogen source, 1.3 moles oxygen are produced per mole carbon dioxide fixed.

The following equation describes the effect of algae on dissolved oxygen (DO) in the model.

$$
\frac{\delta}{\delta t} D O=[(1.3-0.3 \bullet P N) \bullet G-(1-F C D) \bullet R] \bullet A O C R \bullet B
$$

in which:

$F C D=$ fraction of algal metabolism recycled as dissolved organic carbon $(0 \leq F C D \leq 1)$

$A O C R=$ dissolved oxygen-to-carbon ratio in respiration $\left(2.67 \mathrm{~g} \mathrm{O}_{2} \mathrm{~g}^{-1} \mathrm{C}\right)$

The magnitude of AOCR is derived from a simple representation of the respiration process:

$$
\mathrm{CH}_{2} \mathrm{O}+\mathrm{O}_{2}=\mathrm{CO}_{2}+\mathrm{H}_{2} \mathrm{O}
$$

The quantity $(1.3-0.3 \bullet \mathrm{PN})$ is the photosynthesis ratio and expresses the molar quantity of oxygen produced per mole of carbon fixed. The photosynthesis ratio approaches unity as the algal preference for ammonium approaches unity.

\section{Organic Carbon}

Organic carbon undergoes innumerable transformations in the water column. The model carbon cycle (Figure 3-7) consists of the following elements:

- Phytoplankton production and excretion.

- Predation on phytoplankton.

- Dissolution of particulate carbon.

- Heterotrophic respiration.

- Denitrification.

- Settling. 


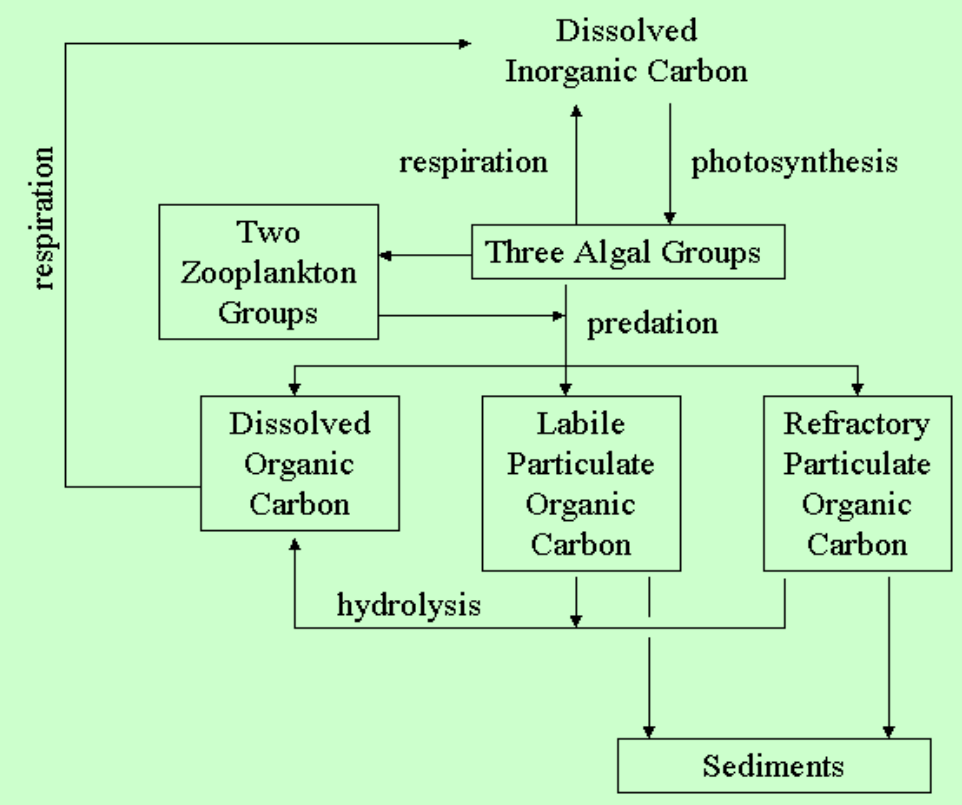

Figure 3-7. Model carbon cycle

Algal production is the primary carbon source although carbon also enters the system through external loading. Predation on algae by zooplankton and other organisms releases particulate and dissolved organic carbon to the water column. A fraction of the particulate organic carbon undergoes first-order dissolution to dissolved organic carbon. Dissolved organic carbon produced by excretion, by predation, and by dissolution is respired at a first-order rate to inorganic carbon. Particulate organic carbon that does not undergo dissolution settles to the bottom sediments.

\section{Dissolution and respiration}

Organic carbon dissolution and respiration are represented as first-order processes in which the reaction rate is proportional to concentration of the reactant. An exponential function (Figure 3-5) relates dissolution and respiration to temperature.

In the model, a Monod-like function (Monod 1949) diminishes respiration as dissolved oxygen approaches zero. As oxygen is depleted from natural systems, oxidation of organic matter is effected by the reduction of alternate oxidants. The sequence in which alternate oxidants are employed is determined by the thermodynamics of oxidation-reduction reactions. The first substance reduced in the absence of oxygen is nitrate. A representation of the denitrification reaction can be obtained by balancing standard half-cell redox reactions (Stumm and Morgan 1981):

$$
4 \mathrm{NO}_{3}^{-}+4 \mathrm{H}^{+}+5 \mathrm{CH}_{2} \mathrm{O} \rightarrow 2 \mathrm{~N}_{2}+7 \mathrm{H}_{2} \mathrm{O}+5 \mathrm{CO}_{2}
$$


Equation 3-18 describes the stoichiometry of the denitrification reaction. The kinetics of the reaction, as represented in the model, are first-order. The dissolved organic carbon respiration rate $K d o c$ is modified so that significant decay via denitrification occurs only when nitrate is freely available and dissolved oxygen is depleted (Figure 3-8). A parameter is included so that the anoxic respiration rate is slower than oxic respiration:

$$
\text { Denit }=\frac{K H o d o c}{K H o d o c+D O} \bullet \frac{\mathrm{NO}_{3}}{K H n d n+\mathrm{NO}_{3}} \bullet A A N O X \bullet K d o c
$$

in which

Denit $=$ denitrification rate of dissolved organic carbon $\left(\right.$ day $\left.^{-1}\right)$

KHodoc $=$ half-saturation concentration of dissolved oxygen required for oxic respiration $\left(\mathrm{g} \mathrm{O}_{2} \mathrm{~m}^{-3}\right)$

$K H n d n=$ half-saturation concentration of nitrate required for denitrification $\left(\mathrm{g} \mathrm{N} \mathrm{m}^{-3}\right)$

$A A N O X=$ ratio of denitrification to oxic carbon respiration rate $(0 \leq A A N O X \leq 1)$

$K d o c=$ first-order dissolved organic carbon respiration rate $\left(\right.$ day $\left.^{-1}\right)$

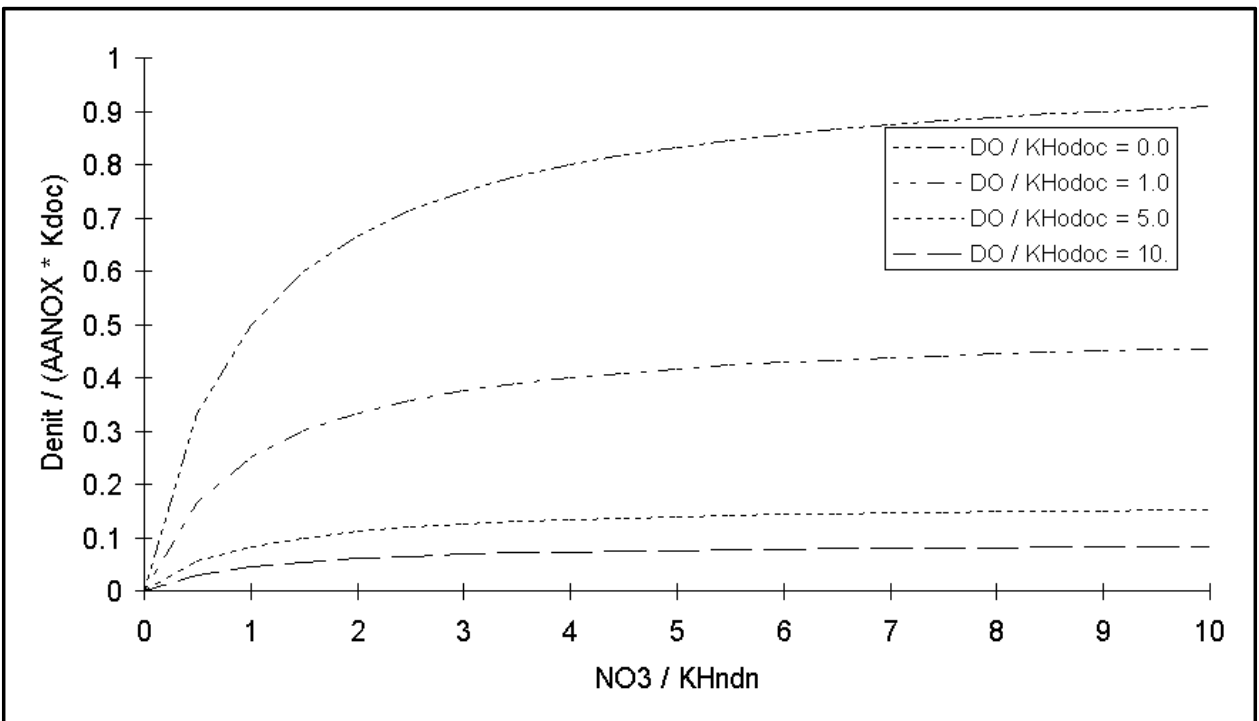

Figure 3-8. Effect of dissolved oxygen and nitrate on denitrification

\section{Dissolved organic carbon}

The complete representation of dissolved organic carbon sources and sinks in the model ecosystem is 


$$
\begin{gathered}
\frac{\delta}{\delta t} D O C=F C D \bullet R \bullet B+F C D P \bullet P R+K l p o c \bullet L P O C \\
+K r p o c \bullet R P O C-\frac{D O}{K H o d o c+D O} \bullet K d o c \bullet D O C-D E N I T \bullet D O C
\end{gathered}
$$

in which

$$
\begin{aligned}
D O C & =\text { dissolved organic carbon }\left(\mathrm{g} \mathrm{m}^{-3}\right) \\
F C D P & =\text { fraction of predation on algae released as DOC }(0<\mathrm{FCDP}<1) \\
K l p o c & =\text { dissolution rate of LPOC }\left(\mathrm{day}^{-1}\right) \\
L P O C & =\text { labile particulate organic carbon }\left(\mathrm{g} \mathrm{m}^{-3}\right) \\
K r p o c & =\text { dissolution rate of RPOC }\left(\text { day }^{-1}\right) \\
R P O C & =\text { refractory particulate organic carbon }\left(\mathrm{g} \mathrm{m}^{-3}\right)
\end{aligned}
$$

\section{Labile particulate organic carbon}

The complete representation of labile particulate organic carbon sources and sinks in the model ecosystem is

$$
\frac{\delta}{\delta t} L P O C=F C L \bullet R \bullet B+F C L P \bullet P R-K l p o c \bullet L P O C-W l \bullet \frac{\delta}{\delta z} L P O C
$$

in which

$$
\begin{aligned}
F C L & =\text { fraction of algal respiration released as LPOC }(0<\mathrm{FCL}<1) \\
F C L P & =\text { fraction of predation on algae released as LPOC }(0<\mathrm{FCLP}<1) \\
W l & =\text { settling velocity of labile particles }\left(\mathrm{m} \mathrm{day}^{-1}\right)
\end{aligned}
$$

\section{Refractory particulate organic carbon}

The complete representation of refractory particulate organic carbon sources and sinks in the model ecosystem is

$$
\frac{\delta}{\delta t} R P O C=F C R \bullet R \bullet B+F C R P \bullet P R-K r p o c \bullet R P O C-W r \bullet \frac{\delta}{\delta z} R P O C
$$

in which

$$
\begin{aligned}
F C R & =\text { fraction of algal respiration released as RPOC }(0<\mathrm{FCR}<1) \\
F C R P & =\text { fraction of predation on algae released as } \mathrm{RPOC}(0<\mathrm{FCRP}<1) \\
W r & =\text { settling velocity of refractory particles }\left(\mathrm{m} \mathrm{day}^{-1}\right)
\end{aligned}
$$




\section{Phosphorus}

The model phosphorus cycle (Figure 3-9) includes the following processes:

- Algal uptake and excretion.

- Predation.

- Hydrolysis of particulate organic phosphorus.

- Mineralization of dissolved organic phosphorus.

- Settling and resuspension.

External loads provide the ultimate source of phosphorus to the system. Dissolved phosphate is incorporated by algae during growth and released as phosphate and organic phosphorus through respiration and predation. Dissolved organic phosphorus is mineralized to phosphate. A portion of the particulate organic phosphorus hydrolyzes to dissolved organic phosphorus. The balance settles to the sediments. Within the sediments, particulate phosphorus is mineralized and recycled to the water column as dissolved phosphate.

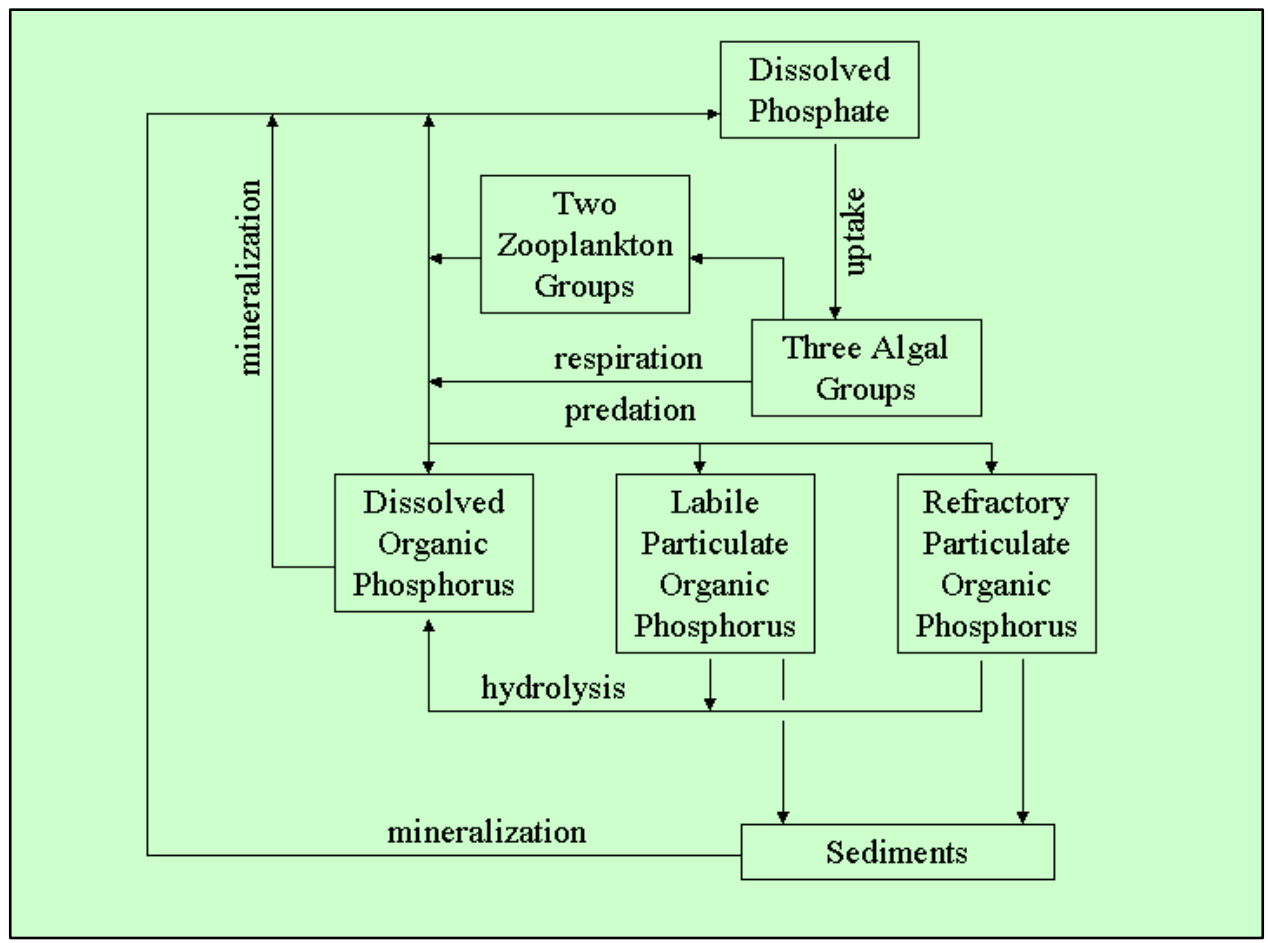

Figure 3-9. Model phosphorus cycle

\section{Hydrolysis and mineralization}

Within the model, hydrolysis is defined as the process by which particulate organic substances are converted to dissolved organic form. Mineralization is defined as the process by which dissolved organic substances are converted to dissolved inorganic form. Conversion of particulate organic phosphorus to 
phosphate proceeds through the sequence of hydrolysis and mineralization. Direct mineralization of particulate organic phosphorus does not occur.

Mineralization of organic phosphorus is mediated by the release of nucleotidase and phosphatase enzymes by bacteria (Ammerman and Azam 1985; Chrost and Overbeck 1987) and algae (Matavulj and Flint 1987; Chrost and Overbeck 1987; Boni et al. 1989). Since the algae themselves release the enzyme and since bacterial abundance is related to algal biomass, the rate of organic phosphorus mineralization is related, in the model, to algal biomass. A most remarkable property of the enzyme process is that alkaline phosphatase activity is inversely proportional to ambient phosphate concentration (Chrost and Overbeck 1987; Boni et al. 1989). Put in different terms, when phosphate is scarce, algae stimulate production of an enzyme that mineralizes organic phosphorus to phosphate. This phenomenon is simulated by relating mineralization to the algal phosphorus nutrient limitation. Mineralization is highest when algae are strongly phosphorus limited and is least when no limitation occurs.

The expression for mineralization rate is

$$
K d o p=K d p+\frac{K H p}{K H p+\mathrm{PO}_{4}} \bullet K d p a l g \bullet B
$$

in which:

$$
\begin{aligned}
K d o p & =\text { mineralization rate of dissolved organic phosphorus }\left(\text { day }^{-1}\right) \\
K d p & =\text { minimum mineralization rate }\left(\text { day }^{-1}\right) \\
K H p & =\text { half-saturation concentration for algal phosphorus uptake }\left(\mathrm{g} \mathrm{P} \mathrm{m}^{-3}\right) \\
K d p a l g & =\text { constant that relates mineralization to algal biomass }\left(\mathrm{m}^{3} \mathrm{~g}^{-1} \mathrm{C} \mathrm{day}{ }^{-1}\right)
\end{aligned}
$$

Potential effects of algal biomass and nutrient limitation on the mineralization rate are shown in Figure 3-10. When nutrient concentration greatly exceeds the half-saturation concentration for algal uptake, the rate roughly equals the minimum. Algal biomass has little influence. As nutrient becomes scarce relative to the half-saturation concentration, the rate increases. The magnitude of the increase depends on algal biomass. Factor of two to three increases are feasible.

Exponential functions (Figure 3-5) relate mineralization and hydrolysis rates to temperature. 


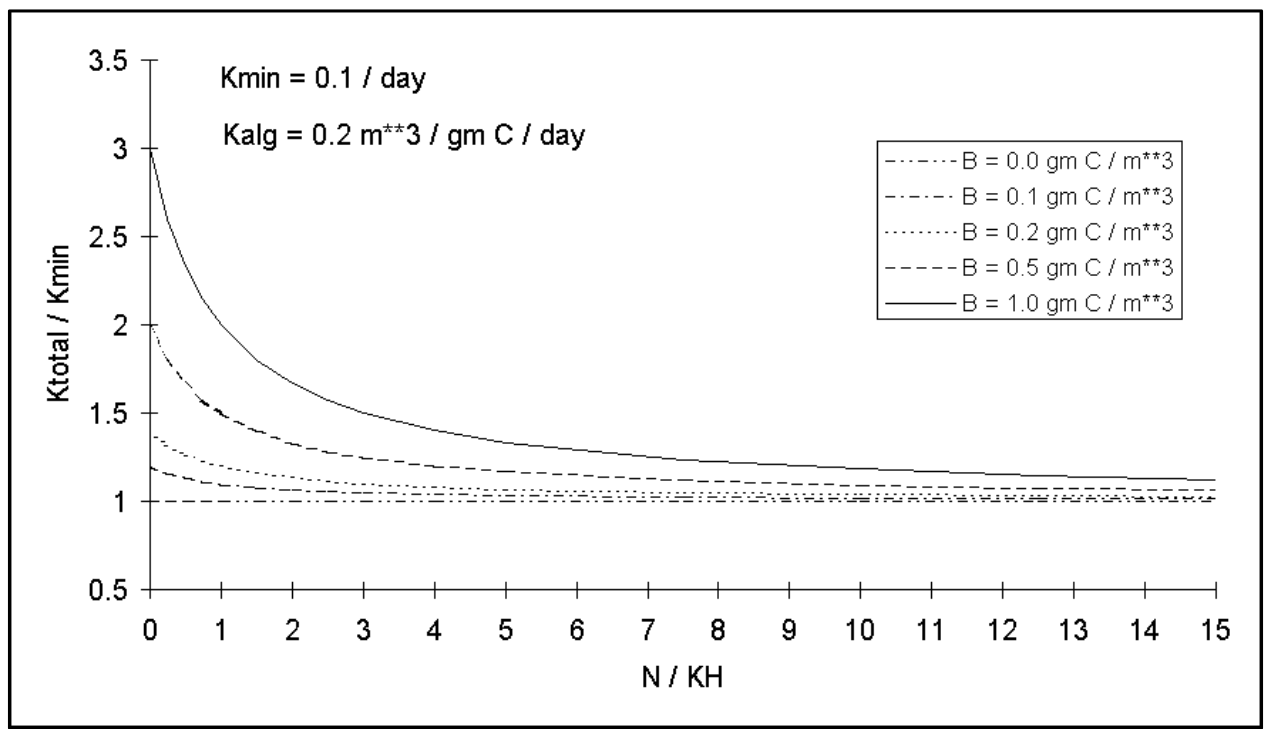

Figure 3-10. Effect of algal biomass and nutrient concentration on phosphorus mineralization

\section{Dissolved phosphate}

The mass-balance equation for dissolved phosphate is

$$
\begin{gathered}
\frac{\delta}{\delta t} \mathrm{PO}_{4}=K d o p \bullet D O P-A P C \bullet G \bullet B \\
\quad+A P C \bullet[F P I \bullet R \bullet B+F P I P \bullet P R]
\end{gathered}
$$

in which

$F P I=$ fraction of algal metabolism released as dissolved phosphate $(0 \leq F P I \leq 1)$

$F P I P=$ fraction of predation released as dissolved phosphate $(0 \leq F P I P \leq 1)$

\section{Dissolved organic phosphorus}

The mass balance equation for dissolved organic phosphorus is

$$
\begin{gathered}
\frac{\delta}{\delta t} D O P=A P C \\
\bullet(R \bullet B \bullet F P D+P R \bullet F P D P)+K l p o p \bullet L P O P \\
+K r p o p \bullet R P O P-K d o p \bullet D O P
\end{gathered}
$$

in which:

$F P D=$ fraction of algal metabolism released as $D O P(0<F P D<1)$

$F P D P=$ fraction of predation on algae released as $D O P(0<F P D P<1)$

$K l p o p=$ hydrolysis rate of $L P O P\left(\right.$ day $\left.^{-1}\right)$

Krpop $=$ hydrolysis rate of $R P O P\left(\right.$ day $\left.^{-1}\right)$ 


\section{Labile particulate organic phosphorus}

The mass balance equation for labile particulate organic phosphorus is

$$
\begin{gathered}
\frac{\delta}{\delta t} L P O P=A P C \bullet(R \bullet B \bullet F P L+P R \bullet F P L P) \\
-K l p o p \bullet L P O P-W l \bullet \frac{\delta}{\delta z} L P O P
\end{gathered}
$$

in which

$F P L=$ fraction of algal metabolism released as $L P O P(0<F P L<1)$

$F P L P=$ fraction of predation on algae released as $L P O P(0<F P L P<1)$

\section{Refractory particulate organic phosphorus}

The mass balance equation for refractory particulate organic phosphorus is

$$
\begin{gathered}
\frac{\delta}{\delta t} R P O P=A P C \bullet(R \bullet B \bullet F P R+P R \bullet F P R P) \\
- \text { Krpop } \bullet R P O P-W r \bullet \frac{\delta}{\delta z} R P O P
\end{gathered}
$$

in which

$F P R=$ fraction of algal metabolism released as $R P O P(0<F P R<1)$

$F P R P=$ fraction of predation on algae released as $R P O P(0<F P R P<1)$

\section{Nitrogen}

The model nitrogen cycle (Figure 3-11) includes the following processes:

- Algal production and metabolism.

- Predation.

- Hydrolysis of particulate organic nitrogen.

- Mineralization of dissolved organic nitrogen.

- Settling.

- Nitrification.

- Denitrification.

External loads provide the ultimate source of nitrogen to the system. Available nitrogen is incorporated by algae during growth and released as ammonium and organic nitrogen through respiration and predation. A portion of the particulate organic nitrogen hydrolyzes to dissolved organic nitrogen. The balance settles to the sediments. Dissolved organic nitrogen is mineralized to 
ammonium. In an oxygenated water column, a fraction of the ammonium is subsequently oxidized to nitrate+nitrite through the nitrification process. In anoxic water, nitrate+nitrite is lost to nitrogen gas through denitrification. Particulate nitrogen that settles to the sediments is mineralized and recycled to the water column, primarily as ammonium. Nitrate+nitrite moves in both directions across the sediment-water interface, depending on relative concentrations in the water column and sediment interstices.

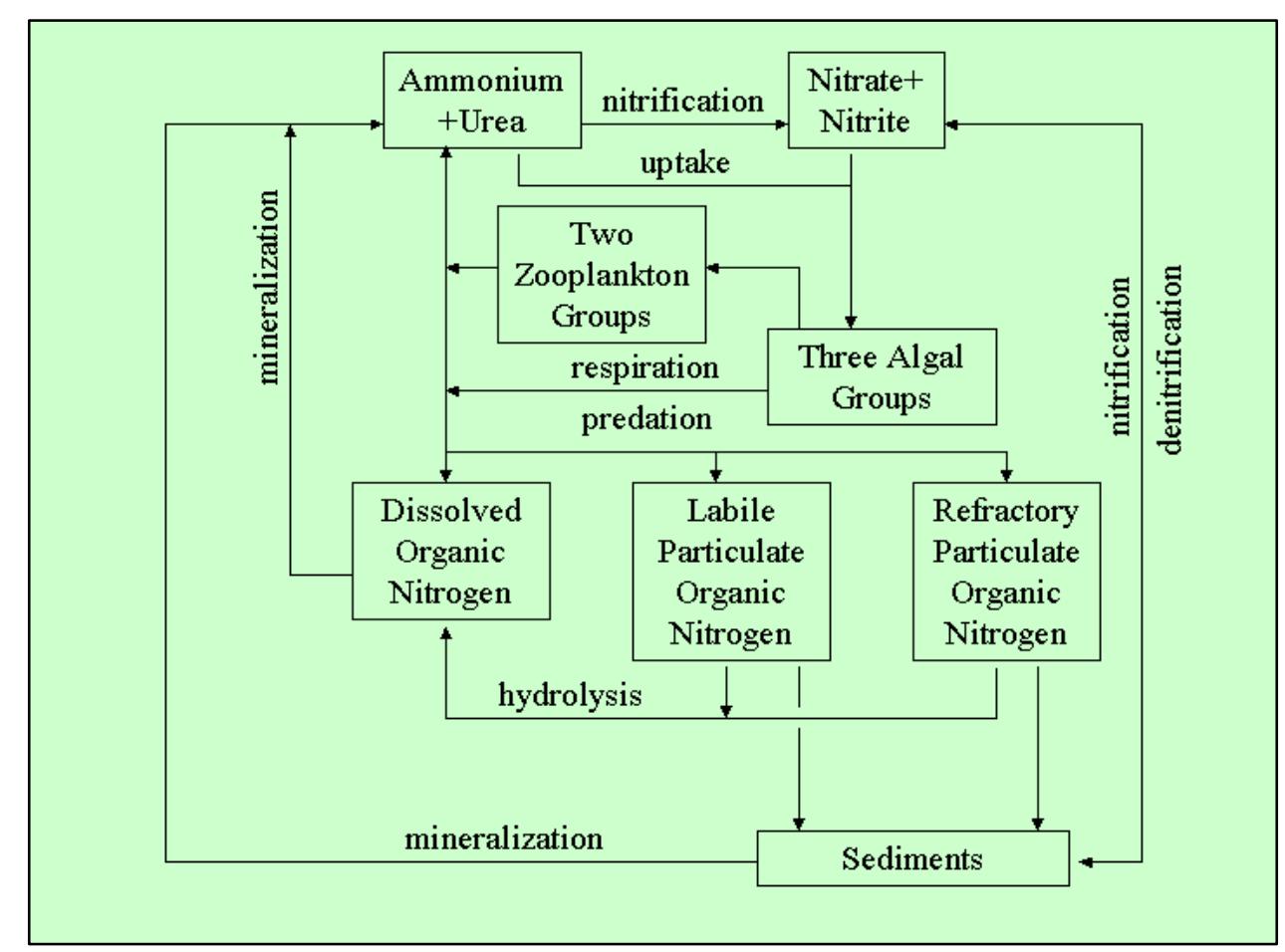

Figure 3-11. Model nitrogen cycle

\section{Nitrification}

Nitrification is a process mediated by specialized groups of autotrophic bacteria that obtain energy through the oxidation of ammonium to nitrite and oxidation of nitrite to nitrate. A simplified expression for complete nitrification (Tchobanoglous and Schroeder 1987) is

$$
\mathrm{NH}_{4}^{+}+2 \mathrm{O}_{2} \rightarrow \mathrm{NO}_{3}^{-}+\mathrm{H}_{2} \mathrm{O}+2 \mathrm{H}^{+}
$$

The simplified stoichiometry indicates that two moles of oxygen are required to nitrify one mole of ammonium into nitrate. The simplified equation is not strictly true, however. Cell synthesis by nitrifying bacteria is accomplished by the fixation of carbon dioxide so that less than two moles of oxygen are consumed per mole ammonium utilized (Wezernak and Gannon 1968).

The kinetics of complete nitrification are modeled as a function of available ammonium, dissolved oxygen, and temperature: 


$$
N T=\frac{D O}{K H o n t+D O} \cdot \frac{\mathrm{NH}_{4}}{K H n n t+\mathrm{NH}_{4}} \bullet f(T) \bullet N T m
$$

in which

$$
\begin{aligned}
N T= & \text { nitrification rate }\left(\mathrm{g} \mathrm{N} \mathrm{m}^{-3} \mathrm{day}^{-1}\right) \\
\text { KHont }= & \text { half-saturation constant of dissolved oxygen required for nitrification } \\
& \left(\mathrm{g} \mathrm{O}_{2} \mathrm{~m}^{-3}\right) \\
K H n n t= & \text { half-saturation constant of } \mathrm{NH}_{4} \text { required for nitrification }\left(\mathrm{g} \mathrm{N} \mathrm{m}^{-3}\right) \\
N T m= & \text { maximum nitrification rate at optimal temperature }\left(\mathrm{g} \mathrm{N} \mathrm{m}^{-3} \text { day }^{-1}\right)
\end{aligned}
$$

The kinetics formulation (Figure 3-12) incorporates the products of two Monod-like functions (Monod 1949). The first function diminishes nitrification at low dissolved oxygen concentration. The second function expresses the influence of ammonium concentration on nitrification. When ammonium concentration is low, relative to $K H n n t$, nitrification is proportional to ammonium concentration. For $\mathrm{NH}_{4}<<K H n n t$, the reaction is approximately first-order. (The first-order decay constant $\approx N T m / K H n n t$.) When ammonium concentration is large, relative to KHnnt, nitrification approaches a maximum rate. This formulation is based on a concept proposed by Tuffey et al. (1974). Nitrifying bacteria adhere to benthic or suspended sediments. When ammonium is scarce, vacant surfaces suitable for nitrifying bacteria exist. As ammonium concentration increases, bacterial biomass increases, vacant surfaces are occupied, and the rate of nitrification increases. The bacterial population attains maximum density when all surfaces suitable for bacteria are occupied. At this point, nitrification proceeds at a maximum rate independent of additional increase in ammonium concentration.

The optimal temperature for nitrification may be less than peak temperatures that occur in temperate waters. To allow for a decrease in nitrification at superoptimal temperature, the effect of temperature on nitrification is modeled in the Gaussian form of Equation 3-7. 


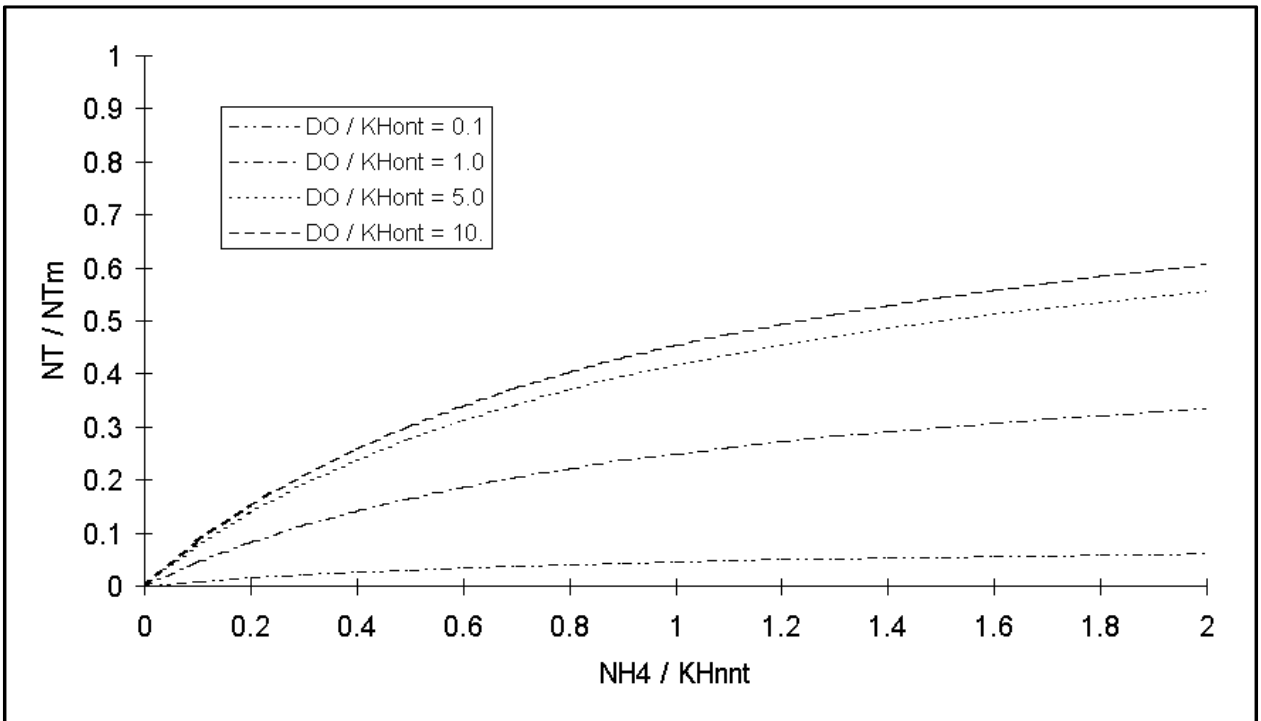

Figure 3-12. Effect of dissolved oxygen and ammonium concentrations on nitrification rate

\section{Effect of denitrification on nitrate}

The effect of denitrification on dissolved organic carbon has been described. Denitrification removes nitrate from the system in stoichiometric proportion to carbon removal:

$$
\frac{\delta}{\delta t} \mathrm{NO}_{3}=-A N D C \text { Denit DOC }
$$

in which $A N D C$ is the mass nitrate-nitrogen reduced per mass dissolved organic carbon oxidized $\left(0.933 \mathrm{~g} \mathrm{~N} \mathrm{~g}^{-1} \mathrm{C}\right)$.

\section{Nitrogen mass balance equations}

The mass-balance equation for nitrogen state variables are written by summing all previously described sources and sinks:

\section{a. Ammonium.}

$$
\begin{aligned}
\frac{\delta}{\delta t} \mathrm{NH}_{4}=A N C \bullet & {[(R \bullet F N I-P N \bullet G) \bullet B+P R \bullet F N I P] } \\
+ & K d o n \bullet D O N-N T
\end{aligned}
$$

in which

$$
\begin{aligned}
F N I & =\text { fraction of algal metabolism released as } \mathrm{NH}_{4}(0 \leq F N I \leq 1) \\
F N I P & =\text { fraction of predation released as } \mathrm{NH}_{4}(0 \leq F N I P \leq 1) \\
K d o n & =\text { dissolved organic nitrogen mineralization rate }\left(\text { day }^{-1}\right)
\end{aligned}
$$




\section{b. Nitrate+nitrite.}

$$
\begin{gathered}
\frac{\delta}{\delta t} \mathrm{NO}_{23}=-A N C \bullet(1-P N) \bullet G \bullet B+N T \\
-A N D C \bullet \text { Denit } \bullet D O C
\end{gathered}
$$

\section{c. Dissolved organic nitrogen.}

$$
\begin{aligned}
& \frac{\delta}{\delta t} D O N=A N C \bullet(R \bullet B \bullet F N D+P R \bullet F N D P) \\
+ & \text { Klpon } \bullet L P O N+K r p o n \bullet R P O N-K d o n \bullet D O N
\end{aligned}
$$

in which:

$$
\begin{aligned}
& F N D=\text { fraction of algal metabolism released as } D O N(0<F N D<1) \\
& F N D P= \text { fraction of predation on algae released as } D O N(0<F N D P<1) \\
& \text { Klpon }=\text { hydrolysis rate of } L P O N\left(\text { day }^{-1}\right) \\
& \text { Krpon }=\text { hydrolysis rate of } R P O N\left(\text { day }^{-1}\right) \\
& d . \quad \text { Labile particulate organic nitrogen } \\
& \frac{\delta}{\delta t} L P O N=A N C \bullet(R \bullet B \bullet F N L+P R \bullet F N L P) \\
& \quad-K l p o n \bullet L P O N-W l \bullet \frac{\delta}{\delta z} L P O N
\end{aligned}
$$

in which:

$F N L=$ fraction of algal metabolism released as $\operatorname{LPON}(0<F N L<1)$

$F N L P=$ fraction of predation on algae released as $L P O N(0<F N L P<1)$

\section{e. Refractory particulate organic nitrogen}

$$
\begin{gathered}
\frac{\delta}{\delta t} R P O N=A N C \bullet(R \bullet B \bullet F N R+P R \bullet F N R P) \\
-K r p o n \bullet R P O N-W r \bullet \frac{\delta}{\delta z} R P O N
\end{gathered}
$$

in which:

$$
\begin{gathered}
F N R=\text { fraction of algal metabolism released as } \operatorname{RPON}(0<F N R<1) \\
F N R P=\text { fraction of predation on algae released as } \operatorname{RPON}(0<F N R P<1)
\end{gathered}
$$




\section{Chemical Oxygen Demand}

Chemical oxygen demand is the concentration of reduced substances that are oxidized through abiotic reactions. In the model, chemical oxygen demand originates as methane released from sediments. Methane is quantified in units of oxygen demand and modeled with the following relationship:

$$
\frac{\delta}{\delta t} C O D=-\frac{D O}{K H o c o d+D O} \bullet \operatorname{Kcod} \bullet C O D
$$

in which

$C O D=$ chemical oxygen demand concentration ( $g$ oxygen-equivalents $\mathrm{m}^{-3}$ )

KHocod $=$ half-saturation concentration of dissolved oxygen required for exertion of chemical oxygen demand $\left(\mathrm{g} \mathrm{O}_{2} \mathrm{~m}^{-3}\right)$

$\operatorname{Kcod}=$ oxidation rate of chemical oxygen demand $\left(\right.$ day $\left.^{-1}\right)$

An exponential function (Figure 3-5) describes the effect of temperature on exertion of chemical oxygen demand.

\section{Dissolved Oxygen}

Sources and sinks of dissolved oxygen in the water column (Figure 3-13) include the following:

- Algal photosynthesis

- Atmospheric reaeration

- Algal respiration

- Heterotrophic respiration

- Nitrification

- Chemical oxygen demand

\section{Reaeration}

The rate of reaeration is proportional to the dissolved oxygen deficit in model segments that form the air-water interface:

$$
\frac{\delta}{\delta t} D O=\frac{K r}{\Delta z} \bullet(D O s-D O)
$$

in which:

$$
K r=\text { reaeration coefficient }\left(\mathrm{m} \mathrm{day}^{-1}\right)
$$


$\Delta z=$ model layer thickness (m)

$D O s=$ dissolved oxygen saturation concentration $\left(\mathrm{g} \mathrm{O}_{2} \mathrm{~m}^{-3}\right)$

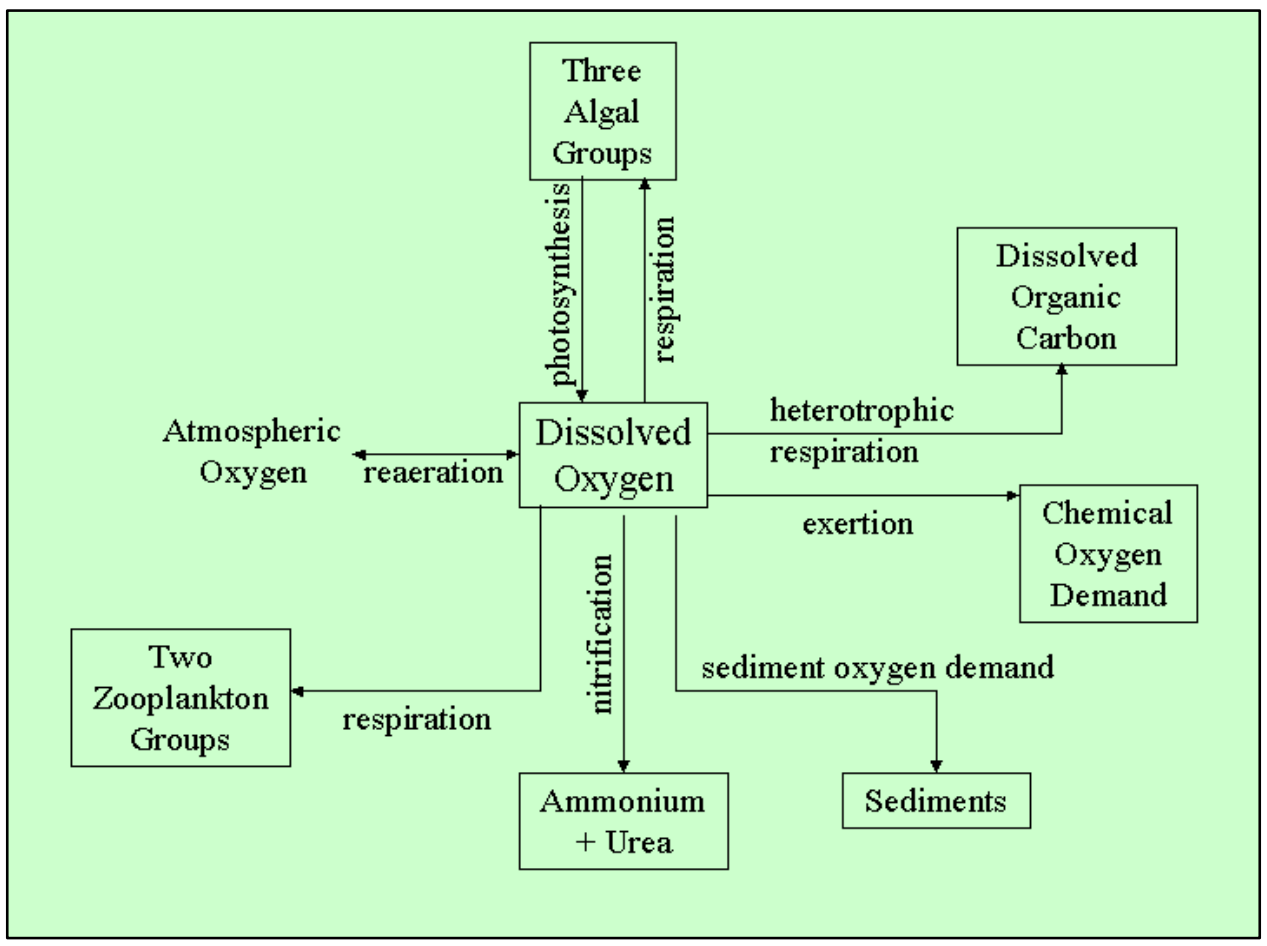

Figure 3-13. Dissolved oxygen sources and sinks

In free-flowing streams, the reaeration coefficient depends largely on turbulence generated by bottom shear stress (O'Connor and Dobbins 1958). In lakes and coastal waters, however, wind effects may dominate the reaeration process (O'Connor 1983). For Lake Washington, a relationship for wind-driven gas exchange (Hartman and Hammond 1985) was employed:

$$
K r=\text { Areaer } \bullet R v \bullet W m s^{1.5}
$$

in which

$$
\begin{aligned}
\text { Areaer }= & \text { empirical constant }(\approx 0.1) \\
R v= & \text { ratio of kinematic viscosity of pure water at } 20{ }^{\circ} \mathrm{C} \text { to kinematic } \\
& \text { viscosity of water at specified temperature and salinity } \\
W m s= & \text { wind speed measured at } 10 \mathrm{~m} \text { above water surface }\left(\mathrm{m} \mathrm{s}^{-1}\right)
\end{aligned}
$$

Hartman and Hammond (1985) indicate Areaer takes the value 0.157. In the present model, Areaer is treated as a variable to allow for effects of wind sheltering, for differences in height of local wind observations, and for other factors.

An empirical function (Figure 3-14) that fits tabulated values of $R v$ is 


$$
R v=0.54+0.0233 \bullet T-0.0020 \bullet S
$$

in which $S$ is salinity (ppt).

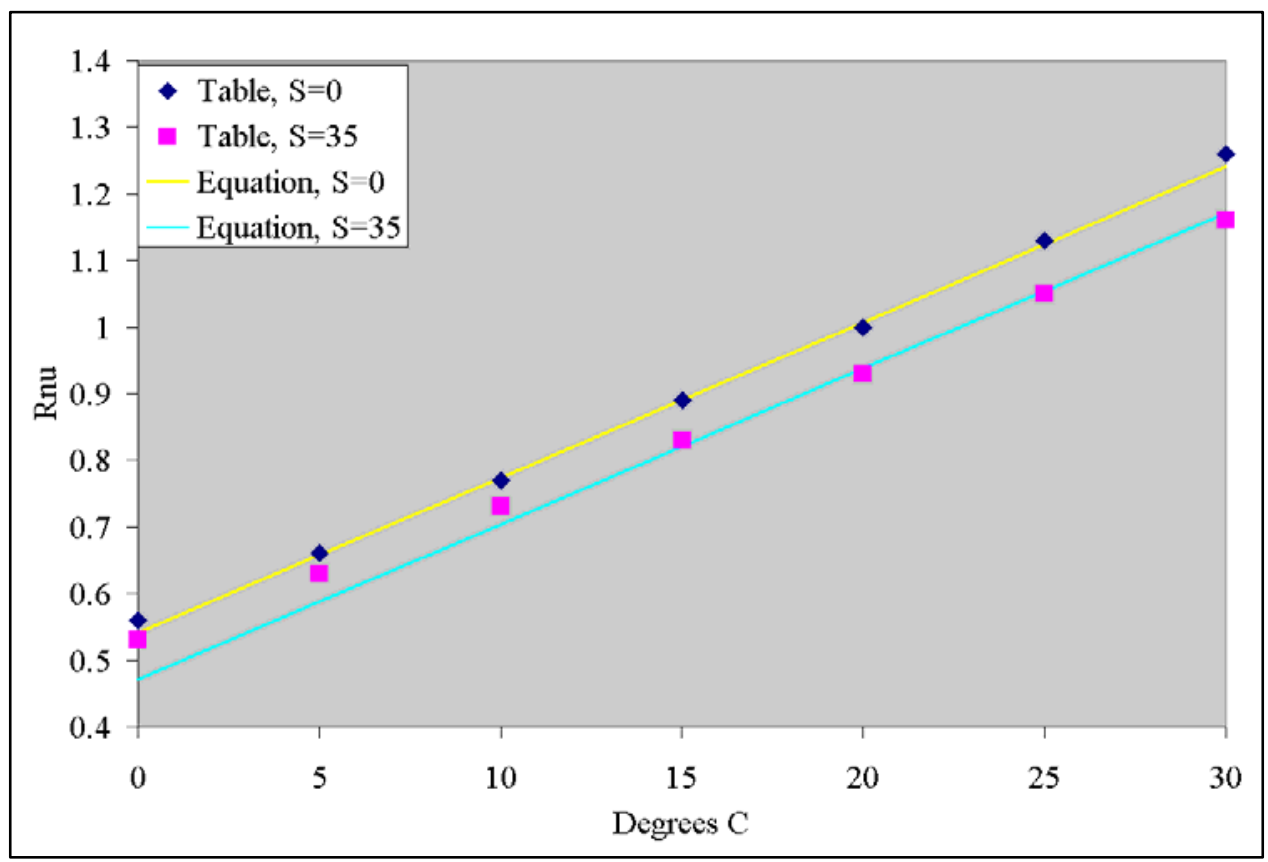

Figure 3-14. Computed and tabluated values of $R v$

Saturation dissolved oxygen concentration diminishes as temperature and salinity increase. The following empirical formula describes these effects (Genet et al. 1974):

$$
\begin{aligned}
& D O s=14.5532-0.38217 \bullet T+0.0054258 \bullet T^{2} \\
& -C L \bullet\left(1.665 \_10^{-4}-5.866 \_10^{-6} \bullet T+9.796 \_10^{-8} \bullet T^{2}\right)
\end{aligned}
$$

in which $C L$ is the chloride concentration (= salinity/1.80655).

\section{Mass balance equation for dissolved oxygen}

$$
\begin{aligned}
& \frac{\delta}{\delta t} D O=A O C R \bullet[(1.3-0.3 \bullet P N) \bullet P-(1-F C D) \bullet R] \bullet B \\
& -A O N T \bullet N T-\frac{D O}{K H o d o c+D O} \bullet A O C R \bullet K d o c \bullet D O C \\
& -\frac{D O}{K H o c o d+D O} \bullet K c o d \bullet C O D+\frac{K r}{\Delta z} \bullet(D O s-D O)
\end{aligned}
$$

in which 
$A O C R=$ oxygen-to-carbon mass ratio in production and respiration $(=2.67 \mathrm{~g}$ $\left.\mathrm{O}_{2} \mathrm{~g}^{-1} \mathrm{C}\right)$

$A O N T=$ oxygen consumed per mass ammonium nitrified $\left(=4.33 \mathrm{~g} \mathrm{O}_{2} \mathrm{~g}^{-1} \mathrm{~N}\right)$

\section{Temperature}

Computation of temperature employs a conservation of internal energy equation that is analogous to the conservation of mass equation. For practical purposes, the internal energy equation can be written as a conservation of temperature equation. The only source or sink of temperature considered is exchange with the atmosphere. Atmospheric exchange is considered proportional to the temperature difference between the water surface and a theoretical equilibrium temperature (Edinger et al. 1974):

$$
\frac{\delta}{\delta t} T=\frac{K T}{\rho \bullet C p \bullet \Delta z} \bullet(T e-T)
$$

in which

$$
\begin{aligned}
T & =\text { water temperature }\left({ }^{\circ} \mathrm{C}\right) \\
K T & =\text { Heat exchange coefficient }\left(\text { watt } \mathrm{m}^{-2}{ }^{\circ} \mathrm{C}^{-1}\right) \\
\rho & =\text { density of water }\left(1000 \mathrm{~kg} \mathrm{~m}^{-3}\right) \\
C p & =\text { specific heat of water }\left(4200 \text { watt } \mathrm{s} \mathrm{kg}^{-1}{ }^{\circ} \mathrm{C}^{-1}\right) \\
T e & =\text { equilibrium temperature }\left({ }^{\circ} \mathrm{C}\right)
\end{aligned}
$$

\section{Inorganic (Fixed) Solids}

The only kinetics transformation of fixed solids is settling:

$$
\frac{\delta}{\delta t} I S S=-W i s S \bullet \frac{\delta}{\delta z} I S S
$$

in which:

$$
\begin{aligned}
I S S & =\text { fixed solids concentration }\left(\mathrm{g} \mathrm{m}^{-3}\right) \\
W i s S & =\text { solids settling velocity }\left(\mathrm{m} \mathrm{day}^{-1}\right)
\end{aligned}
$$

\section{Parameter Values}

Model parameter evaluation is a recursive process. Parameters are selected from a range of feasible values, tested in the model, and adjusted until satisfactory agreement between predicted and observed variables is obtained. 
Ideally, the range of feasible values is determined by observation or experiment. For some parameters, however, no observations are available. Then, the feasible range is determined by parameter values employed in similar models or by the judgement of the modeler. A review of parameter values was included in documentation of the first application of this model (Cerco and Cole 1994). Parameters from the initial study were refined, where necessary, for the present model. A complete set of parameter values is provided in Table 3-2.

\begin{tabular}{|c|c|c|c|}
\hline \multicolumn{4}{|c|}{$\begin{array}{l}\text { Table 3-2 } \\
\text { Parameters in Kinetics Equations }\end{array}$} \\
\hline Symbol & Definition & Value & Units \\
\hline AANOX & ratio of anoxic to oxic respiration & 0.5 & $0 \leq \mathrm{AANOX} \leq 1$ \\
\hline ANC & nitrogen-to-carbon ratio of algae & 0.15 & $\mathrm{~g} \mathrm{~N} \mathrm{~g}^{-1} \mathrm{C}$ \\
\hline AOCR & $\begin{array}{l}\text { dissolved oxygen-to-carbon ratio in } \\
\text { respiration }\end{array}$ & 2.67 & $\mathrm{~g} \mathrm{O}_{2} \mathrm{~g}^{-1} \mathrm{C}$ \\
\hline AONT & $\begin{array}{l}\text { mass dissolved oxygen consumed per mass } \\
\text { ammonium nitrified }\end{array}$ & 4.33 & $\mathrm{~g} \mathrm{O}_{2} \mathrm{~g}^{-1} \mathrm{~N}$ \\
\hline APC & algal phosphorus-to-carbon ratio & 0.0165 & $\mathrm{gP} \mathrm{g}^{-1} \mathrm{C}$ \\
\hline Areaer & empirical constant in reaeration equation & 0.08 & \\
\hline BM & $\begin{array}{l}\text { basal metabolic rate of algae at reference } \\
\text { temperature } \mathrm{Tr}\end{array}$ & 0.03 & day $^{-1}$ \\
\hline BPR & base predation rate & $\begin{array}{l}0.22 \text { (May }- \text { Oct.) } \\
0.045 \text { otherwise }\end{array}$ & day $^{-1}$ \\
\hline $\mathrm{CChl}$ & carbon-to-chlorophyll ratio & 50 & $\mathrm{~g} \mathrm{C} \mathrm{g}^{-1} \mathrm{chl}$ \\
\hline FCD & $\begin{array}{l}\text { fraction of dissolved organic carbon produced } \\
\text { by algal metabolism }\end{array}$ & 0.0 & $0 \leq \mathrm{FCD} \leq 1$ \\
\hline FCDP & $\begin{array}{l}\text { fraction of dissolved organic carbon produced } \\
\text { by predation }\end{array}$ & 0.6 & $0 \leq \mathrm{FCDP} \leq 1$ \\
\hline $\mathrm{FCL}$ & $\begin{array}{l}\text { fraction of labile particulate carbon produced } \\
\text { by algal metabolism }\end{array}$ & 0.0 & $0 \leq \mathrm{FCL} \leq 1$ \\
\hline FCLP & $\begin{array}{l}\text { fraction of labile particulate carbon produced } \\
\text { by predation }\end{array}$ & 0.12 & $0 \leq \mathrm{FCLP} \leq 1$ \\
\hline FCR & $\begin{array}{l}\text { fraction of refractory particulate carbon } \\
\text { produced by algal respiration }\end{array}$ & 0.0 & $0 \leq \mathrm{FCR} \leq 1$ \\
\hline FCRP & $\begin{array}{l}\text { fraction of refractory particulate carbon } \\
\text { produced by predation }\end{array}$ & 0.28 & $0 \leq \mathrm{FCRP} \leq 1$ \\
\hline FND & $\begin{array}{l}\text { fraction of dissolved organic nitrogen } \\
\text { produced by algal metabolism }\end{array}$ & 0.3 & $0 \leq \mathrm{FND} \leq 1$ \\
\hline FNDP & $\begin{array}{l}\text { fraction of dissolved organic nitrogen } \\
\text { produced by predation }\end{array}$ & 0.35 & $0 \leq \mathrm{FNDP} \leq 1$ \\
\hline $\mathrm{FNI}$ & $\begin{array}{l}\text { fraction of inorganic nitrogen produced by } \\
\text { algal metabolism }\end{array}$ & 0.6 & $0 \leq \mathrm{FNI} \leq 1$ \\
\hline FNIP & $\begin{array}{l}\text { fraction of inorganic nitrogen produced by } \\
\text { predation }\end{array}$ & 0.25 & $0 \leq \mathrm{FNIP} \leq 1$ \\
\hline FNL & $\begin{array}{l}\text { fraction of labile particulate nitrogen produced } \\
\text { by algal metabolism }\end{array}$ & 0.075 & $0 \leq \mathrm{FNL} \leq 1$ \\
\hline FNLP & $\begin{array}{l}\text { fraction of labile particulate nitrogen produced } \\
\text { by predation }\end{array}$ & 0.12 & $0 \leq \mathrm{FNLP} \leq 1$ \\
\hline FNR & $\begin{array}{l}\text { fraction of refractory particulate nitrogen } \\
\text { produced by algal metabolism }\end{array}$ & 0.075 & $0 \leq \mathrm{FNR} \leq 1$ \\
\hline FNRP & $\begin{array}{l}\text { fraction of refractory particulate nitrogen } \\
\text { produced by predation }\end{array}$ & 0.28 & $0 \leq \mathrm{FNRP} \leq 1$ \\
\hline & & & (Continued \\
\hline
\end{tabular}




\begin{tabular}{|c|c|c|c|}
\hline Symbol & Definition & Value & Units \\
\hline 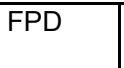 & $\begin{array}{l}\text { fraction of dissolved organic phosphorus } \\
\text { produced by algal metabolism }\end{array}$ & 0.2 & $0 \leq \mathrm{FPD} \leq 1$ \\
\hline FPDP & $\begin{array}{l}\text { fraction of dissolved organic phosphorus } \\
\text { produced by predation }\end{array}$ & 0.2 & $0 \leq \mathrm{FPDP} \leq 1$ \\
\hline FPI & $\begin{array}{l}\text { fraction of dissolved inorganic phosphorus } \\
\text { produced by algal metabolism }\end{array}$ & 0.4 & $0 \leq \mathrm{FPI} \leq 1$ \\
\hline FPIP & $\begin{array}{l}\text { fraction of dissolved inorganic phosphorus } \\
\text { produced by predation }\end{array}$ & 0.5 & $0 \leq \mathrm{FPIP} \leq 1$ \\
\hline FPL & $\begin{array}{l}\text { fraction of labile particulate phosphorus } \\
\text { produced by algal metabolism }\end{array}$ & 0.2 & $0 \leq \mathrm{FPL} \leq 1$ \\
\hline FPLP & $\begin{array}{l}\text { fraction of labile particulate phosphorus } \\
\text { produced by predation }\end{array}$ & 0.09 & $0 \leq \mathrm{FPLP} \leq 1$ \\
\hline FPR & $\begin{array}{l}\text { fraction of refractory particulate phosphorus } \\
\text { produced by algal metabolism }\end{array}$ & 0.2 & $0 \leq \mathrm{FPR} \leq 1$ \\
\hline FPRP & $\begin{array}{l}\text { fraction of refractory particulate phosphorus } \\
\text { produced by predation }\end{array}$ & 0.21 & $0 \leq \mathrm{FPRP} \leq 1$ \\
\hline Kcod & oxidation rate of chemical oxygen demand & 0.1 & day $^{-1}$ \\
\hline Kdoc & dissolved organic carbon respiration rate & 0.0075 & day $^{-1}$ \\
\hline Kdon & dissolved organic nitrogen mineralization rate & 0.018 & day $^{-1}$ \\
\hline $\mathrm{Kdp}$ & $\begin{array}{l}\text { minimum mineralization rate of dissolved } \\
\text { organic phosphorus }\end{array}$ & 0.12 & day $^{-1}$ \\
\hline Kdpalg & $\begin{array}{l}\text { constant that relates mineralization rate to } \\
\text { algal biomass }\end{array}$ & 0.2 & $\mathrm{~m}^{3} \mathrm{~g}^{-1} \mathrm{C}$ day $^{-1}$ \\
\hline $\mathrm{KHn}$ & $\begin{array}{l}\text { half-saturation concentration for nitrogen } \\
\text { uptake by algae }\end{array}$ & 0.025 & $\mathrm{~g} \mathrm{~N} \mathrm{~m}^{-3}$ \\
\hline KHndn & $\begin{array}{l}\text { half-saturation concentration of nitrate } \\
\text { required for denitrification }\end{array}$ & 0.1 & $\mathrm{~g} \mathrm{~N} \mathrm{~m}^{-3}$ \\
\hline KHnnt & $\begin{array}{l}\text { half-saturation concentration of } \mathrm{NH}_{4} \text { required } \\
\text { for nitrification }\end{array}$ & 1.0 & $\mathrm{gN} \mathrm{m}^{-3}$ \\
\hline KHocod & $\begin{array}{l}\text { half-saturation concentration of dissolved } \\
\text { oxygen required for exertion of COD }\end{array}$ & 0.5 & $\mathrm{~g} \mathrm{O}_{2} \mathrm{~m}^{-3}$ \\
\hline KHodoc & $\begin{array}{l}\text { half-saturation concentration of dissolved } \\
\text { oxygen required for oxic respiration }\end{array}$ & 0.5 & $\mathrm{~g} \mathrm{O}_{2} \mathrm{~m}^{-3}$ \\
\hline KHont & $\begin{array}{l}\text { half-saturation concentration of dissolved } \\
\text { oxygen required for nitrification }\end{array}$ & 3.0 & $\mathrm{~g} \mathrm{O}_{2} \mathrm{~m}^{-3}$ \\
\hline $\mathrm{KHp}$ & $\begin{array}{l}\text { half-saturation concentration for phosphorus } \\
\text { uptake by algae }\end{array}$ & 0.005 & $\mathrm{gP} \mathrm{m}^{-3}$ \\
\hline Klpoc & $\begin{array}{l}\text { labile particulate organic carbon dissolution } \\
\text { rate }\end{array}$ & 0.005 & day $^{-1}$ \\
\hline Klpon & $\begin{array}{l}\text { labile particulate organic nitrogen hydrolysis } \\
\text { rate }\end{array}$ & 0.08 & day $^{-1}$ \\
\hline Klpop & $\begin{array}{l}\text { labile particulate organic phosphorus } \\
\text { hydrolysis rate }\end{array}$ & 0.1 & day $^{-1}$ \\
\hline Krpoc & $\begin{array}{l}\text { refractory particulate organic carbon } \\
\text { dissolution rate }\end{array}$ & 0.001 & day $^{-1}$ \\
\hline Krpon & $\begin{array}{l}\text { refractory particulate organic nitrogen } \\
\text { hydrolysis rate }\end{array}$ & 0.001 & day $^{-1}$ \\
\hline Krpop & $\begin{array}{l}\text { refractory particulate organic phosphorus } \\
\text { hydrolysis rate }\end{array}$ & 0.001 & day $^{-1}$ \\
\hline $\mathrm{KTb}$ & $\begin{array}{l}\text { effect of temperature on basal metabolism of } \\
\text { algae }\end{array}$ & 0.032 & ${ }^{\circ} \mathrm{C}^{-1}$ \\
\hline
\end{tabular}




\begin{tabular}{|c|c|c|c|}
\hline Symbol & Definition & Value & Units \\
\hline KTcod & $\begin{array}{l}\text { effect of temperature on exertion of chemical } \\
\text { oxygen demand }\end{array}$ & 0.041 & day $^{-1}$ \\
\hline KTg1 & $\begin{array}{l}\text { effect of temperature below Topt on growth of } \\
\text { algae }\end{array}$ & 0.003 & ${ }^{\circ} \mathrm{C}^{-2}$ \\
\hline KTg2 & $\begin{array}{l}\text { effect of temperature above Topt on growth of } \\
\text { algae }\end{array}$ & 0.01 & ${ }^{\circ} \mathrm{C}^{-2}$ \\
\hline KThdr & effect of temperature on hydrolysis rates & 0.069 & ${ }^{\circ} \mathrm{C}^{-1}$ \\
\hline KTmnl & effect of temperature on mineralization rates & 0.069 & ${ }^{\circ} \mathrm{C}^{-1}$ \\
\hline KTnt1 & $\begin{array}{l}\text { effect of temperature below Tmnt on } \\
\text { nitrification }\end{array}$ & 0.001 & ${ }^{\circ} \mathrm{C}^{-2}$ \\
\hline KTnt2 & $\begin{array}{l}\text { effect of temperature above Tmnt on } \\
\text { nitrification }\end{array}$ & 0.001 & ${ }^{\circ} \mathrm{C}^{-2}$ \\
\hline NTm & $\begin{array}{l}\text { maximum nitrification rate at optimal } \\
\text { temperature }\end{array}$ & 0.075 & $\mathrm{~g} \mathrm{~N} \mathrm{~m}^{-3}$ day $^{-1}$ \\
\hline $\mathrm{P}^{\mathrm{B}} \mathrm{m}$ & maximum photosynthetic rate & 250 & $\mathrm{~g} \mathrm{C} \mathrm{g}^{-1} \mathrm{Chl} \mathrm{day}{ }^{-1}$ \\
\hline Presp & photorespiration fraction & 0.25 & $0 \leq$ Presp $\leq 1$ \\
\hline Tmnt & optimal temperature for nitrification & 30 & ${ }^{\circ} \mathrm{C}$ \\
\hline Topt & optimal temperature for growth of algae & 25 & ${ }^{\circ} \mathrm{C}$ \\
\hline Tref & reference temperature for metabolism & 20 & ${ }^{\circ} \mathrm{C}$ \\
\hline Trhdr & reference temperature for hydrolysis & 20 & ${ }^{\circ} \mathrm{C}$ \\
\hline Trmnl & reference temperature for mineralization & 20 & ${ }^{\circ} \mathrm{C}$ \\
\hline $\mathrm{Wa}$ & algal settling rate & 0.1 & $\mathrm{~m} \mathrm{day}^{-1}$ \\
\hline WI & settling velocity of labile particles & 0.8 & $\mathrm{~m} \mathrm{day}^{-1}$ \\
\hline Wiss & settling velocity of fixed solids & 1.0 & $\mathrm{~m} \mathrm{day}^{-1}$ \\
\hline $\mathrm{Wr}$ & settling velocity of refractory particles & 0.8 & $\mathrm{~m} \mathrm{day}^{-1}$ \\
\hline$\alpha$ & $\begin{array}{l}\text { initial slope of production versus irradiance } \\
\text { relationship }\end{array}$ & 8.0 & $\begin{array}{l}\mathrm{G} \mathrm{C} \mathrm{g} \mathrm{g}^{-1} \mathrm{Chl} \\
\left(\mathrm{E} \mathrm{m}^{-2}\right)^{-1}\end{array}$ \\
\hline
\end{tabular}

\section{References}

Ammerman, J., and Azam, F. (1985). "Bacterial 5'-nucleodase in aquatic ecosystems: A novel mechanism of phosphorus regeneration," Science 227, 1338-1340.

Boni, L., Carpene, E., Wynne, D., and Reti, M. (1989). "Alkaline phosphatase activity in Protogonyaulax Tamarensis," Journal of Plankton Research 11, 879-885.

Bunch, B., Cerco, C., Dortch, M., Johnson, B., and Kim, K. (2000). "Hydrodynamic and water quality model study of San Juan Bay and Estuary," ERDC TR-00-1, U.S. Army Engineer Research and Development Center, Vicksburg MS.

Cerco, C., and Bunch, B. (1997). "Passaic River tunnel diversion model study; Report 5, Water quality modeling," Technical Report HL-96-2, U.S. Army Engineer Waterways Experiment Station, Vicksburg, MS. 
Cerco, C., and Cole, T. (1994). "Three-dimensional eutrophication model of Chesapeake Bay," Technical Report EL-94-4, U.S. Army Engineer Waterways Experiment Station, Vicksburg, MS.

Cerco, C., Bunch, B., Cialone, M., and Wang, H. (1994). "Hydrodynamic and eutrophication model study of Indian River and Rehoboth Bay, Delaware," Technical Report EL-94-5, U.S. Army Engineer Waterways Experiment Station, Vicksburg, MS.

Chrost, R., and Overbeck, J. (1987). "Kinetics of alkaline phosphatase activity and phosphorus availability for phytoplankton and bacterioplankton in Lake Plubsee (north German eutrophic lake)," Microbial Ecology 13, 229-248.

Edinger, J., Brady, D., and Geyer, J. (1974). "Heat exchange and transport in the environment," Report 14, Department of Geography and Environmental Engineering, Johns Hopkins University, Baltimore, MD.

Genet, L., Smith, D., and Sonnen, M. (1974). "Computer program documentation for the Dynamic Estuary Model," U.S. Environmental Protection Agency, Systems Development Branch, Washington, DC.

Hartman, B., and Hammond, D. (1985). "Gas exchange in San Francisco Bay," Hydrobiologia 129, 59-68.

Jassby, A., and Platt, T. (1976). "Mathematical formulation of the relationship between photosynthesis and light for phytoplankton," Limnology and Oceanography 21, 540-547.

Leonard, B. (1979). "A stable and accurate convection modelling procedure based on quadratic upstream interpolation," Computer Methods in Applied Mechanics and Engineering 19, 59-98.

Matavulj, M., and Flint, K. (1987). "A model for acid and alkaline phosphatase activity in a small pond," Microbial Ecology 13, 141-158.

Monod, J. (1949). "The growth of bacterial cultures," Annual Review of Microbiology 3, 371-394.

Morel, F. (1983). Principles of aquatic chemistry. John Wiley and Sons, New York.

O'Connor, D. (1983). "Wind effects on gas-liquid transfer coefficients," Journal of the Environmental Engineering Division 190, 731-752.

O'Connor, D., and Dobbins, W. (1958). "Mechanisms of reaeration in natural streams," Transactions of the American Society of Civil Engineers 123, 641666.

Parsons, T., Takahashi, M., and Hargrave, B. (1984). Biological oceanographic processes. 3rd ed., Pergamon Press, Oxford. 
Stumm, W., and Morgan, J. (1981). Aquatic chemistry. $2^{\text {nd }}$ ed., WileyInterscience, New York.

Thomann, R., and Fitzpatrick, J. (1982). "Calibration and verification of a mathematical model of the eutrophication of the Potomac Estuary," HydroQual Inc., Mahwah, NJ.

Tchobanoglous, G., and Schroeder, E. (1987). Water quality. Addison Wesley, Reading, MA.

Tuffey, T., Hunter, J., and Matulewich, V. (1974). "Zones of nitrification," Water Resources Bulletin 10, 555-564.

Wezernak, C., and Gannon, J. (1968). "Evaluation of nitrification in streams," Journal of the Sanitary Engineering Division 94(SA5), 883-895. 


\section{Pathogens and Toxicants}

\section{Introduction}

At the request of the sponsor, a pathogen and two toxicants were added to the model code. The pathogen is activated in the present application and represents fecal coliform bacteria. The two toxicants are coded in a generalized format and are not presently activated. The general formulation is intended to provide a rapid screening tool. The formulation also provides the foundation for a more detailed application, should this be desired.

\section{Conservation of Mass Equation}

The foundation of CE-QUAL-ICM is the solution to the three-dimensional mass-conservation equation for a control volume. Control volumes correspond to cells on the model grid. CE-QUAL-ICM solves, for each volume and for each state variable, the equation:

$$
\frac{\delta V_{j} \bullet C_{j}}{\delta t}=\sum_{k=1}^{n} Q_{k} \bullet C_{k}+\sum_{k=1}^{n} A_{k} \bullet D_{k} \bullet \frac{\delta C}{\delta x_{k}}+\Sigma S_{j}
$$

in which:

$$
\begin{aligned}
V_{j} & =\text { volume of } j^{\text {th }} \text { control volume }\left(\mathrm{m}^{3}\right) \\
C_{j} & =\text { concentration in } j^{\text {th }} \text { control volume }\left(\mathrm{g} \mathrm{m}^{-3}\right) \\
t, x= & \text { temporal and spatial coordinates } \\
n= & \text { number of flow faces attached to } j^{\text {th }} \text { control volume } \\
Q_{k}= & \text { volumetric flow across flow face } k \text { of } j^{\text {th }} \text { control volume }\left(\mathrm{m}^{3} \mathrm{~s}^{-1}\right) \\
C_{k}= & \text { concentration in flow across face } k\left(\mathrm{~g} \mathrm{~m}^{-3}\right) \\
A_{k}= & \text { area of flow face } k\left(\mathrm{~m}^{2}\right) \\
D_{k}= & \text { diffusion coefficient at flow face } k\left(\mathrm{~m}^{2} \mathrm{~s}^{-1}\right) \\
S_{j}= & \text { external loads and kinetic sources and sinks in } j^{\text {th }} \text { control volume } \\
& \left(\mathrm{g} \mathrm{s}^{-1}\right)
\end{aligned}
$$


Solution of Equation 4-1 on a digital computer requires discretization of the continuous derivatives and specification of parameter values. The equation is solved using the QUICKEST algorithm (Leonard 1979) in the horizontal plane and a Crank-Nicolson scheme in the vertical direction. Discrete time-steps, determined by computational stability requirements, are approximately 15 minutes.

The remainder of this chapter is devoted to detailing the kinetics sources and sinks and to reporting parameter values. For notational simplicity, the transport terms are dropped in the reporting of kinetics formulations.

\section{Pathogen}

The pathogen undergoes temperature-dependent first-order decay:

$$
\frac{\delta}{\delta t} P A T H=-K p a t h \bullet f(T) \bullet P A T H
$$

in which:

$$
\begin{aligned}
P A T H & =\text { pathogen concentration }\left(\mathrm{mpn} 100 \mathrm{~mL}^{-1}\right) \\
K \text { path } & =\text { decay rate at reference temperature } \mathrm{T}\left(\text { day }^{-1}\right)
\end{aligned}
$$

For Lake Washington, the pathogen decay rate is 0.1 day $^{-1}$ at $20{ }^{\circ} \mathrm{C}$. The temperature function, $f(T)$, is an exponential relationship in which decay rate doubles for a $10^{\circ}$ increase in temperature (Figure 4-1).

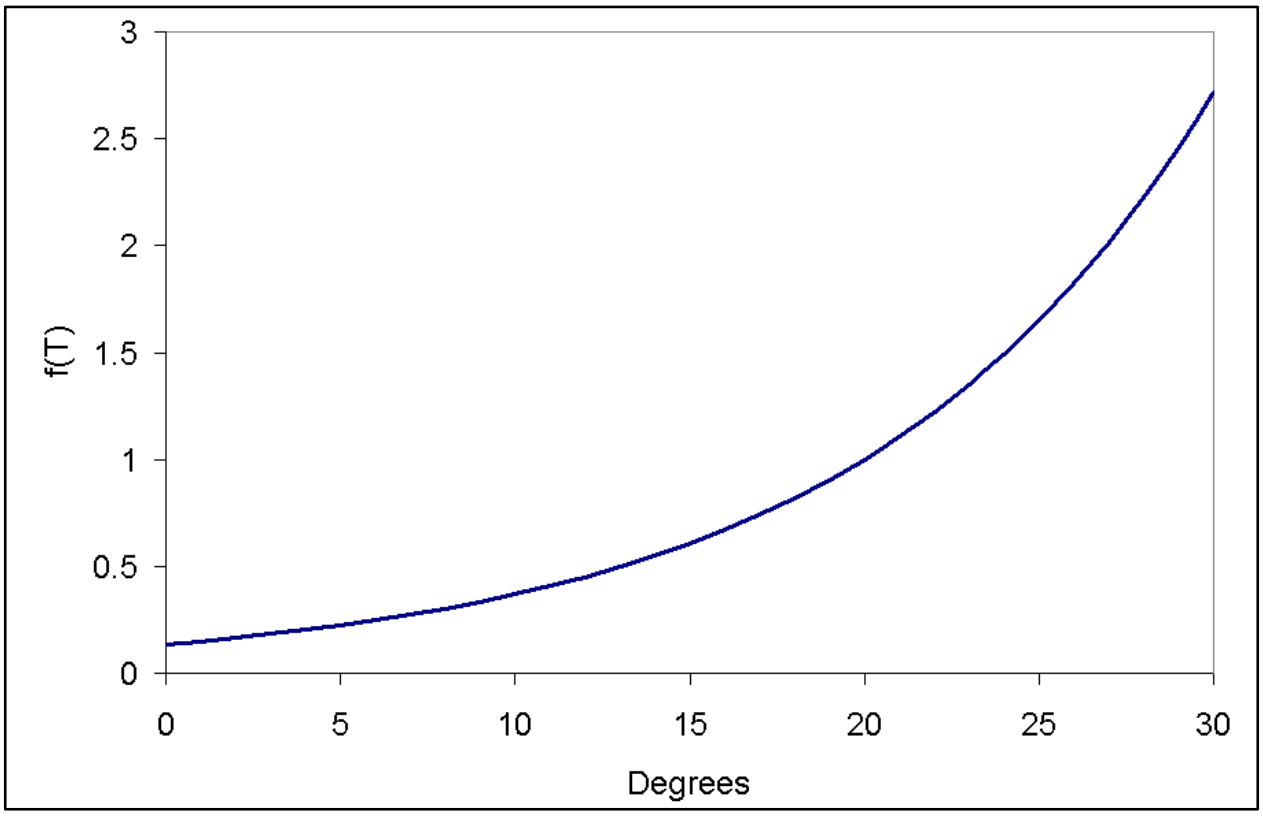

Figure 4-1. Effect of temperature on pathogen decay 


\section{Toxicants}

The two toxicants are subject to identical kinetics processes (Figure 4-2) including the following:

- Decay.

- Volatilization.

- Partitioning to solids.

- Settling.

- Burial.

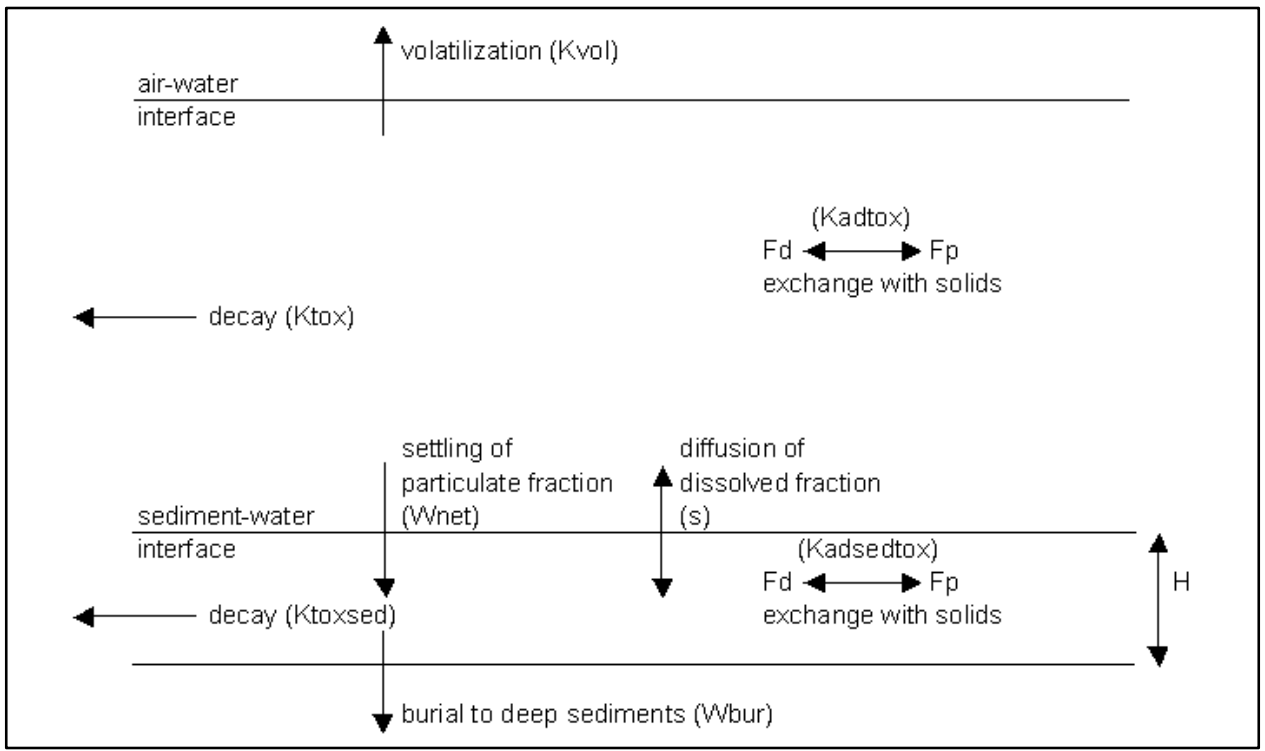

Figure 4-2. Schematic of toxicant model

Toxicant 1 partitions to inorganic solids (which can be configured to represent a metal). Toxicant 2 partitions to particulate organic carbon. Toxicant not lost through decay or volatilization may settle to the bottom sediments. Within the sediments, toxicant is subject to decay and burial. Dissolved toxicant diffuses in either direction across the sediment-water interface.

\section{Reactions in the water column}

The basic representations for the two toxicants are identical:

$$
\begin{gathered}
\frac{\delta}{\delta t} T O X=-K t o x \cdot f(T) \bullet T O X-K v o l \bullet F d \bullet \frac{T O X}{\Delta z} \\
-W s \bullet \frac{\delta}{\delta z}(F p \bullet T O X)
\end{gathered}
$$

in which: 


$$
\begin{aligned}
T O X & =\text { toxicant concentration }\left(\mathrm{g} \mathrm{m}^{-3}\right) \\
K t o x & =\text { decay rate at reference temperature } \mathrm{T}\left(\text { day }^{-1}\right) \\
K v o l & =\text { volatilization rate }\left(\mathrm{m} \mathrm{day}^{-1}\right) \\
F d & =\text { dissolved fraction of total toxicant }(0 \leq \mathrm{Fd} \leq 1) \\
F p & =\text { particulate fraction of total toxicant }(=1-\mathrm{Fd}) \\
W s & =\text { particle settling velocity }\left(\mathrm{m} \text { day }^{-1}\right) \\
\Delta z & =\text { surface layer thickness }(\mathrm{m})
\end{aligned}
$$

The decay rate increases as an exponential function of temperature. The volatilization formulation assumes that toxicant concentration in the atmosphere is negligible.

\section{Particulate and dissolved fractions}

For Toxicant 1, the particulate fraction is:

$$
F p=\frac{K A D \text { tox } 1 \bullet I S S}{1+K A D t o x 1 \bullet I S S}
$$

in which:

KADtox $1=$ Toxicant 1 partition coefficient $\left(\mathrm{m}^{3} \mathrm{~g}^{-1}\right)$

$$
I S S=\text { inorganic solids concentration }\left(\mathrm{g} \mathrm{m}^{-3}\right)
$$

For Toxicant 2, the particulate fraction is:

$$
F p=\frac{K A D \operatorname{tox} 2 \bullet(B+L P O C+R P O C)}{1+K A D \operatorname{tox} 2 \bullet(B+L P O C+R P O C)}
$$

in which:

KADtox $2=$ Toxicant 2 partition coefficient $\left(\mathrm{m}^{3} \mathrm{~g}^{-1} \mathrm{C}\right)$

$$
B=\text { algal biomass }\left(\mathrm{g} \mathrm{C} \mathrm{m}^{-3}\right)
$$

$L P O C=$ labile particulate organic carbon $\left(\mathrm{g} \mathrm{C} \mathrm{m}^{-3}\right)$

$R P O C=$ refractory particulate organic carbon $\left(\mathrm{g} \mathrm{C} \mathrm{m}^{-3}\right)$

The dissolved fraction for both toxicants is:

$$
F d=1-F p
$$




\section{Settling}

The appropriate settling velocity for Toxicant 1 is the inorganic solids settling velocity, Wiss. The settling velocities for the multiple components to which Toxicant 2 partitions may vary. The settling term is weighted by the product of the component settling velocities and concentrations:

$$
\begin{aligned}
& W s \bullet \frac{\delta}{\delta z}(F p \bullet T O X)= \\
& \frac{\delta}{\delta z} K A D t o x 2 \bullet \frac{W S a \bullet B+W S l \bullet L P O C+W S r \bullet R P O C}{1+K A D t o x 2 \bullet(B+L P O C+R P O C)} \bullet T O X
\end{aligned}
$$

in which:

$$
\begin{aligned}
W S a & =\text { algal settling velocity }\left(\mathrm{m} \mathrm{day}^{-1}\right) \\
W S l & =\text { labile particulate organic carbon settling velocity }\left(\mathrm{m} \mathrm{day}^{-1}\right) \\
W S r & =\text { refractory particulate organic carbon settling velocity }\left(\mathrm{m} \mathrm{day}^{-1}\right)
\end{aligned}
$$

\section{Reactions in the sediments}

Bed sediments are envisioned as a single, well-mixed layer (Figure 4-2). Toxicants are exchanged with the overlying water through settling of the particulate fraction and diffusion of the dissolved fraction. Within the sediments, toxicants undergo decay and burial to deep, inactive sediments. The massbalance equations for both toxicants are identical:

$$
\begin{aligned}
& H \bullet \frac{\delta}{\delta t} \text { TOXsed }=-(\text { Ktoxsed } \bullet f(T) \bullet H+\text { Wbur }) \bullet \text { TOXsed } \\
& + \text { Wnet } \bullet \text { Fpw } \bullet \text { TOXw }-s \bullet(\text { Fdsed } \bullet \text { TOXsed }- \text { Fdw } \bullet \text { TOXw })
\end{aligned}
$$

in which:

$$
H=\text { thickness of active sediment layer (m) }
$$

TOXsed $=$ bulk concentration of toxicant in sediments $\left(\mathrm{g} \mathrm{m}^{-3}\right)$

Ktoxsed $=$ decay rate in sediments $\left(\right.$ day $\left.^{-1}\right)$

$$
\begin{aligned}
W b u r & =\text { burial rate to deep, inactive sediments }\left(\mathrm{m} \mathrm{day}^{-1}\right) \\
W n e t & =\text { net settling velocity of solids into sediments }\left(\mathrm{m} \mathrm{day}^{-1}\right) \\
F p w & =\text { particulate fraction in water }(=1-F d w) \\
T O X w & =\text { concentration of toxicant in overlying water }\left(\mathrm{g} \mathrm{m}^{-3}\right) \\
s & =\text { sediment-water mass-transfer velocity }\left(\mathrm{m} \mathrm{day}^{-1}\right) \\
F d s e d & =\text { dissolved fraction in sediments }(0 \leq F d s e d \leq 1) \\
F d w & =\text { dissolved fraction in the overlying water }(0 \leq F d w \leq 1)
\end{aligned}
$$


Decay rates and partition coefficients within the sediments may vary from those specified for the water column. For Toxicant 1, the dissolved fraction within the sediments is

$$
\text { Fdsed }=\frac{1}{1+\text { KADsedtox } 1 \bullet \text { ISSsed }}
$$

in which:

KADsedtox $1=$ Toxicant 1 partition coefficient in sediments $\left(\mathrm{m}^{3} \mathrm{~g}^{-1}\right)$

ISSsed $=$ bulk inorganic solids concentration in sediments $\left(\mathrm{g} \mathrm{m}^{-3}\right)$

For Toxicant 2, the dissolved fraction is

$$
\text { Fdsed }=\frac{1}{1+\text { KADsedtox } 2 \bullet(G 1+G 2+G 3)}
$$

In which

KADsedtox $2=$ Toxicant 2 partition coefficient in sediments $\left(\mathrm{m}^{3} \mathrm{~g}^{-1} \mathrm{C}\right)$

$G 1=$ labile organic carbon concentration in sediments $\left(\mathrm{g} \mathrm{C} \mathrm{m}^{-3}\right)$

$G 2=$ refractory organic carbon concentration in sediments $\left(\mathrm{g} \mathrm{C} \mathrm{m}^{-3}\right)$

$G 3=$ inert organic carbon concentration in sediments $\left(\mathrm{g} \mathrm{C} \mathrm{m}^{-3}\right)$

The bulk sediment solids concentration is an input to the diagenesis model. The sediment carbon concentrations are computed within the sediment model. The sediment-water mass-transfer velocity is an input to the toxicant model. A small amount of recoding would allow the use of the mass-transfer velocity computed in the diagenesis model.

\section{Reference}

Leonard, B. (1979). "A stable and accurate convection modelling procedure based on quadratic upstream interpolation," Computer Methods in Applied Mechanics and Engineering 19, 59-98. 


\section{Modeling Processes at the Sediment-Water Interface}

\section{Introduction}

The predictive benthic sediment model applied to Lake Washington was first developed for use in Chesapeake Bay (DiToro and Fitzpatrick 1993).

Management of the bay required a model with two fundamental capabilities:

- Predict effects of management actions on sediment-water exchange processes.

- Predict time scale for alterations in sediment-water exchange processes.

The model (Figure 5-1, Table 5-1) is driven by net settling of organic matter from the water column to the sediments. In the sediments, the model simulates the diagenesis (decay) of the organic matter. Diagenesis produces oxygen demand and inorganic nutrients. Oxygen demand, as sulfide (in salt water) or methane (in fresh water), takes three paths out of the sediments: export to the water column as chemical oxygen demand, oxidation at the sediment-water interface as sediment oxygen demand, or burial to deep, inactive sediments. Inorganic nutrients produced by diagenesis take two paths out of the sediments: release to the water column or burial to deep, inactive sediments.

The formulation of the diagenesis model is too extensive to repeat here. Complete model documentation was provided by DiToro and Fitzpatrick (1993). More accessible documentation may presently be found in DiToro (2001). Details of the sediment model required to understand the coupling of the sediment submodel to the model of the water column are provided in this chapter. 


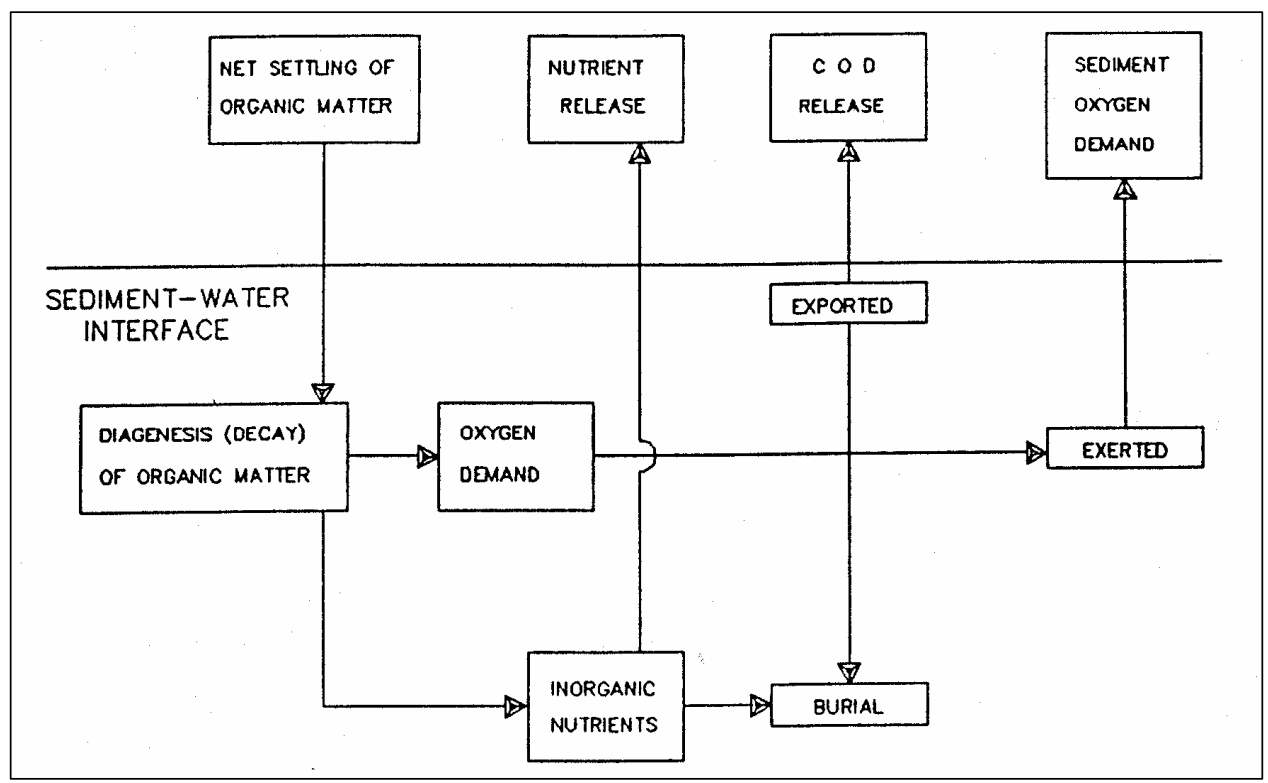

Figure 5-1. Sediment model schematic

\begin{tabular}{|c|c|}
\hline \begin{tabular}{|l} 
Table 5-1 \\
Sediment Model St
\end{tabular} & s and Fluxes \\
\hline State Variable & Sediment-Water Flux \\
\hline Temperature & \\
\hline $\mid$\begin{tabular}{||l|} 
Particulate Organic Carbon \\
\end{tabular} & Sediment Oxygen Demand \\
\hline Sulfide/Methane & Release of Chemical Oxygen Demand \\
\hline $\mid$\begin{tabular}{||l} 
Particulate Organic Nitrogen \\
Pale
\end{tabular} & \\
\hline Ammonium & Ammonium Flux \\
\hline Nitrate & Nitrate Flux \\
\hline Particulate Organic Phosphc & \\
\hline Phosphate & Phosphate Flux \\
\hline Particulate Biogenic Silica $^{1}$ & \\
\hline Available Silica $^{1}$ & Silica Flux ${ }^{1}$ \\
\hline
\end{tabular}

\section{Coupling With the Sediment Diagenesis Model}

Benthic sediments are represented as two layers with a total depth of $10 \mathrm{~cm}$ (Figure 5-2). The upper layer, in contact with the water column, may be oxic or anoxic depending on dissolved oxygen concentration in the water. The lower layer is permanently anoxic. The thickness of the upper layer is determined by the penetration of oxygen into the sediments. At its maximum thickness, the oxic layer depth is only a small fraction of the total. 


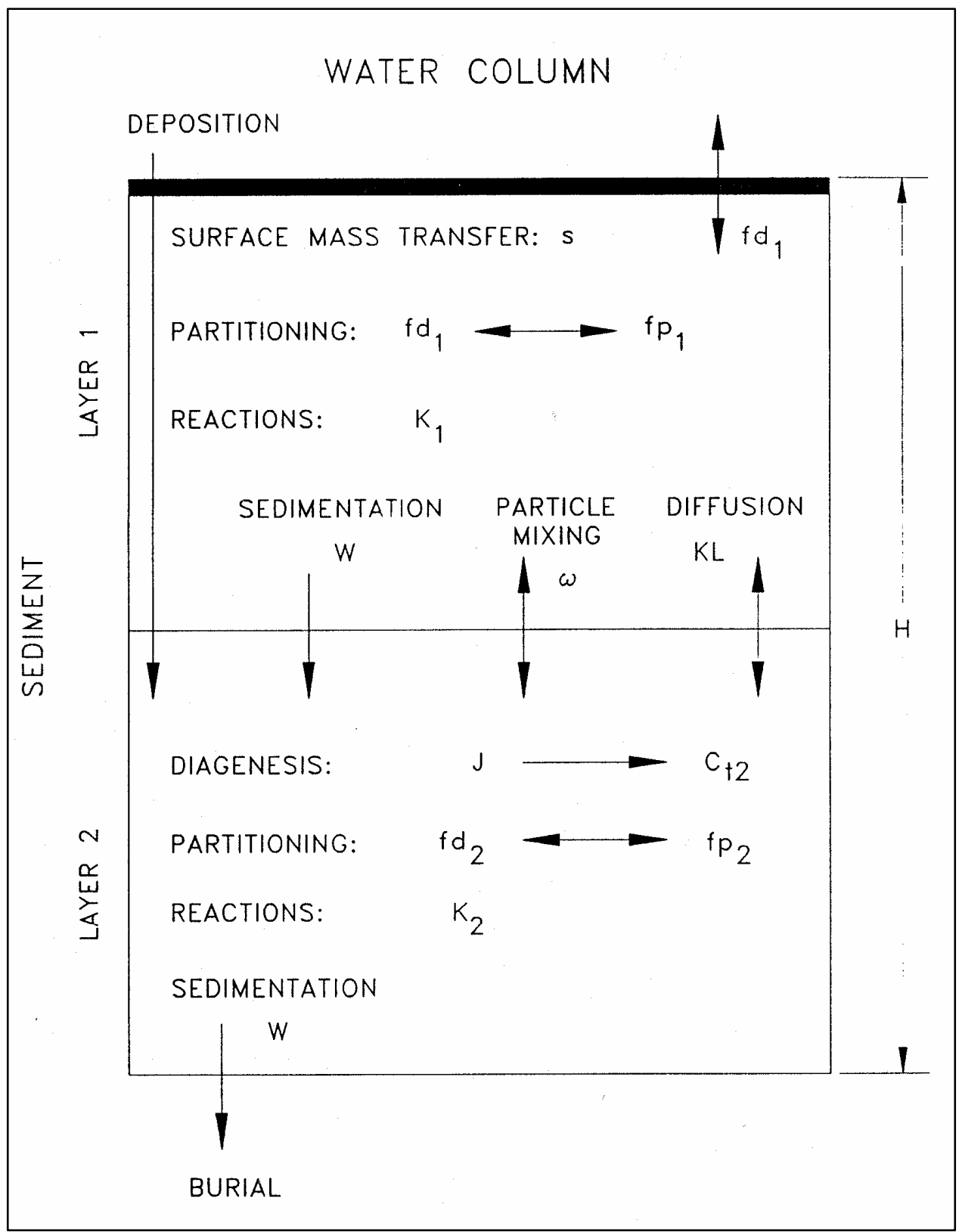

Figure 5-2. Sediment model elevation

The sediment model consists of three basic processes. The first is deposition of particulate organic matter from the water column to the sediments. Due to the negligible thickness of the upper layer, deposition proceeds from the water column directly to the lower, anoxic layer. Within the lower layer, organic matter is subject to the second basic process, diagenesis (or decay). The third basic process is flux of substances produced by diagenesis to the upper sediment layer, to the water column, and to deep, inactive sediments. The flux portion of the model is the most complex. Computation of flux requires consideration of the following:

- Reactions in both sediment layers. 
- Partitioning between particulate and dissolved fractions in both layers.

- Sedimentation from the upper to lower layer and from the lower layer to deep inactive sediments.

- Particle mixing between layers.

- Diffusion between layers.

- Mass transfer between the upper layer and the water column.

The water quality and sediment models interact on a time scale equal to the integration time-step of the water quality model. After each integration, predicted particle deposition, temperature, nutrient, and dissolved oxygen concentrations are passed from the water quality model to the sediment model. The sediment model computes sediment-water fluxes of dissolved nutrients and oxygen based on predicted diagenesis and concentrations in the sediments and water. The computed sediment-water fluxes are incorporated by the water quality model into appropriate mass balances and kinetic reactions.

\section{Deposition}

Deposition is one process that couples the model of the water column with the model of the sediments. Consequently, deposition is represented in both the sediment and water-column models. In the water column, deposition is represented with a modification of the mass-balance equation applied only to cells that interface the sediments:

$$
\frac{\delta C}{\delta t}=[\text { transport }]+[\text { kinetics }]+\frac{W S}{\Delta z} \bullet C_{u p}-\frac{W_{n e t}}{\Delta z} \bullet C
$$

in which:

$$
\begin{aligned}
C= & \begin{aligned}
\text { concentration of particulate constituent in cell above sediments } \\
\left(\mathrm{g} \mathrm{m}^{-3}\right)
\end{aligned} \\
W S= & \text { settling velocity in water column }\left(\mathrm{m} \mathrm{day}^{-1}\right) \\
\Delta z= & \text { cell thickness }(\mathrm{m}) \\
C_{u p}= & \text { constituent concentration two cells above sediments }\left(\mathrm{g} \mathrm{m}^{-3}\right) \\
W_{n e t}= & \text { net settling to sediments }\left(\mathrm{m} \mathrm{day}^{-1}\right)
\end{aligned}
$$

Net settling to the sediments may be less than or equal to settling in the water column. Sediment resuspension is implied when settling to the sediments is less than settling through the water column.

\section{Diagenesis}

Organic matter in the sediments is divided into three $\mathrm{G}$ classes or fractions, in accordance with principles established by Westrich and Berner (1984). Division 
into $\mathrm{G}$ classes accounts for differential decay rates of organic matter fractions. The G1 or labile fraction has a half-life of 20 days. The $\mathrm{G} 2$ or refractory fraction has a half-life of 1 year. The G3 or inert fraction undergoes no significant decay before burial into deep, inactive sediments. Each G class has its own massconservation equation:

$$
H \bullet \frac{\delta G i}{\delta t}=W_{n e t} \bullet f_{i} \bullet C-W \bullet G i-H \bullet K_{i} \bullet G i \bullet \theta_{i}^{(T-20)}
$$

in which:

$$
\begin{aligned}
H & =\text { total thickness of sediment layer }(\mathrm{m}) \\
G i & =\text { concentration of organic matter in G class } i\left(\mathrm{~g} \mathrm{~m}^{-3}\right) \\
f_{i} & =\text { fraction of deposited organic matter assigned to G class } i \\
W & =\text { burial rate }\left(\mathrm{m} \mathrm{day}^{-1}\right) \\
K_{i} & =\text { decay rate of } \mathrm{G} \text { class } i\left(\text { day }^{-1}\right) \\
\theta_{\mathrm{i}} & =\text { constant that expresses effect of temperature on decay of G class } i
\end{aligned}
$$

Since the G3 class is inert, $\mathrm{K}_{3}=0$.

\section{Sediment-water flux}

The exchange of dissolved substances between the sediments and water column is driven by the concentration difference between the surface sediment layer and the overlying water. Flux may be in either direction across the sediment-water interface, depending on concentration gradient. Sediment-water flux is computed within the diagenesis model as the product of concentration difference and an internally computed mass-transfer coefficient. In the water column, sediment-water exchange of dissolved substances is represented with a modification of the mass-balance equation applied only to cells that interface with bottom sediments:

$$
\frac{\delta C}{\delta t}=[\text { transport }]+[\text { kinetics }]+\frac{B E N F L X}{\Delta z}
$$

in which BENFLX is the sediment-water flux of dissolved substance $\left(\mathrm{g} \mathrm{m}^{-2}\right.$ day $\left.^{-1}\right)$.

By convention, positive fluxes are from sediment to water. Negative fluxes, including sediment oxygen demand, are from water to sediments. 


\section{Parameter Specification}

Coupling with the sediment model requires specification of net settling rates, of the $\mathrm{G}$ splits of organic matter, and of burial rates.

\section{Net settling rates}

Net settling for inorganic solids and detritus was specified as half the settling rate in the water column. The lower net settling rates, $0.5 \mathrm{~m} \mathrm{day}^{-1}$ for solids and $0.4 \mathrm{~m} \mathrm{day}^{-1}$ for detritus, were specified in an attempt to reproduce high particle concentrations observed near the bottom of the water column. Net settling for algae was the same as settling through the water column, $0.1 \mathrm{~m} \mathrm{day}^{-1}$.

\section{Assignment to $\mathbf{G}$ classes}

Upon deposition of particulate organic matter in the sediments, state variables representing particulate organic matter in the water quality model required conversion into sediment model state variables. The water quality model considered two classes of particulate organic matter: labile and refractory. The sediment model was based on three classes of organic particles: labile (G1), refractory (G2), and inert (G3). Labile particles from the water quality model were transferred directly into the G1 class in the sediment model. Refractory particles from the water quality model had to be split into G2 and G3 fractions upon entering the sediments. Algae settling directly to the sediments also required routing into sediment model state variables. Guidance for the splits was obtained from phytoplankton decomposition experiments (Westrich and Berner 1984). Planktonic particulate organic carbon was found to be 50 percent labile, 16 percent refractory, and 34 percent non-reactive (Table 5-2).

\begin{tabular}{|c|c|c|c|c|c|c|c|c|c|}
\hline \multicolumn{10}{|c|}{$\begin{array}{l}\text { Table 5-2 } \\
\text { Routing Organic Particles into Sediment Classes }\end{array}$} \\
\hline \multirow[b]{2}{*}{ WQM Variable } & \multicolumn{3}{|c|}{ Carbon } & \multicolumn{3}{|c|}{ Nitrogen } & \multicolumn{3}{|c|}{ Phosphorus } \\
\hline & $\%$ G1 & $\%$ G2 & $\%$ G3 & $\%$ G1 & \begin{tabular}{|l|}
$\%$ G2 \\
\end{tabular} & $\%$ G3 & $\%$ G1 & \% G2 & $\%$ G3 \\
\hline Labile Particles & 100 & & & 100 & & & 100 & & \\
\hline Refractory Particles & & 32 & 68 & & 32 & 68 & & 32 & 68 \\
\hline Algae & 50 & 16 & 34 & 50 & 16 & 34 & 50 & 16 & 34 \\
\hline
\end{tabular}

\section{Burial rates}

The burial rate in the sediment model, as applied to central Chesapeake Bay, is $0.25 \mathrm{~cm}$ year $^{-1}$. Kuivila and Murray (1984) cite sedimentation rates of 0.31 to $0.53 \mathrm{~cm}$ year $^{-1}$ in Lake Washington. In view of the similarity in burial rates and the minor role of this rate in the model, the burial rate of $0.25 \mathrm{~cm}_{\text {year }}{ }^{-1}$ was retained for this application. 


\section{Sediment model parameters}

With two exceptions, all parameters within the diagenesis model are exactly as derived for the original model application (DiToro and Fitzpatrick 1993). The exceptions are the phosphate partition coefficients in the surficial and subsurface sediments. The original values were halved for the Lake Washington application. Phosphorus partition coefficients were reduced from $30,000 \mathrm{~L} \mathrm{~kg}^{-1}$ to $7,500 \mathrm{~L}$ $\mathrm{kg}^{-1}$ in the surface sediments and from $100 \mathrm{~L} \mathrm{~kg}^{-1}$ to $50 \mathrm{~L} \mathrm{~kg}^{-1}$ in the subsurface sediments. In applying the diagenesis model to multiple systems, DiToro (2001) noted the phosphorus partition coefficients frequently required revision. The authors have had the same experience with applications in the present study. The partition coefficients employed in Lake Washington are low compared with the range reported by DiToro. The low partition coefficients imply Lake Washington sediments have low phosphorus retention relative to the other systems. The reduction of partition coefficients is the opposite of the authors' experience to date. The partition coefficients for freshwater systems are usually increased relative to the original estuarine application. The authors cannot speculate on the apparent difference in properties for Lake Washington.

\section{References}

DiToro, D. (2001). Sediment flux modeling. John Wiley, New York.

DiToro, D., and Fitzpatrick, J. (1993). "Chesapeake Bay sediment flux model," Contract Report EL-93-2, U.S. Army Engineer Waterways Experiment Station, Vicksburg, MS.

Kuivila, K., and Murray, J. (1984). "Organic matter diagenesis in freshwater sediments: The alkalinity and total $\mathrm{CO} 2$ balance and methane production in the sediments of Lake Washington," Limnology and Oceanography 29(6), 1218-1230.

Westrich, J., and Berner, R. (1984). "The role of sedimentary organic matter in bacterial sulfate reduction: The G model tested," Limnology and

Oceanography 29, 236-249. 


\section{Coupling with the Hydrodynamic Model}

\section{Introduction}

Modeling the physics, chemistry, and biology of Lake Washington required a pair of models. Transport processes were modeled by a three-dimensional hydrodynamic model that operated independently of the water quality model. Transport information from the hydrodynamic model was processed and stored on-line for subsequent use by the water quality model.

\section{The Hydrodynamic Model}

\section{CH3D-WES}

The CH3D-WES (Computational Hydrodynamics in Three Dimensions Waterways Experiment Station) hydrodynamic model was a substantially revised version of the CH3D model originally developed by Sheng (1986). Model formulation was based on principles expressed by the equations of motion, conservation of volume, and conservation of mass. Quantities computed by the model included three-dimensional velocities, surface elevation, vertical viscosity and diffusivity, temperature, and density.

\section{Computational grid}

The basic equations of CH3D-WES were solved via the finite-difference method. The finite-difference solution algorithm replaced continuous derivatives in the governing differential equations with ratios of discrete quantities. Solutions to the hydrodynamics were obtained using 1-minute intervals for the discrete time-steps. The spatial continuum of the lake was divided into a grid of discrete cells. To achieve close conformance of the grid to lake geometry, cells were represented in curvilinear rather than rectangular coordinates. A z-plane grid was employed in which the number of vertical layers varied depending on local depth. Velocity and diffusivity were computed on the boundaries between cells. Temperature and density were computed at the center of each cell.

The computational grid extended from the mouth of the Cedar River to the mouth of the Sammamish River, along the north-south axis, and westward to the 
Chittenden Locks (Figure 6-1). The grid contained 655 cells, roughly $0.15 \mathrm{~km}^{2}$ in area, in the surface plane. Total number of cells in the grid was 12,177. Number of cells in the vertical ranged from 1 to 41 (Figures 6-2, 6-3). Surface cells were $2.14 \mathrm{~m}$ thick at mean surface level. Variations in surface level caused by wind, runoff, and other factors were represented by computed variations in thickness of the surface layer. Thickness of all subsurface cells was fixed at $1.53 \mathrm{~m}$.

\section{Calibration and verification}

The hydrodynamic model was calibrated and verified primarily through comparison of computed and observed temperatures. Qualitative examinations of circulation and other factors were also conducted. Details of the calibration procedure were presented by Johnson et al. (2003).

\section{Linkage to the Water Quality Model}

Hydrodynamics for employment in the water quality model were produced for three years, 1995 - 1997. Each year was a single, continuous production run. Initial temperature for the first year was derived from observations. The initial hydrodynamic field was obtained from a 5-day spin-up period. Thereafter, initial conditions for each year were taken from conditions computed at the end of the previous year. Consequently, the hydrodynamic simulation was effectively a continuous 3-year run, initialized only once.

Computed flows, surface elevations, and vertical diffusivities were output at 1-hour intervals for use in the water quality model. The 1-hour hydrodynamics were determined as arithmetic means of hydrodynamics computed on a 1-minute basis. The algorithms and codes for linking the hydrodynamic and water quality models were developed over a decade ago and have been tested and proved in extensive applications since then. In every model application, the linkage is verified by comparing transport of a conservative substance computed in each model. For this application, temperatures computed by the two models were compared. In each model, daily average temperature was sampled at locations corresponding to sample stations in Lakes Washington and Union. Eighteen stations were sampled once or twice a month, from surface to bottom, over the 3year simulation period. A total of 3,468 comparisons were made between the two models and summarized in the form of a scatterplot (Figure 6-4).

Correspondence between the two models is excellent. The linear correlation coefficient of the independently computed temperatures is $\approx 0.99$ and relative error is less than 1 percent. Temperatures computed by the two models are typically within one degree of each other. A few larger differences exist. The authors attribute these primarily to differences in the specification of runoff temperatures. Minor discrepancies may also be attributed to specification of initial conditions and to methods used to obtain daily average temperature. No doubt exists that transport processes in the water quality model are identical to those in the hydrodynamic model. 


\section{References}

Johnson, B., Kim, S., Nail, G. (2003). “A three-dimensional hydrodynamic and temperature model of Lake Washington," prepared for King County Department of Natural Resources and Parks, Seattle WA.

Sheng, P. (1986). "A three-dimensional mathematical model of coastal, estuarine and lake currents using boundary-fitted grid," Report 585, ARAP Group of Titan Systems, Princeton, NJ. 


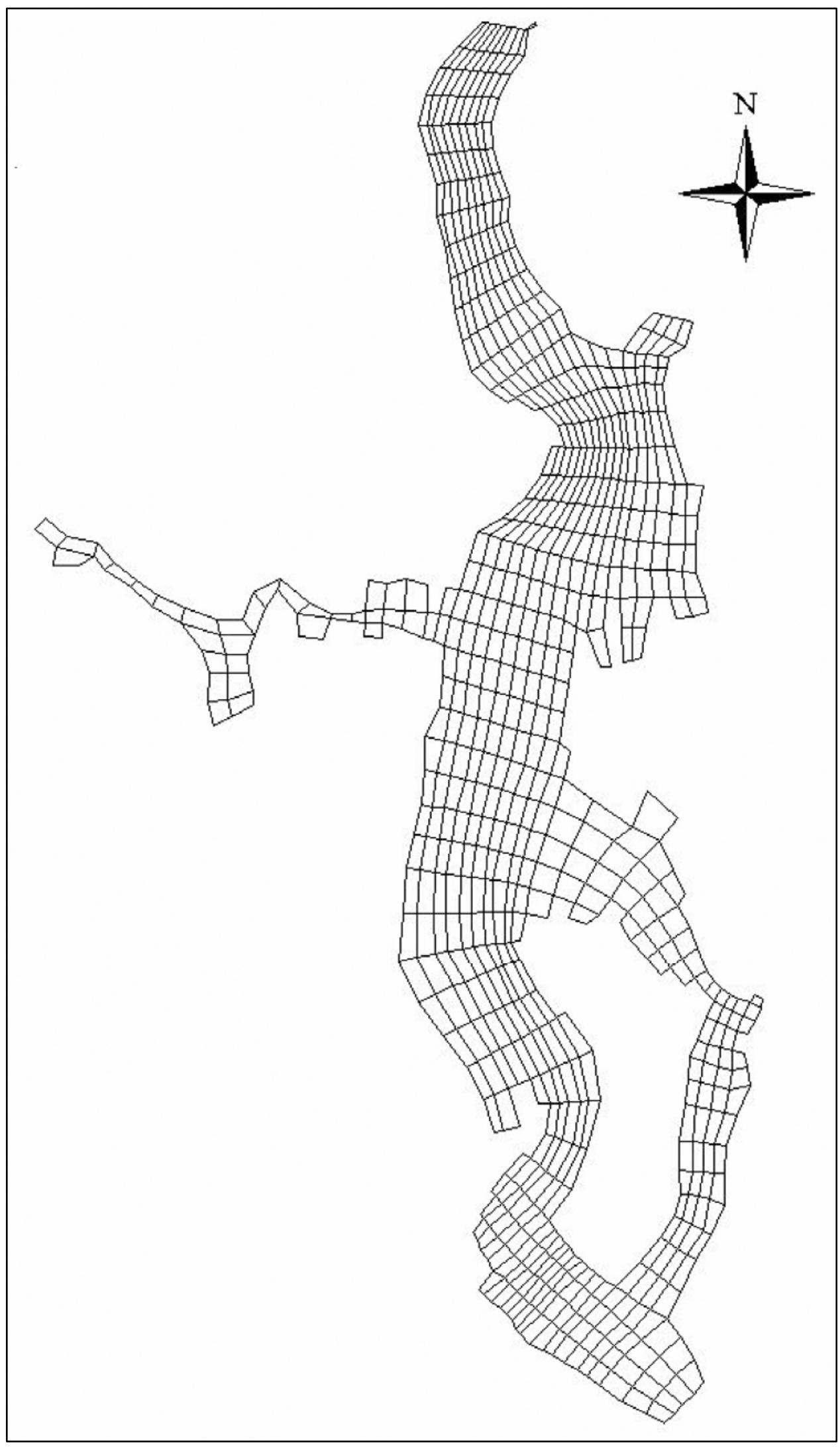

Figure 6-1. Plan view of Lake Washington grid 


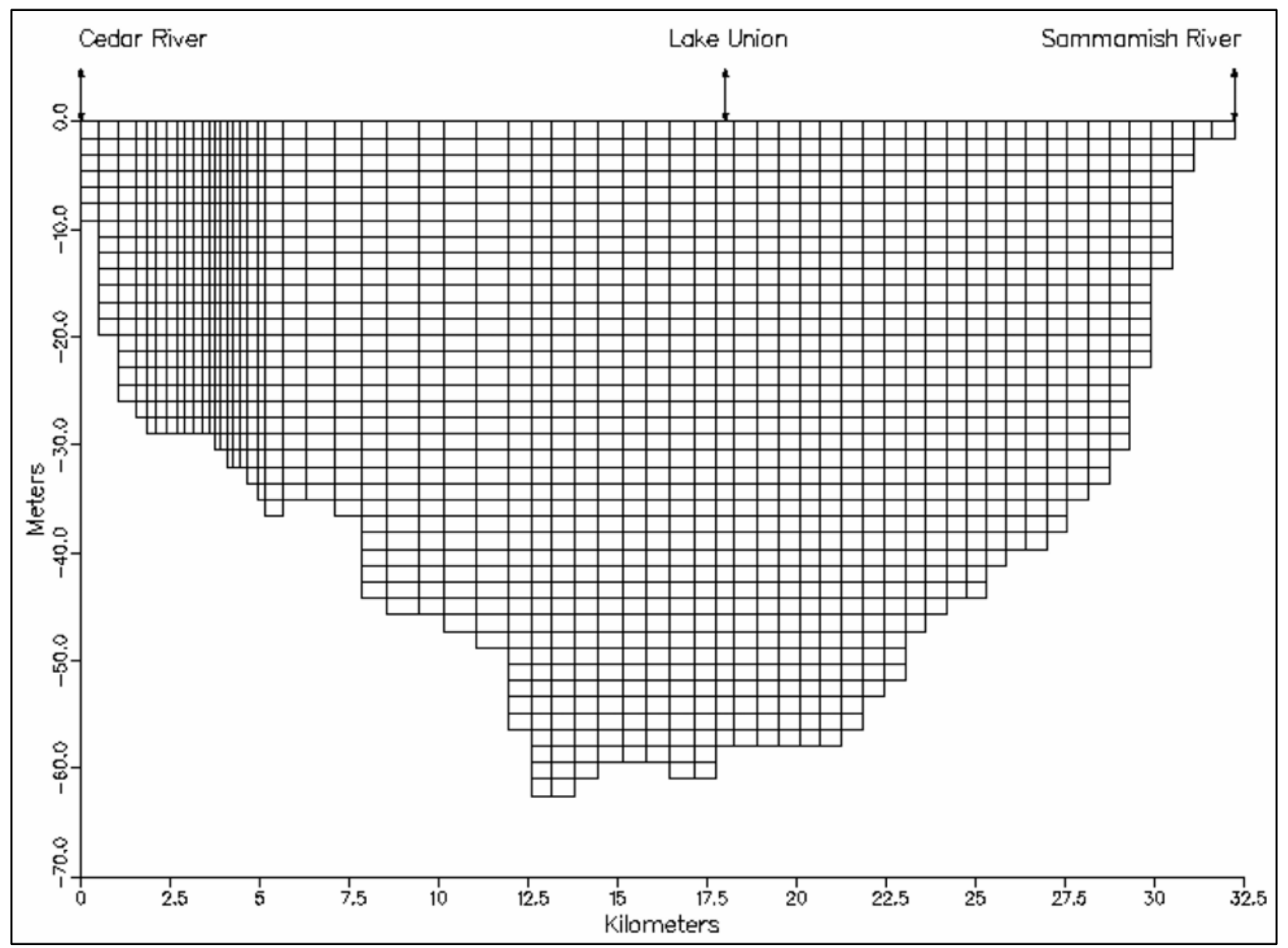

Figure 6-2. Elevation of Lake Washington grid 


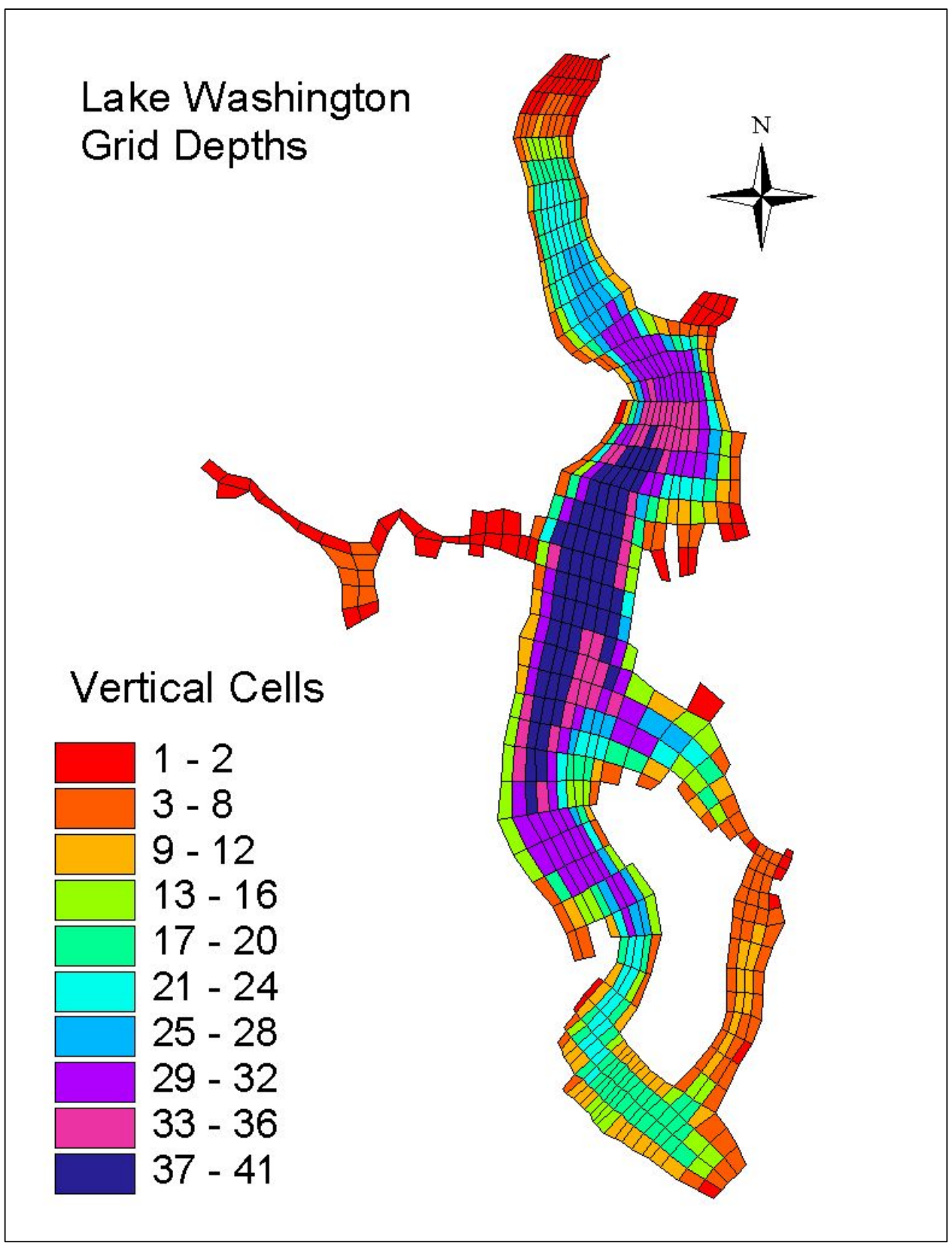

Figure 6-3. Plan view showing number of vertical cells 


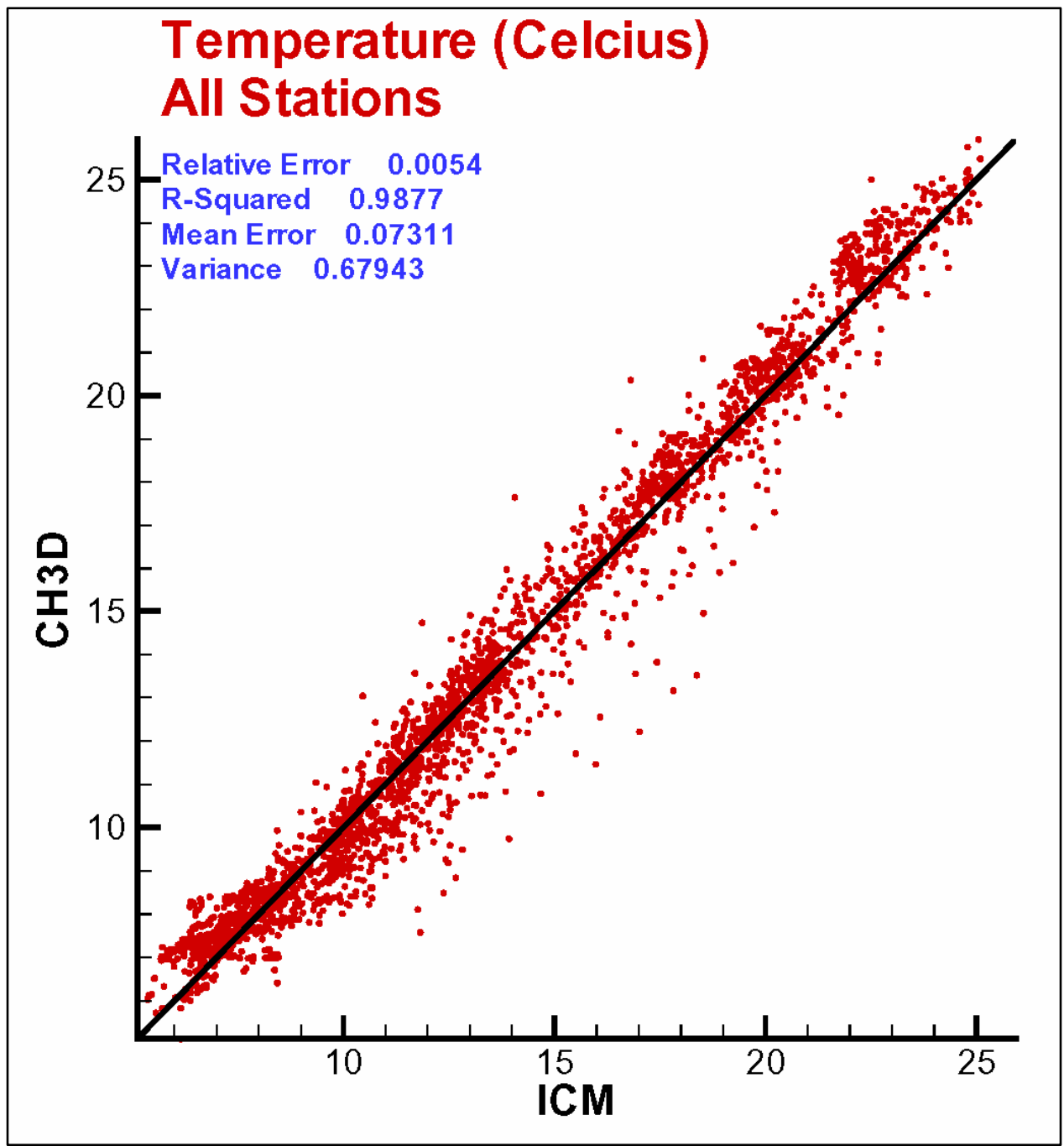

Figure 6-4. Comparison of daily average temperatures computed by hydrodynamic (CH3D) and water quality (ICM) models 


\section{Observation-based Calibration}

\section{The Database}

The primary database for calibration of the model was derived from a monitoring program conducted by King County Department of Parks and Natural Resources (KCDPNR). Observations collected at thirteen stations in Lake Washington (Figure 7-1) and five stations in Lake Union (Figure 7-2) were provided in May 2001. Sampling surveys were conducted once or twice per month and sometimes extended over a multiday period. For most constituents, observations were collected at multiple depths in the water column. Depth interval varied. Usually a sample was collected at the 1-m depth. Thereafter, samples were collected at intervals of 4 to $20 \mathrm{~m}$ with smaller increments closer to the surface. Fecal coliform were sampled at the surface only. For chlorophyll, the predominant observations consisted of a single sample integrated over the Secchi depth. At one deep site, Station 852, vertical chlorophyll profiles were occasionally collected.

Observed quantities relevant to the model are listed in Table 7-1. Total chlorophyll and phaeophytin observations were reported. Phaeophytin was subtracted from total chlorophyll to obtain viable chlorophyll for comparison with the modeled quantity. Observed disk visibility was related to modeled light attenuation through a relationship attributed to Poole and Atkins (Walker 1982):

$$
K e \cdot D V=\kappa
$$

in which:

$$
\begin{aligned}
K e & =\text { diffuse attenuation coefficient }\left(\mathrm{m}^{-1}\right) \\
D V & =\text { disk visibility }(\mathrm{m}) \\
\kappa & =\text { empirical constant }
\end{aligned}
$$

The value 1.86 was assigned to $\kappa$ based on the median value observed in clear lakes (Koenings and Edmundson 1991).

Reporting detection limit (RDL) and method detection limit (MDL) were noted in the database (Table 7-1). The RDL was the minimum concentration of 
an analyte that can be reliably quantified. The MDL was the minimum concentration of an analyte that can be detected. Values less than MDL were omitted from the database and denoted $<$ MDL. Values greater than MDL but less than RDL were reported to two significant figures. Values greater than RDL were reported to three significant figures. Omission of the $<\mathrm{MDL}$ observations created gaps in the model-data comparisons and created the impression that no information was available. The authors thought the existence of observations below MDL was important information. Observations below MDL were plotted as MDL in subsequent model-data comparisons.

\begin{tabular}{|l|l|l||}
\hline $\begin{array}{l}\text { Table 7-1 } \\
\text { Observed Constituents }\end{array}$ & RDL & MDL \\
\hline \hline Constituent & & \\
\hline \hline Temperature, ${ }^{\circ} \mathrm{C}$ & & \\
\hline Dissolved Oxygen, $\mathrm{g} \mathrm{m}^{-3}$ & 0.04 & 0.02 \\
\hline Ammonium, $\mathrm{g} \mathrm{N} \mathrm{m}^{-3}$ & 0.1 & 0.05 \\
\hline Nitrate+Nitrite, $\mathrm{g} \mathrm{N} \mathrm{m}^{-3}$ & 0.1 & 0.05 \\
\hline Total Nitrogen, $\mathrm{g} \mathrm{N} \mathrm{m}^{-3}$ & 0.005 & 0.002 \\
\hline Ortho Phosphorus, $\mathrm{g} \mathrm{P} \mathrm{m}^{-3}$ & 0.01 & 0.005 \\
\hline Total Phosphorus, $\mathrm{g} \mathrm{P} \mathrm{m}^{-3}$ & 0.05 & 0.01 \\
\hline Chlorophyll, $\mathrm{mg} \mathrm{m}^{-3}$ & & \\
\hline Disk Visibility, $\mathrm{m}$ & & \\
\hline Fecal Coliform, ${\mathrm{mpn}\left(100 \mathrm{ml}^{-1}\right.}^{-1}$ & \\
\hline \hline
\end{tabular}

Roughly 50 dissolved and total organic carbon observations, collected in 2002, were provided by the sponsor. Although the observations were collected outside the simulation period, they were available for qualitative comparison with the model.

\section{Format of Model-Data Comparisons}

\section{Graphical presentation}

Time series. Time series comparisons of computed and observed quantities were completed for 18 stations in Lakes Washington and Union. Comparisons were completed at up to three depths, depending on station depth and sample protocol. Surface, middepth, and bottom were plotted at the deepest stations. Surface and bottom were plotted at stations of moderate depth. Surface only was plotted for the shallowest stations. For all substances except chlorophyll, samples were compared to model results in the cell corresponding to sample depth. Chlorophyll samples were compared to the average of the two uppermost model cells. Depth of these two cells approximated the Secchi depth over which chlorophyll samples were integrated.

Vertical profiles. Vertical profiles were plotted at three stations in Lake Union and six stations in Lake Washington. Profiles were prepared on a monthly basis. For months with one survey, observations were plotted against model 
mean for the 5-day period centered on the survey date. For months with multiple surveys, the observed mean and range were plotted against model mean for the 5day periods centered on the survey dates.

Scatterplots. Scatterplots were prepared for various model-data assemblages. In all cases, observations were compared to daily-average model computations in cells corresponding to sample depth. Comparisons were provided for 13 individual stations in Lake Washington, for all observations in Lake Washington, for all observations in Lake Union, and for all observations in Lakes Washington and Union. An assemblage was created to examine potential differences in model performance with depth. Three deep stations $(826,852,890)$ were examined over the April to October period when stratification is present. Observations and model were grouped into three depth increments:

- Surface mixed layer, layers 1 to 6 , depth $<10 \mathrm{~m}$

- Thermocline, layers 7 to 13 , depth 10 to $20 \mathrm{~m}$

- Below thermocline, layers 14 to 41 , depth $>20 \mathrm{~m}$

\section{Statistical comparisons}

Statistical summaries were prepared corresponding to the scatterplot assemblages for the following:

\section{a. Mean error.}

$$
M E=\frac{1}{N} \cdot \sum_{n=1}^{N}\left(O_{\mathrm{n}}-P_{n}\right)
$$

in which:

$$
\begin{aligned}
N & =\text { number of observations } \\
O_{n} & =n^{\text {th }} \text { observation } \\
P_{n} & =\text { computation corresponding to } n^{\text {th }} \text { observation }
\end{aligned}
$$

\section{b. Relative error.}

$$
R E=\frac{|M E|}{\left(\sum O_{n}\right) \div N}
$$

c. Variance.

$$
V A R=\left(\frac{1}{N} \cdot \sum_{n=1}^{N}\left(O_{n}-P_{n}\right)^{2}\right)-M E^{2}
$$

\section{d. Linear correlation.}




$$
r=\frac{N \cdot \sum\left(O_{n}-P_{n}\right)-\sum O_{n} \cdot \sum P_{n}}{\left[N \cdot \sum O_{n}{ }^{2}-\left(\sum O_{n}\right)^{2}\right]^{1 / 2} \cdot\left[N \cdot \sum P_{n}{ }^{2}-\left(\sum P_{n}\right)^{2}\right]^{1 / 2}}
$$

e. Below MDL. Observations below the MDL were treated with the following protocol in computing statistics. If both observation and computation were below MDL, the observation was set equal to the computation. If the observation was below MDL while the computation exceeded MDL, the observation was set to MDL.

\section{Results}

Graphical comparisons of model results were produced using Tecplot, a commercially available graphics package. Results were plotted one to a page, resulting in several thousand pages of plots. These were assembled into bookmarked PDF's (portable document format) and provided to the project sponsor. The PDF's are also available from the first author. Illustrations in this report represent a limited, especially significant, selection. Time series and vertical plots are presented for Station 852 (Figure 7-1). This centrally located station is situated in the deepest portion of the lake and coincides with the locations of studies conducted over a period of decades.

\section{Station 852}

Temperature. Surface temperature at Station 852 exhibits an annual range of $\approx 15{ }^{\circ} \mathrm{C}$ (Figure 7-3). Minimum temperature of $\approx 7^{\circ} \mathrm{C}$ occurs in late February or early March. Maximum temperature of $22{ }^{\circ} \mathrm{C}$ or higher occurs in late July or early August. Temperature fluctuations are damped, and the date of maximum temperature is delayed with increasing depth into the water column. At middepth (Figure 7-4), the annual cycle moves through $\approx 5^{\circ} \mathrm{C}$ and maximum temperature occurs in late October. At bottom (Figure 7-5), the fluctuations are damped to less than $3{ }^{\circ} \mathrm{C}$ and maximum temperature occurs in late November. The model provides excellent representation of amplitude and timing of the annual cycle although the temperatures at middepth are high by $\approx 2{ }^{\circ} \mathrm{C}$ in the latter half of the year.

The lake is vertically well-mixed from January through March (Figures 7-6 through 7-8). Surface warming commences in April, and a thermocline develops by June. A distinct surface-mixed layer may or may not be evident in June and July. By August, this feature is clearly developed. The surface-mixed layer increases in depth as the water surface cools through November. By December, mixing is nearly complete from top to bottom. The model provides an excellent representation of the vertical structure of the lake. During the summer months, the observations show a sharper thermocline and more uniform temperature below the thermocline than the model. The smoother model profile results in higher computed temperatures just below the thermocline. These were also evident in the time series plot at middepth. Extensive experiments were performed with the hydrodynamic model to try to sharpen the thermocline. Present results are the best that can be obtained. It is uncertain if the vertical 
turbulence closure scheme requires revision or if the present grid spacing, $1.5 \mathrm{~m}$, should be refined downwards.

Chlorophyll. Surface chlorophyll at Station 852 demonstrates a spring algal bloom that commences in early April and is over by the end of May (Figure 7-9). During the bloom, concentrations rise from less than $5 \mathrm{mg} \mathrm{m}^{-3}$ to more than 15 $\mathrm{mg} \mathrm{m}^{-3}$. Following the bloom, concentrations return to less than $5 \mathrm{mg} \mathrm{m}^{-3}$. Observations suggest the occurrence of an irregular, lesser bloom in late October to early November. The model performs well in representing the timing and magnitude of the spring bloom as well as the occurrence and magnitude of the fall bloom.

The predation term was found to be the key to representing the termination of the spring bloom. A piece-wise first-order predation term was used in which predation increased from 0.045 day $^{-1}$ (November-April) to 0.22 day $^{-1}$ (MayOctober). Employment of the lower rate throughout the year resulted in a spring bloom of longer duration and in summer chlorophyll concentrations roughly double observed concentrations (Figure 7-10). Computations suggest the influence of top-down control of phytoplankton during late spring and summer. Explicit representation of zooplankton will be a worthwhile improvement in the model.

Disk visibility. The model computes the light attenuation coefficient via an additive relationship:

$$
K e=a+b \cdot I S S+c \cdot C h l
$$

in which:

$$
\begin{aligned}
a= & \text { background light attenuation }\left(0.29 \mathrm{~m}^{-1}\right) \\
b= & \text { coefficient that relates extinction to fixed solids concentration } \\
& \left(0.08 \mathrm{~m}^{2} \mathrm{~g}^{-1}\right) \\
I S S= & \text { fixed (inorganic) solids }\left(\mathrm{g} \mathrm{m}^{-3}\right) \\
c= & \text { coefficient that relates extinction to chlorophyll concentration } \\
& \left(0.02 \mathrm{~m}^{2} \mathrm{mg}^{-1}\right) \\
C h l= & \text { chlorophyll concentration }\left(\mathrm{mg} \mathrm{m}^{-3}\right)
\end{aligned}
$$

Coefficients $a$ and $b$ were assigned values based on experience in other systems (Cerco and Noel in preparation). Coefficient $c$ was assigned based on a summary of observed values (Pennock 1985). Attenuation by organic solids is incorporated in the chlorophyll attenuation coefficient since organic solids are largely associated with phytoplankton. Computed extinction is converted to disk visibility, for comparison with observations, via Equation 7-1.

Background attenuation, attributed primarily to color, is a major, consistent component of computed attenuation (Figure 7-11). In the absence of any solids, disk visibility in Lake Washington would be $\approx 6 \mathrm{~m}$. Computed fixed solids vary from 0 to $\approx 1 \mathrm{~g} \mathrm{~m}^{-3}$, with highest concentrations occurring in late winter and early 
spring, coincident with maximum runoff (Figure 7-12). Fixed solids contribute $\approx 0.08 \mathrm{~m}^{-1}$ to computed light attenuation during their period of maximum concentration. They reduce disk visibility by $1.5 \mathrm{~m}$, at most. During the spring bloom, attenuation from chlorophyll rivals color as the largest contributor to the total (Figure 7-11). Chlorophyll is the major contributor to variance in light attenuation and, hence, disk visibility. The range in computed attenuation is from nearly zero to $0.3 \mathrm{~m}^{-1}$. During the bloom, chlorophyll reduces computed disk visibility by $\approx 2.5 \mathrm{~m}$.

Computed disk visibility (Figure 7-13) is virtually the inverse of computed chlorophyll. Maximum computed visibility occurs in late autumn, when chlorophyll is low and before winter runoff events. Runoff-induced solids diminish visibility by $\approx 1 \mathrm{~m}$ from November through February. Disk visibility reaches its minimum, $\approx 3 \mathrm{~m}$, in late March to early April, during the spring bloom, and hovers around $5 \mathrm{~m}$ during the summer months. The computed pattern agrees reasonably well with the observations, which show a consistent minimum coincident with the spring bloom and suggest a maximum in late autumn. The observations show a great deal of scatter about the model value and a great deal of scatter in general. The loose agreement between model and observed visibility is attributed to three factors: the inherent uncertainty in the disk visibility measure, lack of solids data for calibration of this attenuating factor, and the conversion from attenuation to disk visibility. Aside from uncertainty in the Poole and Atkins relationship, the inverse relationship transforms small variations in computed attenuation to large variations in disk visibility. The model is believed to properly represent the magnitude of disk visibility and the processes that contribute to seasonal variations in this observed quantity.

Nitrogen. The preponderance of ammonium observations at Station 852 is below MDL of $0.02 \mathrm{~g} \mathrm{~m}^{-3}$ (Figures 7-14 through 7-16). Highest concentrations are roughly double the MDL. The available observations reveal little regular temporal or vertical variability. Certainly, the model reflects the magnitude and range of the observations. The observations for the latter 2 years of the simulation hint at higher concentrations in spring, perhaps indicating zooplankton excretion following predation on the spring bloom. The model suggests a later peak, originating in predation on the summer algal population.

Although the nitrate observations at this station are sparse, the available observations here and elsewhere indicate clear temporal and spatial trends. At the surface of Station 852 (Figure 7-17), peak nitrate concentrations, $\approx 0.3 \mathrm{~g} \mathrm{~m}^{-3}$, occur in late winter and early spring. In these months, nitrate supplied by runoff lacks major internal sinks. As the water warms and days get longer, surface nitrate is taken up by phytoplankton until a minimum, $0.02 \mathrm{~g} \mathrm{~m}^{-3}$ or less, is reached in late summer. Diminished uptake in autumn coupled with increasing runoff returns surface nitrate to its maximum concentration in late winter. The model performs admirably in reproducing the magnitude and timing of the annual cycle.

Computed nitrate cycling at middepth is influenced by algal uptake and by the vertical physical structure of the lake (Figure 7-18). A minimum occurs in spring, coincident with the spring bloom (Figure 7-19). Thereafter, nitrate concentration increases, driven by sequential hydrolysis of organic nitrogen and 
nitrification of ammonium and, perhaps, by diffusion from below. A second minimum occurs in late autumn, following fall overturn, when nitrate-depleted surface water is mixed downwards. Nitrate again increases, due to runoff, until the recurrence of the spring bloom. Available data indicate the model is performing well in reproducing the annual cycle at middepth, especially the rapid decrease in nitrate following fall overturn.

Computed nitrate concentration near the bottom (Figure 7-20) hints at an annual cycle, but the phenomenon is difficult to verify. The model profile (Figure 7-18) indicates that nitrate is lower immediately above the bottom than near middepth from May through December. This shape is sometimes apparent in the observations but not as pronounced as in the model. Overall, computed concentrations in the model are lower than the available observations. Observations range from $\approx 0.3$ to $0.4 \mathrm{~g} \mathrm{~m}^{-3}$, while comparable computations are as much as $0.2 \mathrm{~g} \mathrm{~m}^{-3}$ lower.

Total nitrogen observed at the surface of Station 852 follows an annual pattern that closely corresponds to nitrate, which comprises a major fraction of the total (Figure 7-21). Computed cycling matches the observations well although the model oscillations are damped relative to the observations.

At middepth, observed and computed total nitrogen demonstrate similar behavior and magnitude (Figure 7-22). The total dips to an annual minimum, 0.2 to $0.3 \mathrm{~g} \mathrm{~m}^{-3}$, following the mixing of nitrate-depleted water downward during fall turnover. By late winter, total nitrogen recovers to a value that remains nearly constant until the next turnover.

At bottom, observed total nitrogen varies from 0.3 to $0.6 \mathrm{~g} \mathrm{~m}^{-3}$ with no obvious repeated cycle (Figure 7-23). The model demonstrates weak cycling with a peak in midsummer. The peak is composed of $\approx 0.1 \mathrm{~g} \mathrm{~m}^{-3}$ particulate nitrogen that settles to the bottom following the spring bloom.

Phosphorus. At the surface of Station 852, ortho-phosphorus shows annual cycling (Figure 7-24) very like nitrate. Highest concentrations occur in late winter to early spring when runoff is high and internal demand is low. Orthophosphorus is almost instantly depleted by the spring algal bloom and remains low throughout the summer. In autumn, in the absence of algal uptake, orthophosphorus recovers to its annual maximum. Observed concentrations range from below MDL $\left(0.002 \mathrm{~g} \mathrm{~m}^{-3}\right)$ to $\approx 0.02 \mathrm{~g} \mathrm{~m}^{-3}$. The model performs well in reproducing the observed magnitude and cycling.

At middepth, regular cycling of ortho-phosphorus is difficult to detect in the observations although lower values usually occur in late summer versus higher values in late winter to early spring (Figure 7-25). The observed range varies from below MDL $\left(0.002 \mathrm{~g} \mathrm{~m}^{-3}\right)$ to $\approx 0.02 \mathrm{~g} \mathrm{~m}^{-3}$. The model exhibits cycling much like nitrate at the same depth. One minimum occurs following uptake by the spring bloom. Thereafter, ortho-phosphorus recovers to an annual maximum. A second minimum occurs when phosphorus-depleted surface water is mixed downward during fall overturn. Runoff and absence of uptake create a secondary maximum prior to the demand created by the spring bloom. 
Although the model cycle is readily explainable, it is not apparent in the data. In particular, the recovery following the spring bloom is missing from the observations. This phenomenon of excess ortho-phosphorus is evident in other model applications (e.g., Cerco and Noel in preparation). The problem originates in two features of conventional phosphorus models.

In the conventional modeling approach, dissolved organic phosphorus mineralizes to ortho-phosphorus at a first-order rate regardless of demand. No mechanistic explanation is provided to explain why a fixed fraction of organic phosphorus is mineralized on a daily basis. Conventional models include no sink for ortho-phosphorus except algal uptake. Ortho-phosphorus produced in the dark by first-order decay lasts eternally.

This model addresses the issue of excess ortho-phosphorus production by relating mineralization rate to algal biomass and nutrient deficit. Mineralization is reduced when biomass is low and/or when ortho-phosphorus is abundant relative to algal requirements (see Chapter 3). In an earlier approach, DiToro and Matysik (1979) also related mineralization to algal biomass. While the supply side can be addressed by empirical formulations, demand by biota other than phytoplankton seems to be universally absent from eutrophication models. A cursory literature search indicates that heterotrophic bacteria compete with phytoplankton for phosphate (Thingstad et al. 1993) and may draw phosphate down to limiting levels (Zweifel et al. 1993). While an explicit representation of bacterial phosphorus uptake is a major undertaking, an empirical approach should be feasible. One approach is to relate phosphorus uptake to organic carbon respiration, which is a bacterial process.

On the bottom, computed ortho-phosphorus demonstrates an annual cycle that is representative of the observations (Figure 7-26). The annual minimum occurs following the autumn turnover when phosphorus-depleted water is mixed downward. Thereafter, ortho-phosphorus recovers to an annual maximum prior to the next turnover. The cycling and range, 0.01 to $0.03 \mathrm{~g} \mathrm{~m}^{-3}$, of the observations are well represented by the model.

Vertical profiles for ortho-phosphorus (Figures 7-27 through 7-29) provide a different perspective but indicate the same behaviors as the time series. At the surface, the model represents the depletion of ortho-phosphorus during the late spring and summer months. Below the thermocline, however, ortho-phosphorus is trapped and forms a bulge that persists until turnover in January or February.

Observed and computed total phosphorus levels in surface waters follow a seasonal cycle (Figure 7-30). Maximum concentrations, $\approx 0.03 \mathrm{~g} \mathrm{~m}^{-3}$, occur in late winter, when runoff-induced loads are largest. Diminished loads and loss through sinking of algal detritus produce a minimum, $\approx 0.005 \mathrm{~g} \mathrm{~m}^{-3}$, in late summer.

Seasonal cycling is difficult to perceive in the observations at the middepth (Figure 7-31) and near bottom (Figure 7-32). More distinctive cycling is apparent in the model. Near-bottom, maximum computed concentrations, $\approx 0.05 \mathrm{~g} \mathrm{~m}^{-3}$, occur in late spring, following deposition of the algal bloom. Thereafter concentration tails off slowly until the winter overturn. At the overturn, computed total phosphorus declines sharply as phosphorus-depleted surface 
water is mixed with bottom water. The annual minimum, $\approx 0.02 \mathrm{~g} \mathrm{~m}^{-3}$, occurs in late winter and persists until deposition of the spring algal bloom. Cycling of computed total phosphorus at middepth is damped relative to bottom water. The predominant feature is a late-fall dip of $\approx 0.01 \mathrm{~g} \mathrm{~m}^{-3}$ as surface water is mixed downwards.

In the vertical dimension (Figures 7-33 through 7-35), cycling between wellmixed and stratified conditions is evident in the observations. Total phosphorus is well mixed from top to bottom from January through March or April. Thereafter, concentrations near the bottom increase to the highest values observed at the station, occasionally in excess of $0.05 \mathrm{~g} \mathrm{~m}^{-3}$ from August through November. Comparison with the ortho-phosphorus profiles indicates that the preponderance of the total is ortho-phosphorus, most likely released from bottom sediments.

Organic carbon. Organic carbon observations were not collected during the model application period. A limited number of observations were available from 2002. For qualitative comparison with the model, these observations were plotted on dates in 1995-1997 corresponding to the month and day of collection in 2002.

The observations suggest particulate organic carbon near the surface peaks at more than $1 \mathrm{~g} \mathrm{~m}^{-3}$ during the spring bloom (Figure 7-36). Otherwise concentrations are $\approx 0.5 \mathrm{~g} \mathrm{~m}^{-3}$. Model computations reproduce this behavior. Near the bottom, observed particulate organic carbon is $\approx 0.5 \mathrm{~g} \mathrm{~m}^{-3}$ or less (Figure 737). The observations hint at a late winter peak, but absence of a similar peak in observations from other stations suggests that the apparent pattern at Station 852 cannot be discerned from random variance. The model shows a definite seasonal signal. Near-bottom particulate organic carbon peaks in late spring when detritus from the algal bloom settles to the bottom. The computed maximum, more than $1.5 \mathrm{~g} \mathrm{~m}^{-3}$, exceeds values in the limited observations. Otherwise the computations reflect the observed magnitude and range.

Observations indicate surface dissolved organic carbon ranges from 3 to $4 \mathrm{~g}$ $\mathrm{m}^{-3}$ with the highest concentration occurring in late summer (Figure 7-38). The late summer maximum at Station 852 is consistent with a maximum at other stations. The model also shows a summer maximum, associated with algal excretion and with byproducts of predation. The computed maximum is in the observed range. The computed minimum, $\approx 2 \mathrm{~g} \mathrm{~m}^{-3}$, is less than observed, but the sparse observations preclude any conclusions about model behavior in this regard.

Near-bottom observed dissolved organic carbon is $\approx 3 \mathrm{~g} \mathrm{~m}^{-3}$ (Figure 7-39). Computed dissolved organic carbon is 1 to $2 \mathrm{~g} \mathrm{~m}^{-3}$ less than observed. The lower computed values are consistent with higher computed respiration, as will be seen in the next chapter. Cyclic behavior is apparent in the model near bottom. Highest concentrations occur in winter when dissolved organic carbon in runoff is mixed downward. Thereafter, dissolved organic carbon slowly decays until the subsequent turnover event.

Dissolved oxygen. Observed and computed dissolved oxygen levels at Station 852 show strong seasonal cycling at all depths. Near the surface, 
observed dissolved oxygen reaches 13 to $14 \mathrm{~g} \mathrm{~m}^{-3}$ in late spring (Figure 7-40). These concentrations are supersaturated, indicating production by the spring bloom (Figure 7-41). Dissolved oxygen declines but remains supersaturated through late summer when the annual minimum of 8 to $9 \mathrm{~g} \mathrm{~m}^{-3}$ is attained. Thereafter, dissolved oxygen increases, but remains subsaturated until the subsequent spring algal bloom. The model performs well in reproducing the observed concentrations as well as the cycling from supersaturated to subsaturated conditions (Figure 7-42).

At middepth, observed and computed dissolved oxygen levels are 1 to $2 \mathrm{~g} \mathrm{~m}^{-3}$ less than in surface waters (Figure 7-43). The decline from the spring maximum is smoother than in surface waters, indicative of respiratory activity rather than a sharp decline in algal oxygen production. The annual minimum, $\approx 7 \mathrm{~g} \mathrm{~m}^{-3}$, is short-lived; dissolved oxygen increases rapidly when the surfacemixed layer moves downward in autumn.

The largest annual range in dissolved oxygen occurs near the bottom (Figure 7-44). Computed and observed annual maximums greater than $11 \mathrm{~g} \mathrm{~m}^{-3}$ occur in spring, coincident with the algal bloom and prior to stratification. As the lake stratifies, dissolved oxygen declines to $\approx 4 \mathrm{~g} \mathrm{~m}^{-3}$ in late autumn, then recovers rapidly when the lake completely overturns in winter.

The most interesting feature of the vertical dissolved oxygen structure is the metalimnetic oxygen minimum that occurs from July through October or November (Figures 7-45 through 7-47). The processes that create the minimum are varied (Wetzel 1975). Two processes that have been assigned roles in the formation of the minimum are absent in this model: density-induced differential settling of particulate organic matter (Wetzel 1975) and copepod respiration (Shapiro 1960). The modeled minimum most likely occurs at the location where algal oxygen production is absent yet temperature is sufficient to produce high respiration of dissolved organic carbon. At lower depths, respiration is reduced by lower temperatures.

Fecal coliform. Observed fecal coliform levels in surface waters range up to $60 \mathrm{mpn}(100 \mathrm{ml})^{-1}$ (Figure 7-48). The preponderance of values, however, is less than $20 \mathrm{mpn}(100 \mathrm{ml})^{-1}$. Minimum observed values occur in the summer and early autumn, most likely because storm events are absent and temperatureinduced mortality is high. In late autumn and winter, fecal coliform concentrations are randomly distributed. The maximums are, no doubt, associated with loading events. The model demonstrates a seasonal behavior consistent with the observations although one-to-one correspondence with individual observations is absent. Lowest modeled concentrations occur in summer. As surface waters cool, mortality is reduced and concentrations increase until winter overturn. The overturn causes a dramatic decrease as surface waters are mixed downwards. Thereafter, computed concentrations increase erratically until warm summer temperatures and absence of runoff events create the summer minimum concentrations.

Modeled concentrations at this location are less than $20 \mathrm{mpn}(100 \mathrm{ml})^{-1}$, in agreement with the preponderance of the observations. The highest observed values are not represented in the model. The computations are affected by the 
crude loading information; e.g., all combined-sewer overflow events are characterized by a single concentration. Improved calculations of fecal coliform will require improved loading estimates.

\section{Statistics and scatterplots}

Statistical summaries of model results can provide insights not evident in graphical comparisons of observed and computed properties. Model statistics present problems, as well. No standard set of statistics exists. Neither are there standard criteria for acceptance of model results. In the absence of formal hypothesis testing, judgment must be employed in determining whether differences in statistics for various model runs, substances, or groupings are "significant" or not.

Comprehensive model statistics are presented in Table 7-2. Two very useful statistics are mean error (ME) and relative error (RE). Mean error indicates whether model results are higher or lower than observations, on average. Relative error is useful for comparisons between various substances or model applications to various systems. This discussion focuses on these statistics as applied to Lake Washington.

\begin{tabular}{|c|c|c|c|c|c|}
\hline \multicolumn{6}{|l|}{$\begin{array}{l}\text { Table 7-2 } \\
\text { Summary Statistics }\end{array}$} \\
\hline Station & Constituent & Relative Error & Mean Error & Correlation & Variance \\
\hline Station 852 & \multirow[t]{6}{*}{ Ammonium (mg/L) } & 0.002 & -0.00005 & 0.33 & 0.00008 \\
\hline Lake Washington Stations & & 0.026 & 0.0006 & 0.21 & 0.00013 \\
\hline Lake Union Stations & & 0.266 & 0.00855 & 0.17 & 0.00052 \\
\hline 826, 859, 890 (Apr-Oct) Level 1-6 & & 0.026 & -0.00061 & 0.25 & 0.00013 \\
\hline $826,859,890$ (Apr-Oct) Level 7-13 & & 0.019 & 0.00043 & 0.29 & 0.00012 \\
\hline $826,859,890$ (Apr-Oct) Level 14-41 & & 0.096 & 0.00195 & 0.18 & 0.00011 \\
\hline Station 852 & \multirow[t]{4}{*}{ Chlorophyll (ugm/L) } & 0.341 & 0.72 & 0.80 & 5.5 \\
\hline Lake Washington Stations & & 0.047 & 0.20 & 0.70 & 11.9 \\
\hline Lake Union Stations & & 0.123 & 0.59 & 0.58 & 15.5 \\
\hline 826, 859, 890 (Apr-Oct) Level 1-6 & & 0.136 & 0.65 & 0.80 & 10.4 \\
\hline Station 852 & \multirow[t]{6}{*}{ Dissolved Oxygen (mg/L) } & 0.038 & -0.34 & 0.88 & 0.91 \\
\hline Lake Washington Stations & & 0.049 & -0.46 & 0.85 & 1.06 \\
\hline Lake Union Stations & & 0.124 & -1.14 & 0.82 & 2.58 \\
\hline Surface $<10 \mathrm{~m}$ & & 0.059 & -0.54 & 0.88 & 0.79 \\
\hline Thermocline & & 0.074 & -0.66 & 0.88 & 0.76 \\
\hline Deep Water $>20 \mathrm{~m}$ & & 0.041 & -0.36 & 0.88 & 0.79 \\
\hline Station 852 & \multirow[t]{6}{*}{ Nitrate-Nitrite $(\mathrm{mg} / \mathrm{L})$} & 0.118 & 0.03006 & 0.87 & 0.00255 \\
\hline Lake Washington Stations & & 0.120 & 0.02238 & 0.88 & 0.00266 \\
\hline Lake Union Stations & & 0.212 & 0.02738 & 0.92 & 0.00153 \\
\hline 826, 859, 890 (Apr-Oct) Level 1-6 & & 0.131 & 0.02658 & 0.90 & 0.00206 \\
\hline $826,859,890$ (Apr-Oct) Level 7-13 & & 0.134 & 0.03164 & 0.86 & 0.00201 \\
\hline 826, 859, 890 (Apr-Oct) Level 14-41 & & 0.151 & 0.04287 & 0.65 & 0.00171 \\
\hline
\end{tabular}




\begin{tabular}{|c|c|c|c|c|c|}
\hline $\begin{array}{l}\text { Table 7-2 (Concluded) } \\
\text { Station }\end{array}$ & Constituent & Relative Error & Mean Error & Correlation & Variance \\
\hline Station 852 & \multirow[t]{6}{*}{ Ortho-Phosphate (mg/L) } & 0.306 & -0.00308 & 0.67 & 0.00004 \\
\hline Lake Washington Stations & & 0.197 & -0.00167 & 0.69 & 0.00003 \\
\hline Lake Union Stations & & 0.326 & 0.00246 & 0.33 & 0.00008 \\
\hline 826, 859, 890 (Apr-Oct) Level 1-6 & & 0.374 & -0.00311 & 0.66 & 0.00004 \\
\hline 826, 859, 890 (Apr-Oct) Level 7-13 & & 0.466 & -0.00452 & 0.62 & 0.00004 \\
\hline $826,859,890$ (Apr-Oct) Level 14-41 & & 0.331 & -0.00455 & 0.43 & 0.00005 \\
\hline Station 852 & \multirow[t]{6}{*}{ Temperature (Celcius) } & 0.071 & -0.80 & 0.97 & 1.23 \\
\hline Lake Washington Stations & & 0.089 & -1.09 & 0.96 & 1.70 \\
\hline Lake Union Stations & & 0.034 & -0.49 & 0.99 & 0.97 \\
\hline Surface $<10 \mathrm{~m}$ & & 0.094 & -1.13 & 0.96 & 1.63 \\
\hline Thermocline & & 0.111 & -1.22 & 0.93 & 1.73 \\
\hline Deep Water > 20m & & 0.116 & -0.94 & 0.93 & 0.64 \\
\hline Station 852 & \multirow[t]{6}{*}{ Total Nitrogen (mg/L) } & 0.097 & 0.03513 & 0.69 & 0.00339 \\
\hline Lake Washington Stations & & 0.071 & 0.02528 & 0.63 & 0.00705 \\
\hline Lake Union Stations & & 0.153 & 0.05272 & 0.68 & 0.00435 \\
\hline $826,859,890$ (Apr-Oct) Level 1-6 & & 0.061 & 0.02168 & 0.72 & 0.00391 \\
\hline 826, 859, 890 (Apr-Oct) Level 7-13 & & 0.077 & 0.02912 & 0.64 & 0.00318 \\
\hline 826, 859, 890 (Apr-Oct) Level 14-41 & & 0.101 & 0.04085 & 0.26 & 0.00303 \\
\hline Station 852 & \multirow[t]{6}{*}{ Total Phosphorus (mg/L) } & 0.044 & 0.00087 & 0.49 & 0.00012 \\
\hline Lake Washington Stations & & 0.164 & 0.00345 & 0.35 & 0.00018 \\
\hline Lake Union Stations & & 0.398 & 0.00842 & 0.28 & 0.0001 \\
\hline 826, 859, 890 (Apr-Oct) Level 1-6 & & 0.051 & 0.00097 & 0.40 & 0.00013 \\
\hline 826, 859, 890 (Apr-Oct) Level 7-13 & & 0.050 & -0.001 & 0.45 & 0.00012 \\
\hline $826,859,890$ (Apr-Oct) Level 14-41 & & 0.069 & -0.00161 & 0.41 & 0.00014 \\
\hline
\end{tabular}

Temperature. Overall, computed temperature exceeds observed by roughly $1{ }^{\circ} \mathrm{C}$. The excess is a little larger at the surface and in the thermocline than in deep water. The scatterplot (Figure 7-49) indicates the largest excess temperatures occur when observed temperatures exceed $10{ }^{\circ} \mathrm{C}$. Relative error in temperature computations is less than 9 percent.

Chlorophyll. Overall, observed chlorophyll exceeds computed by less than $0.2 \mathrm{mg} \mathrm{m}^{-3}$. Insufficient data exist to examine performance as a function of depth. The scatterplot (Figure 7-50) indicates that magnitude of computed error increases as a function of magnitude of observed chlorophyll. Similar behavior has been demonstrated in multiple alternate model applications. Relative error in chlorophyll computations is $\approx 5$ percent.

Nitrogen. Observed total nitrogen exceeds computed by $0.025 \mathrm{~g} \mathrm{~m}^{-3}$, on average. The computed shortfall in deep water is nearly double the shortfall at the surface. Computed nitrate is $0.022 \mathrm{~g} \mathrm{~m}^{-3}$ less than observed, on average, with larger discrepancies in the deep waters. Effectively, the entire deficit in total nitrogen is in the nitrate fraction. Observed ammonium exceeds computed by $0.0006 \mathrm{~g} \mathrm{~m}^{-3}$, on average. Consistent with the other components, mean error is greater in deep waters. Relative errors for total nitrogen, nitrate, and ammonium are 7 percent, 12 percent, and 3 percent, respectively. Scatterplots (Figures 7-51 
through 7-53) indicate that errors in total nitrogen and its components are homoscedastic. That is, the magnitude of the error does not increase in proportion to the magnitude of the observation.

Phosphorus. Observed total phosphorus exceeds computed by $0.0035 \mathrm{~g} \mathrm{~m}^{-3}$, on average. The analyses of mean error by depth indicates an opposing trend. Computed total phosphorus exceeds observed by up to $0.0016 \mathrm{~g} \mathrm{~m}^{-3}$ in deep waters. The analyses by depth were restricted to the April-October period. The opposing mean errors indicate that total phosphorus is undercomputed in winter but overcomputed in deep water during summer. Relative error, for all observations, is 16 percent. The scatterplot (Figure 7-54) indicates errors are largely homoscedastic, although the magnitude of some extreme observations is not attained by the model at all.

Computed ortho-phosphorus exceeds observed, on average by $0.0017 \mathrm{~g} \mathrm{~m}^{-3}$. A small tendency exists for errors to be larger in the thermocline and deep water, and in summer rather than winter. These properties reflect the trapping of orthophosphorus at middepth during summer stratification. Relative error is nearly 20 percent. The scatterplot (Figure 7-55) indicates no apparent relationship between error and magnitude of observations.

Dissolved oxygen. Computed dissolved oxygen exceeds observed by less than $0.5 \mathrm{~g} \mathrm{~m}^{-3}$, on average. Largest discrepancies appear to be in the thermocline region although it is difficult to discern if this apparent property is significant. No apparent relationship exists between error and concentration (Figure 7-56). Relative error is 5 percent.

\section{Comparison with other systems}

Relative error was compared for a few key parameters with relative error in two recent model applications, Chesapeake Bay (Cerco and Noel in preparation) and the lower St. Johns River, Florida (Tillman et al. in preparation). Chesapeake Bay is a partially mixed estuary located in the mid-Atlantic region. The lower St. Johns is a partially to well-mixed estuary located in northeast Florida. Relative error for Lake Washington (Figure 7-57) is much less than for the estuarine applications. The estuaries demonstrate highest relative error for chlorophyll while Lake Washington demonstrates highest relative error for phosphorus.

The lower error for Lake Washington is suspected to reflect the properties of a lake relative to an estuary. The lake is a basin. Material introduced to the lake must either settle or flow out over the dam. An estuary is open at the lower end. Tides move material upstream and downstream twice a day. Net transport across the open boundary is especially difficult to quantify.

Computation of phosphorus in the estuaries, especially Chesapeake Bay, has been found to be equally vexing as in Lake Washington. The nature of the problem is the same. Without bacterial uptake, dissolved phosphate accumulates to excess levels. In the estuaries, however, chlorophyll relative error exceeds phosphorus relative error. The reason for the lower chlorophyll error in Lake 
Washington is not apparent. Both estuaries experience spring algal blooms as does Lake Washington. Consequently, similar relative errors would be expected.

The dissolved oxygen relative error requires some explanation. Chesapeake Bay experiences bottom-water anoxia during summer months. Since prediction of this anoxia is critical, the statistical computation is restricted to summer, bottom dissolved oxygen. Statistics for the St. Johns and Lake Washington include all observations. These tend to be improved, relative to Chesapeake Bay, since they include surface and cold-weather samples in which oxygen tends to equilibrate with the atmosphere. Computation of dissolved oxygen under these circumstances is largely a function of the algorithm used to compute saturation dissolved oxygen concentration. Also, the denominator in the relative error computation, essentially saturation concentration, is larger than the mean bottom dissolved oxygen that forms the denominator in the Chesapeake Bay statistics. Still, relative dissolved oxygen error is lower in Lake Washington than in the St. Johns, for which the statistic includes the entire population of dissolved oxygen observations.

Virtually all CE-QUAL-ICM applications to date have been to estuaries and coastal lagoons. Lake Washington is the first lake. While it cannot be generalized that lake applications have lower errors than estuarine applications, this study compares favorably with the best alternate applications.

\section{References}

Cerco, C., and Noel, M. "The 2002 Chesapeake Bay eutrophication model" (in preparation), U.S. Army Engineer Research and Development Center, Vicksburg, MS.

DiToro, D., and Matysik, W. (1979). "Phosphorus recycle and chlorophyll in the Great Lakes," Journal of Great Lakes Research 5(3-4), 233-245.

Koenings, J., and Edmundson, J. (1991). "Secchi disk and photometer estimates of light regimes in Alaska lakes: Effects of yellow color and turbidity," Limnology and Oceanography 36(1), 91-105.

Pennock, J. (1985). "Chlorophyll distributions in the Delaware Estuary: Regulation by light-limitation," Estuarine, Coastal and Shelf Science 21, 711-725.

Shapiro, J. (1960). "The cause of a metalimnetic minimum of dissolved oxygen," Limnology and Oceanography 5, 216-227.

Thingstad, T., Skjodal, E., and Bohne, R. (1993). "Phosphorus cycling and algalbacterial competition in Sandsfjord, western Norway," Marine Ecology Progress Series 99, 239-259.

Tillman, D., Cerco, C., Noel, M., Martin, J., and Hamrick, J. “Three-dimensional eutrophication model of the lower St. Johns River, Florida" (in preparation), U.S. Army Engineer Research and Development Center, Vicksburg MS. 
Walker, T. (1982). "The use of a Secchi disk to measure attenuation of underwater light for photosynthesis," Journal of Applied Ecology 19, 539544.

Wetzel, R. (1975). "The oxygen content of fresh waters." Limnology. W. B. Saunders, Philadelphia.

Zweifel, U., Norrman, B., and Hagstrom, A. (1993). "Consumption of dissolved organic carbon by marine bacteria and demand for inorganic nutrients," Marine Ecology Progress Series 101, 23-32.

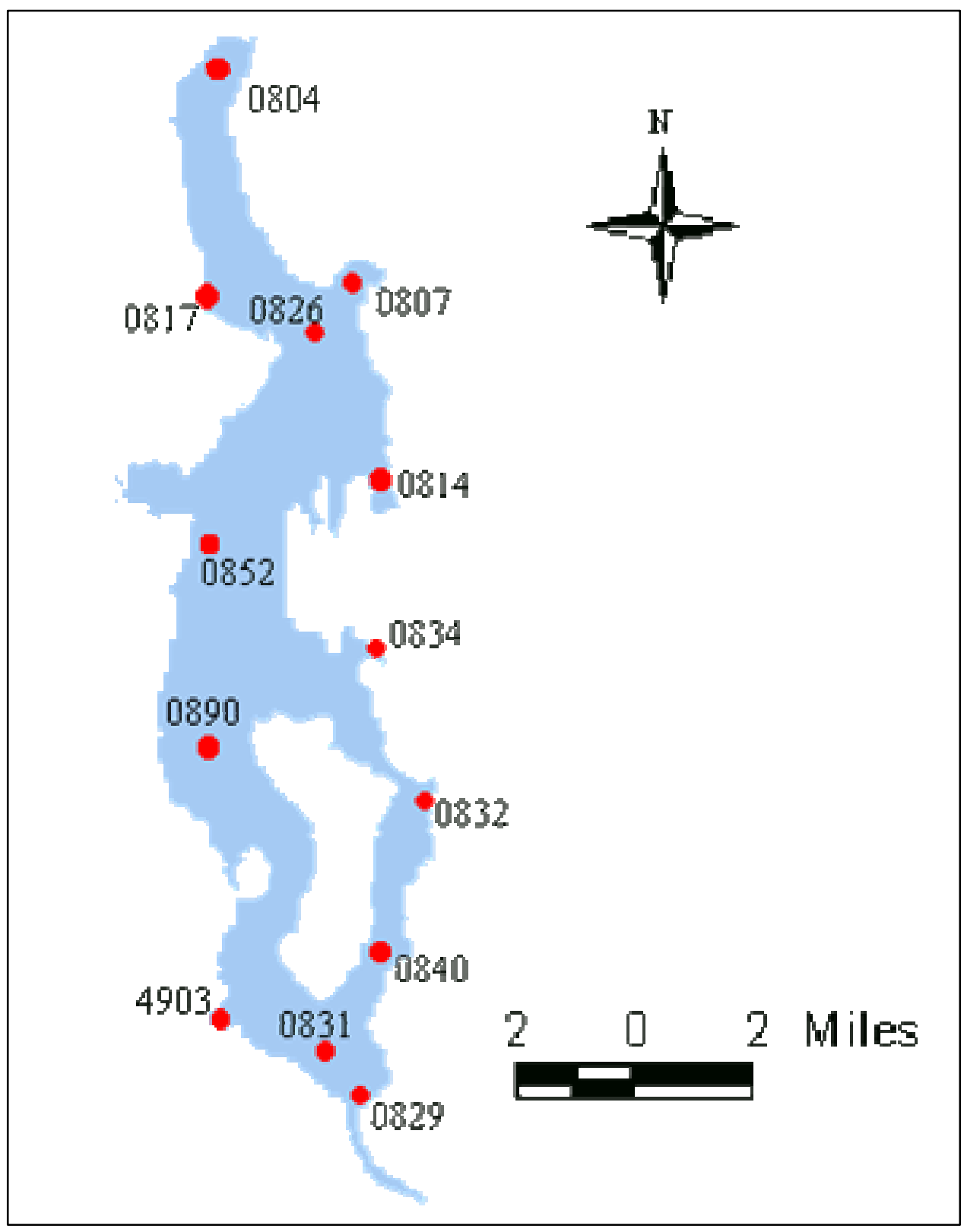

Figure 7-1. Lake Washington sample stations 


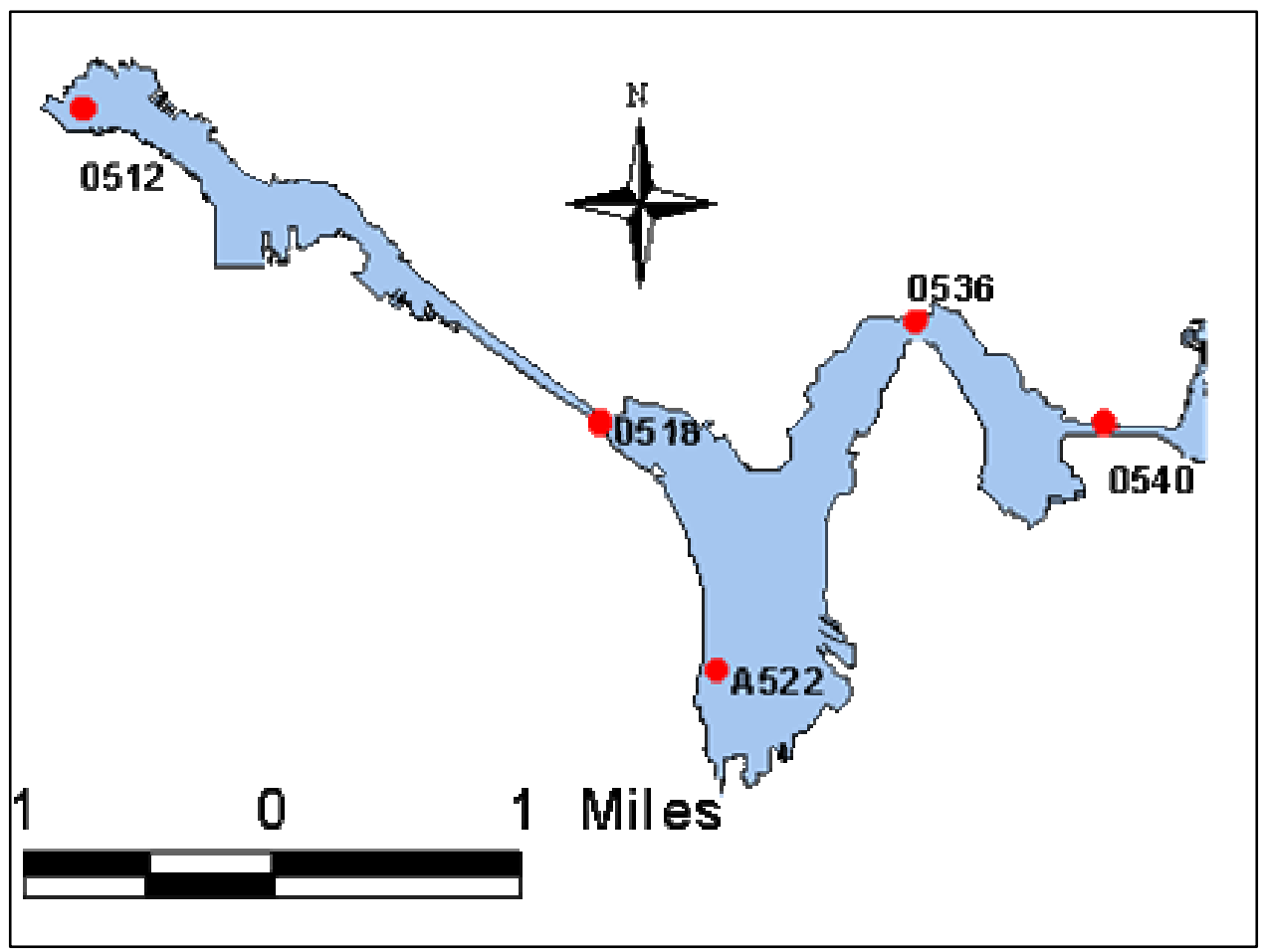

Figure 7-2. Lake Union sample stations

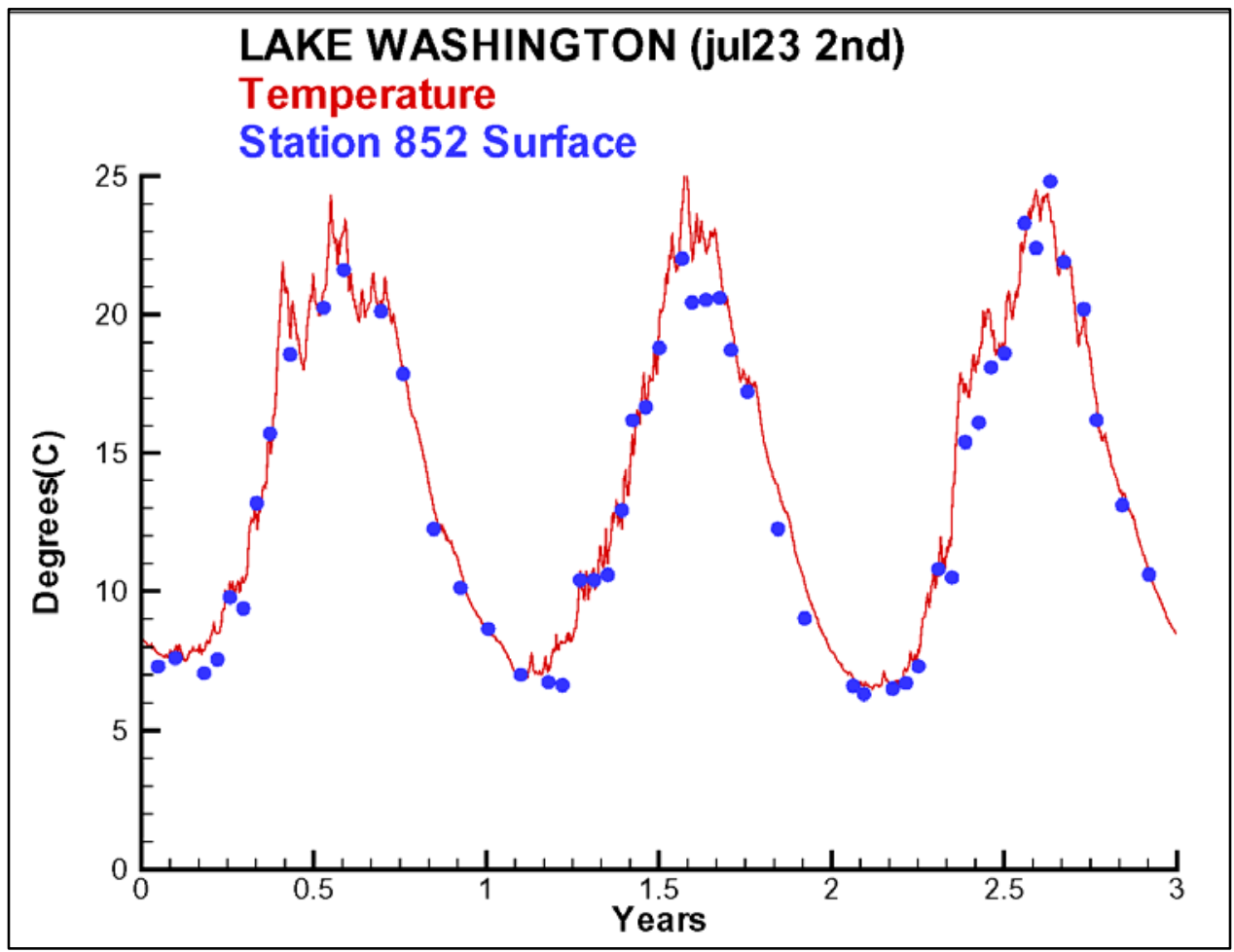

Figure 7-3. Observed and computed surface temperatures at Station 852 


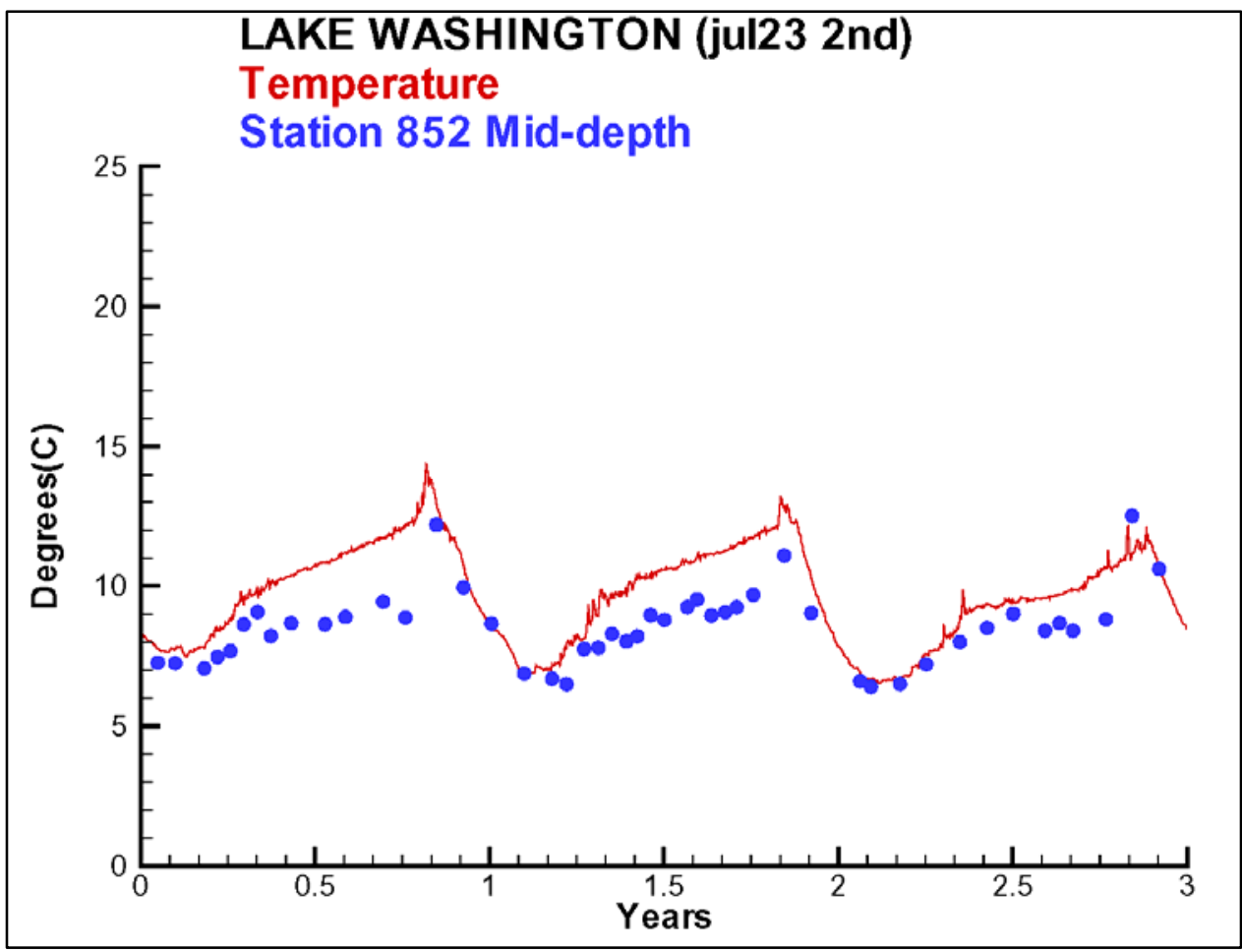

Figure 7-4. Observed and computed middepth temperatures at Station 852

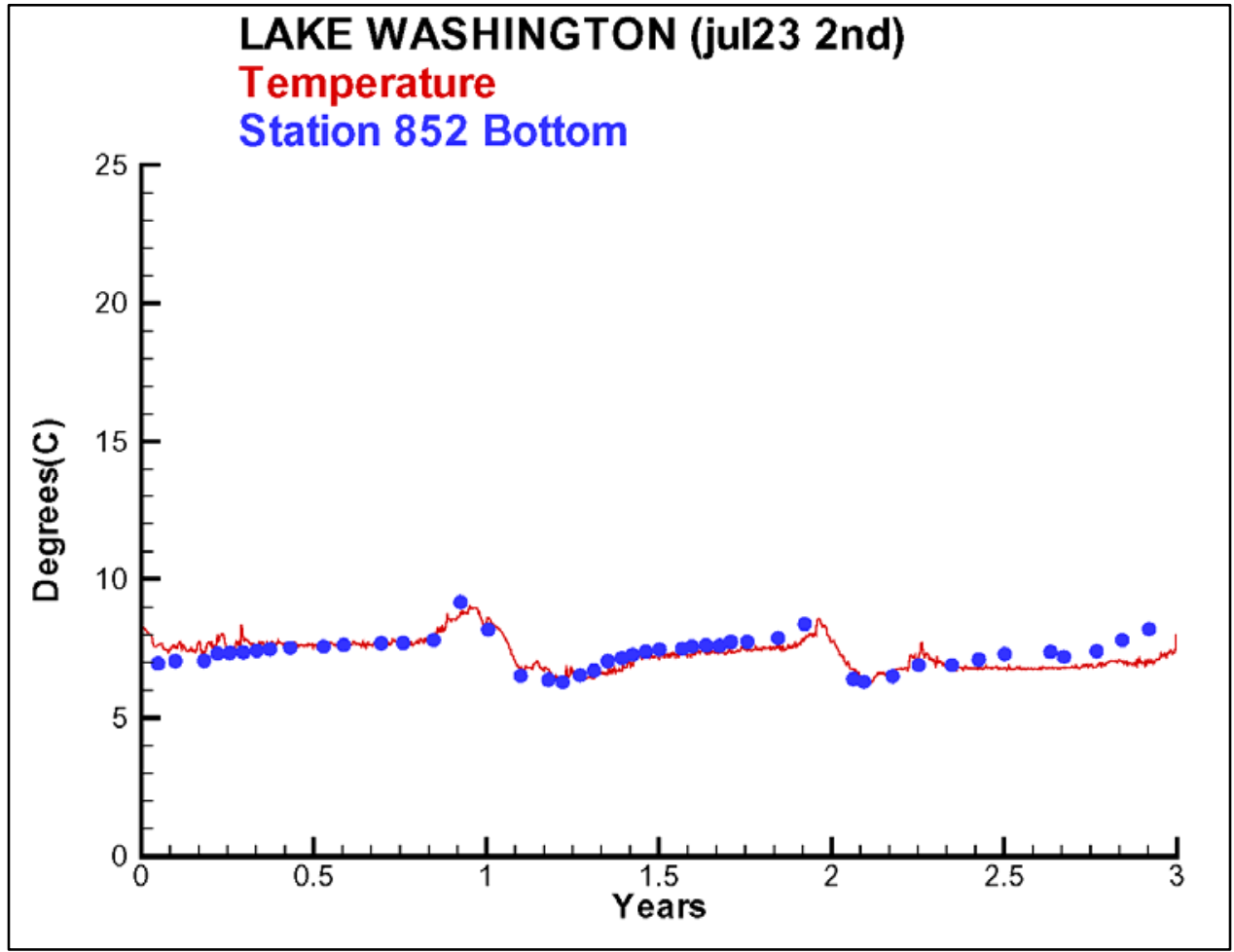

Figure 7-5. Observed and computed bottom temperatures at Station 852 


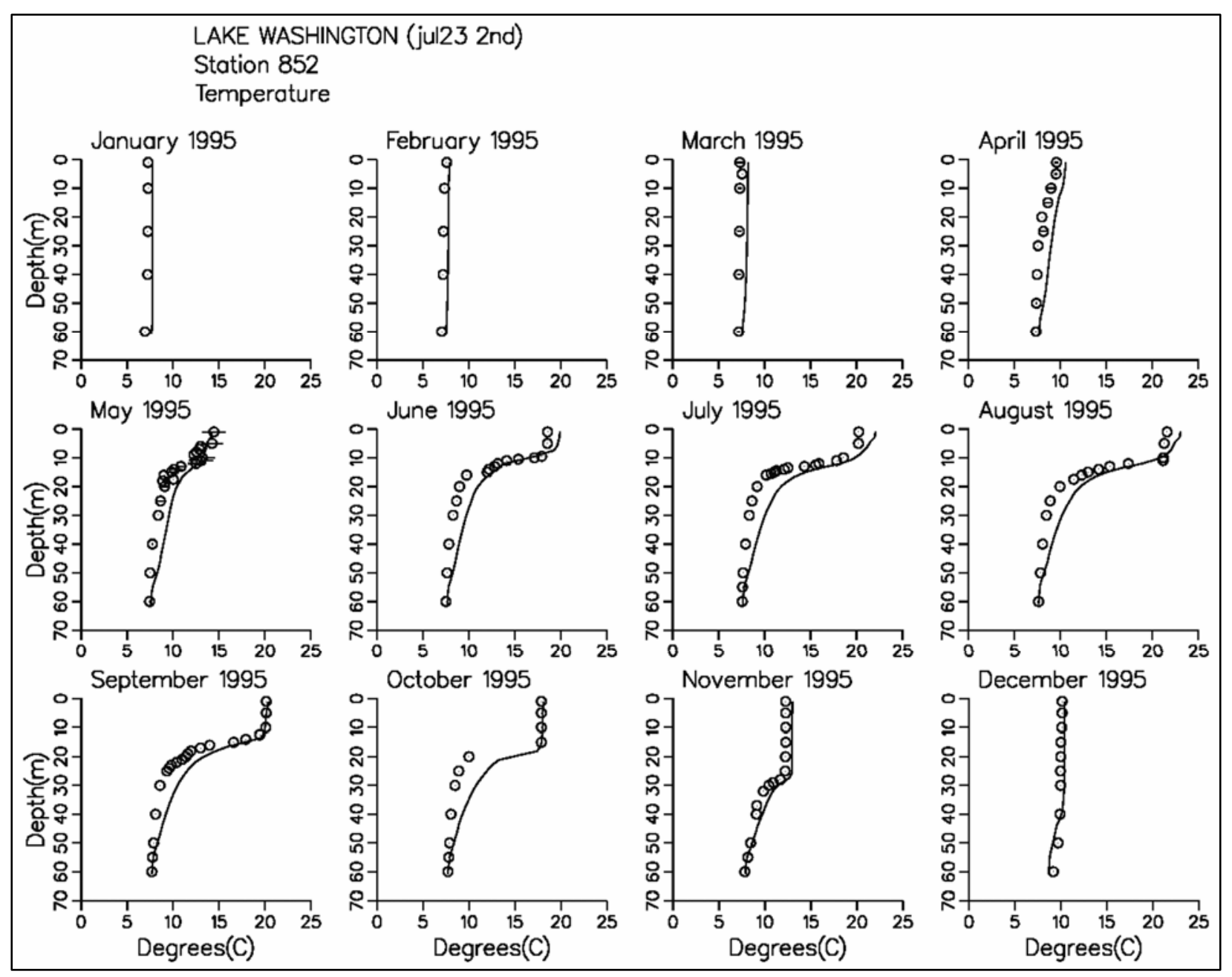

Figure 7-6. Observed and computed temperature profiles at Station 852 for 1995 


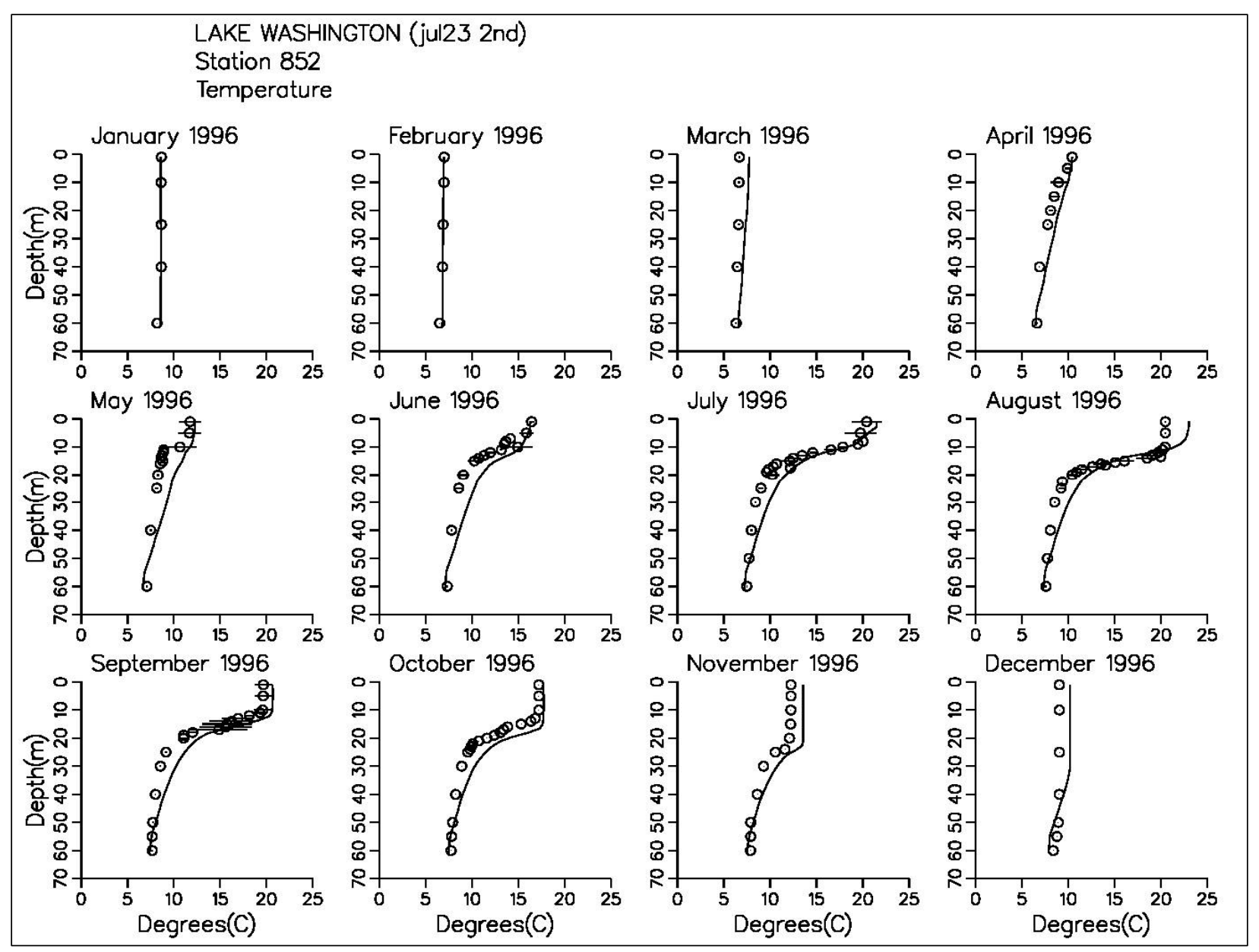

Figure 7-7. Observed and computed temperature profiles at Station 852 for 1996 


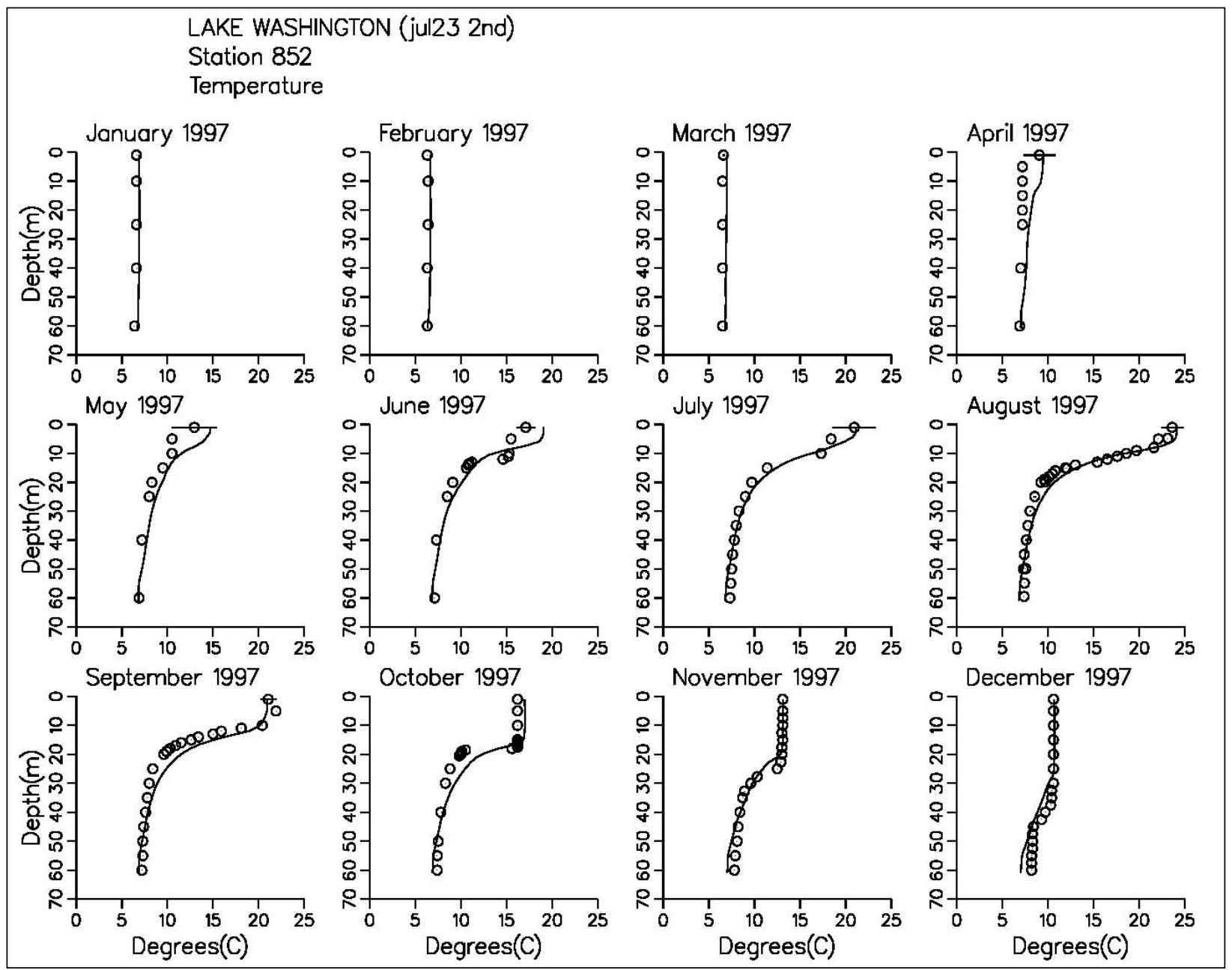

Figure 7-8. Observed and computed temperature profiles at Station 852 for 1997 


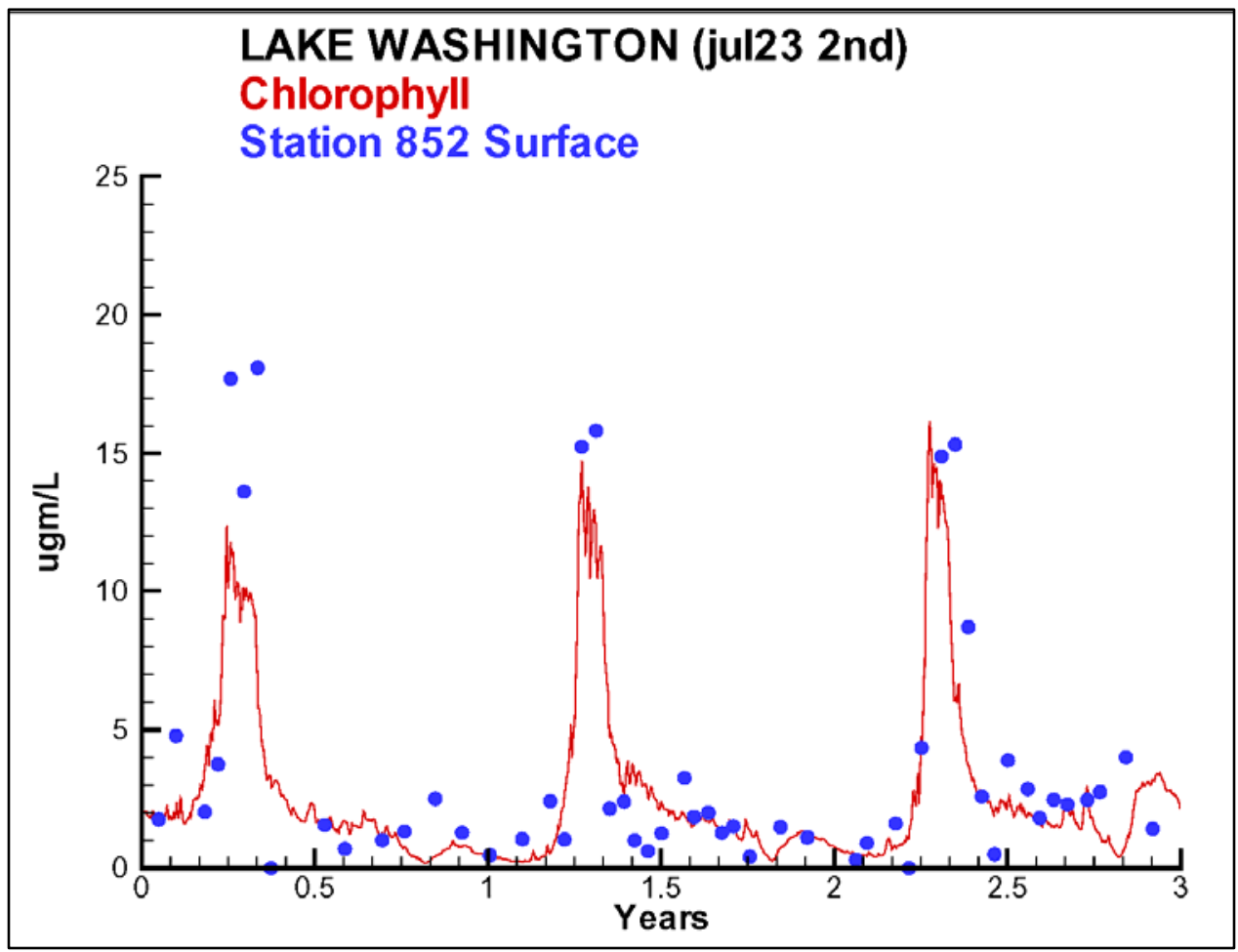

Figure 7-9. Observed and computed surface chlorophyll at Station 852

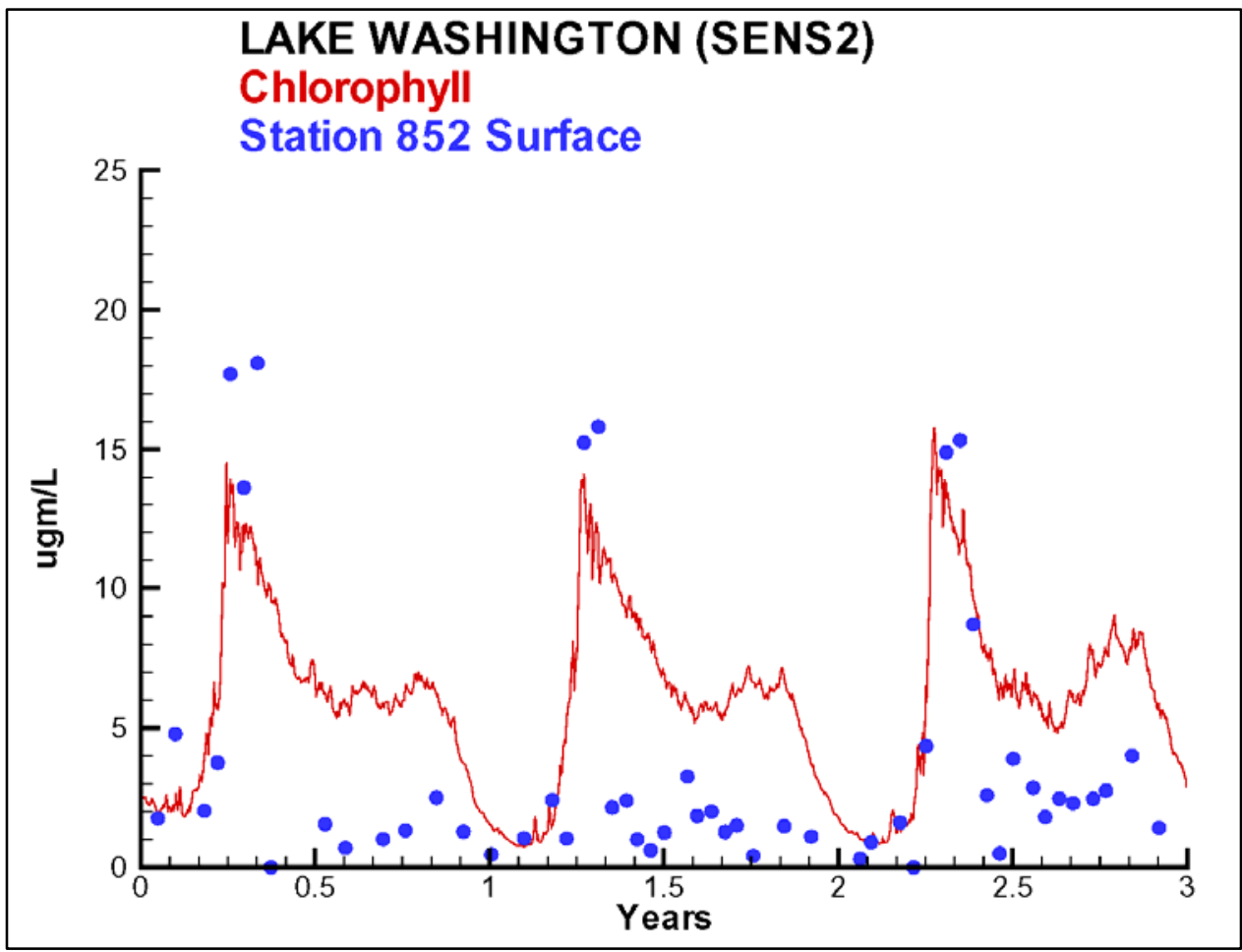

Figure 7-10. Chlorophyll computed with low, constant predation rate compared to observations at Station 852 


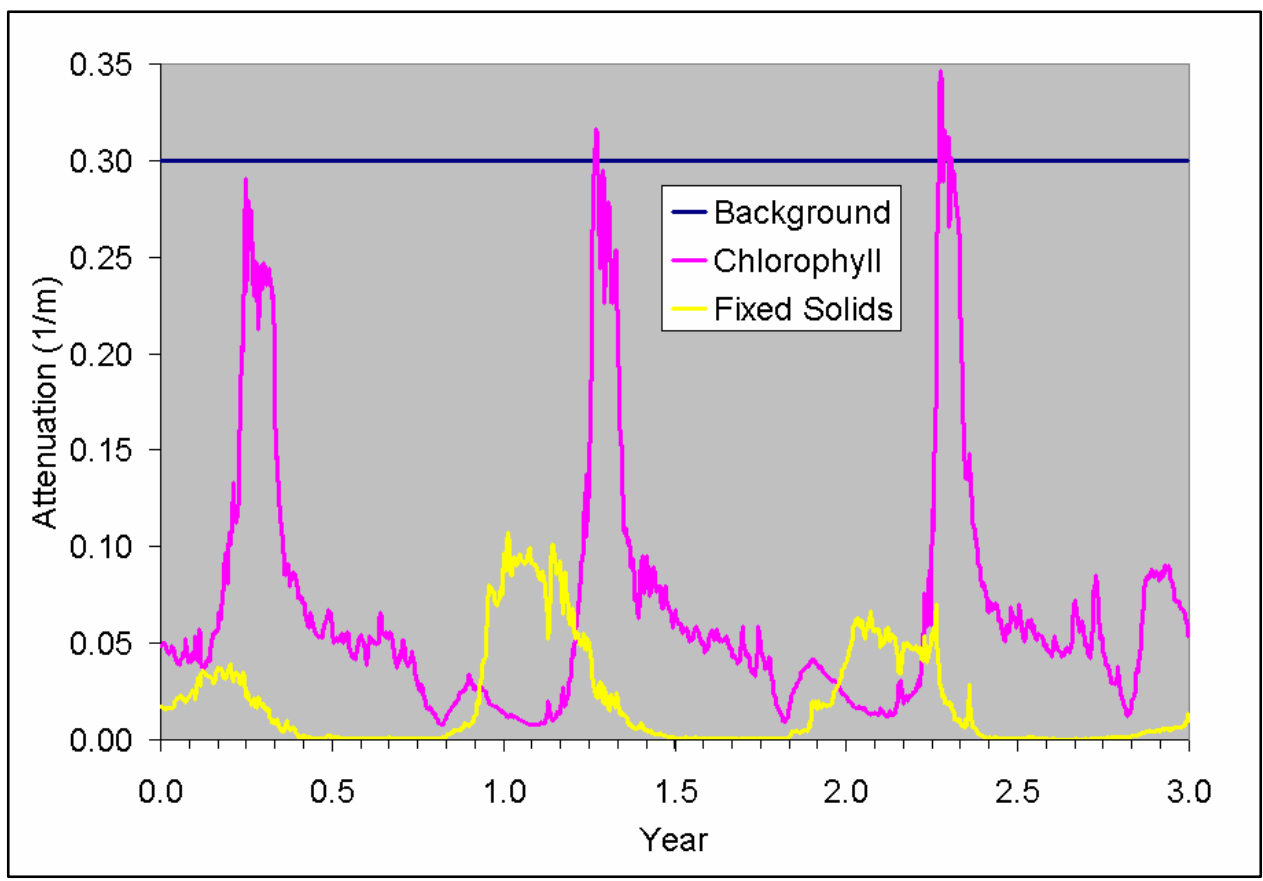

Figure 7-11. Computed components of light attenuation at Station 852

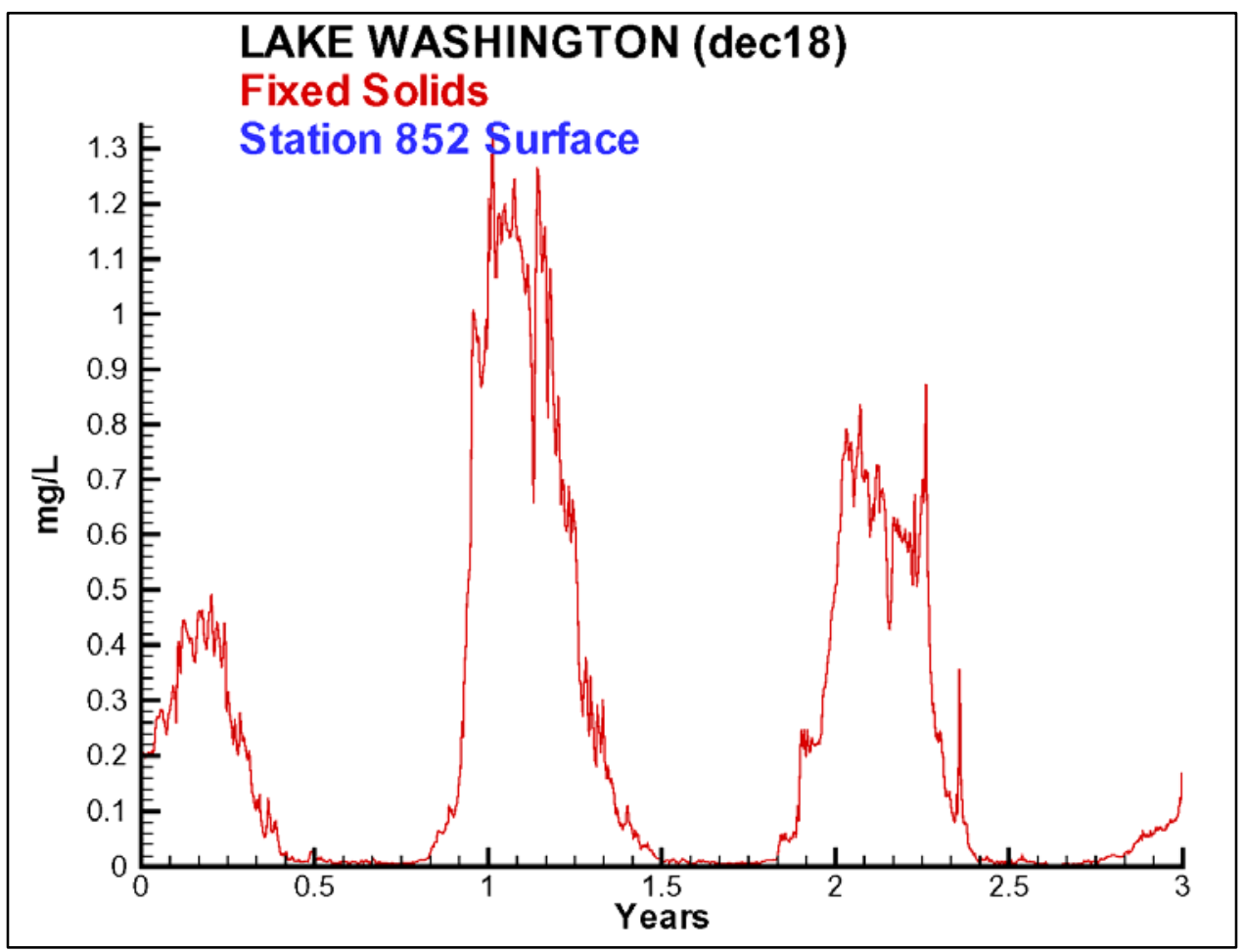

Figure 7-12. Computed surface fixed solids at Station 852 


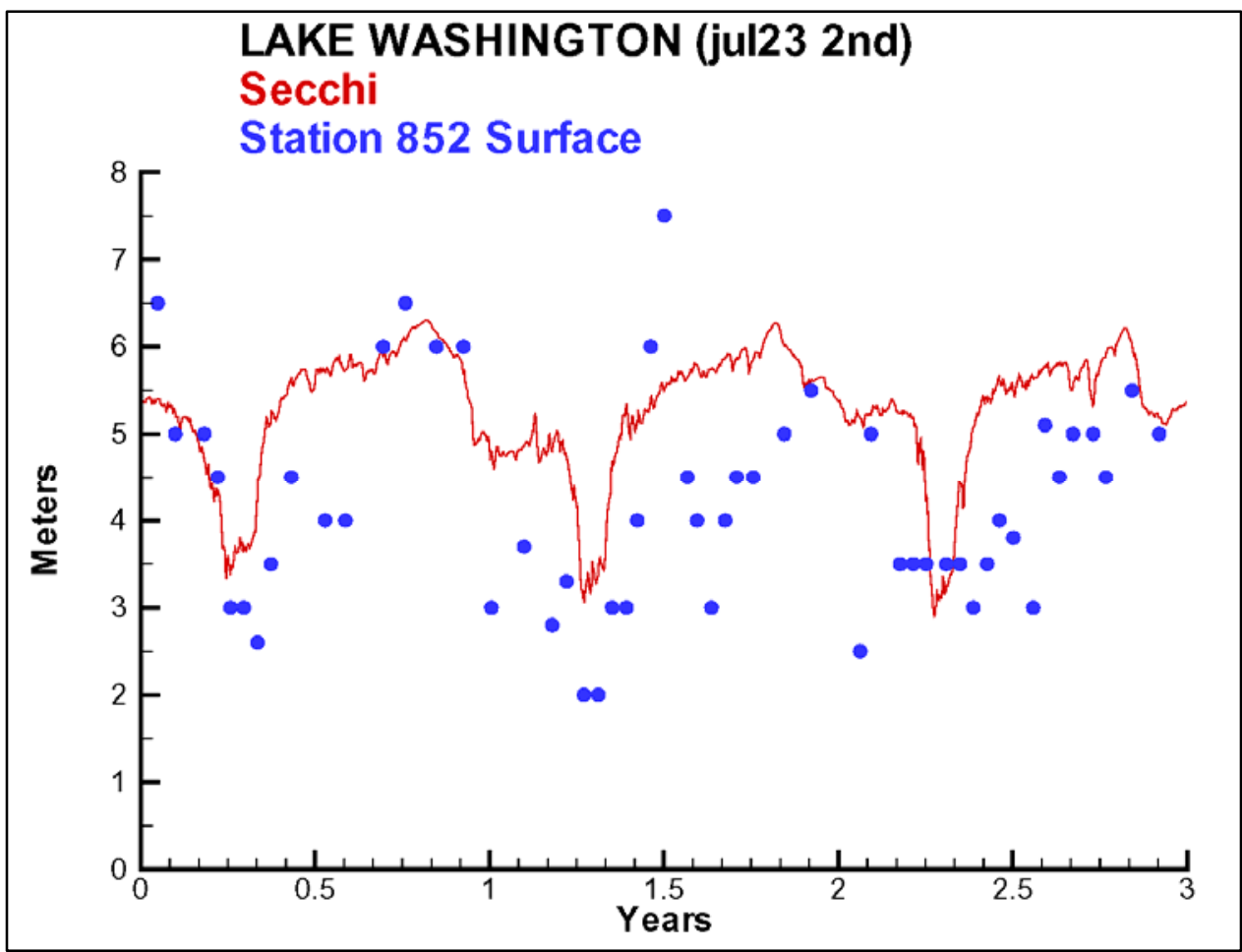

Figure 7-13. Observed and computed Secchi depth at Station 852

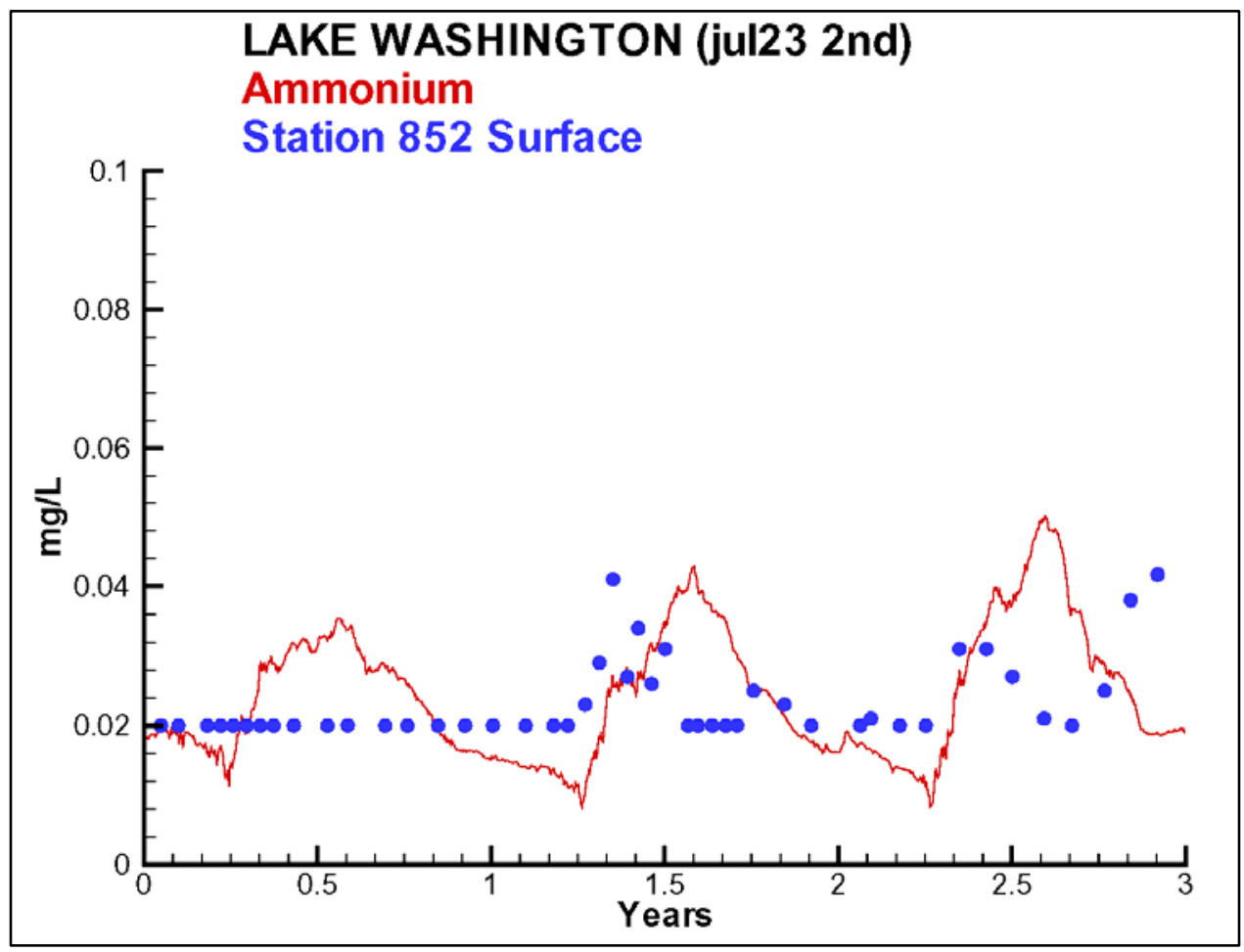

Figure 7-14. Observed and computed surface ammonium at Station 852 


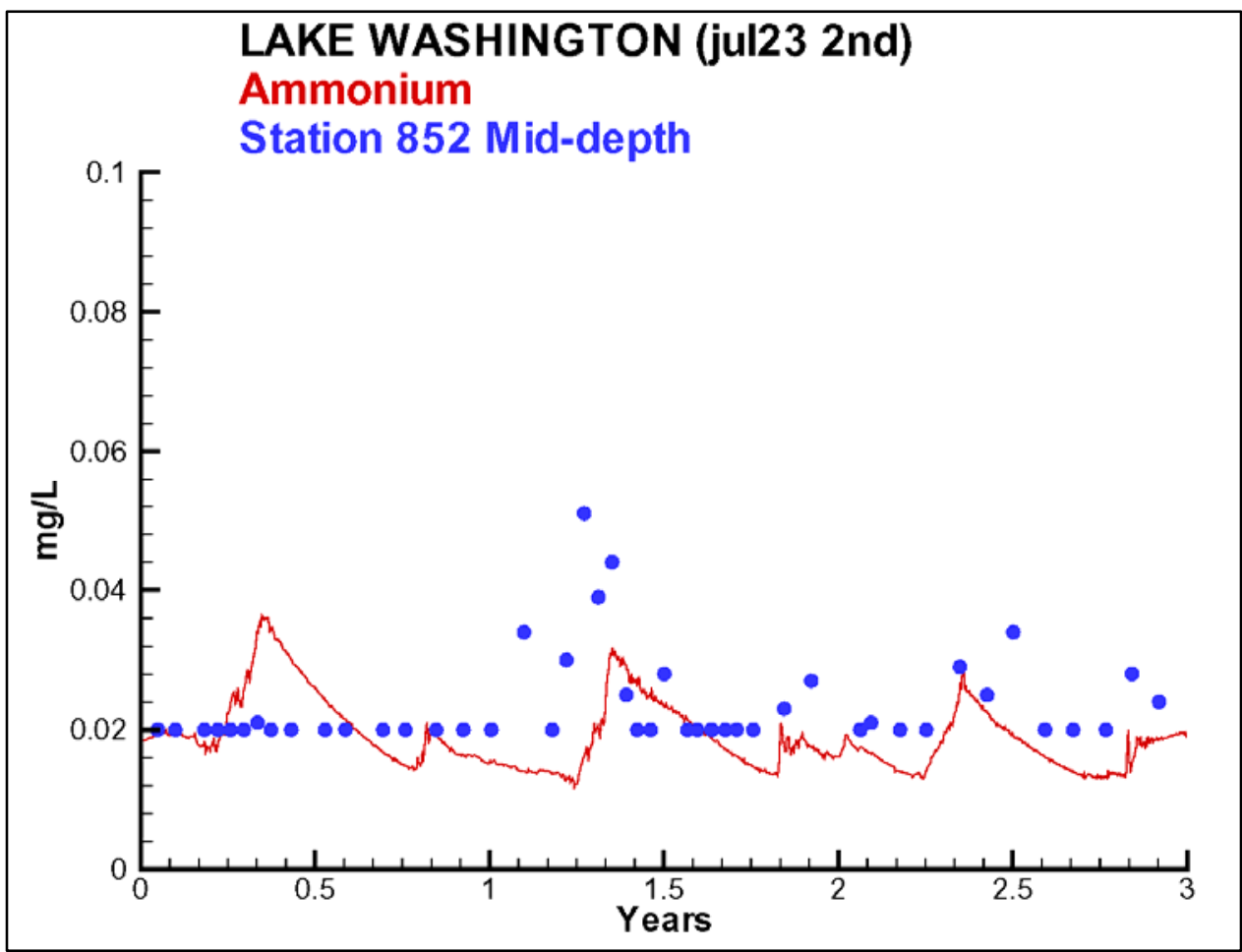

Figure 7-15. Observed and computed middepth ammonium at Station 852

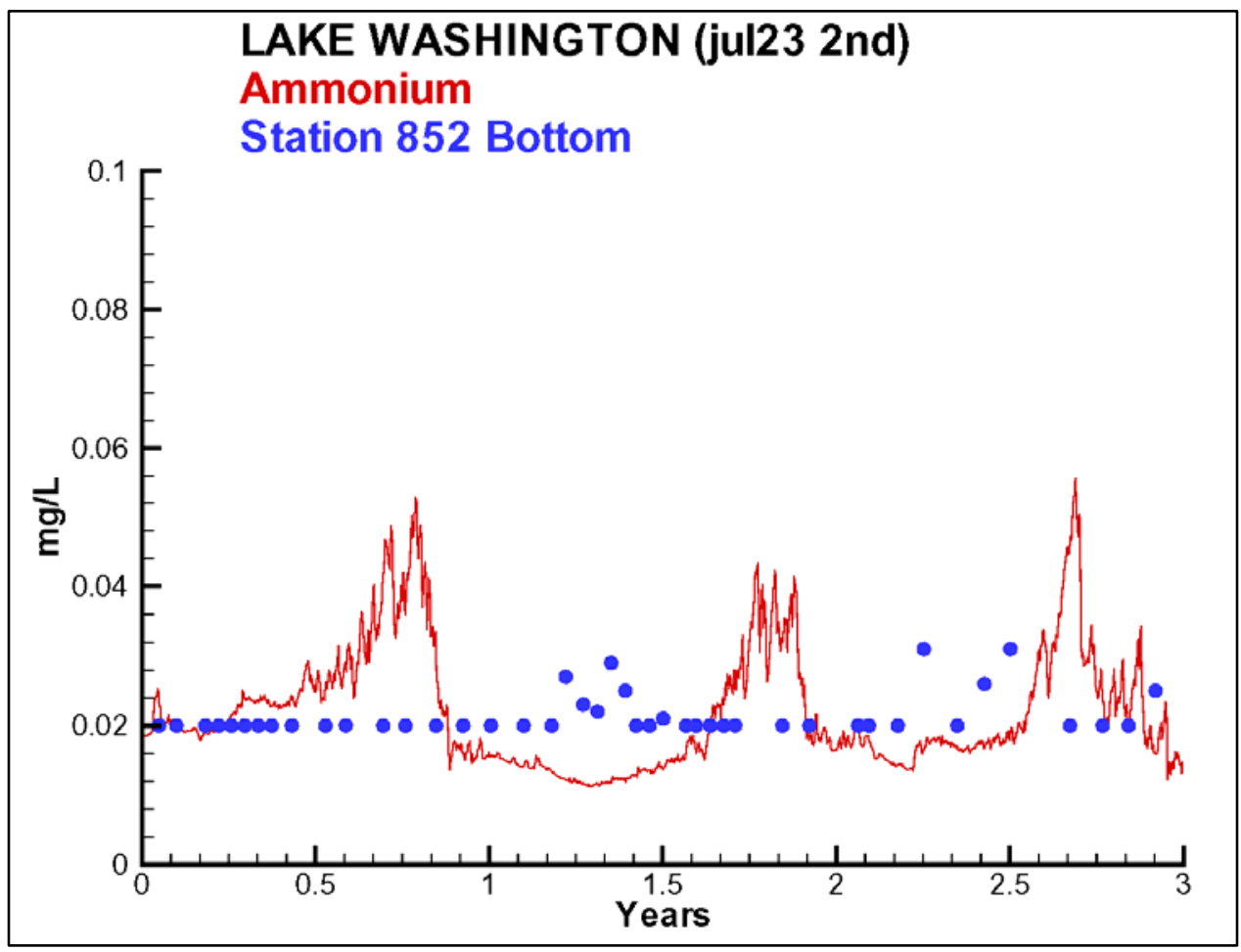

Figure 7-16. Observed and computed bottom ammonium at Station 852 


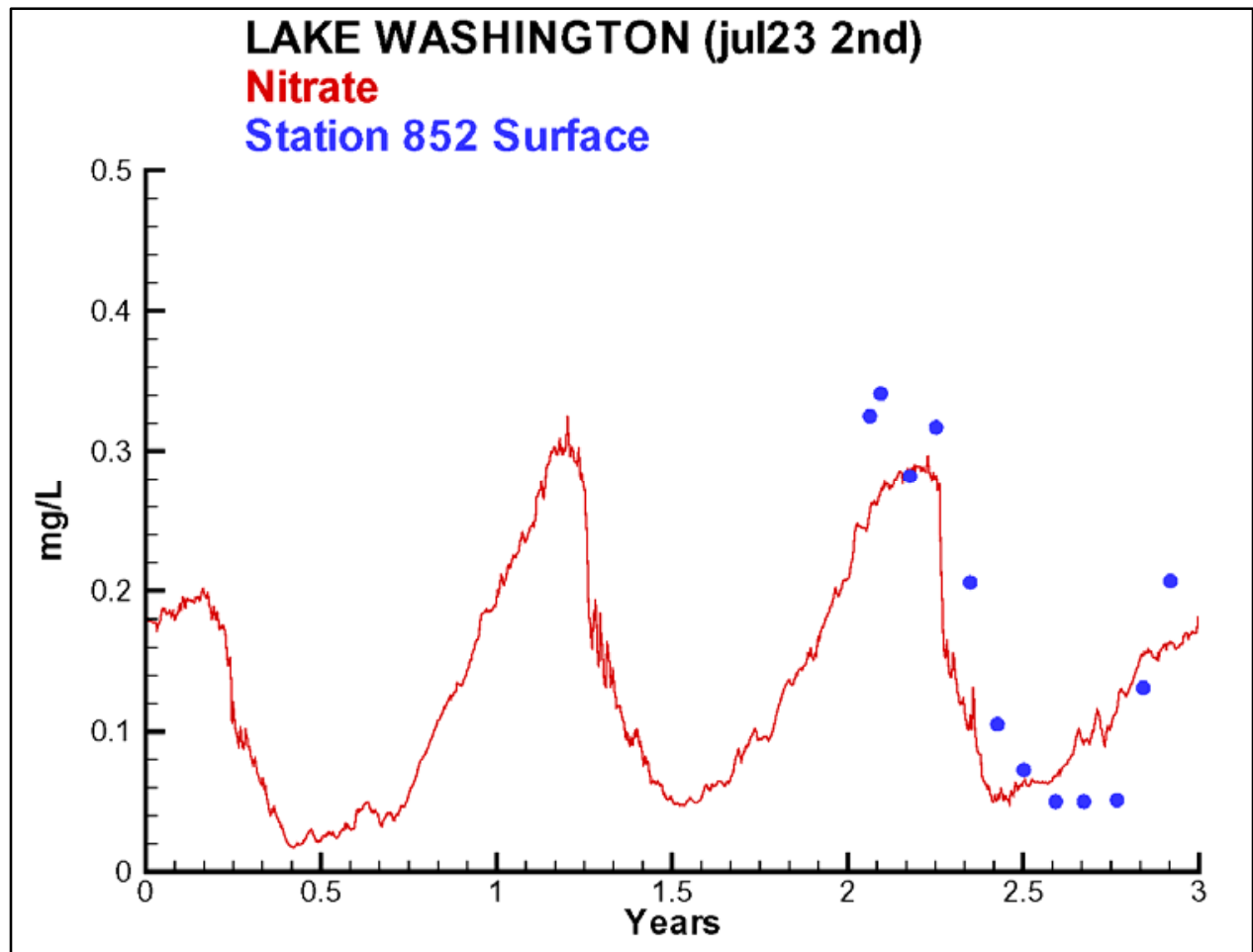

Figure 7-17. Observed and computed surface nitrate at Station 852 


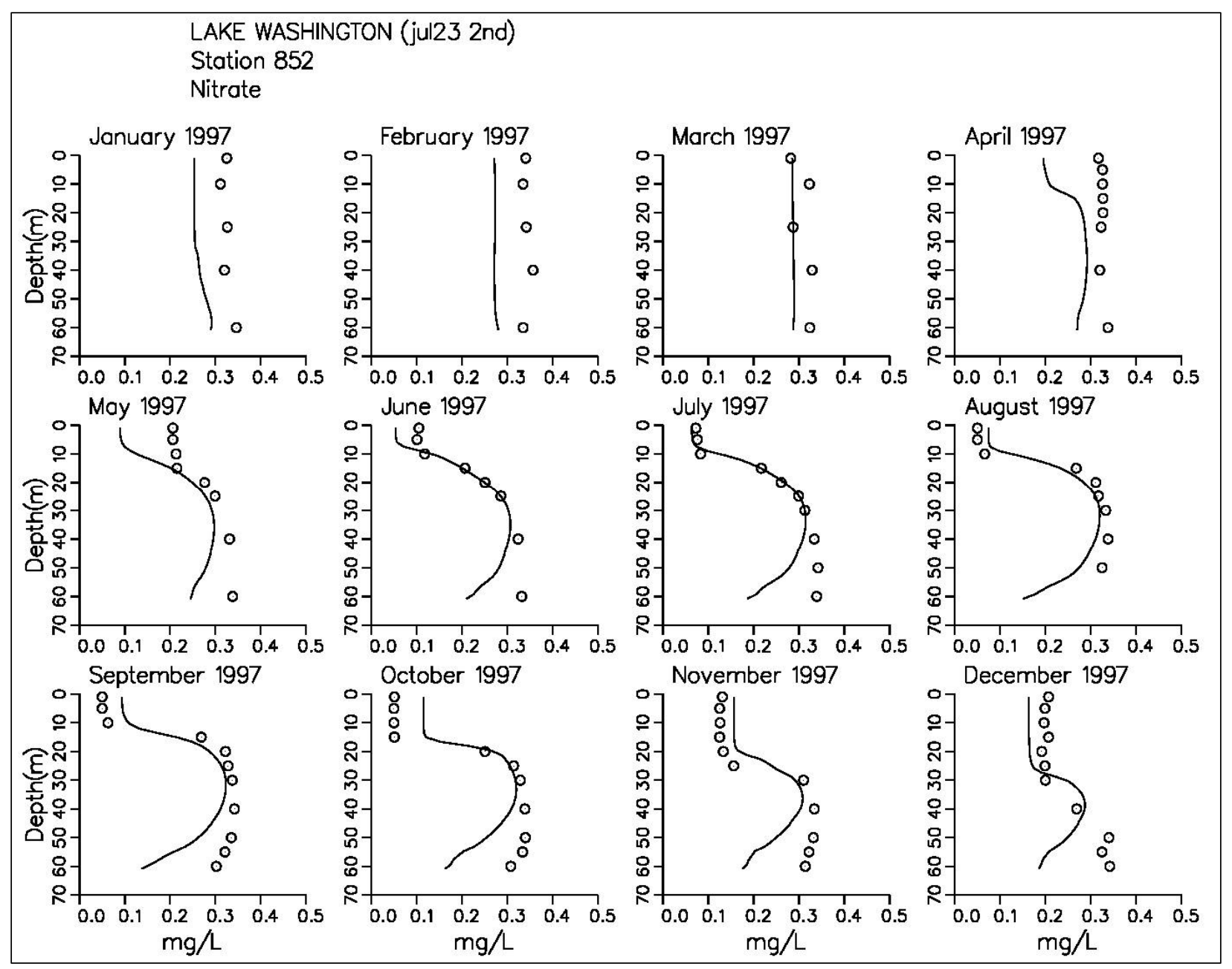

Figure 7-18. Observed and computed nitrate profiles at Station 852 for 1997 


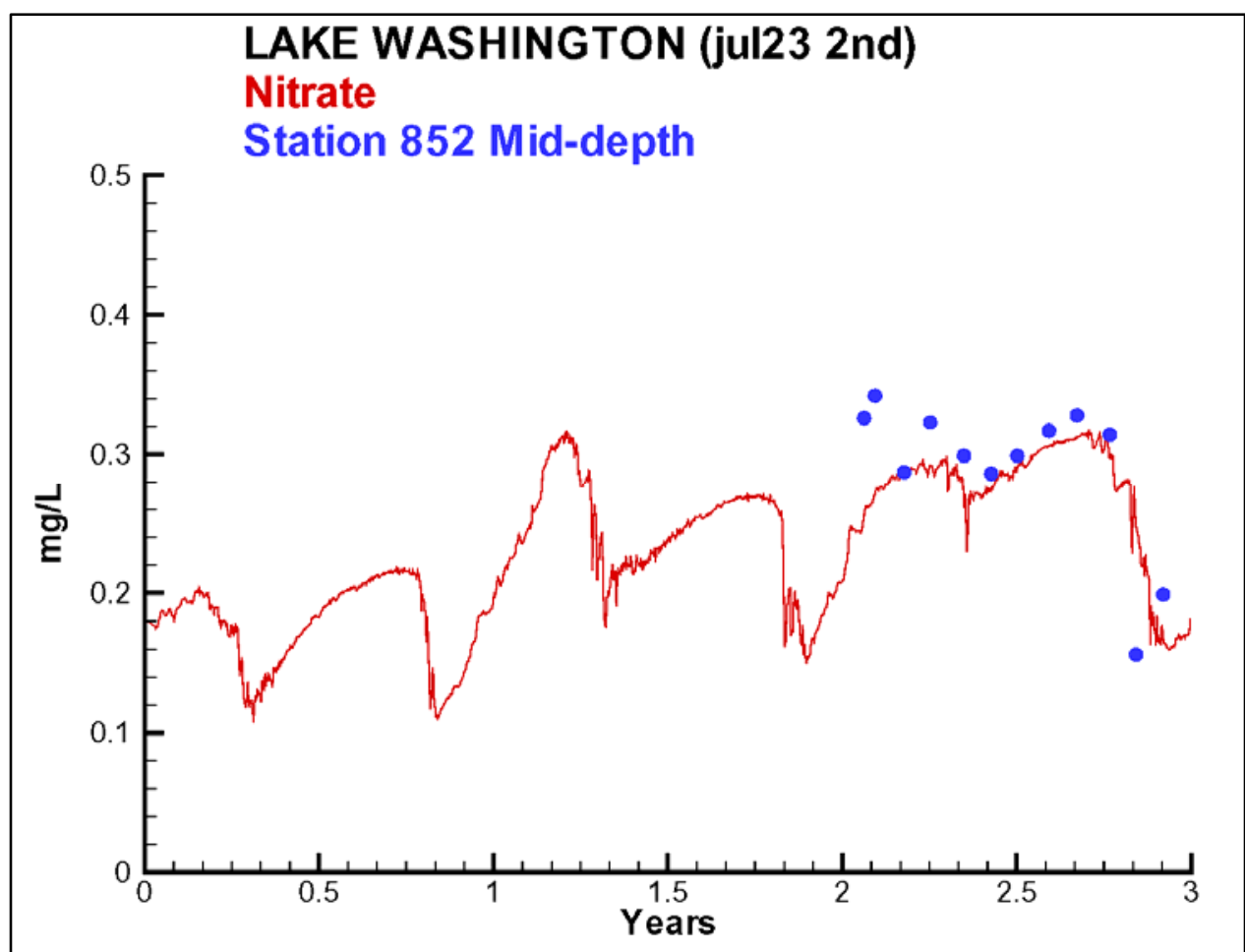

Figure 7-19. Observed and computed middepth nitrate at Station 852

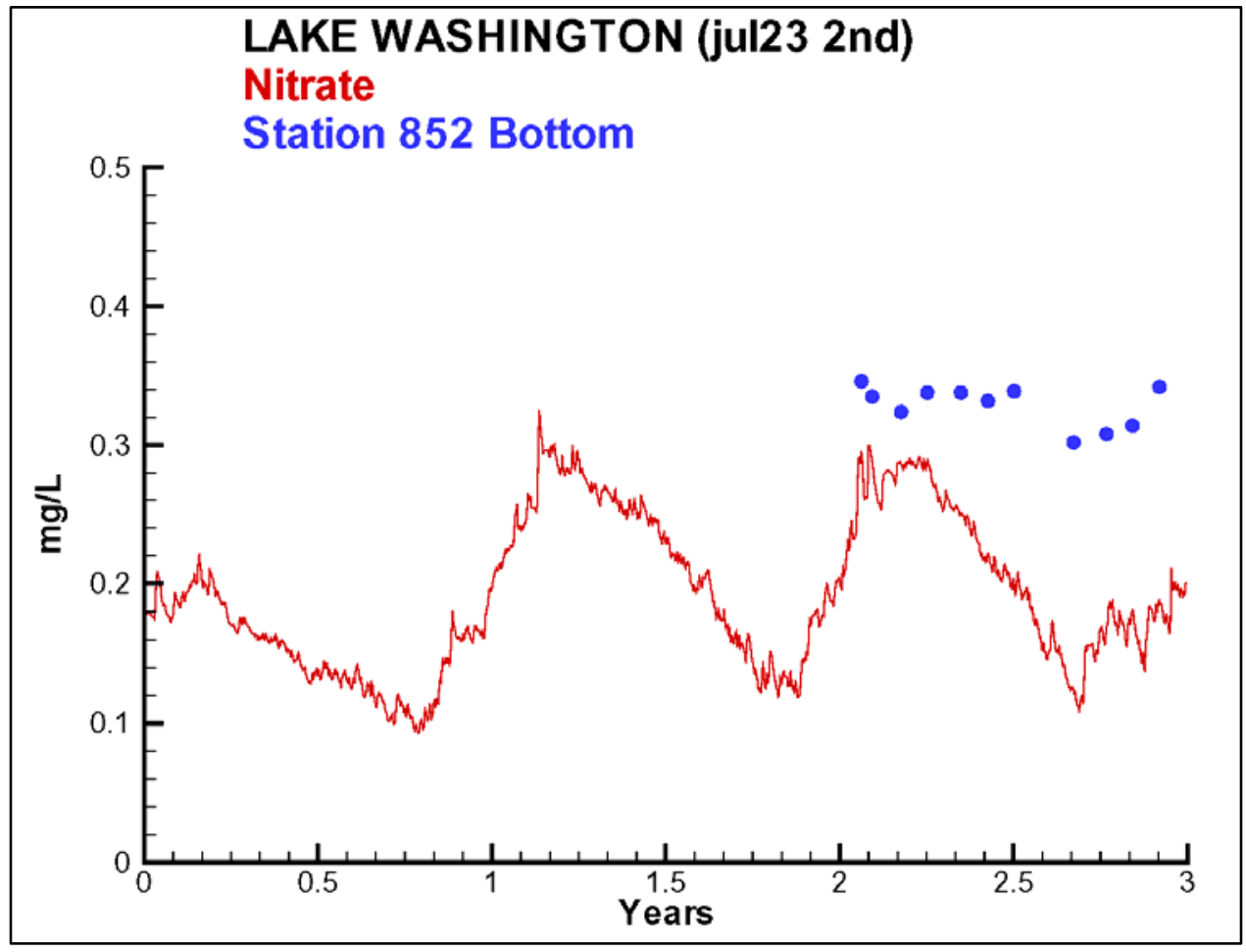

Figure 7-20. Observed and computed bottom nitrate at Station 852 


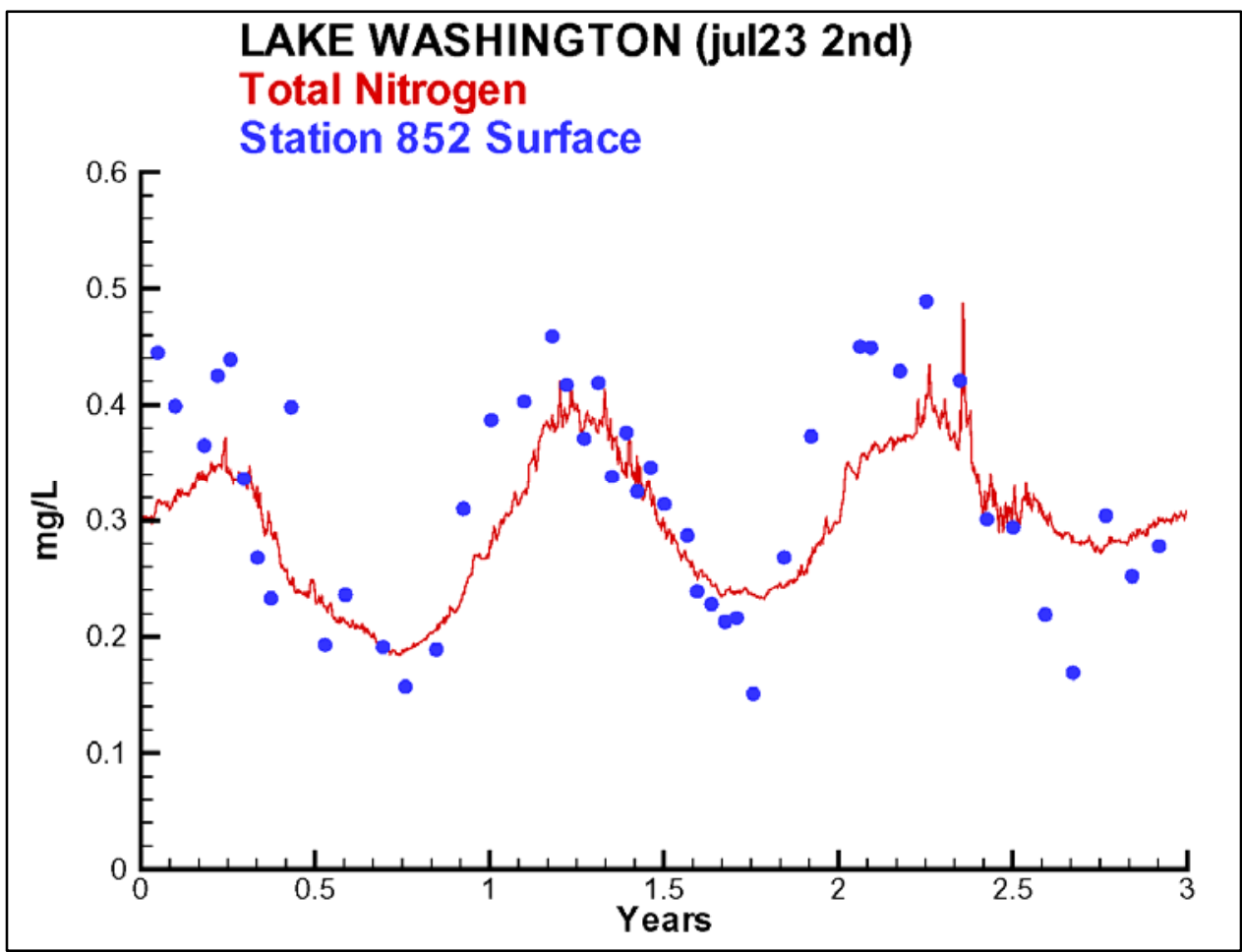

Figure 7-21. Observed and computed surface total nitrogen at Station 852

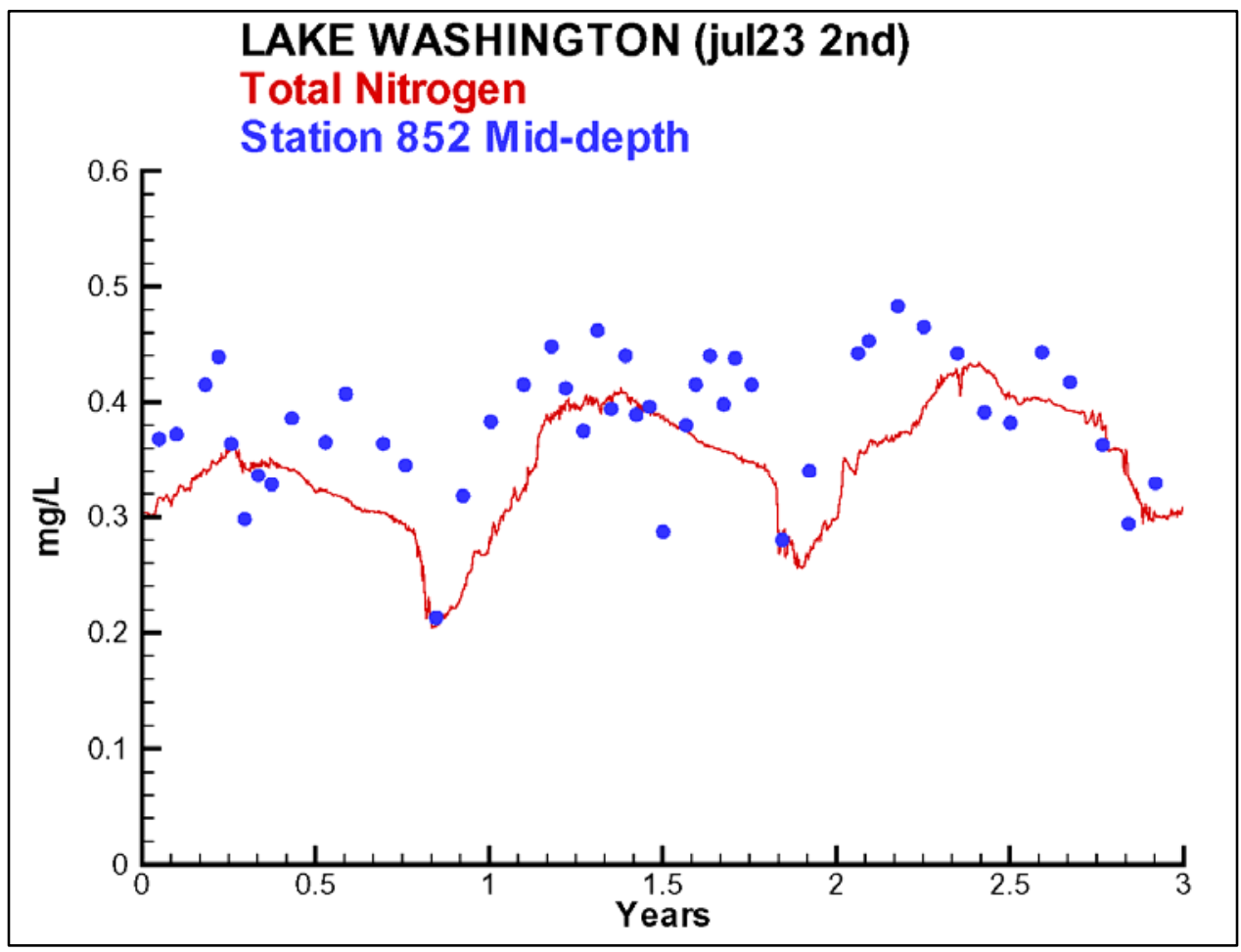

Figure 7-22. Observed and computed middepth total nitrogen at Station 852 


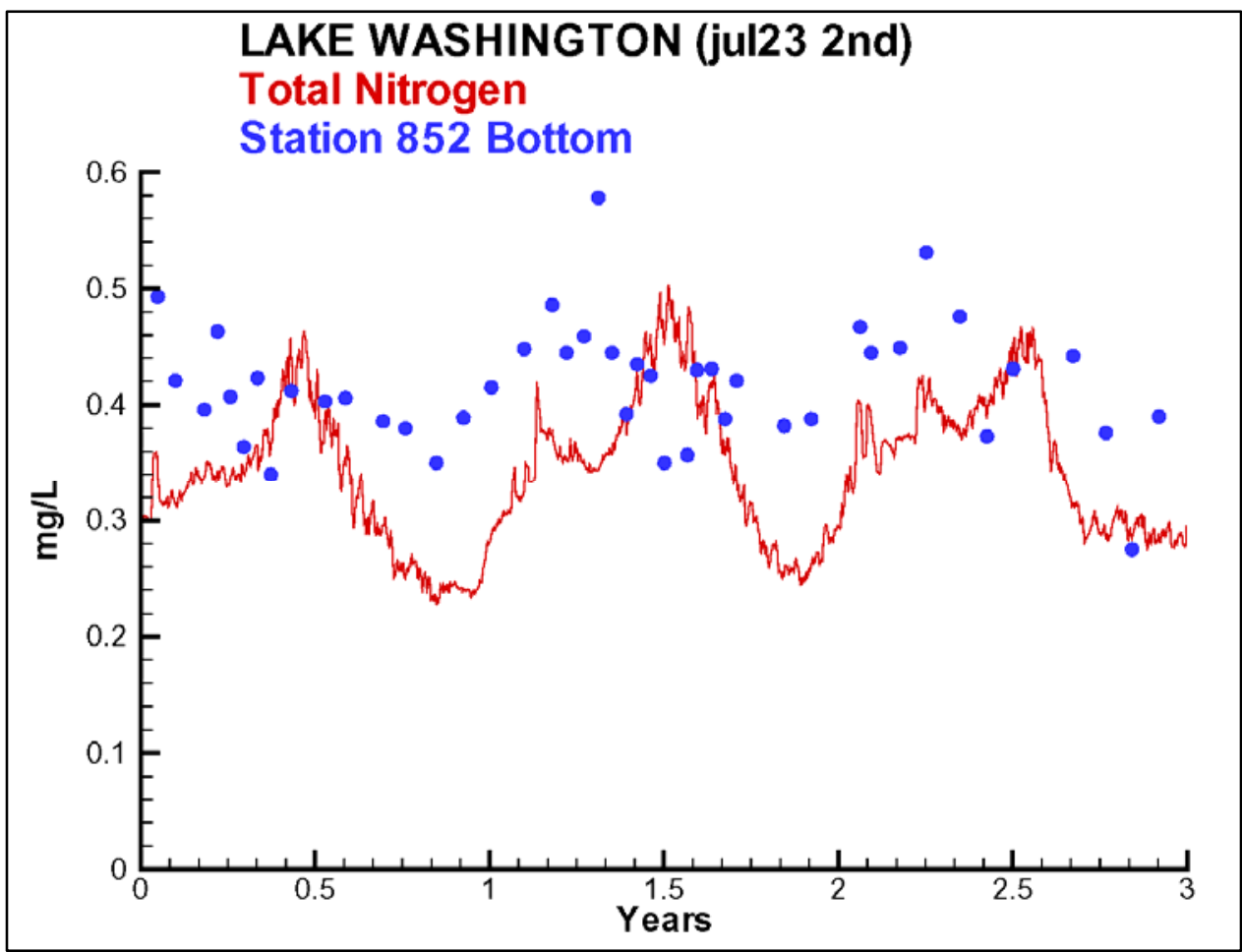

Figure 7-23. Observed and computed bottom total nitrogen at Station 852

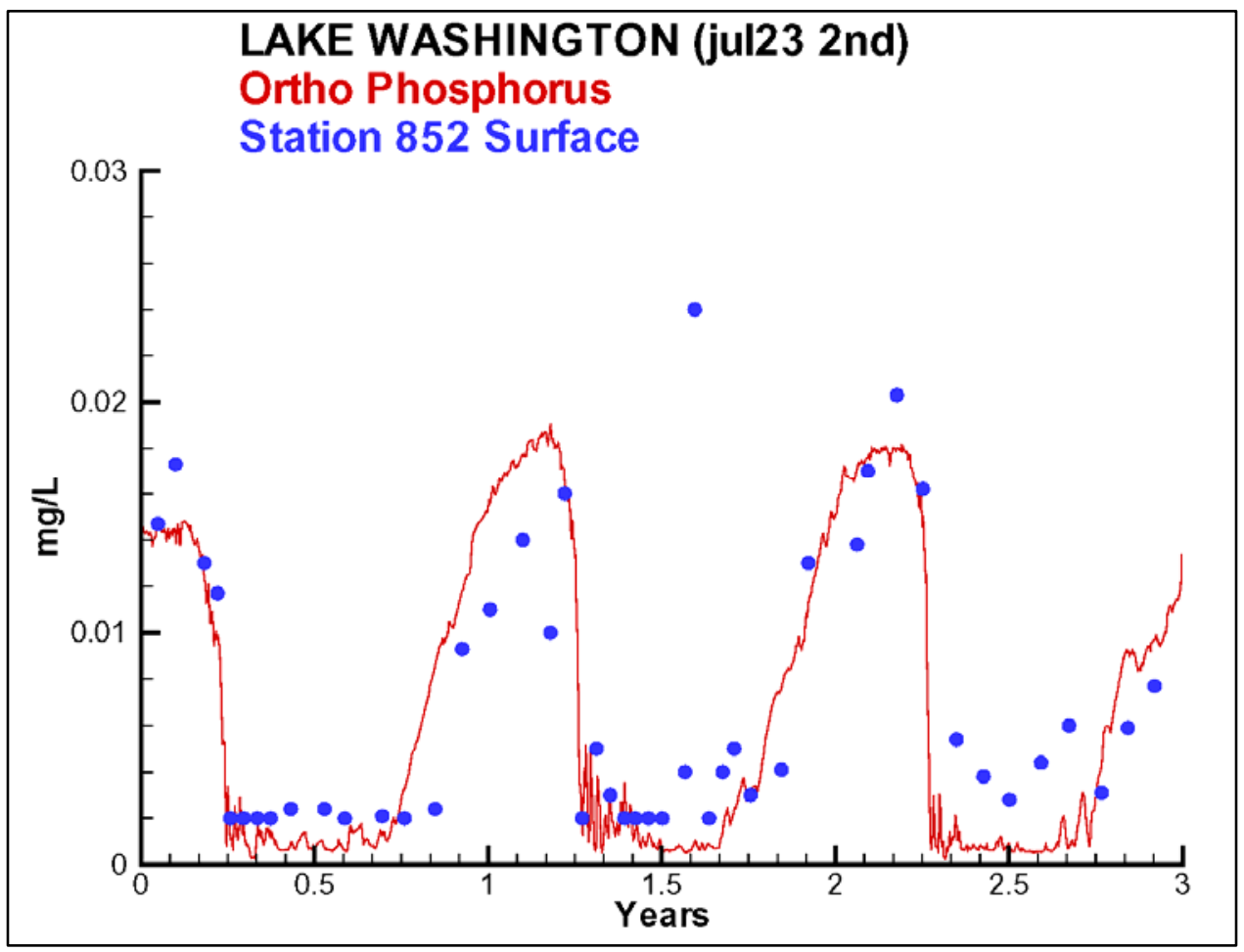

Figure 7-24. Observed and computed surface ortho-phosphorus at Station 852 


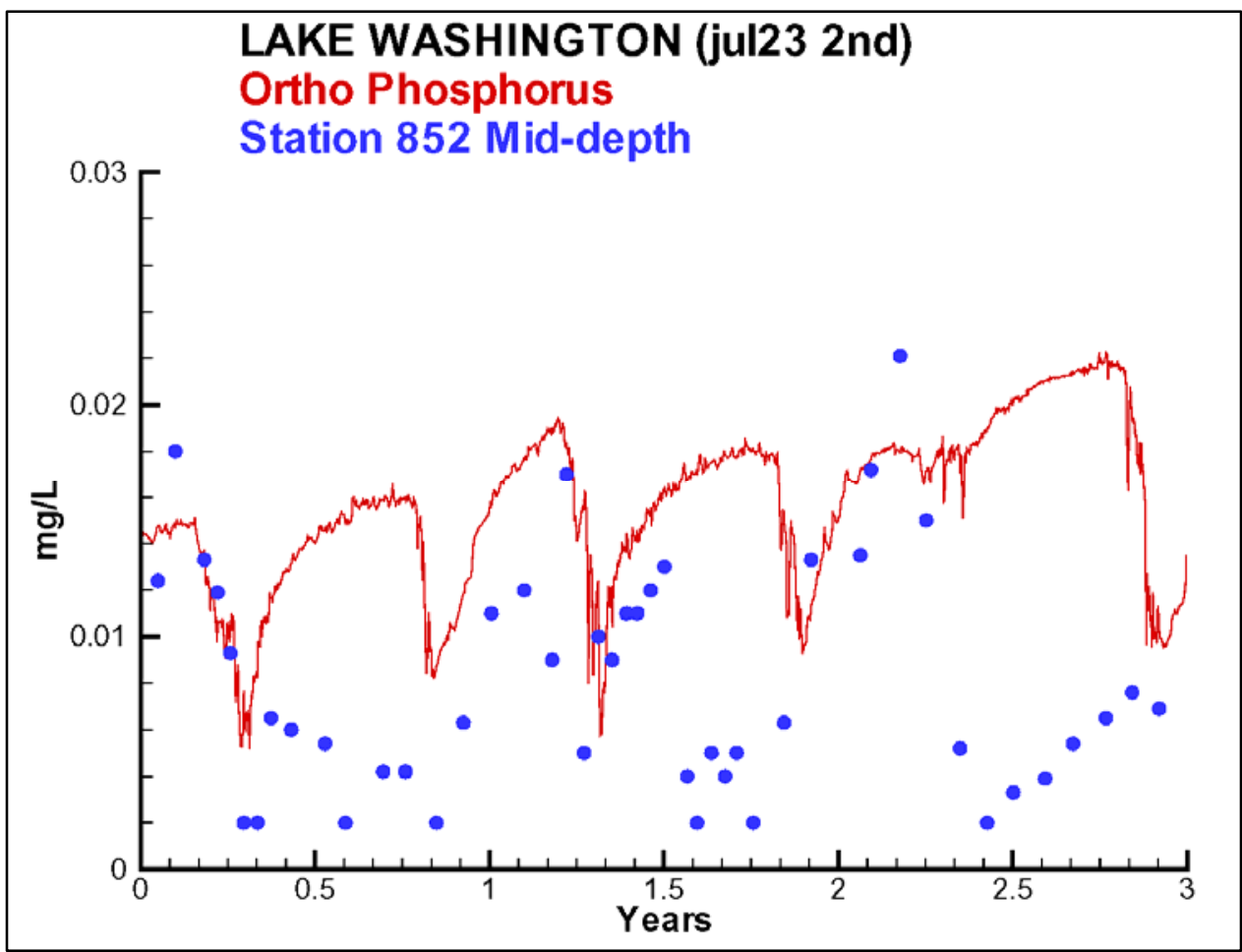

Figure 7-25. Observed and computed middepth ortho-phosphorus at Station 852

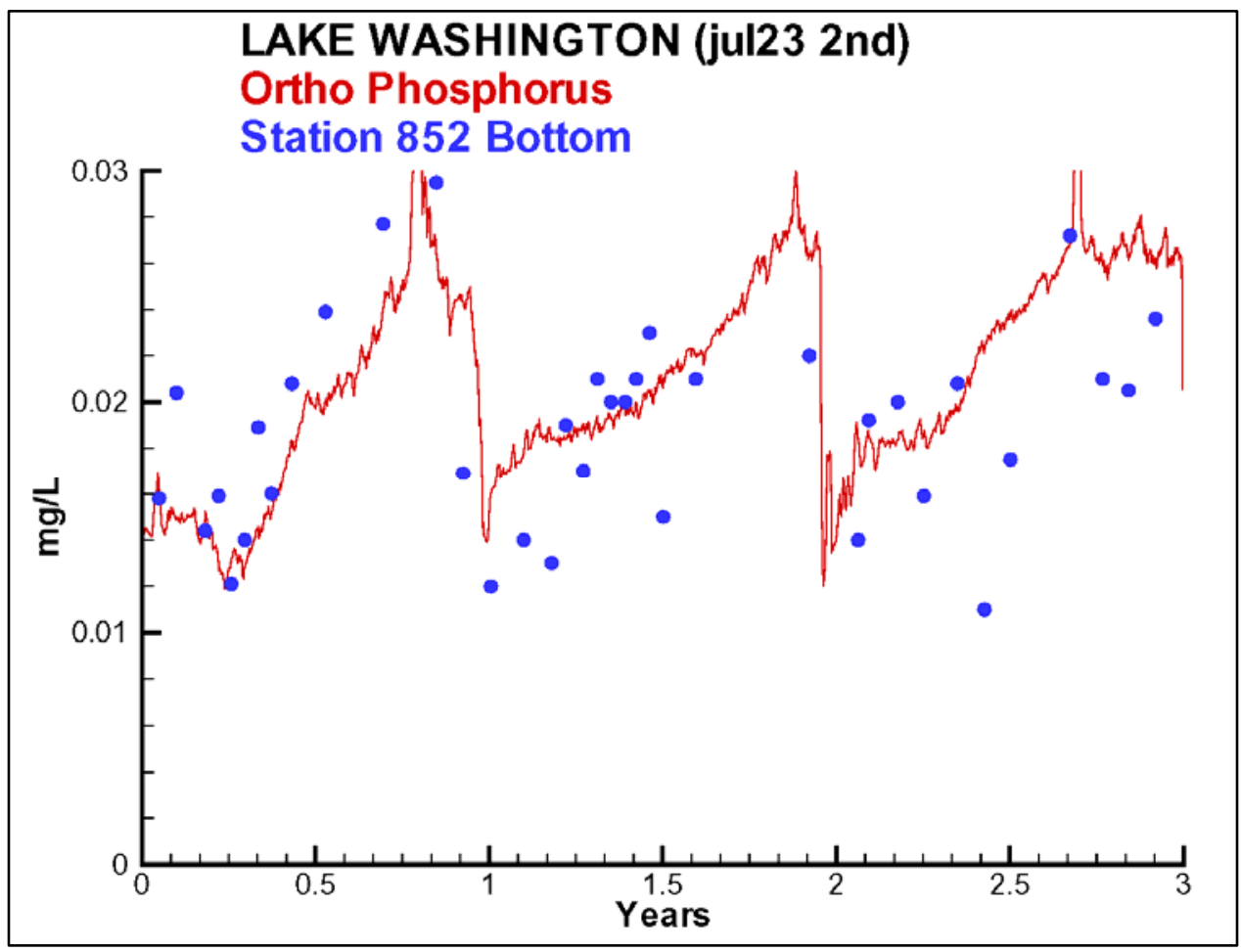

Figure 7-26. Observed and computed bottom ortho-phosphorus at Station 852 


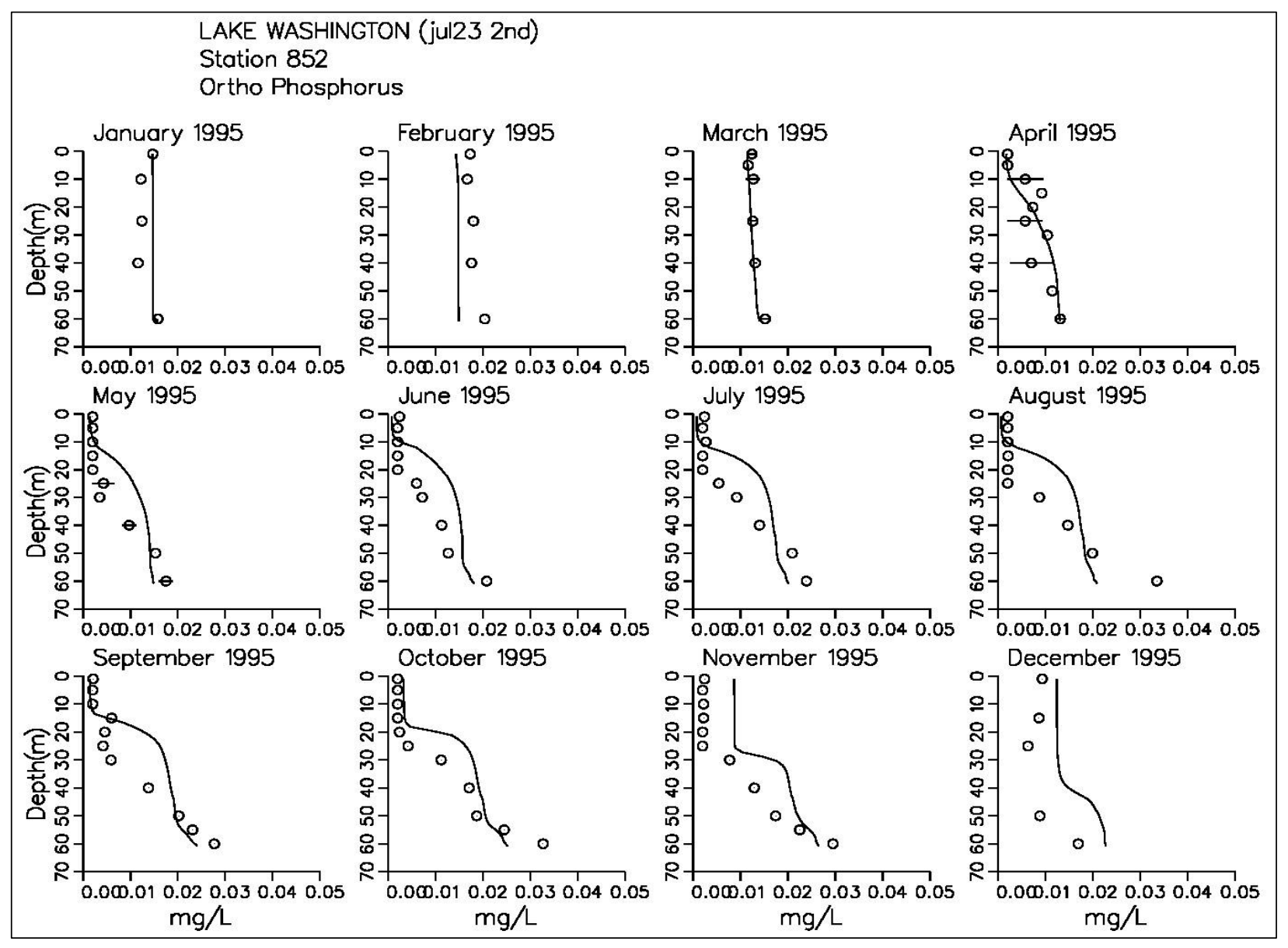

Figure 7-27. Observed and computed bottom ortho-phosphorus at Station 852 for 1995 


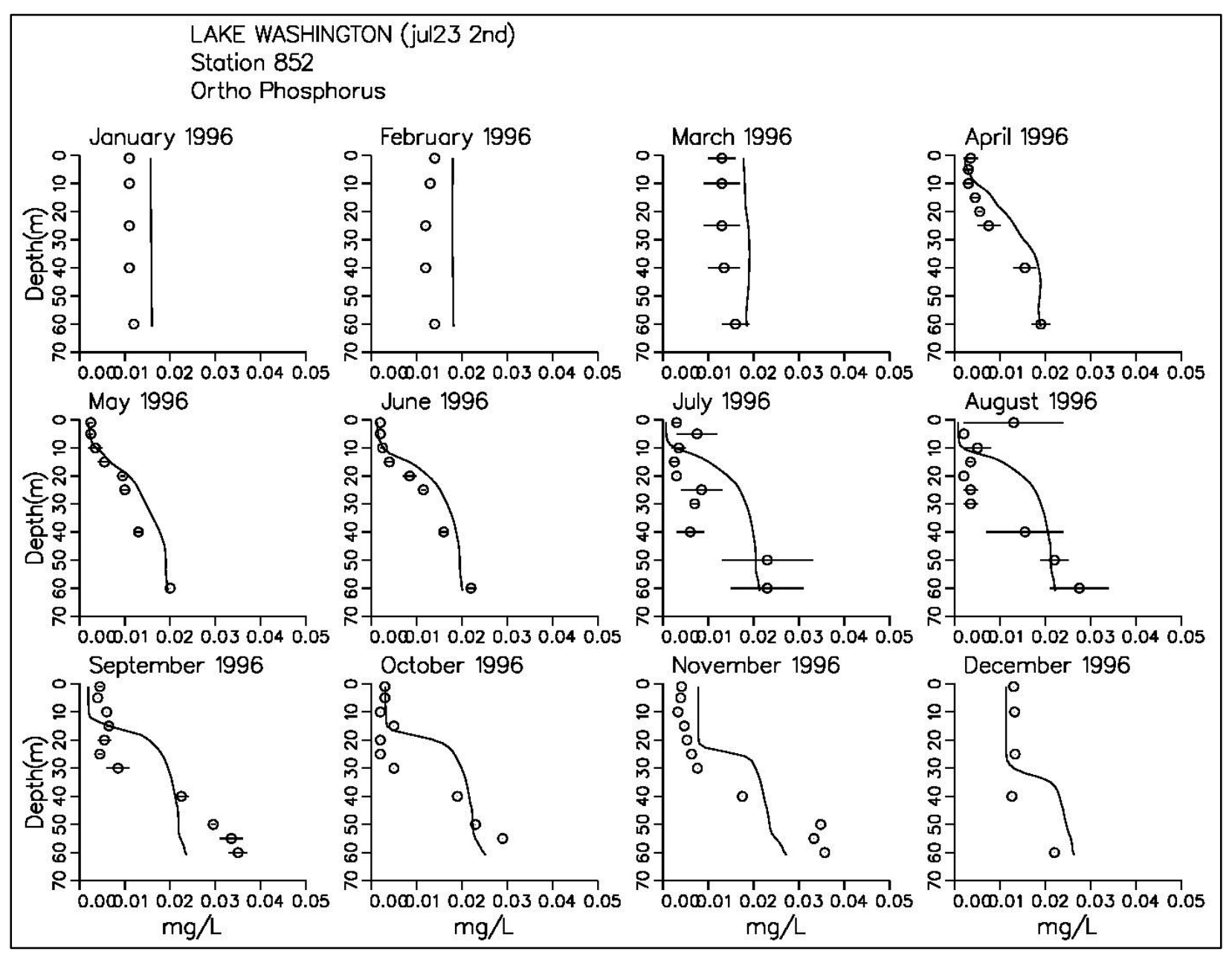

Figure 7-28. Observed and computed ortho-phosphorus profiles at Station 852 for 1996 


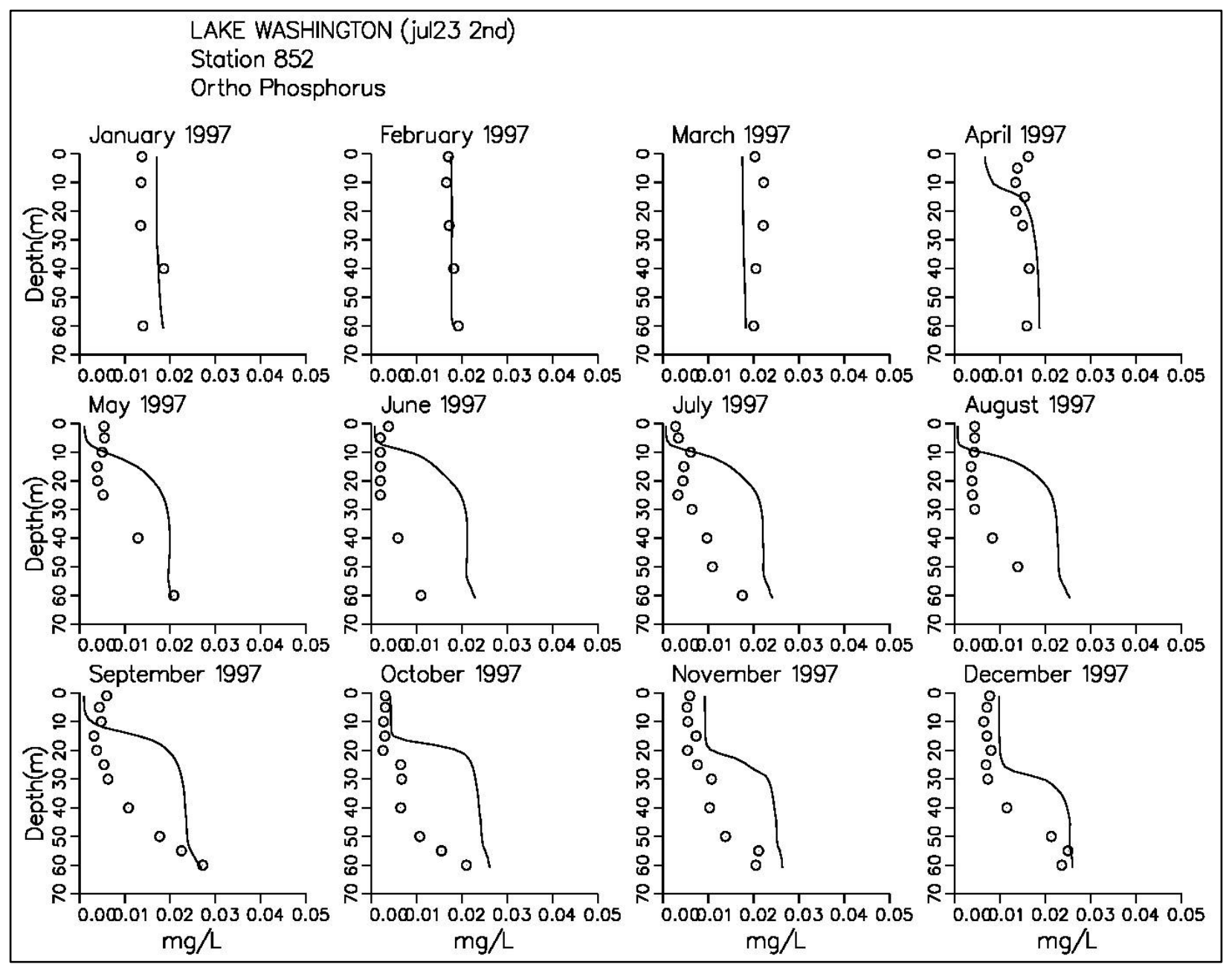

Figure 7-29. Observed and computed ortho-phosphorus profiles at Station 852 for 1997 


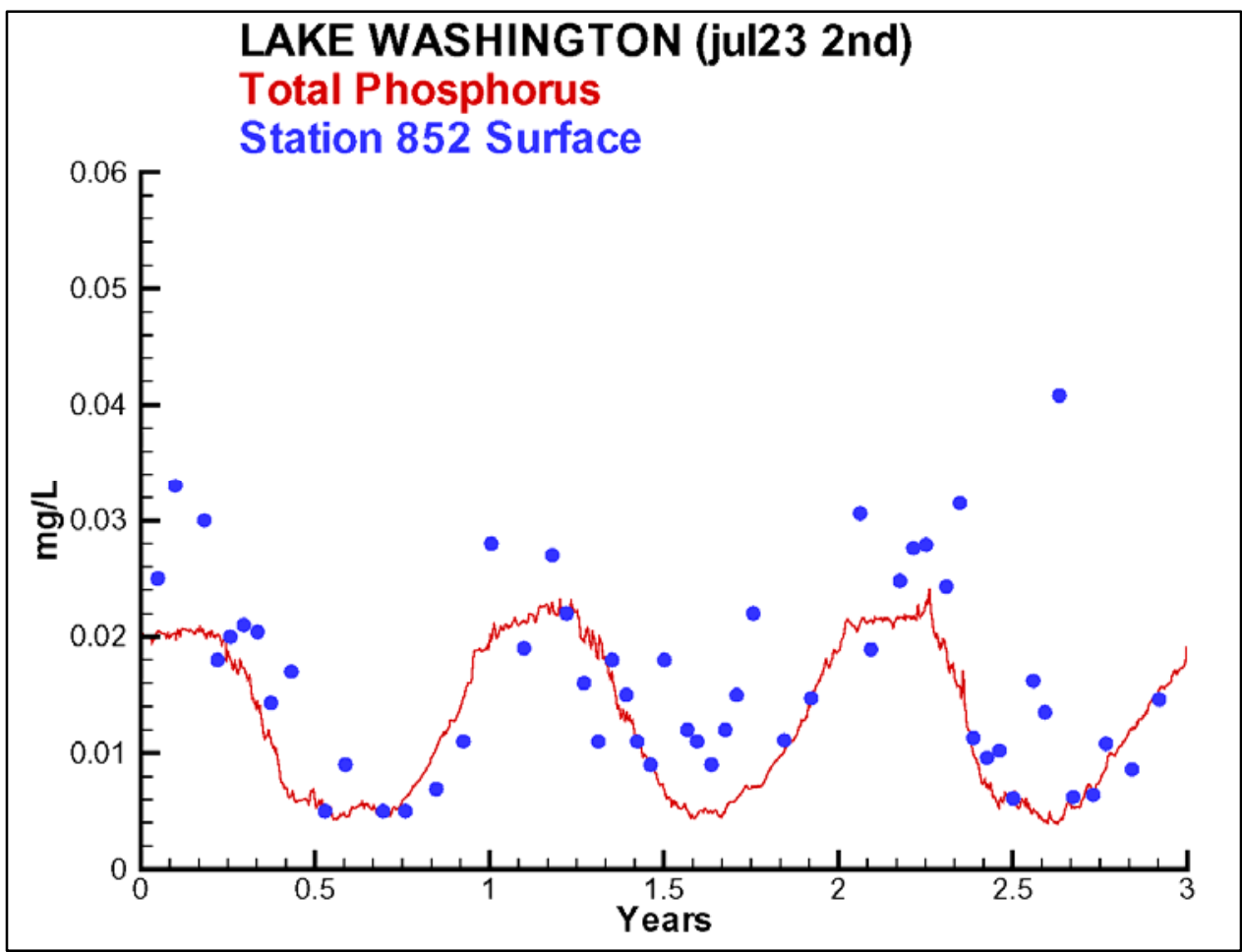

Figure 7-30. Observed and computed surface total phosphorus at Station 852

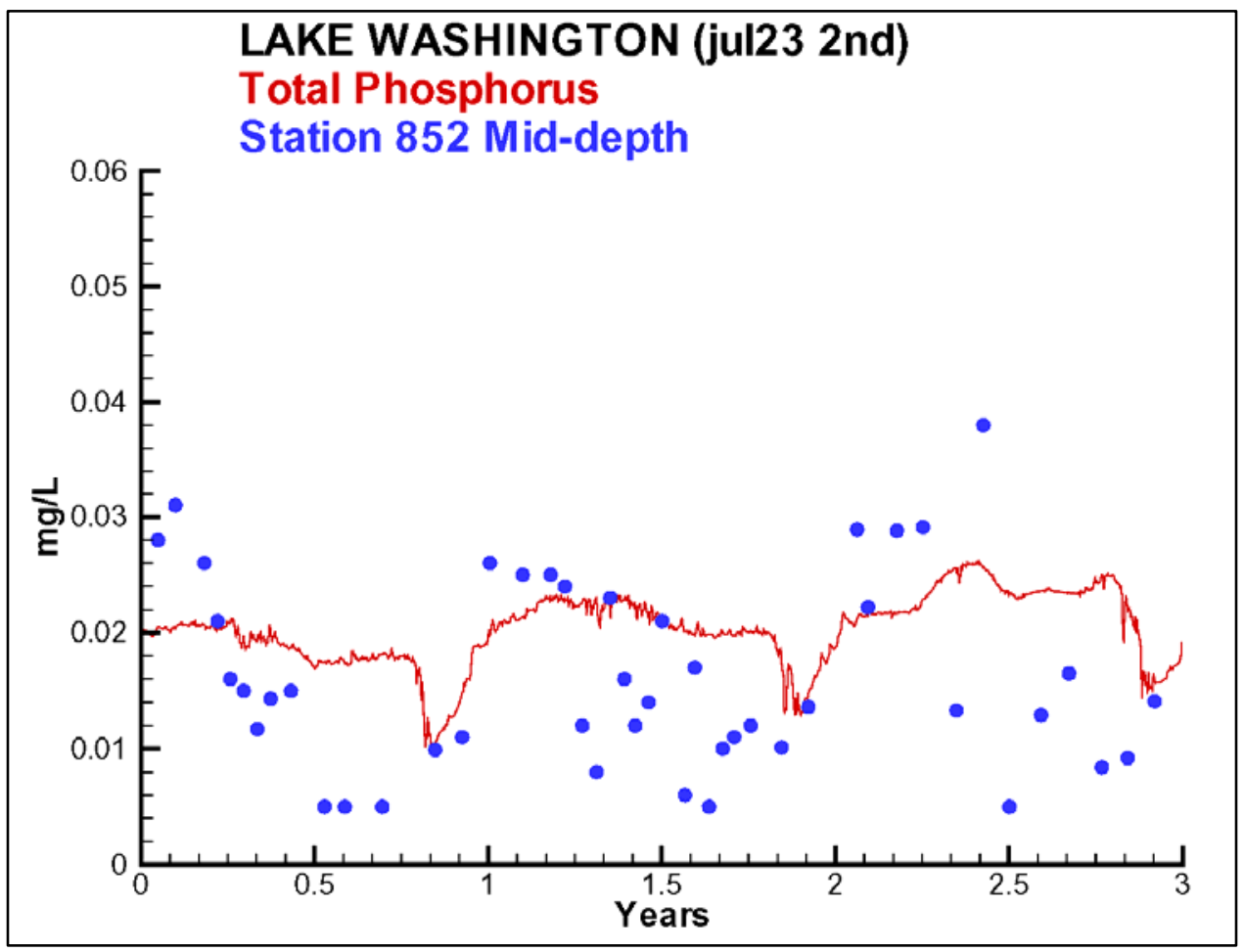

Figure 7-31. Observed and computed middepth total phosphorus at Station 852 


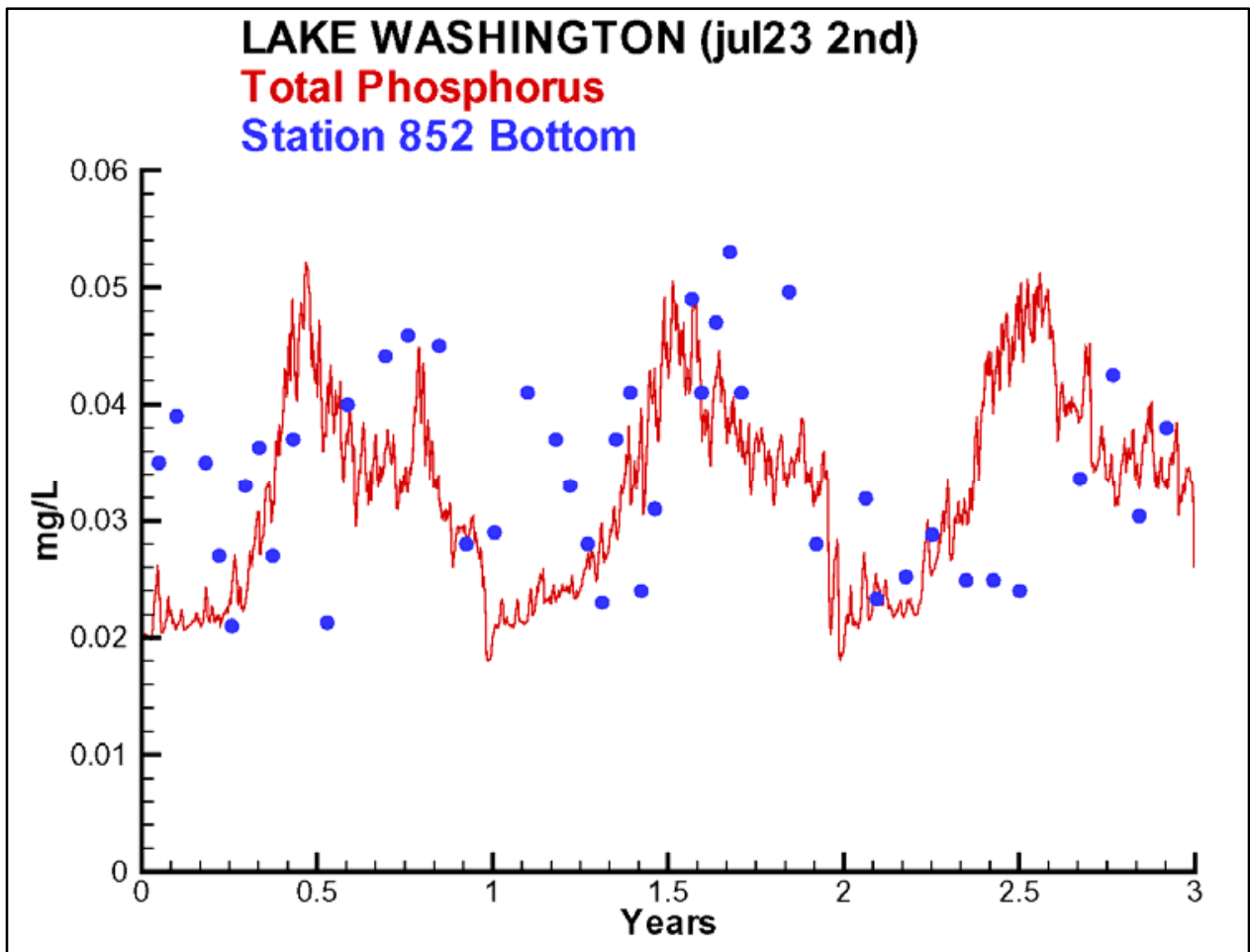

Figure 7-32. Observed and computed bottom total phosphorus at Station 852 


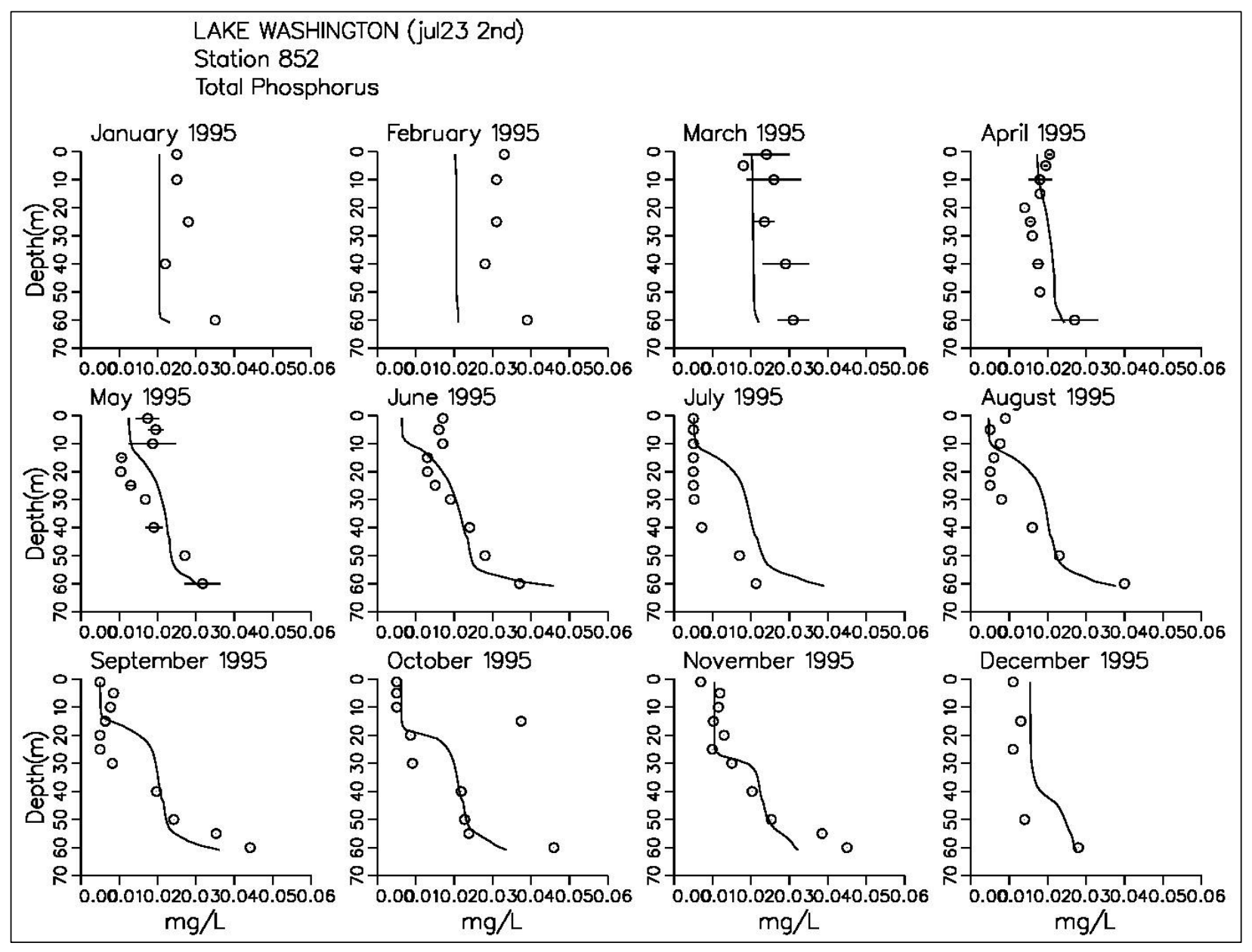

Figure 7-33. Observed and computed total phosphorus profiles at Station 852 for 1995 


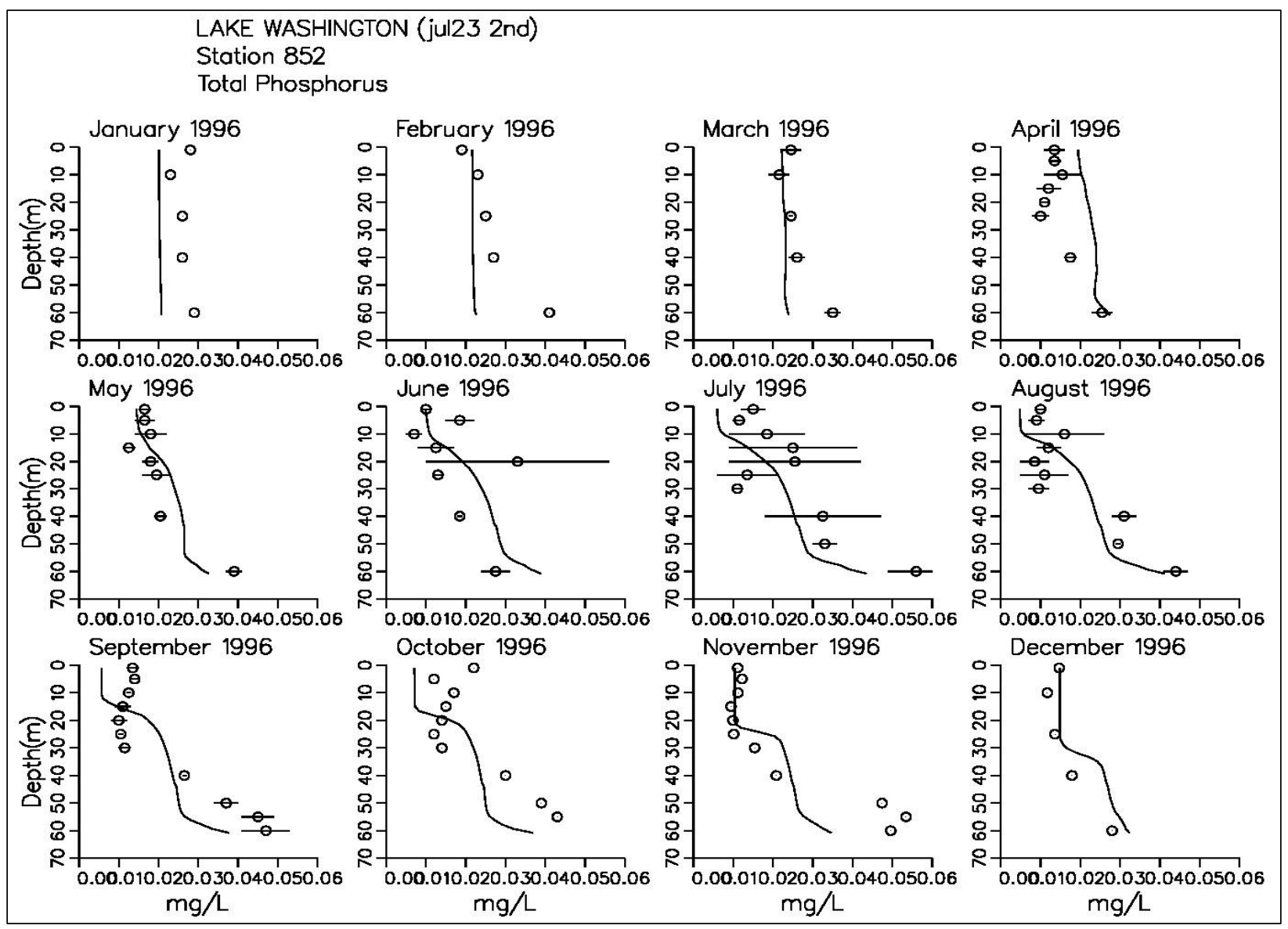

Figure 7-34. Observed and computed total phosphorus profiles at Station 852 for 1996 


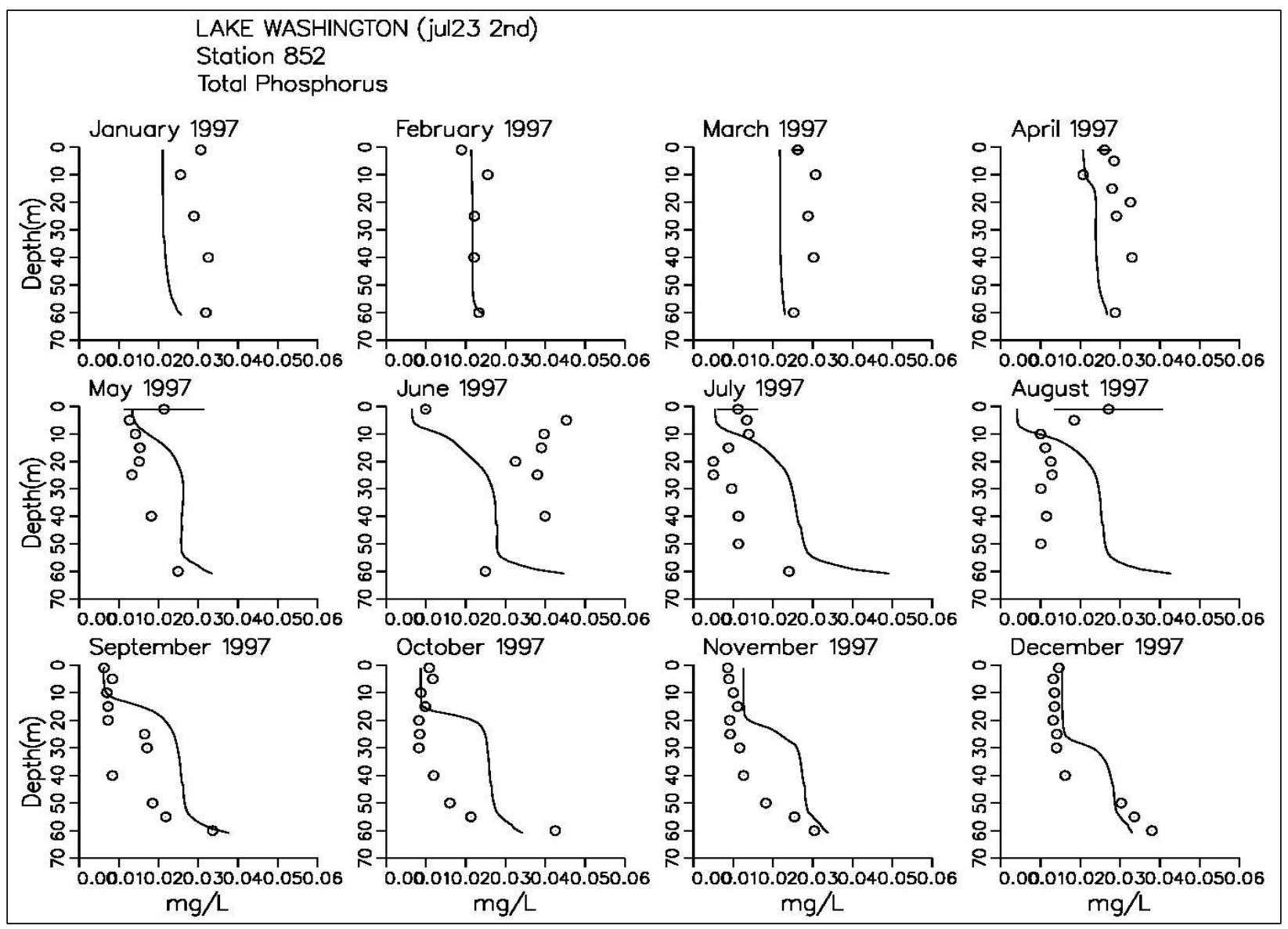

Figure 7-35. Observed and computed total phosphorus profiles at Station 852 for 1997 


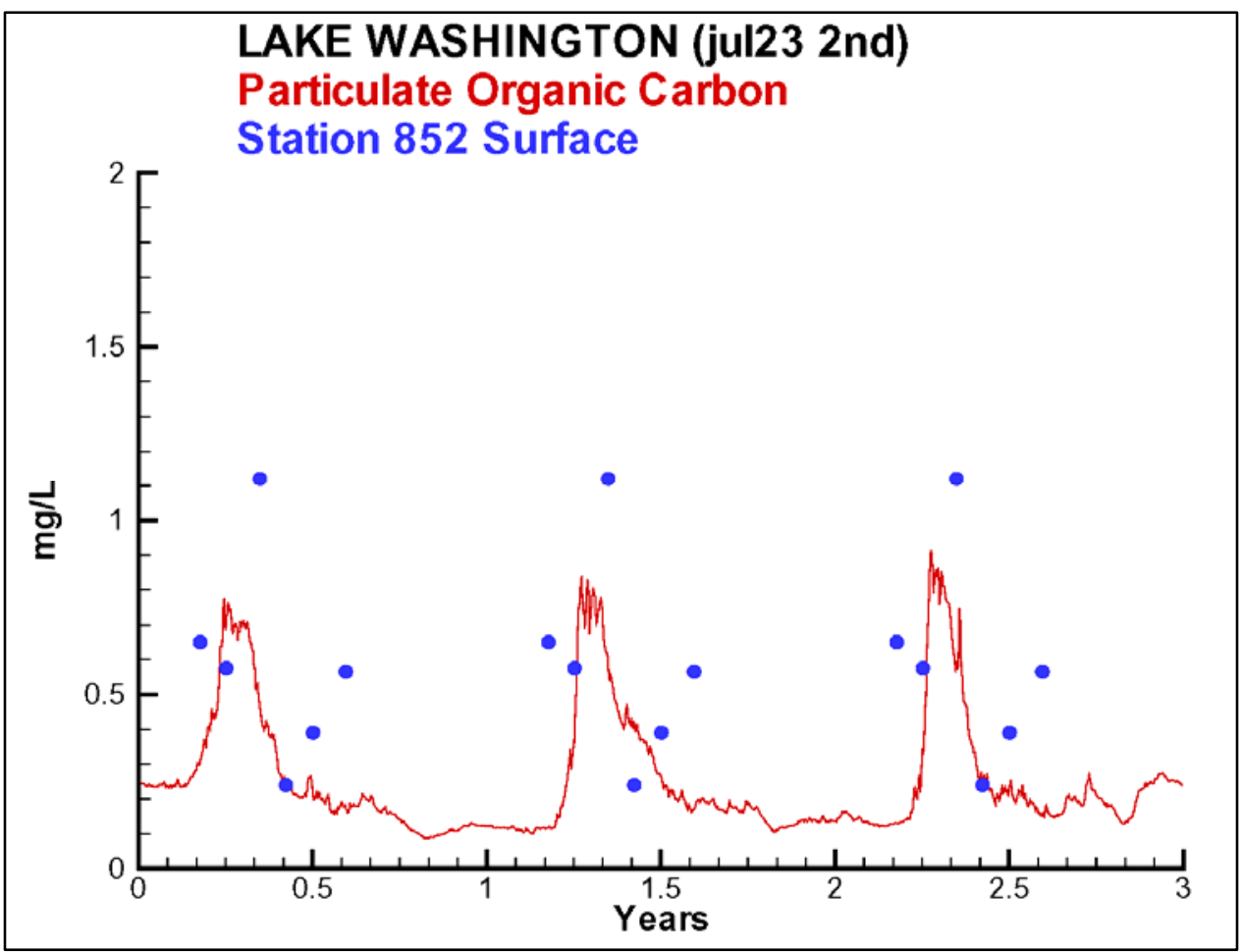

Figure 7-36. Observed and computed surface particulate organic carbon at Station 852

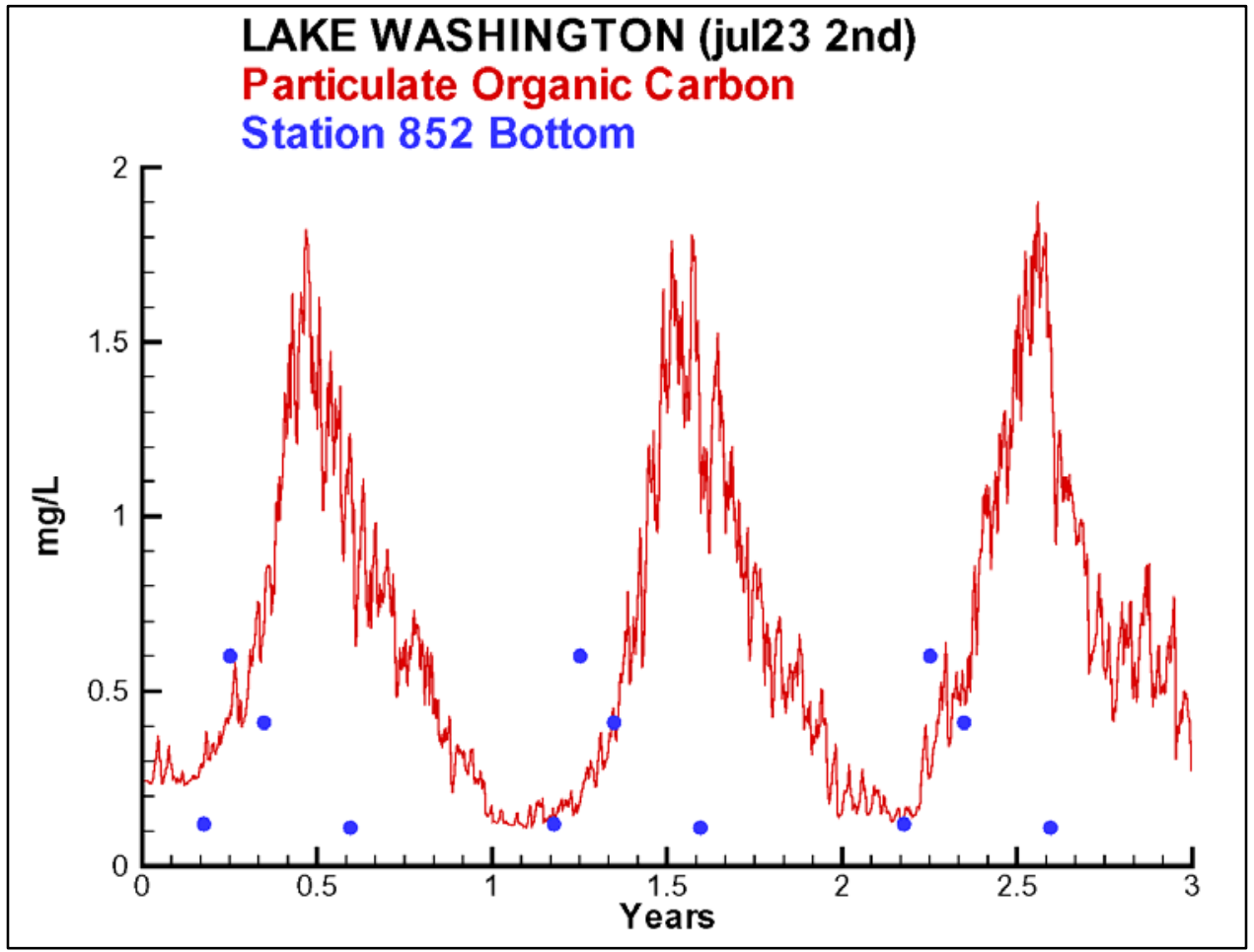

Figure 7-37. Observed and computed bottom particulate organic carbon at Station 852 


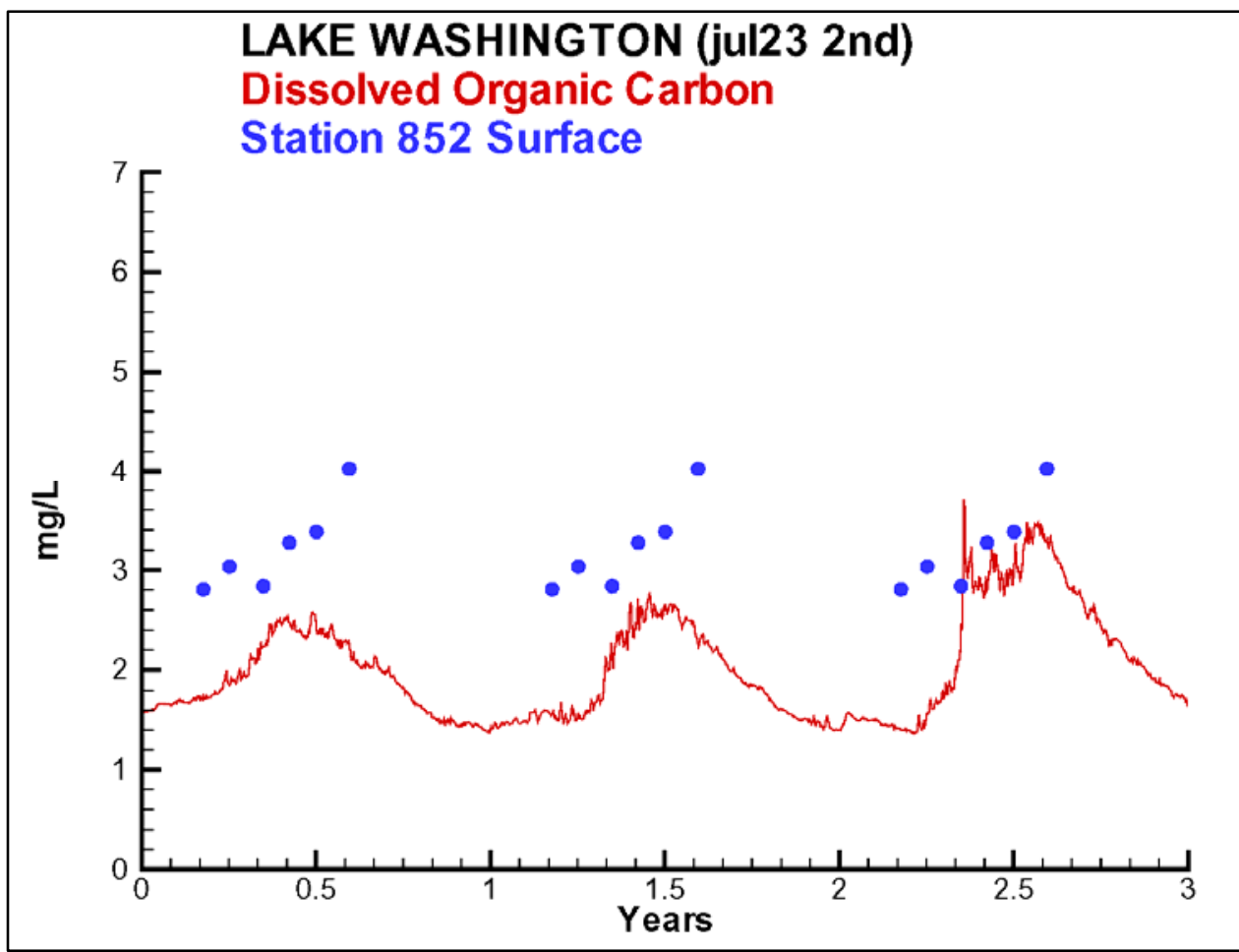

Figure 7-38. Observed and computed surface dissolved organic carbon at Station 852

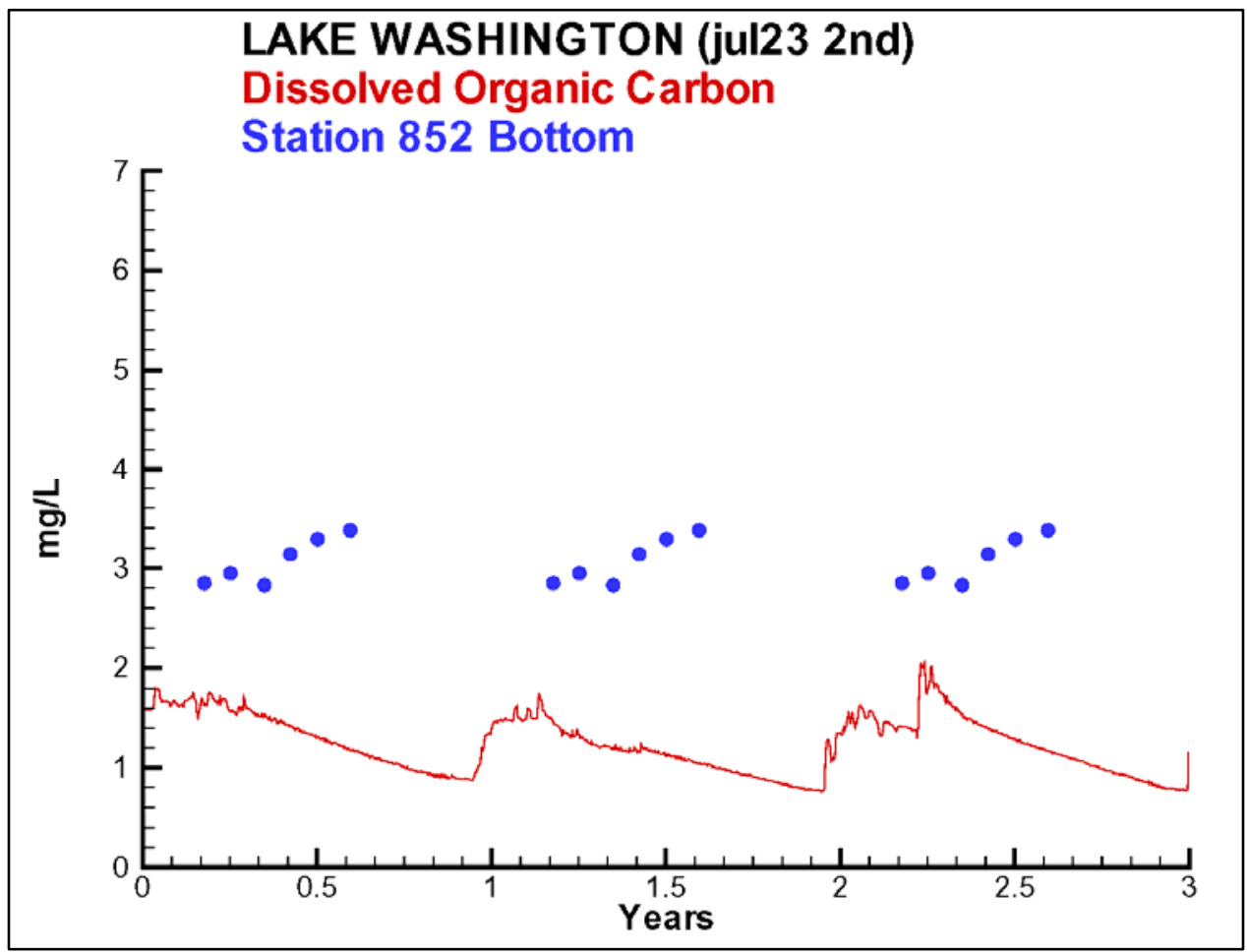

Figure 7-39. Observed and computed bottom dissolved organic carbon at Station 852 


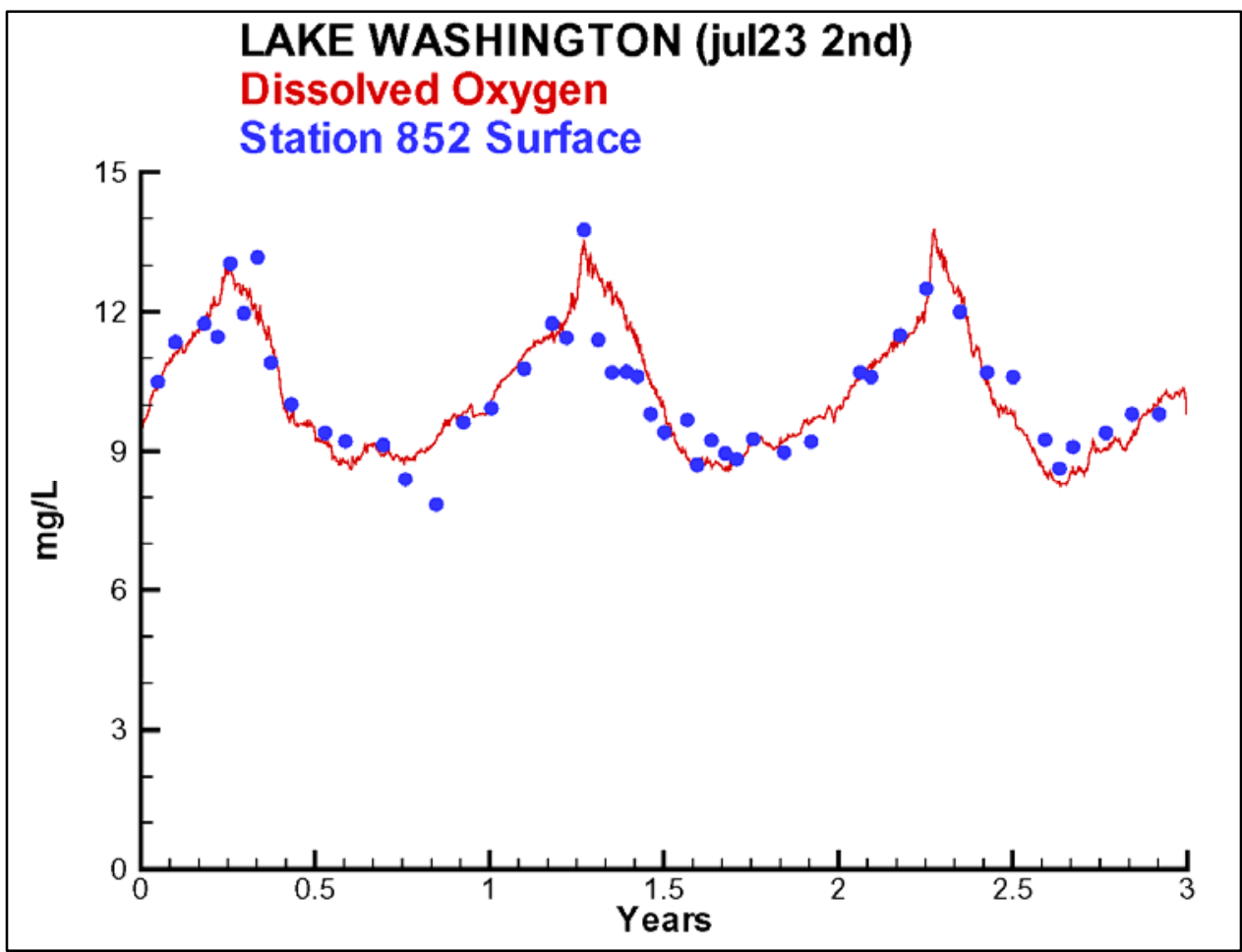

Figure 7-40. Observed and computed surface dissolved oxygen at Station 852

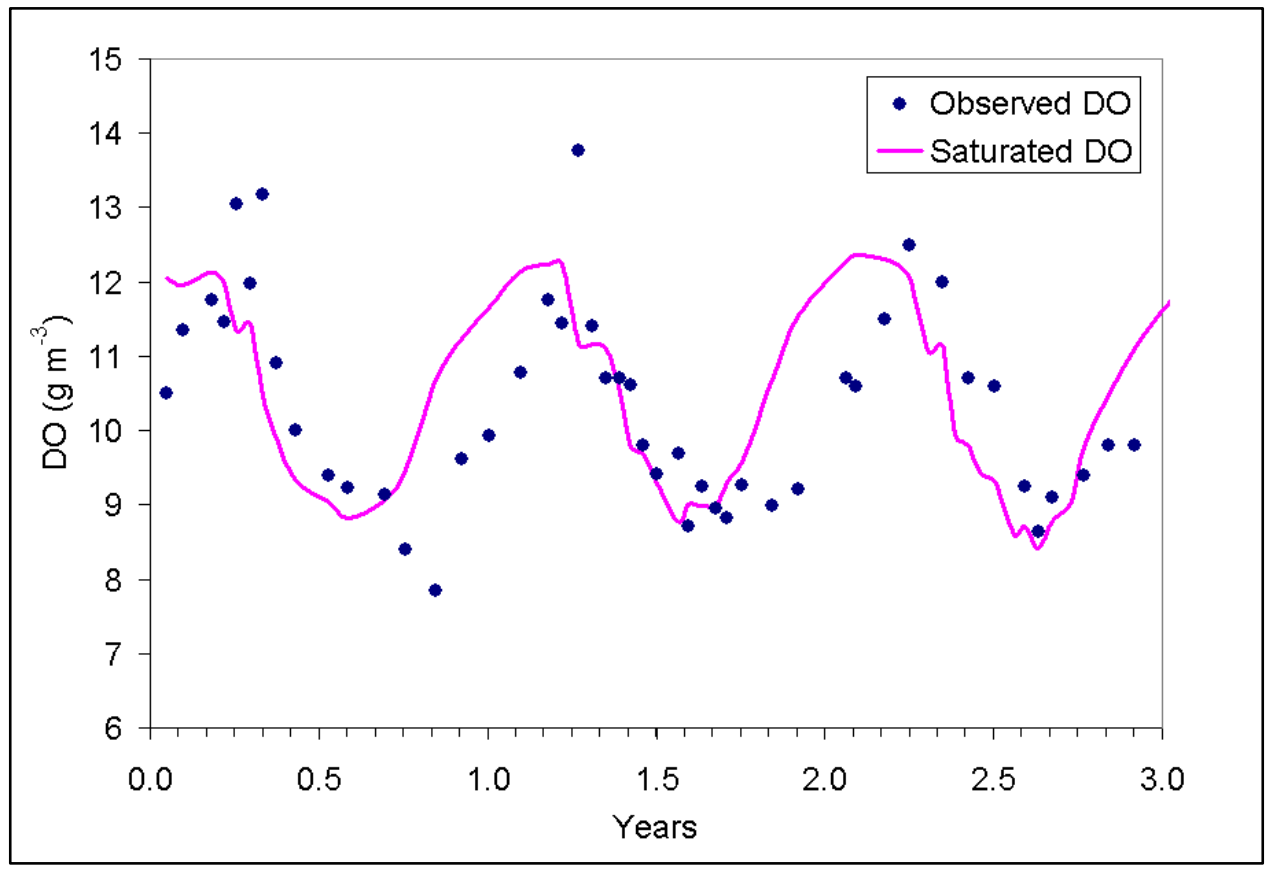

Figure 7-41. Observed and saturated surface dissolved oxygen concentrations at Station 852 


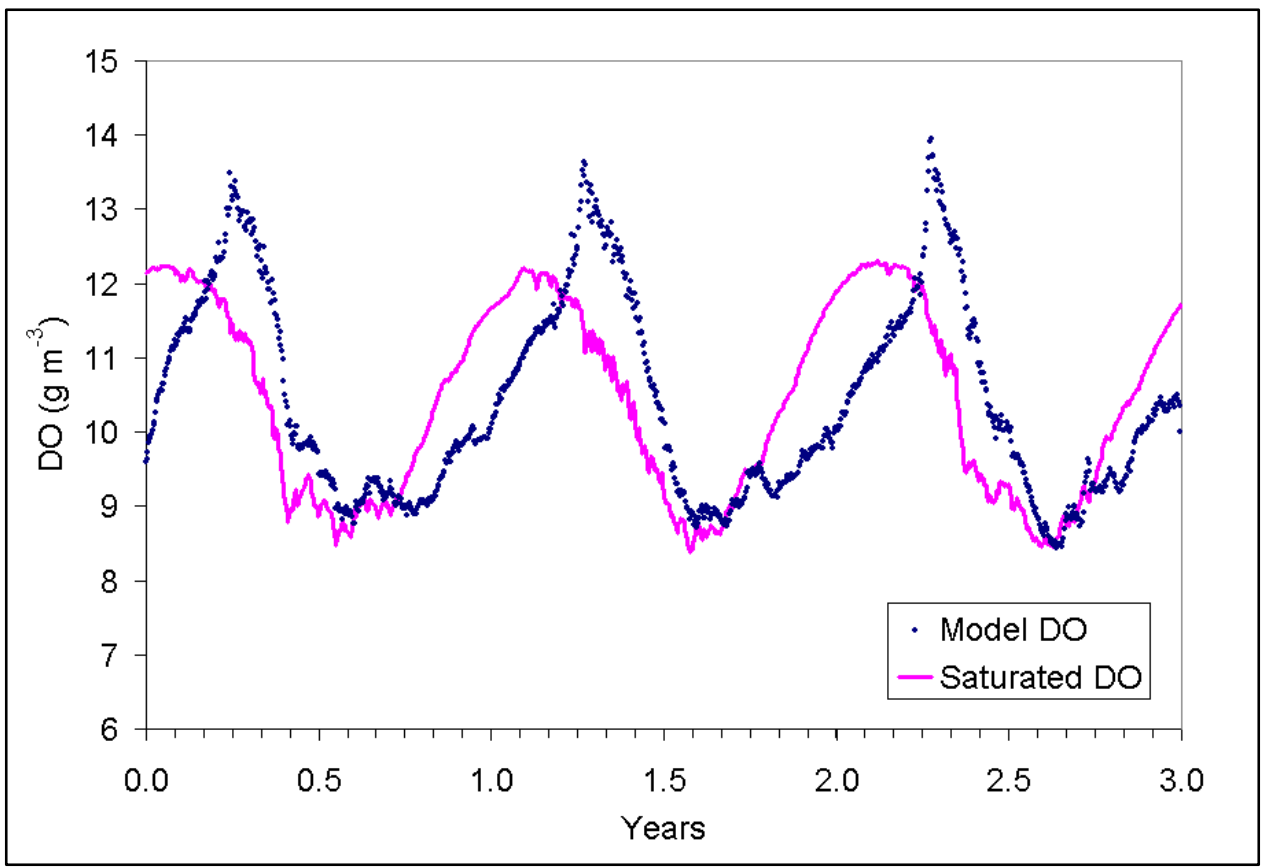

Figure 7-42. Modeled and saturated surface dissolved oxygen concentrations at Station 852

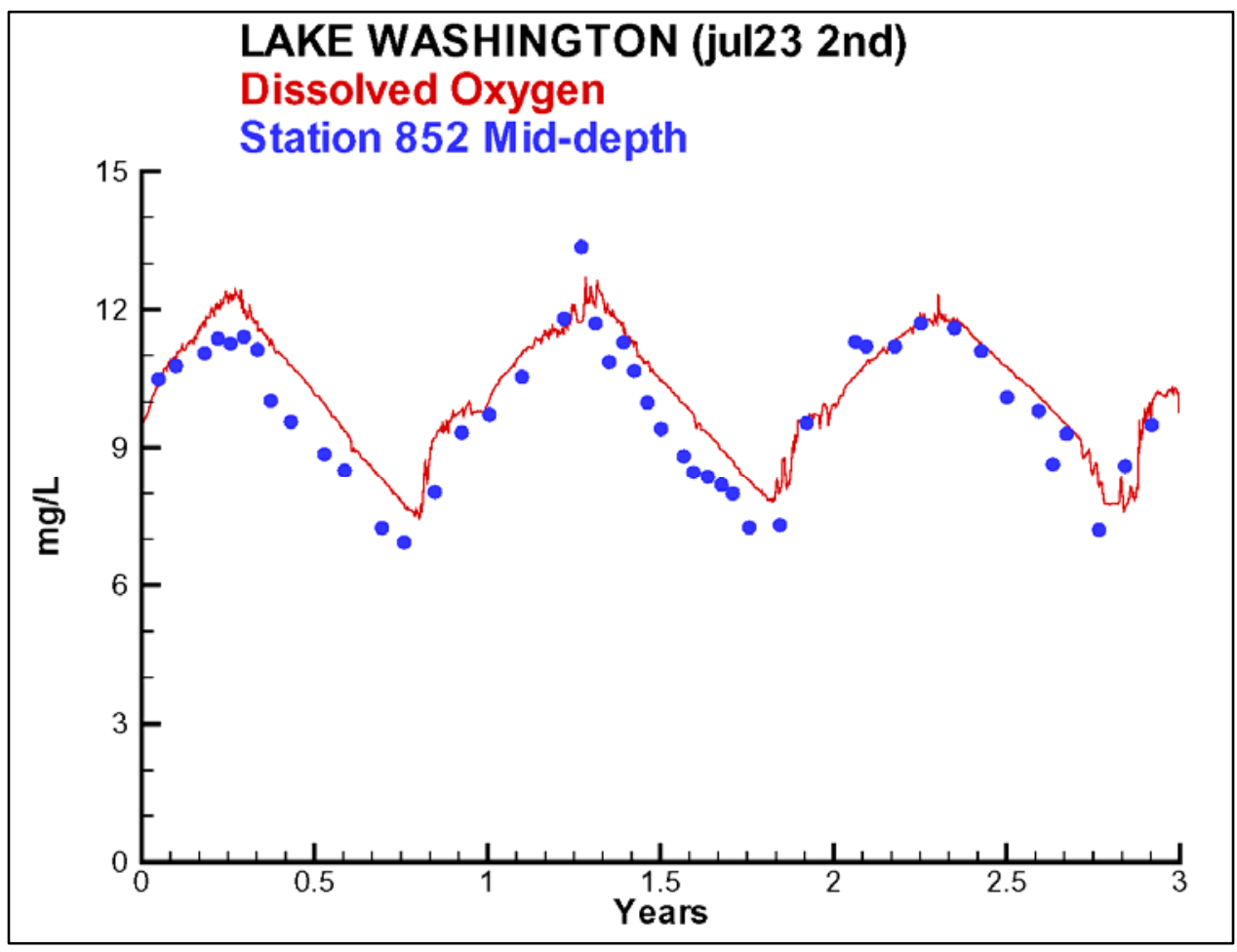

Figure 7-43. Observed and computed middepth dissolved oxygen at Station 852 


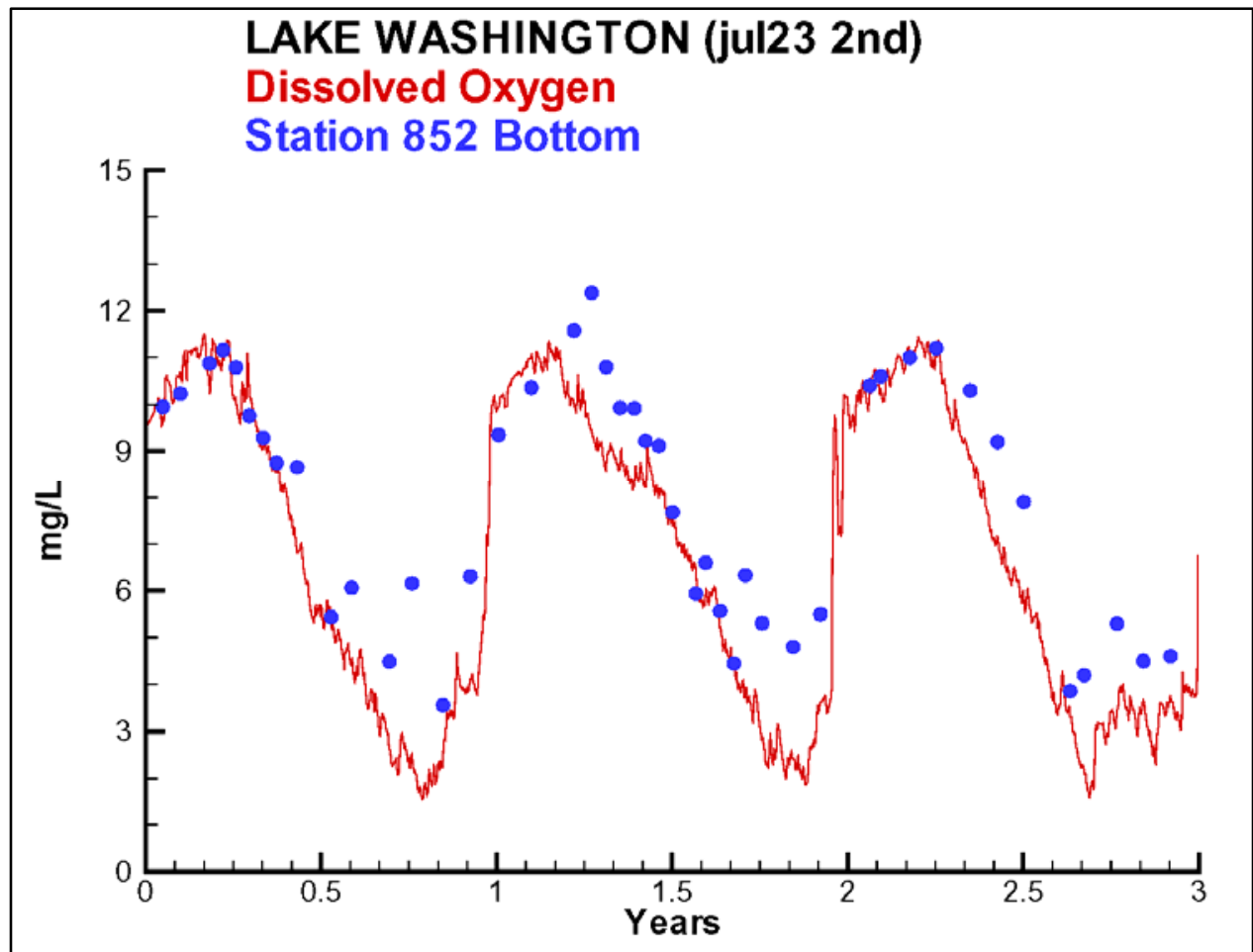

Figure 7-44. Observed and computed bottom dissolved oxygen at Station 852 


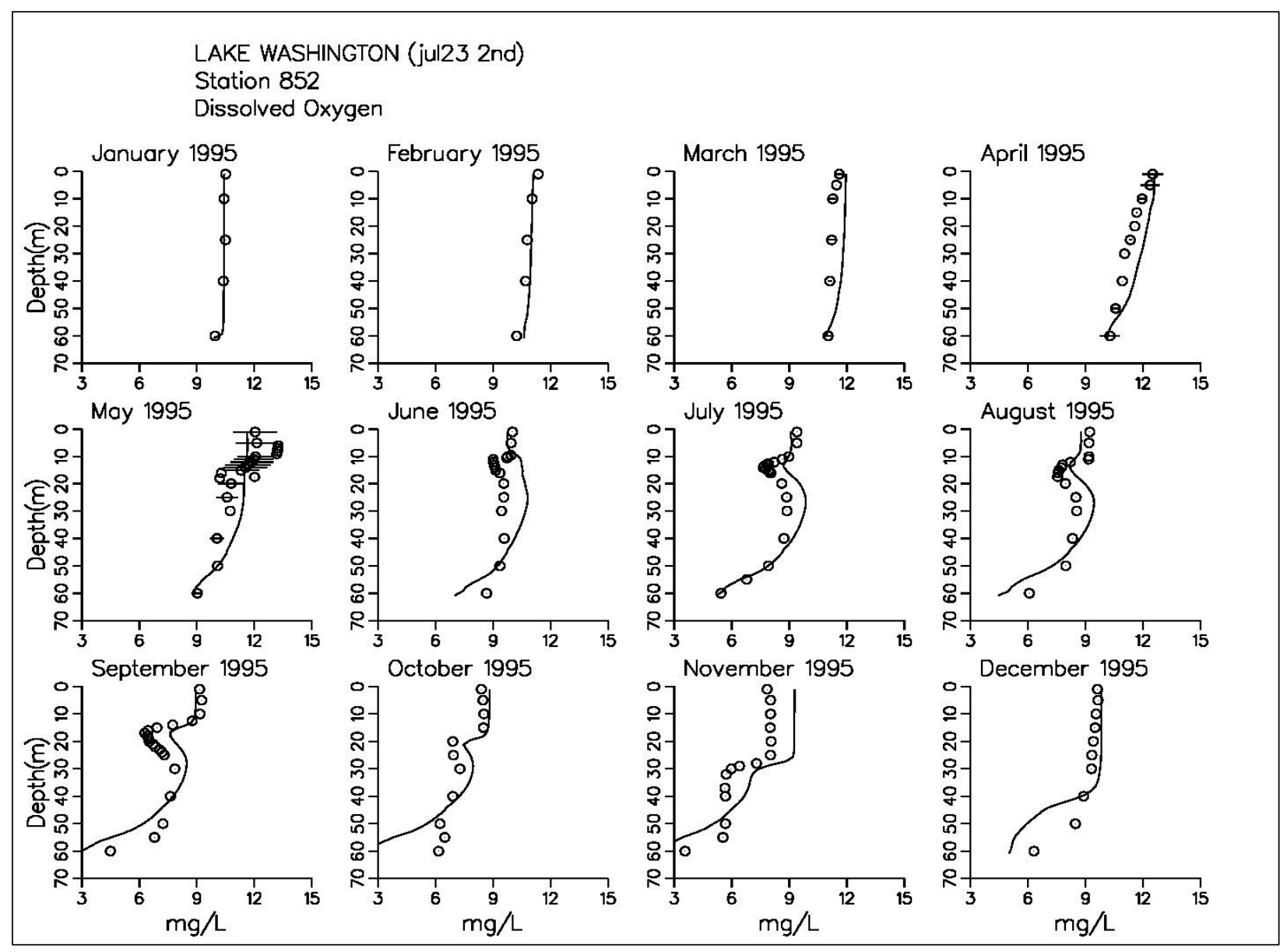

Figure 7-45. Observed and computed dissolved oxygen profiles at Station 852 for 1995 


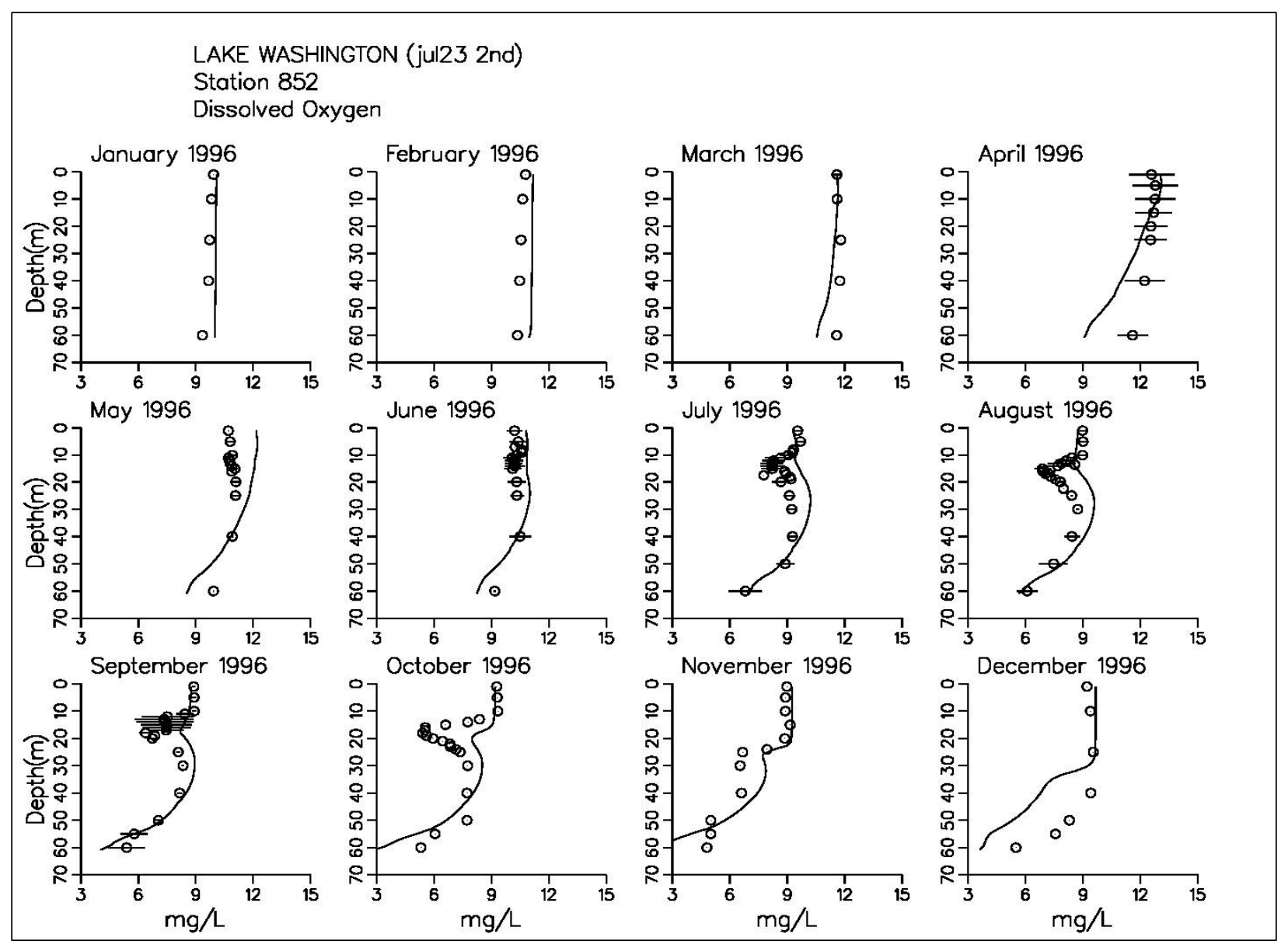

Figure 7-46. Observed and computed dissolved oxygen profiles at Station 852 for 1996 


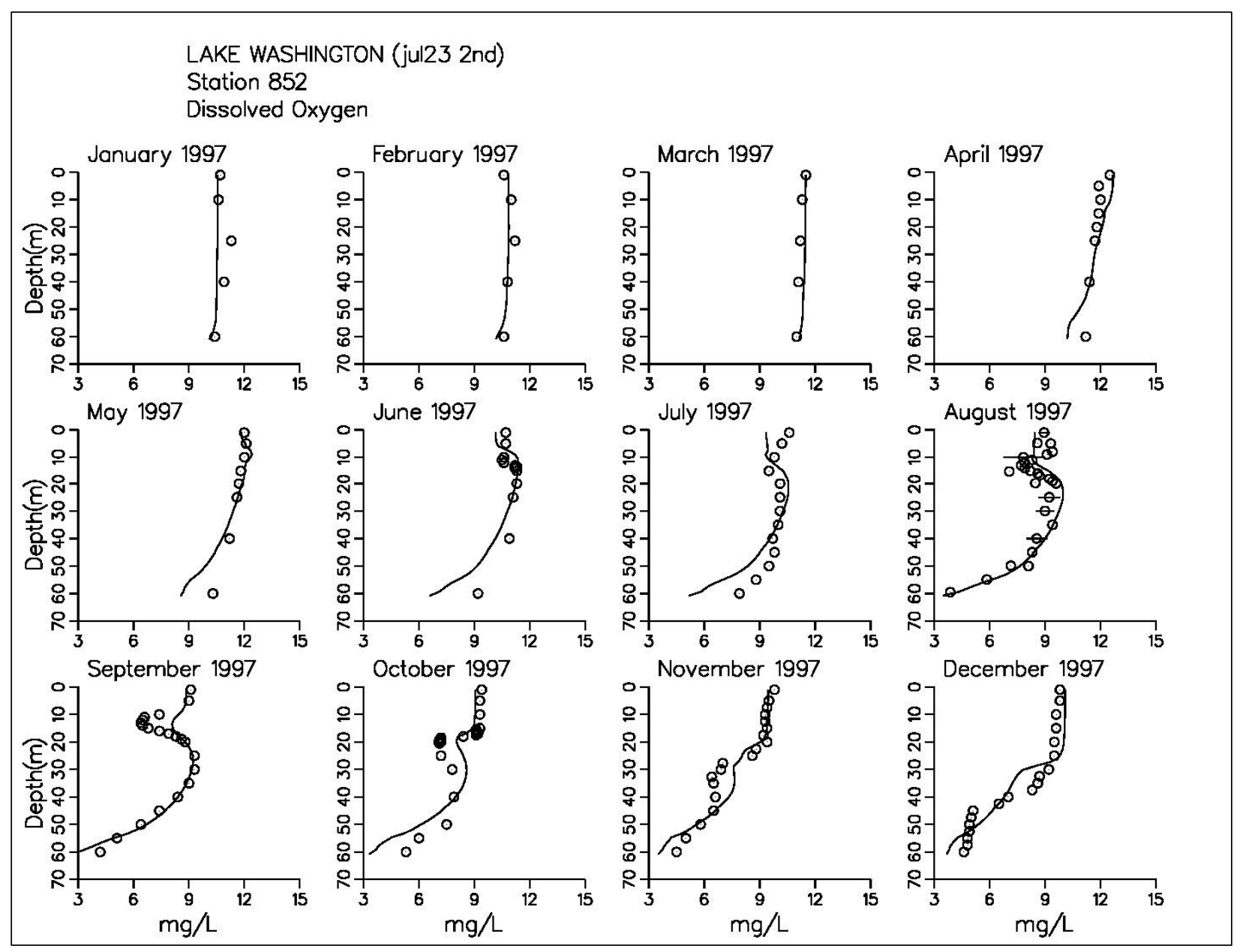

Figure 7-47. Observed and computed dissolved oxygen profiles at Station 852 for 1997 


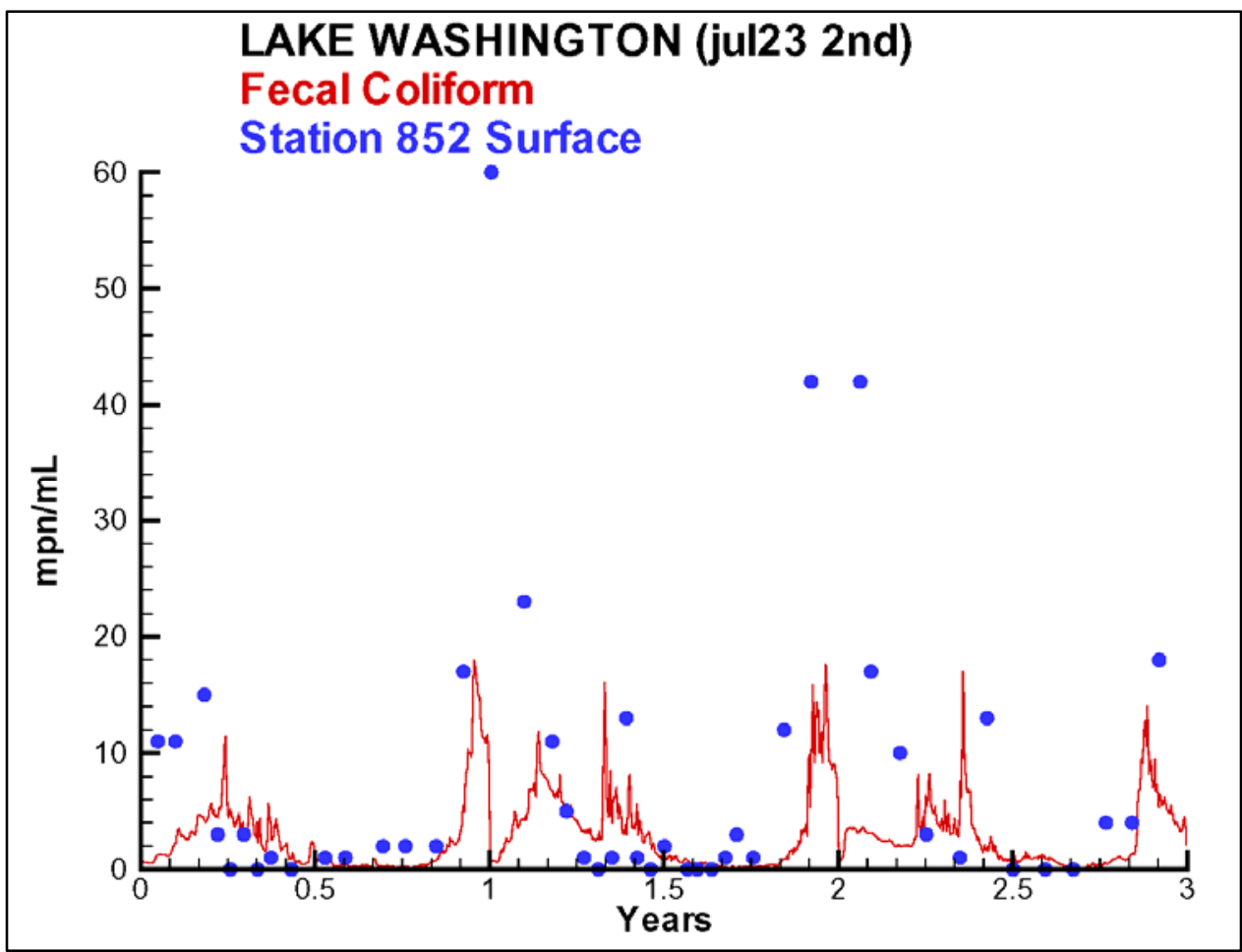

Figure 7-48. Observed and computed surface fecal coliform at Station 852

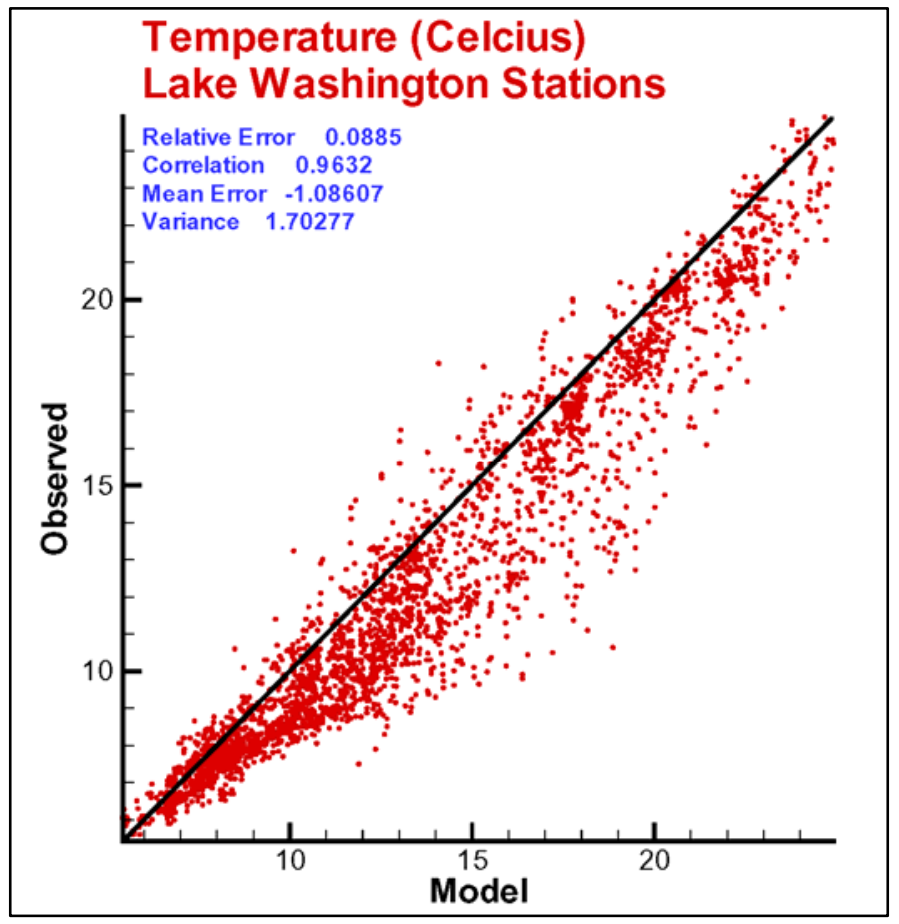

Figure 7-49. Scatterplot of observed and computed temperature at Lake Washington stations 


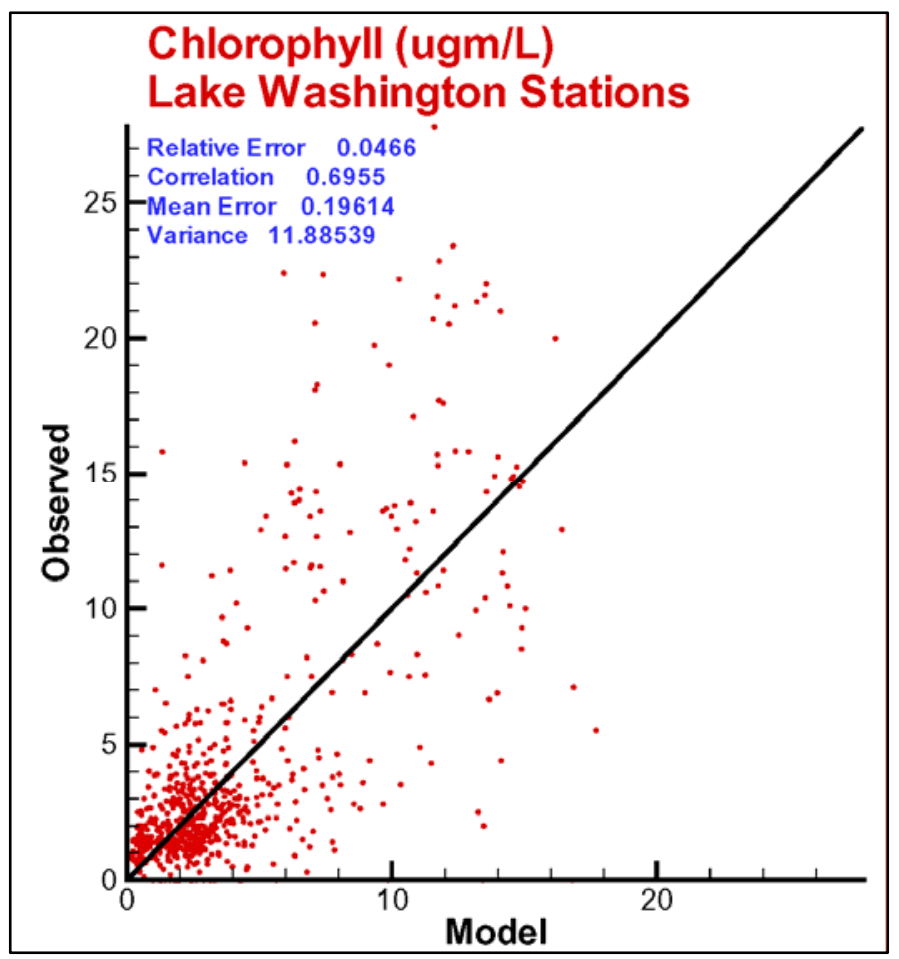

Figure 7-50. Scatterplot of observed and computed chlorophyll at Lake Washington stations

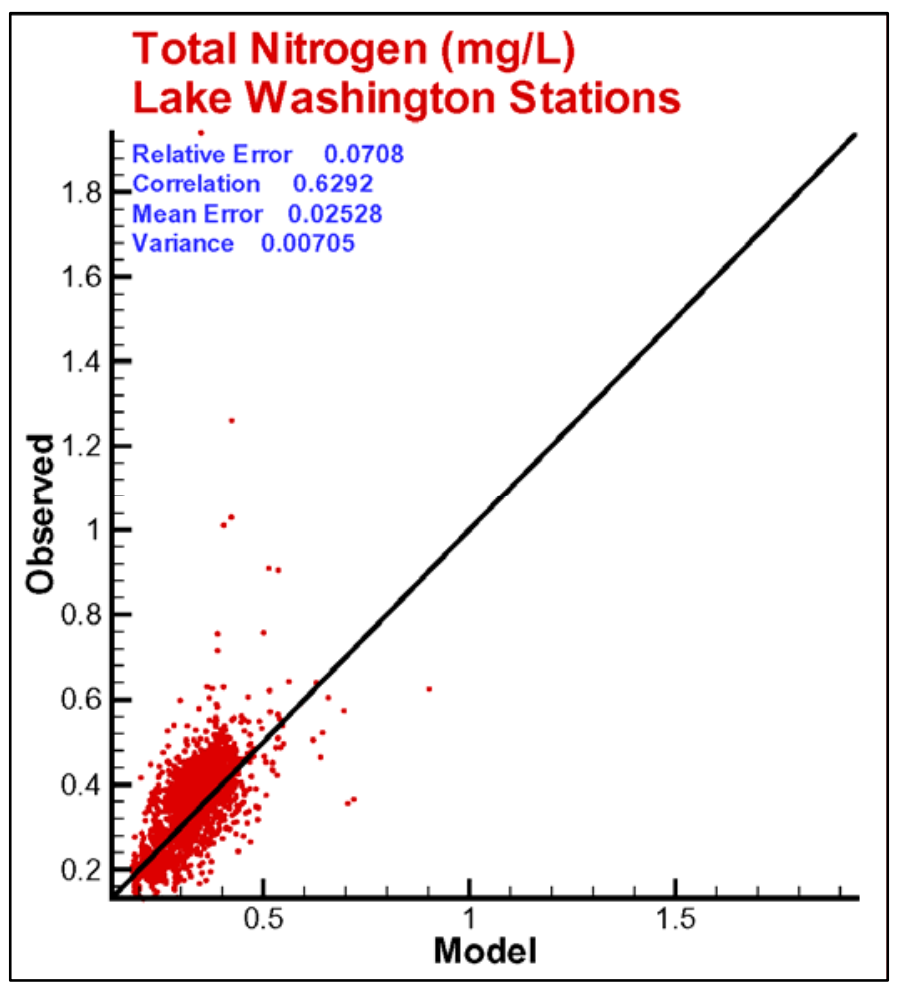

Figure 7-51. Scatterplot of observed and computed total nitrogen at Lake Washington stations 


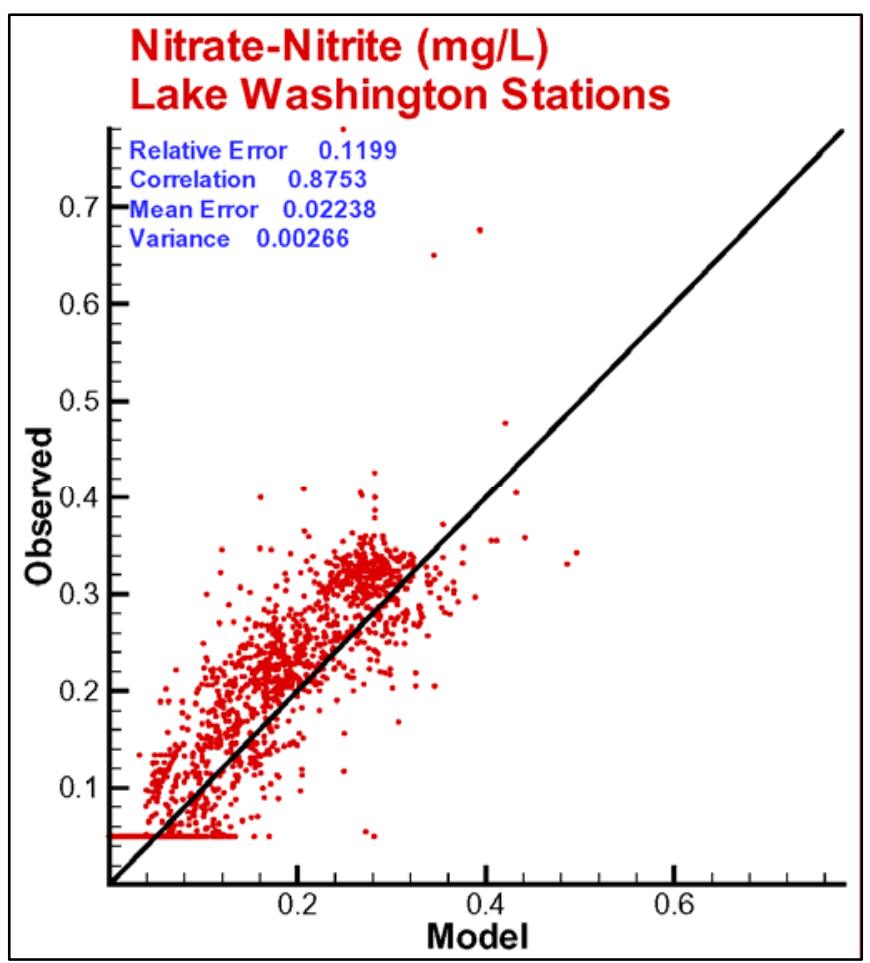

Figure 7-52. Scatterplot of observed and computed nitrate at Lake Washington stations

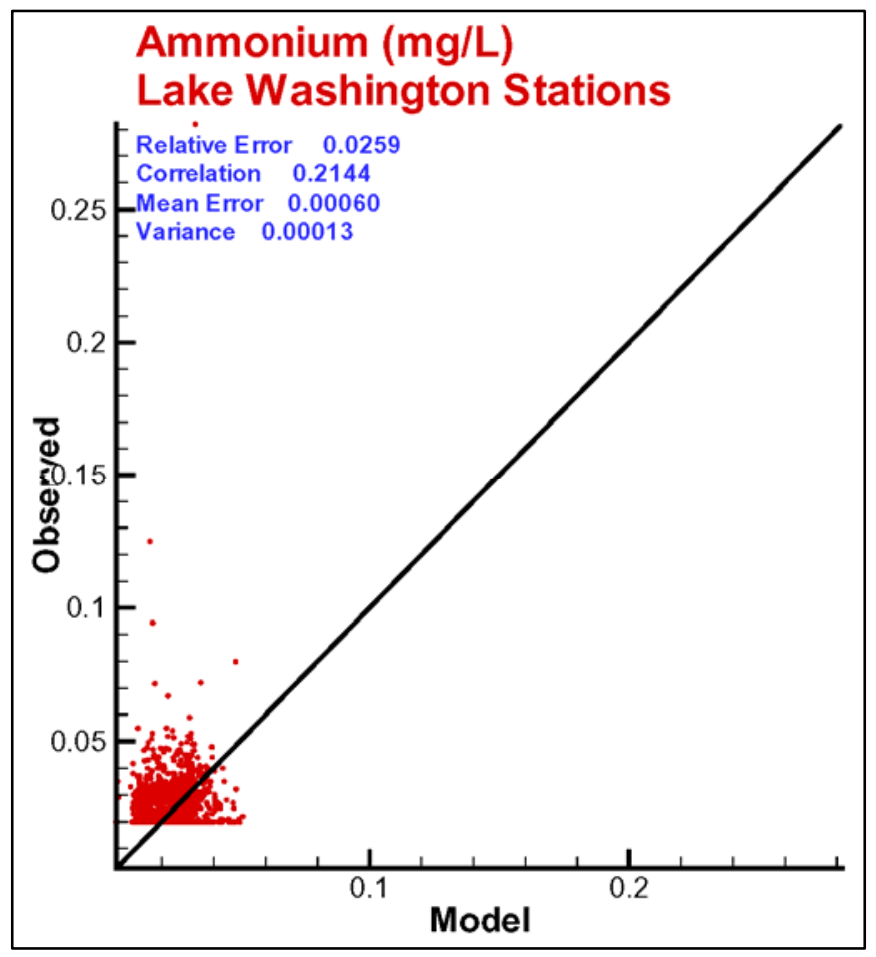

Figure 7-53. Scatterplot of observed and computed ammonium at Lake Washington stations 


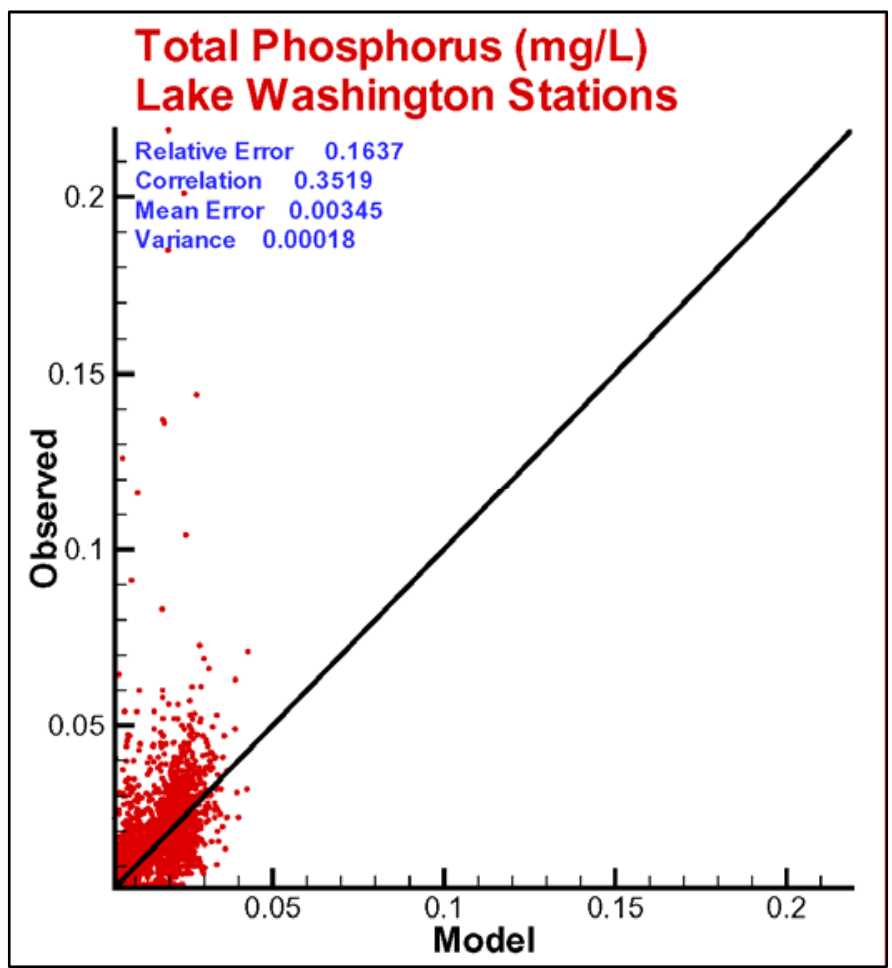

Figure 7-54. Scatterplot of observed and computed total phosphorus at Lake Washington stations

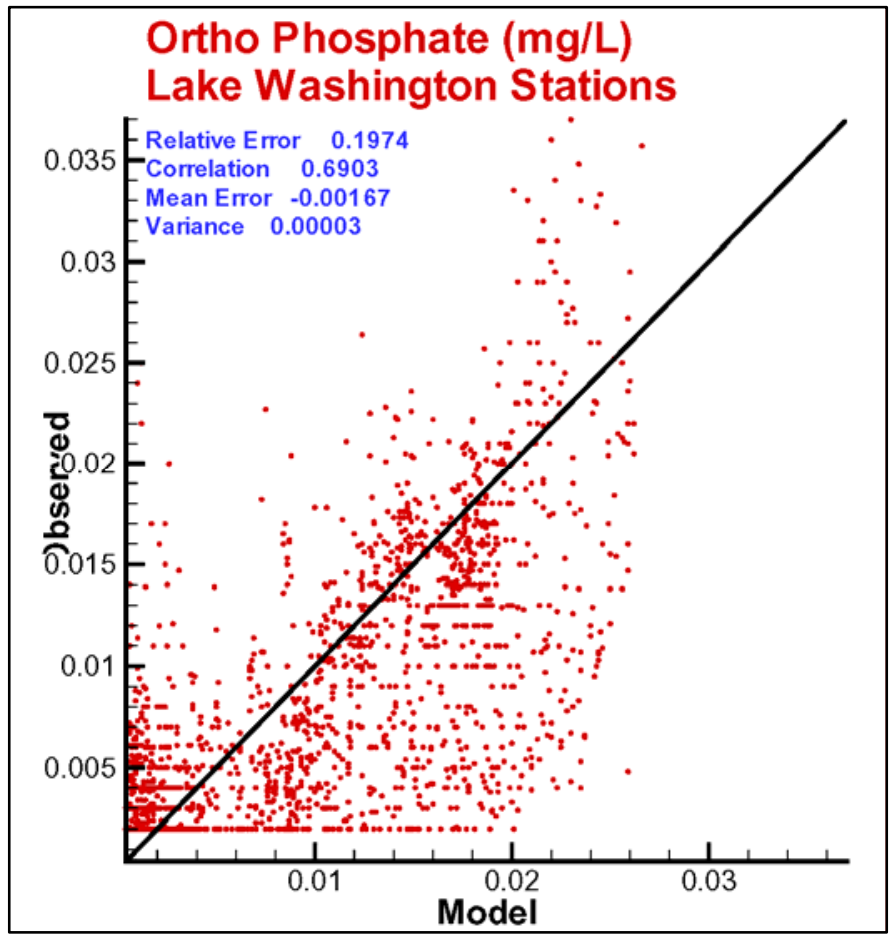

Figure 7-55. Scatterplot of observed and computed orthophosphorus at Lake Washington stations 


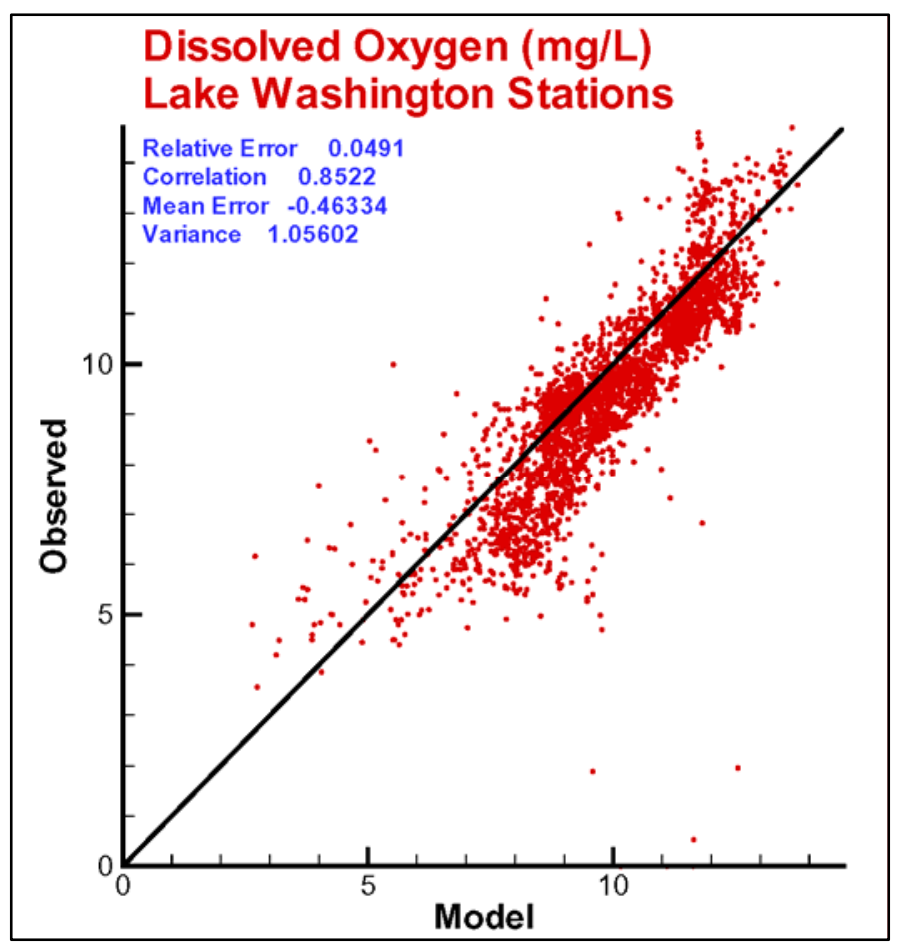

Figure 7-56. Scatterplot of observed and computed dissolved oxygen at Lake Washington stations

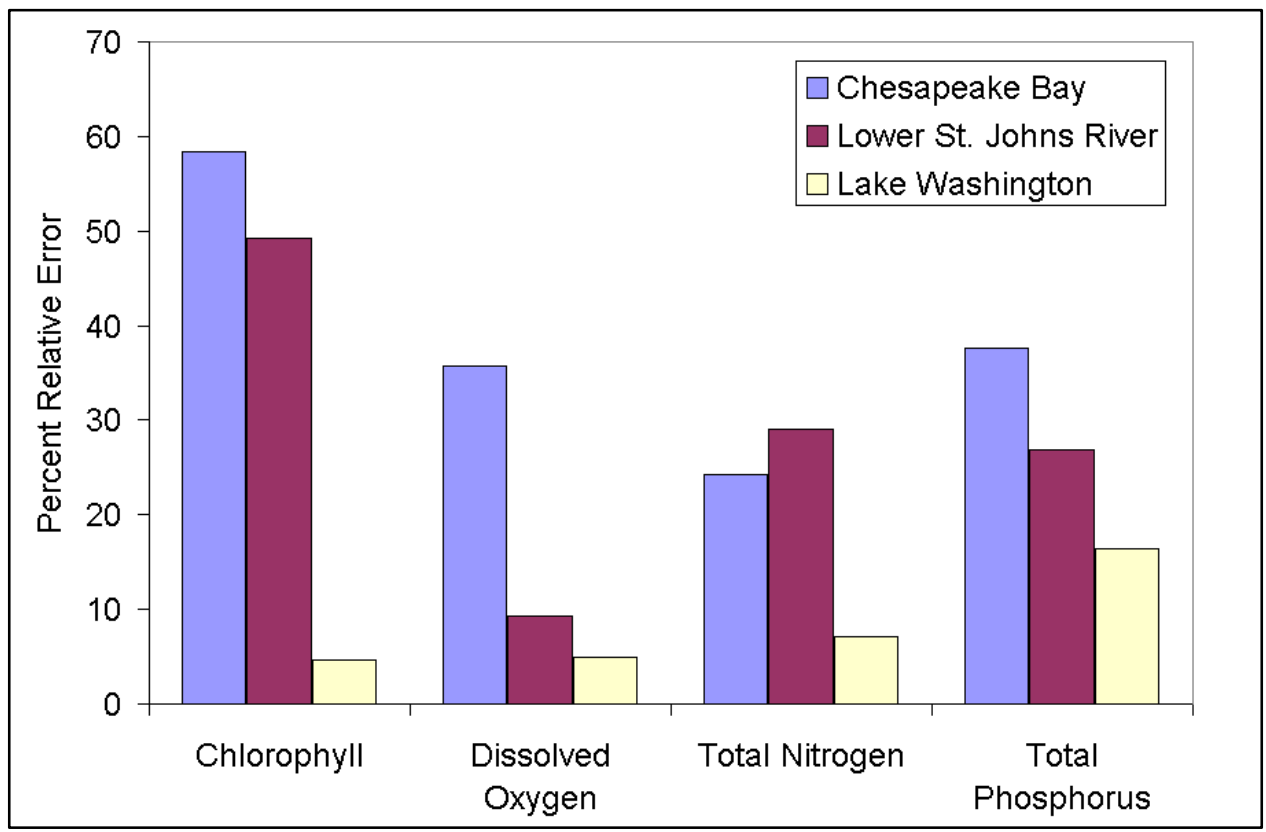

Figure 7-57. Relative error in three model applications 


\section{Process-based Verification}

\section{Introduction}

A rich database of process measurements exists for Lake Washington. These include measures of primary production, respiration, deposition, and sedimentwater fluxes. Extensive nutrient budgeting for the lake has also been conducted. None of these analyses corresponds with the model application period. Still, it is worthwhile to examine model performance in light of these measures and analyses. The majority of measures were conducted near present Station 852 (Figure 8-1). This is the deepest portion of the lake and is removed from major riverine inflows. Unless otherwise noted, model results are from the column of cells corresponding to Station 852.

\section{Primary Production}

Net primary production was measured during the mid-1970's (Devol and Packard 1978; Richey 1979) and again in 1980 (Quay et al. 1986). For comparison with the model, monthly-average values were computed from individual measures. Averages comprised as few as 2 (December) to as many as 13 observations (May). Observations indicate two peaks in production (Figure 82). The first occurs in April, concurrent with the spring phytoplankton bloom. The second, higher peak occurs in July when observed chlorophyll is much lower than the spring maximum. This pattern resembles that for estuaries, e.g., Chesapeake Bay, in which maximum biomass and maximum production are out of phase (Harding et al. 2002). The model indicates a system in which biomass and production are in phase. Peak production occurs concurrent with the spring bloom. Computed production corresponds well with observed mean values during the spring months but is closer to the observed minimum values otherwise. The mean annual observed net production is $\approx 0.46 \mathrm{~g} \mathrm{C} \mathrm{m}^{-2} \mathrm{day}^{-1}$ while the model production is $0.25 \mathrm{~g} \mathrm{C} \mathrm{m}^{-2}$ day $^{-1}$.

Considerable effort has been devoted to successfully modeling primary production in estuarine systems (Cerco and Noel in preparation). The estuarine model has two key differences from the Lake Washington application. The first is the use of a quadratic rather than linear phytoplankton predation term. The second is the distinction of spring and summer algal groups. An additional difference in the two efforts is the availability of an extensive, contemporary database of primary production observations for Chesapeake Bay. With some 
effort, the observed Lake Washington production pattern can be modeled. Complete confidence in modeled production requires, however, a comprehensive, consistent database of contemporary observations for comparison with the model.

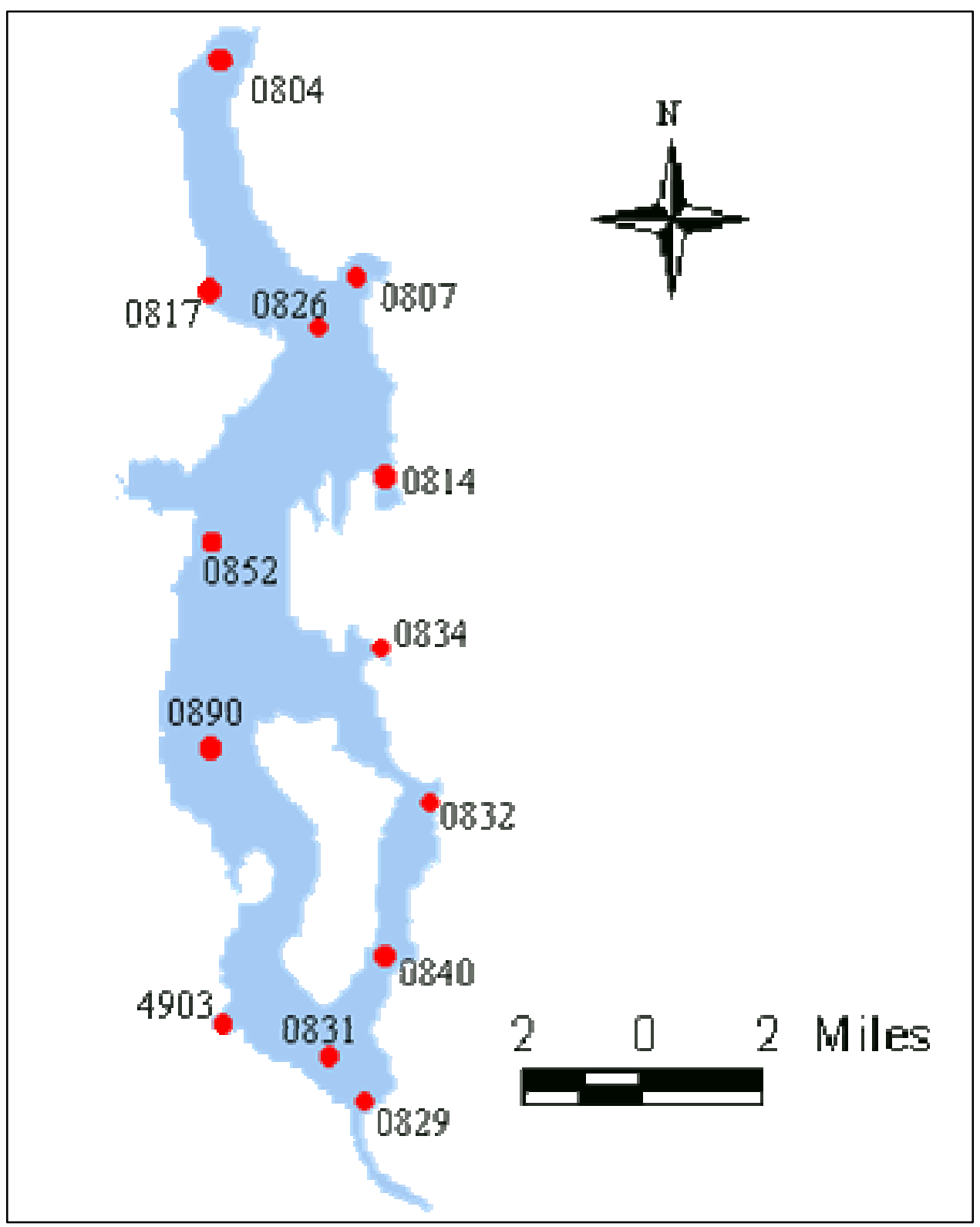

Figure 8-1. Lake Washington sample stations 


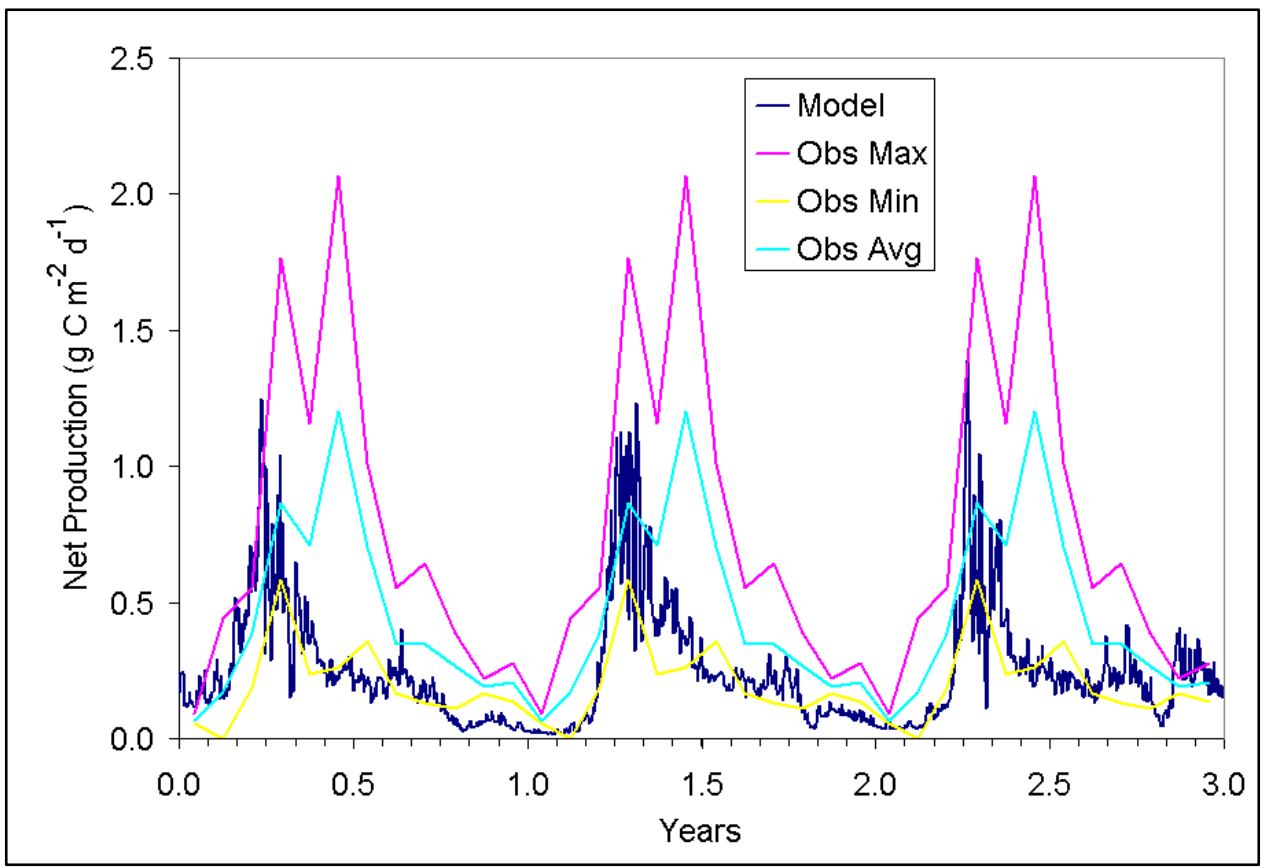

Figure 8-2. Observed and computed net primary production. Observations are monthly means of reported values. Daily modeled values are from Station 852

\section{Respiration}

Respiration was measured on six dates, at multiple depths, in 1980 (Quay et al. 1986). Observations near the surface (Figure 8-3) indicate highest respiration rates occur in June and July. Near the bottom, little seasonality is apparent (Figure 8-4), and average respiration is much less than at the surface (Figure 85). The model demonstrates remarkable correspondence with the majority of surface respiration measures. Near the bottom, computed respiration exceeds observed. Both model and observations indicate a surface-to-bottom gradient in respiration but the observations fall off much more rapidly, below $10 \mathrm{~m}$, than the model. 


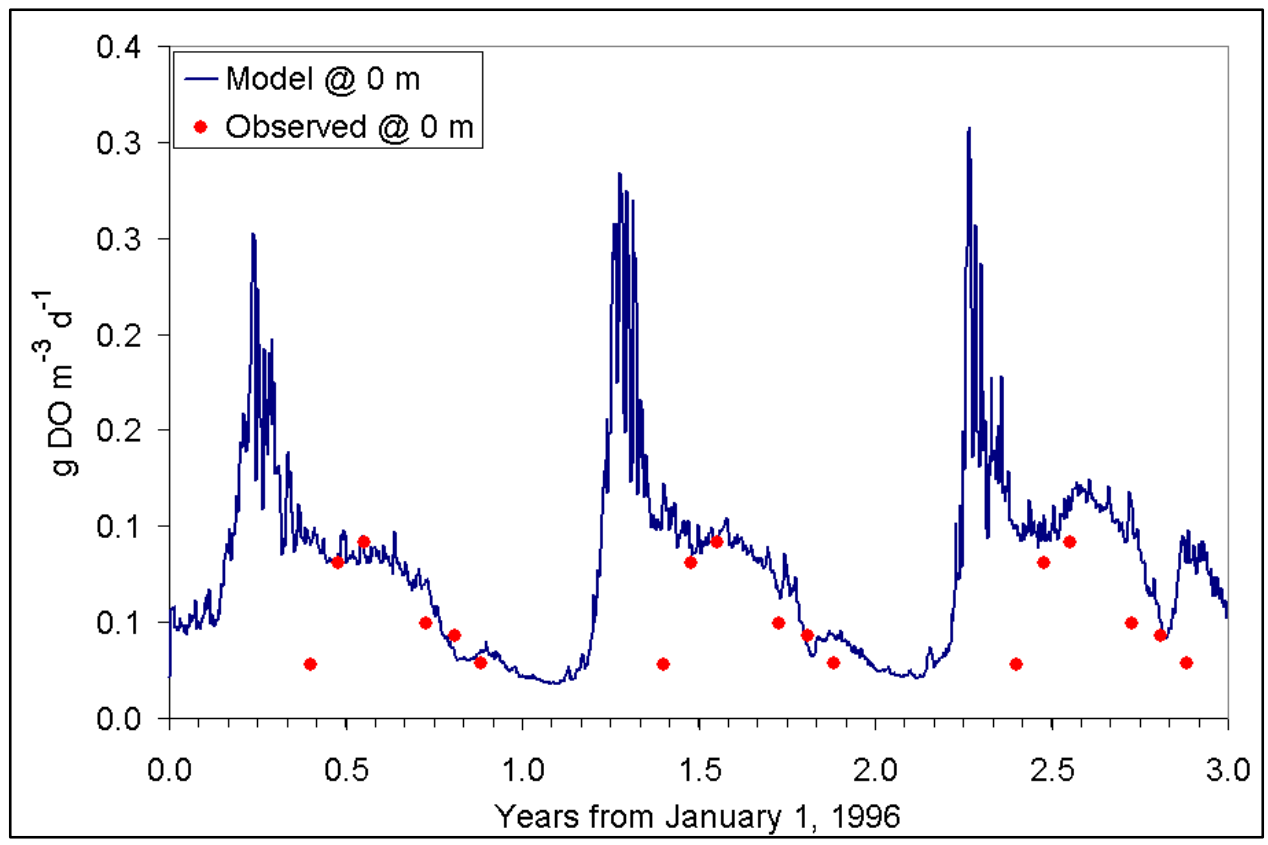

Figure 8-3. Observed and computed surface respiration

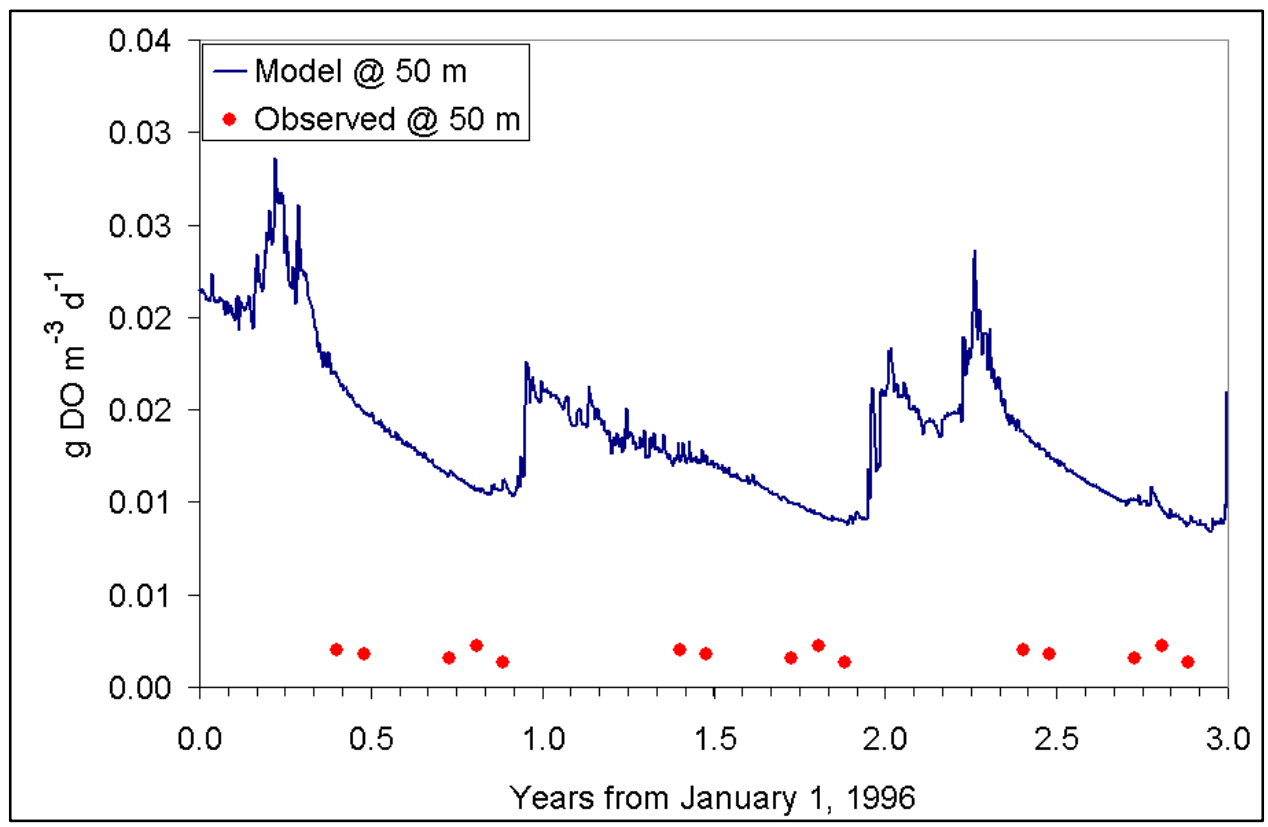

Figure 8-4. Observed and computed respiration at 50-m depth 


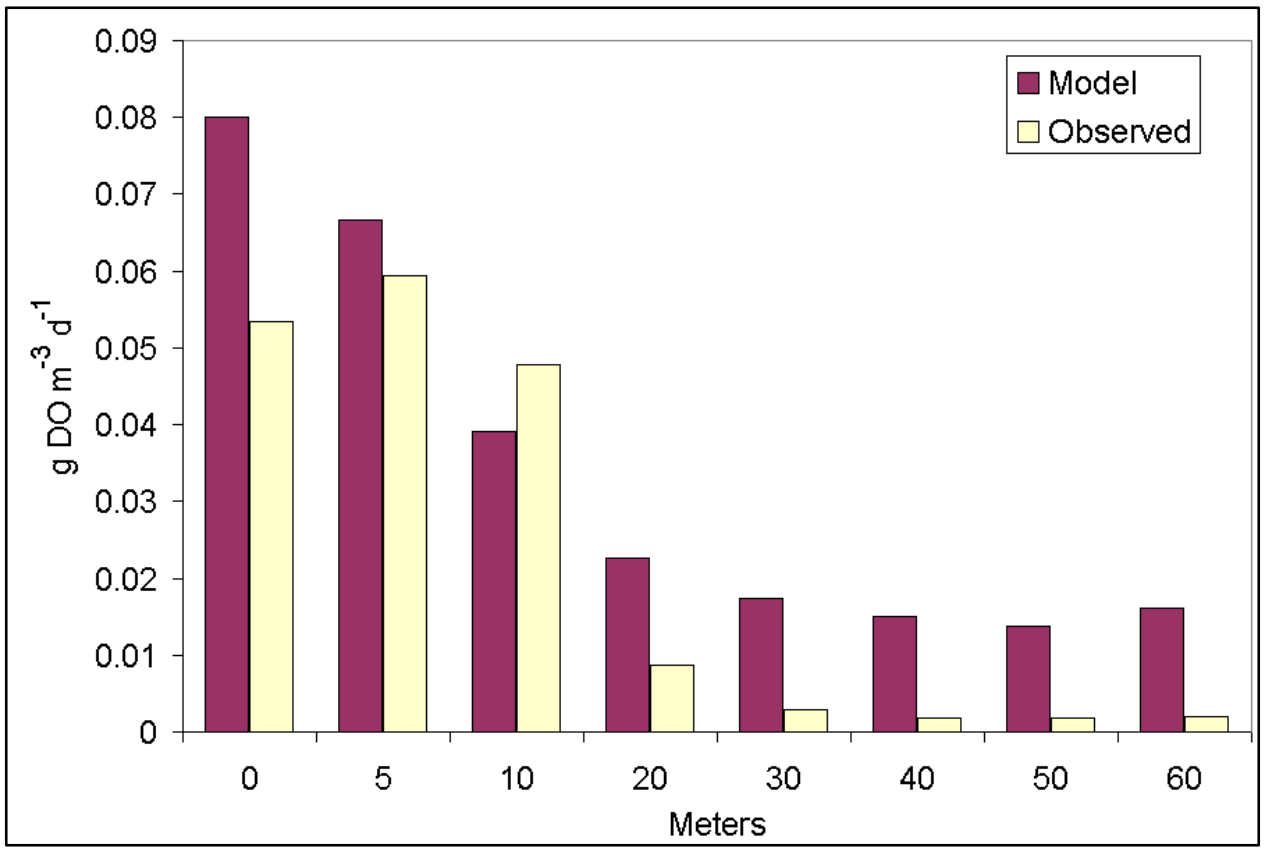

Figure 8-5. Mean observed and computed respiration at multiple depths

The observations indicate lower microbial activity at great depths than near the surface. The lower activity may be due partly to lower temperature near the bottom. Attempts to reproduce the observations by manipulating temperature coefficients in the model were not successful, however. It is suggested that the dissolved organic carbon found below the thermocline is more refractory than the dissolved organic carbon in surface waters. Two approaches can be adopted to improve representation of the vertical variation in respiration. The first is to differentiate labile and refractory dissolved organic carbon in the model. This approach requires substantial activity in coding and also requires a means to distinguish loads and boundary conditions for the multiple carbon forms. A second, more empirical, approach is to employ lower first-order dissolved organic carbon mineralization rates below the thermocline.

\section{Deposition and Sediment-Water Fluxes}

A set of observed deposition and sediment-water fluxes was assembled from multiple sources. These were converted to model units and reported in Table 8-1. 


\begin{tabular}{|c|c|c|c|}
\hline \multicolumn{4}{|c|}{$\begin{array}{l}\text { Table 8-1 } \\
\text { Observed Deposition and Sediment-Water Fluxes }\end{array}$} \\
\hline Quantity & Range & Comment & Source \\
\hline $\begin{array}{l}\text { Sediment oxygen demand, } \\
\mathrm{g} \mathrm{m}^{-2} \text { day }^{-1}\end{array}$ & $\begin{array}{l}0.05 \text { to } \\
0.11\end{array}$ & $\begin{array}{l}\text { Derived from diffusive } \\
\mathrm{CO}_{2} \text { flux }\end{array}$ & $\begin{array}{l}\text { Kuivila and Murray } \\
\text { (1984) }\end{array}$ \\
\hline $\begin{array}{l}\text { Sediment oxygen demand, } \\
\mathrm{g} \mathrm{m}^{-2} \text { day }^{-1}\end{array}$ & $\begin{array}{l}0.14 \text { to } \\
0.19\end{array}$ & $\begin{array}{l}\text { Measured oxygen } \\
\text { consumption }\end{array}$ & Kuivila et al. (1988) \\
\hline $\begin{array}{l}\text { Sediment } \mathrm{NH}_{4} \text { release, } \\
\mathrm{mg} \mathrm{N} \mathrm{m}^{-2} \text { day }^{-1}\end{array}$ & $\begin{array}{l}1.5 \text { to } \\
11.4\end{array}$ & Diffusive flux & $\begin{array}{l}\text { Kuivila and Murray } \\
\text { (1984) }\end{array}$ \\
\hline $\begin{array}{l}\text { Sediment } \mathrm{PO}_{4} \text { release, } \\
\mathrm{mg} \mathrm{P} \mathrm{m}^{-2} \text { day }^{-1}\end{array}$ & 1.3 & Derived from $\mathrm{P}$ budget & $\begin{array}{l}\text { Edmondson and } \\
\text { Lehman (1981) }\end{array}$ \\
\hline $\begin{array}{l}\text { Carbon deposition, } \\
\mathrm{g} \mathrm{C} \mathrm{m}^{-2} \text { day }^{-1}\end{array}$ & 0.15 & $\begin{array}{l}\text { Average rate near } \\
\text { bottom }\end{array}$ & $\begin{array}{l}\text { Kuivila and Murray } \\
\text { (1984) }\end{array}$ \\
\hline $\begin{array}{l}\text { Carbon deposition, } \\
\mathrm{g} \mathrm{C} \mathrm{m}^{-2} \text { day }^{-1}\end{array}$ & $\begin{array}{l}0.05 \text { to } \\
0.3\end{array}$ & Sediment trap at $50 \mathrm{~m}$ & Quay et al. (1986) \\
\hline $\begin{array}{l}\text { Nitrogen deposition, } \\
\mathrm{mg} \mathrm{N} \mathrm{m}^{-2} \text { day }^{-1}\end{array}$ & 8 to 33 & $\begin{array}{l}\text { Sediment traps at } \\
\text { various depths }\end{array}$ & $\begin{array}{l}\text { Edmondson and } \\
\text { Lehman (1981) }\end{array}$ \\
\hline 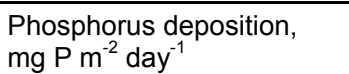 & 2 to 67 & $\begin{array}{l}\text { Sediment traps at } \\
\text { various depths }\end{array}$ & $\begin{array}{l}\text { Edmondson and } \\
\text { Lehman (1981) }\end{array}$ \\
\hline
\end{tabular}

The model demonstrates a system in which maximum carbon deposition occurs in June and July (Figure 8-6). The deposition peak is sharp and lags by several months the peak in net production. The model behavior suggests the maximum deposition is a result of the high first-order phytoplankton predation term employed in summer. Model deposition represents, in effect, deposition of zooplankton fecal matter. The peak modeled deposition exceeds deposition rates measured in particle traps, but the model mean, $0.26 \mathrm{~g} \mathrm{C} \mathrm{m}^{-2}$ day $^{-1}$, is characteristic of observed deposition rates. Model sediment oxygen demand occupies a range from 0.2 to $0.4 \mathrm{~g} \mathrm{~m}^{-2} \mathrm{day}^{-1}$. Modeled demand is at the upper range of observed demand. Most of the observations were collected in colder months (February-April and October) during which temperature effects would be expected to diminish sediment oxygen demand. In view of the sporadic nature of the observations, it is believed that the differences between computed and observed sediment oxygen demand are insignificant.

Modeled nitrogen deposition follows the pattern of carbon deposition (Figure 8-7). As with carbon, peak modeled deposition exceeds observed, but the mean modeled rate, $31 \mathrm{mg} \mathrm{N} \mathrm{m}^{-2} \mathrm{day}^{-1}$, is representative of the observations. Modeled sediment ammonium release reflects very well the observed values. A novel result from the model is the indication that sediment nitrate uptake is a substantial component of the sediment-water dissolved nitrogen flux. No observations exist to verify the model results, but the computed values are expected and reasonable based on observations conducted in estuaries and tidal fresh water (DiToro 2001). 


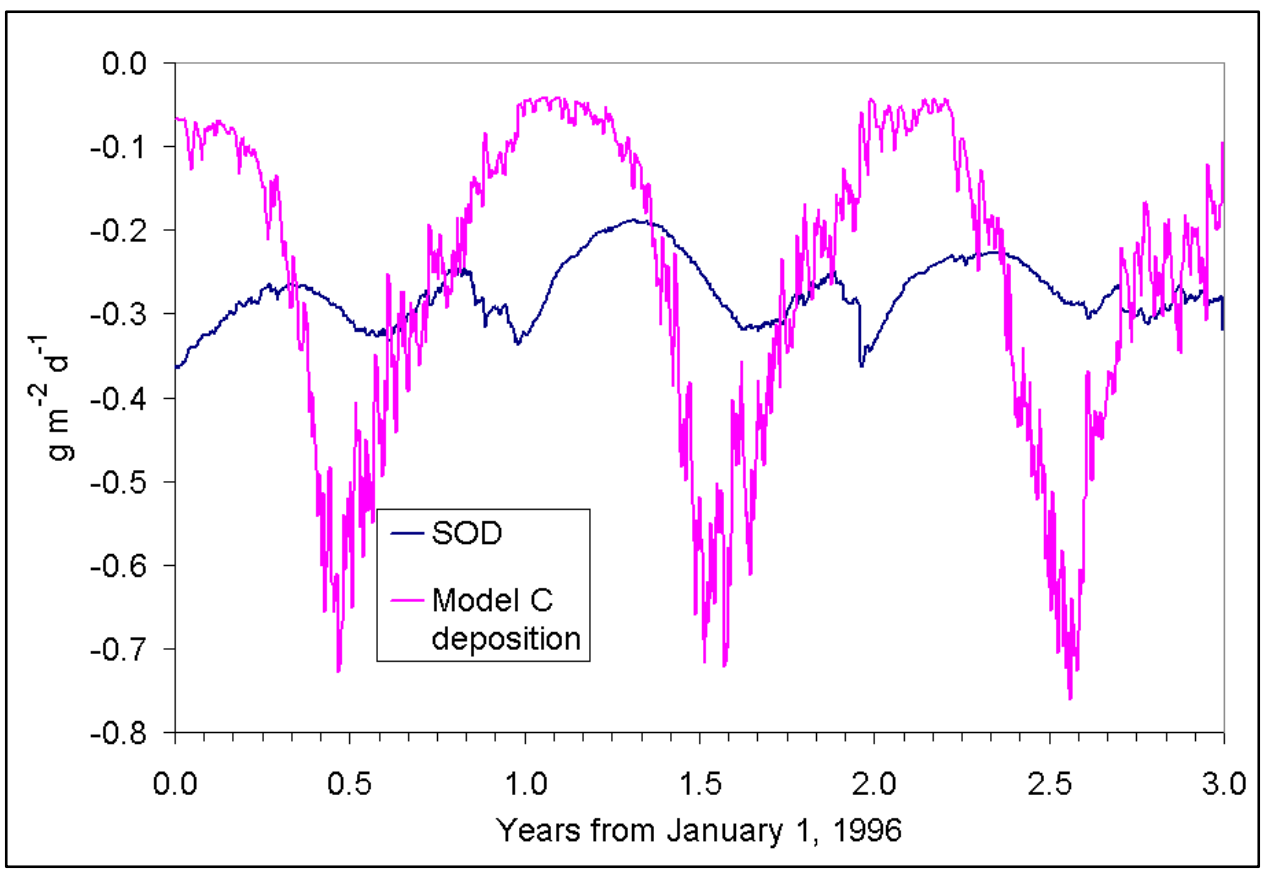

Figure 8-6. Computed carbon deposition and sediment oxygen demand at Station 852

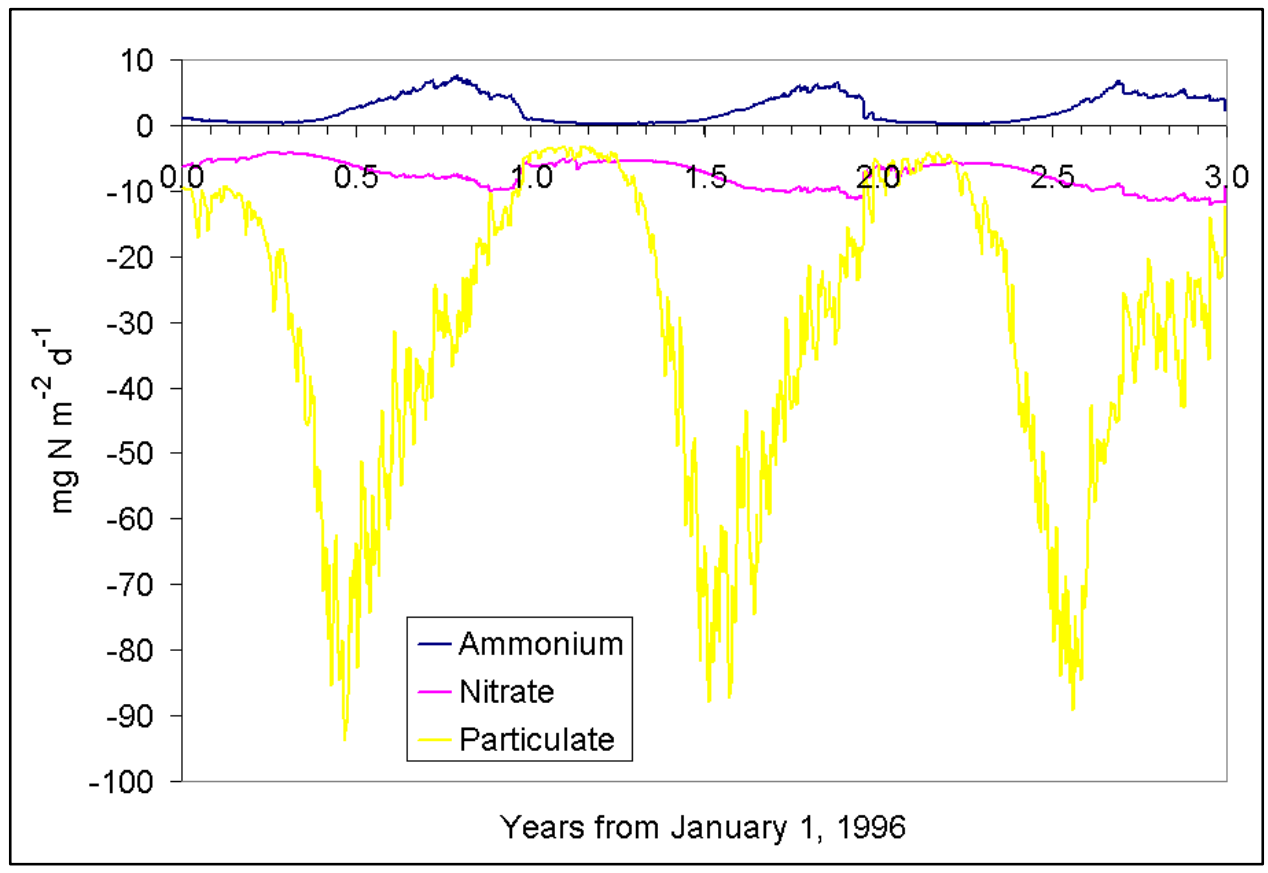

Figure 8-7. Computed particulate and dissolved sediment-water nitrogen flux at Station 852

In contrast to carbon and nitrogen, peak modeled phosphorus deposition (Figure 8-8) is less than peak observed. The modeled deposition is well within the observed range. Computed phosphorus flux is usually representative of the observed flux. Larger spikes are occasionally computed by the model. These 
occur when computed dissolved oxygen concentration dips below the value used in the sediment model, $2 \mathrm{~g} \mathrm{~m}^{-3}$, to initiate transformation to anoxic conditions. The model is believed to successfully represent phosphorus deposition and sediment release in Lake Washington.

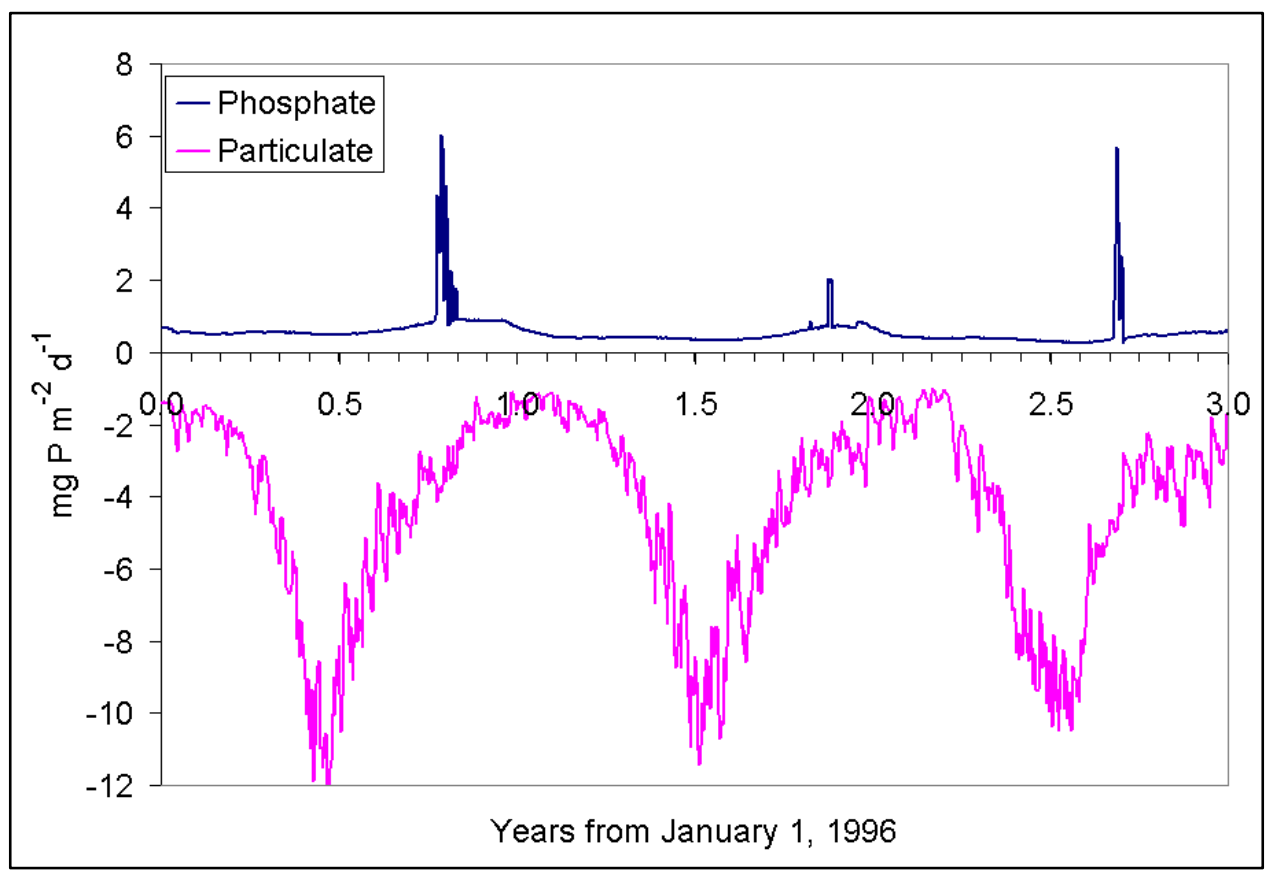

Figure 8-8. Computed particulate and dissolved sediment-water phosphorus flux at Station 852

\section{System Nutrient Budgets}

Systemwide budgets were constructed for nitrogen (Figure 8-9) and phosphorus (Figure 8-10) in Lake Washington (Lake Union was not considered). Computed sources and sinks for three years were averaged into monthly values.

The budgets indicate a system in which largest nutrient loads occur from November through March. These loads are balanced by outflow through Lake Union and by net accumulation in the water column. Peak nitrogen deposition to the sediments occurs from May through July. The nitrogen deposition is balanced by a decrease in water column mass. Dissolved nitrogen flux is into the sediments and is a small part of the total budget. The net dissolved nitrogen flux into the sediments is the result of sediment nitrate uptake that exceeds sediment ammonium release. Peak phosphorus deposition to the sediments occurs from April to July. This deposition is balanced by recycling of dissolved phosphorus from sediments to water and by a decrease in water column mass. 


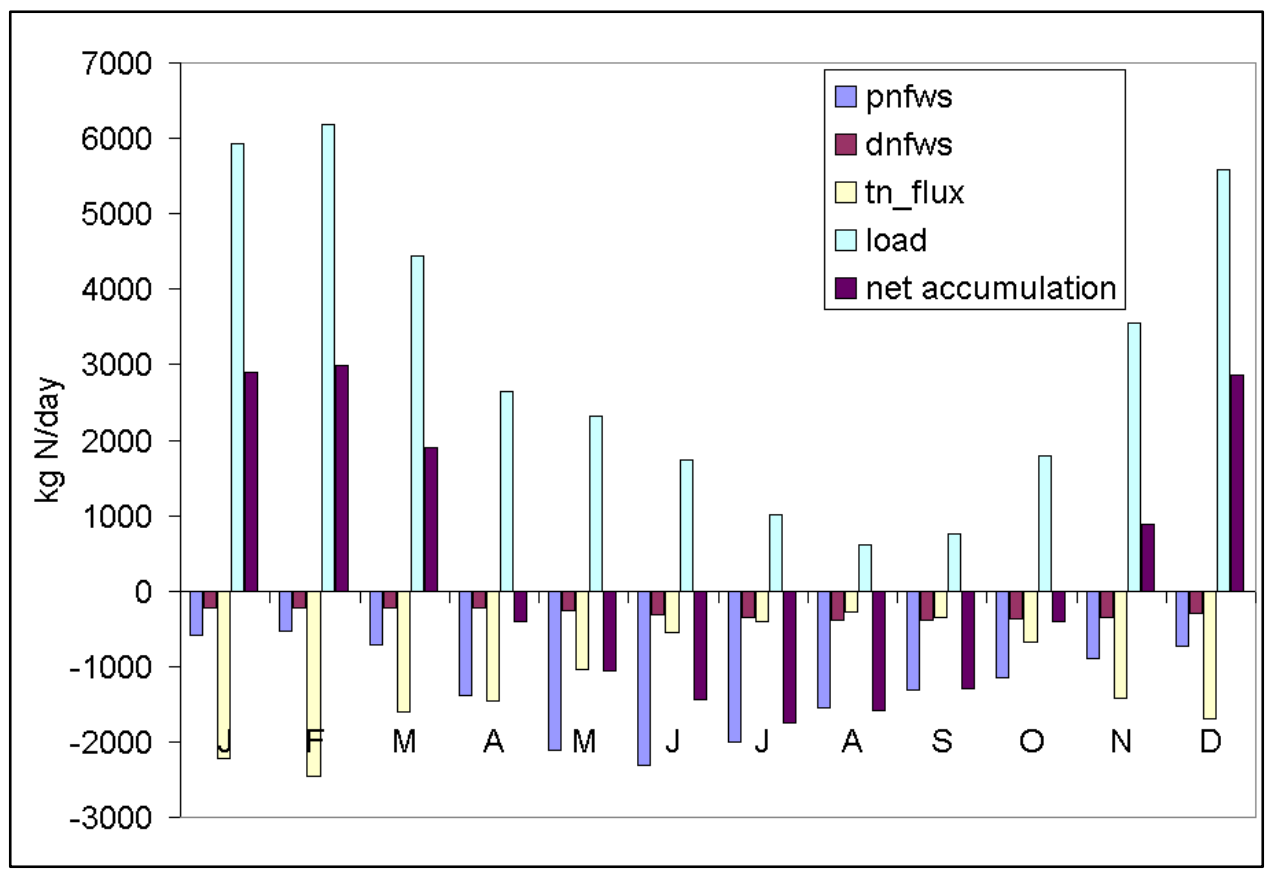

Figure 8-9. Lake Washington model nitrogen budget. Positive fluxes are to the Lake Washington water column. pnfws = particulate nitrogen flux from water to sediment; dnfws = dissolved nitrogen flux at sediment-water interface; tn_flux = transport at Lake Union interface; load = sum of all external loads; and net accumulation = change in water column mass

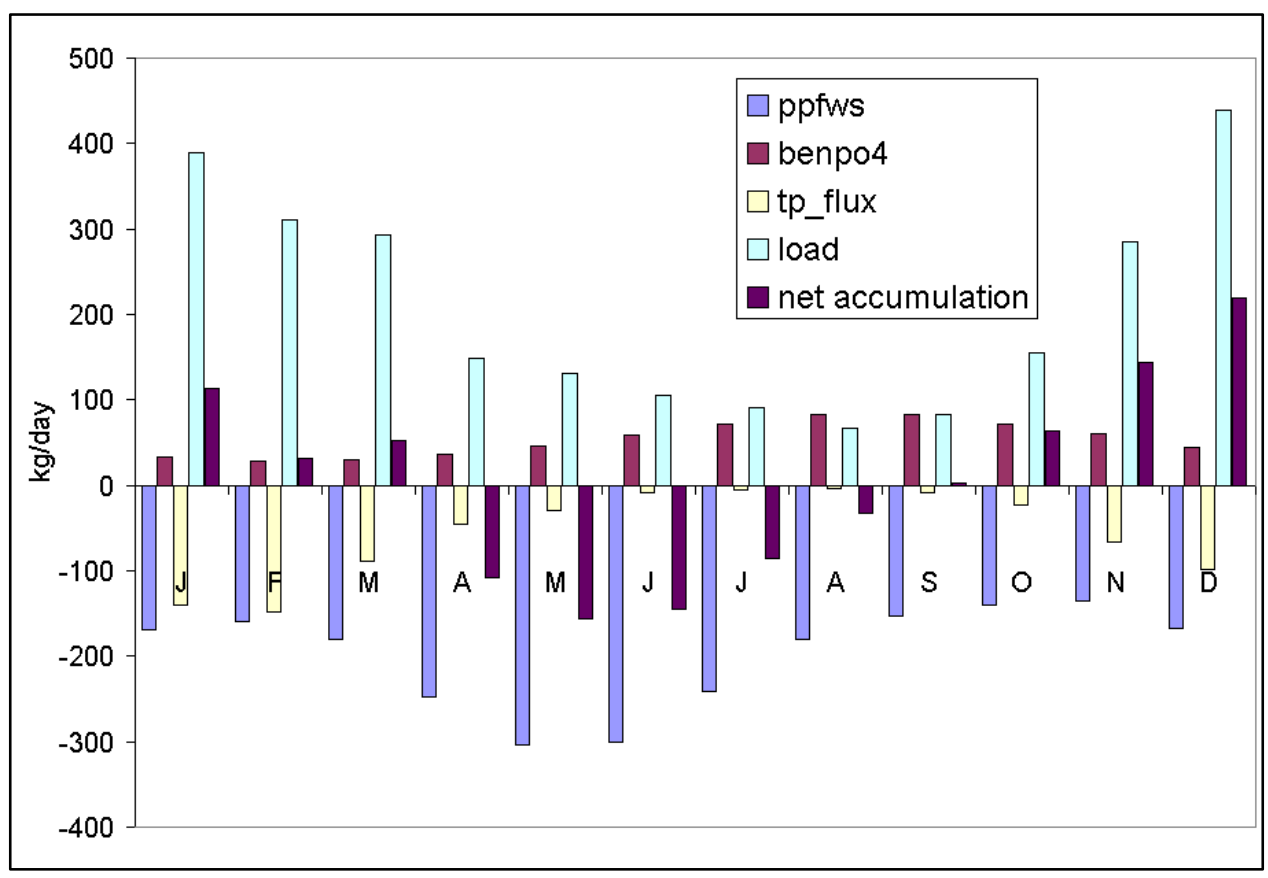

Figure 8-10. Lake Washington model phosphorus budget. Positive fluxes are to the Lake Washington water column. ppfws $=$ particulate phosphorus flux from water to sediment; benpo4 = dissolved phosphorus flux at sediment-water interface; tp_flux = transport at Lake Union interface; load = sum of all external loads; and net accumulation = change in water column mass 
On an annual basis, the Sammamish River is computed as the largest source of nutrients to Lake Washington, followed by the Cedar River and other distributed sources (Table 8-2). The majority of the nutrient load is deposited in the sediments. A lesser amount leaves via Lake Union. The authors compared their budget to the average of three most recent years, 1976-1978, reported by Edmondson and Lehman (1981) (Table 8-3). The nutrient loads of the present study are 30 percent (nitrogen) to 60 percent (phosphorus) higher than the loads from the late 1970's. To some extent, the higher loads can be attributed to higher flows. Mean hydrologic loading reported by Edmondson and Lehman for 19761978 was $33 \mathrm{~m}^{3} \mathrm{~s}^{-1}$ versus $39 \mathrm{~m}^{3} \mathrm{~s}^{-1}$ for this study. The 18 percent higher flows during this study do not completely account for the higher loads. It cannot be said with certainty whether the remaining disparity indicates a loading trend in the lake or differences in computational methods. Both this model and Edmondson and Lehman indicate half the fluvial nitrogen load is deposited in the sediments. Since the model load is larger, the model deposition exceeds the Edmondson and Lehman budget. Both budgets also show close correspondence in the fraction of fluvial phosphorus load, $\approx 80$ percent deposited in the sediments. As with nitrogen, the larger phosphorus load of this study produces a larger net load to the sediments. Overall, it is concluded that the nutrient budget of this study provides excellent correspondence with the independent calculations of Edmondson and Lehman.

\begin{tabular}{|c|c|c|}
\hline \multicolumn{3}{|c|}{$\begin{array}{l}\text { Table 8-2 } \\
\text { Model Nutrient Budget, kg day }{ }^{-1}\end{array}$} \\
\hline Source & Nitrogen & Phosphorus \\
\hline Cedar & 861 & 63.5 \\
\hline Sammamish & 1251 & 75.9 \\
\hline Thornton & 55 & 3.4 \\
\hline Distributed & 756 & 38.3 \\
\hline CSO & 16 & 2.3 \\
\hline Atmospheric & 95 & 24.7 \\
\hline Particle Flux & -1271 & -198.2 \\
\hline Dissolved Flux & -300 & 53.8 \\
\hline Outflow & \begin{tabular}{|l|}
-1177 \\
\end{tabular} & -55.6 \\
\hline
\end{tabular}

\begin{tabular}{|c|c|c|c|c|}
\hline \multicolumn{5}{|c|}{$\begin{array}{l}\text { Table 8-3 } \\
\text { Model Nutrient Budget Compared to Edmondson and Lehman } \\
\text { (1981) }\end{array}$} \\
\hline \multirow[b]{2}{*}{ Source } & \multicolumn{2}{|c|}{ Nitrogen, kg day ${ }^{-1}$} & \multicolumn{2}{|c|}{ Phosphorus, kg day ${ }^{-1}$} \\
\hline & Model & $E \& L$ & Model & E\&L \\
\hline Fluvial & 2938 & 2249 & 183 & 115 \\
\hline Atmospheric & 95 & 89 & 25 & 23 \\
\hline Outflow & 1177 & 1149 & 56 & 47 \\
\hline Net Input & 1571 & 1190 & 144 & 92 \\
\hline
\end{tabular}




\section{References}

Cerco, C., and Noel, M. "The 2002 Chesapeake Bay eutrophication model" (in preparation), U.S. Army Engineer Research and Development Center, Vicksburg, MS.

Devol, A., and Packard, T. (1978). "Seasonal changes in respiratory enzyme activity and productivity in Lake Washington microplankton," Limnology and Oceanography 23(1), 104-111.

DiToro, D. (2001). Sediment flux modeling John Wiley, New York.

Edmondson, W., and Lehman, J. (1981). "The effect of changes in the nutrient income on the condition of Lake Washington," Limnology and Oceanography 26(1), 1-29.

Harding, L., Mallonee, M., and Perry, E. (2002). "Toward a predictive understanding of primary productivity in a temperate, partially stratified estuary," Estuarine, Coastal, and Shelf Science 55, 437-463.

Kuivila, K., and Murray, J. (1984). “Organic matter diagenesis in freshwater sediments: The alkalinity and total $\mathrm{CO}_{2}$ balance and methane production in the sediments of Lake Washington," Limnology and Oceanography 29(6), 1218-1230.

Kuivila, K., Murray, J., Devol, A., Lidstrom, M., and Reimers, C. (1988). "Methane cycling in the sediments of Lake Washington," Limnology and Oceanography 33(4, part 1), 571-581.

Richey, J. (1979). "Patterns of phosphorus supply and utilization in Lake Washington and Findley Lake," Limnology and Oceanography 24(5), 906916.

Quay, P., Emerson, S., Quay, B., and Devol, A. (1986). "The carbon cycle for Lake Washington - A stable isotope study," Limnology and Oceanography 31(3), 596-611. 


\section{Summary, Conclusions, Recommendations}

\section{Introduction}

In September 2000, the King County Department of Natural Resources and Parks, Washington State, signed a cooperative agreement with the U.S. Army Engineer Research and Development Center (ERDC) to provide the water quality models necessary for the Sammamish-Washington Analysis Program. ERDC responsibilities under the agreement included the following:

1. Configure and execute a model for Lake Washington.

2. Submit written project reports.

3. Provide training and expertise to county personnel.

4. Assist in assessing model operation, interpretation of field data, and model results.

5. Modify code as required.

6. Provide expertise on lake and river dynamics such as nutrient dynamics, ecology, and sediment-water interactions.

For the modeling effort, ERDC applied the CH3D-WES hydrodynamic model and the CE-QUAL-ICM eutrophication model. The models were applied to Lakes Washington and Union for the period 1995-1997. Emphasis was on Lake Washington. Lake Union was modeled so that the downstream boundary condition could be located away from the region of greatest interest. This report presents the primary documentation of the model effort.

\section{Flows, Loads, Boundary Conditions}

Flows into Lake Washington may be divided into two categories: gauged and distributed. Gauged flows include the Sammamish River, the Cedar River, and Thornton Creek. The distributed flows enter at undefined locations and are not monitored. These were computed by the sponsor based on precipitation and basin characteristics. Daily, gauged flows were input to the model at corresponding locations. The distributed flows were pooled into 10 locations that could be identified as named tributaries or features and input to the model on a daily basis. 
For the study period, the Cedar River provided 60 percent of the runoff followed by the Sammamish River with 28 percent. Thornton Creek provided $\approx 1$ percent. Distributed flows contributed the remaining 11 percent.

Daily runoff loads were computed as the product of flow and concentration. Concentrations in gauged flows, observed at approximately monthly intervals, were provided by the sponsor. Linear interpolation was used to create daily concentrations from the monthly values. Combined-sewer overflows (CSOs), sanitary-sewer overflows, and spills were reported at 28 locations. Daily flow volume for each incident was provided by the sponsor. The sponsor also provided characteristic concentrations for the discharges. Daily loads were computed as the product of flow and concentration and input to the model at appropriate locations. Annual atmospheric loads were obtained from Edmondson and Lehman (1981) and converted to daily loads for input to the model.

The Sammamish River was the predominant nutrient source even though flow was higher in the Cedar. The Sammamish contributed greater loads because this river was nutrient-enriched relative to the Cedar. Nutrient concentrations in distributed loads, as exemplified by Thornton Creek, were enriched relative to both large rivers. Although CSO events contributed enormous loads over short periods, these sources were minor compared with runoff on an annual basis. Likewise, atmospheric deposition was a minor component of the annual nutrient budget.

On an annual basis, major fecal coliform loads were from the Sammamish and Cedar, followed by distributed loads. CSO loads included several events that rivaled loads from major runoff sources, but spills and overflows were minor sources on a long-term basis.

Suspended solids concentrations in the Cedar exceeded the Sammamish so that the Cedar was the dominant source to the system. Distributed sources were enriched with solids relative to major runoff sources, but the role of distributed solids sources was less than distributed nutrient sources. Sewer overflows and spills were a minor component of the long-term suspended solids budget.

\section{Water Quality Model Formulation}

The CE-QUAL-ICM water quality model was applied to Lake Washington. The foundation of CE-QUAL-ICM is the solution to the three-dimensional massconservation equation for a control volume. Control volumes correspond to cells on the model grid. As applied to Lake Washington, the CE-QUAL-ICM model incorporated 20 state variables in the water column including physical variables, phytoplankton, multiple forms of carbon, nitrogen, and phosphorus, a pathogen, and two toxicants (Table 9-1). The pathogen and toxicants were added specifically for the Lake Washington application. 


\begin{tabular}{|c|c|}
\hline \multicolumn{2}{|c|}{$\begin{array}{l}\text { Table } 9-1 \\
\text { Lake Washington Water Quality Model State Variables }\end{array}$} \\
\hline Temperature & Fixed Solids \\
\hline Phytoplankton & Fecal Coliform \\
\hline Dissolved Organic Carbon & Labile Particulate Organic Carbon \\
\hline Refractory Particulate Organic Carbon & Ammonium \\
\hline Nitrate+Nitrite & Dissolved Organic Nitrogen \\
\hline Labile Particulate Organic Nitrogen & Refractory Particulate Organic Nitrogen \\
\hline Total Phosphate & Dissolved Organic Phosphorus \\
\hline Labile Particulate Organic Phosphorus & Refractory Particulate Organic Phosphorus \\
\hline Chemical Oxygen Demand & Dissolved Oxygen \\
\hline Toxicant One & Toxicant Two \\
\hline
\end{tabular}

\section{Modeling Processes at the Sediment-Water Interface}

The predictive benthic sediment model applied to Lake Washington was first developed for use in Chesapeake Bay (DiToro 2001). The model (Table 9-2) is driven by net settling of organic matter from the water column to the sediments. In the sediments, the model simulates the diagenesis (decay) of the organic matter. Diagenesis produces oxygen demand and inorganic nutrients. Oxygen demand, as sulfide (in salt water) or methane (in fresh water), takes three paths out of the sediments: export to the water column as chemical oxygen demand, oxidation at the sediment-water interface as sediment oxygen demand, or burial to deep, inactive sediments. Inorganic nutrients produced by diagenesis take two paths out of the sediments: release to the water column or burial to deep, inactive sediments.

\begin{tabular}{||l|l||}
\hline \multicolumn{2}{||l||}{$\begin{array}{l}\text { Table 9-2 } \\
\text { Sediment Model State Variables and Fluxes }\end{array}$} \\
\hline \hline State Variable & Sediment-Water Flux \\
\hline \hline Temperature & \\
\hline Particulate Organic Carbon & Sediment Oxygen Demand \\
\hline Sulfide/Methane & Release of Chemical Oxygen Demand \\
\hline Particulate Organic Nitrogen & \\
\hline Ammonium & Ammonium Flux \\
\hline Nitrate & Nitrate Flux \\
\hline Particulate Organic Phosphorus & \\
\hline Phosphate & Phosphate Flux \\
\hline
\end{tabular}

\section{Coupling with the Hydrodynamic Model}

Transport processes were modeled by a three-dimensional hydrodynamic model that operated independently of the water quality model (Johnson et al. 
2003). Transport information from the hydrodynamic model was processed and stored on-line for subsequent use by the water quality model. Computed flows, surface elevations, and vertical diffusivities were output at 1-hour intervals for use in the water quality model. The algorithms and codes for linking the hydrodynamic and water quality models were developed over a decade ago and have been tested and proved in extensive applications since then. For this application, linkage was verified through comparison of temperatures computed by the two models. A total of 3,468 comparisons of temperatures computed at 18 stations over a 3-year period were made. Correspondence between the two models was excellent. The linear correlation coefficient of the independently computed temperatures was $\approx 0.99$ and relative error was less than 1 percent.

A great deal of difficulty was encountered specifying hydrodynamic boundary conditions at the lock and dam on the lower end of Lake Union. After much trial and error, outflow was specified based on volume conservation. This specification was sufficient for the Lake Washington application. Modeling of Lake Union will require much more attention to flow and salinity exchange at the structure. Both the structure itself and the operation of the lock will have to be considered. Modeling of salinity intrusion and, consequently, circulation in Lake Union will be impossible without improvement in boundary condition specification. One recent study (Johnson et al. 2004) may provide some insight into the problem. The challenge of modeling this boundary should not be underestimated.

\section{Observation-based Calibration}

The primary database for calibration of the model was derived from a monitoring program conducted by King County Department of Parks and Natural Resources. The model was compared to observed temperature, dissolved oxygen, ammonium, nitrate+nitrite, total nitrogen, ortho-phosphorus, total phosphorus, chlorophyll, disk visibility, and fecal coliform. Comparisons were produced in a variety of graphical and statistical formats. Graphical formats included examination of time series, vertical profiles, and scatterplots. Statistics computed included mean error, relative error, and variance.

Overall, the model provided excellent representation of the annual cycle of temperature, chlorophyll, nutrients, and dissolved oxygen in the lake. The vertical structure was also well-represented. In relative terms, the greatest disparities between computations and observations were for ortho-phosphorus and total phosphorus. Least relative error was for ammonium, followed by chlorophyll and dissolved oxygen, which had nearly equivalent relative error. Relative error in the Lake Washington application compared most favorably with several alternate model applications.

One problem area in the model application was the trapping of excess orthophosphorus below the thermocline from late spring through fall turnover. The computation of excess ortho-phosphorus has been experienced in alternate model applications. The excess is believed to originate in the lack of bacterial phosphorus uptake in the model. It is not known that any models presently 
include this process. Mechanistic modeling of bacterial activity is probably unwarranted, but some empirical representation of bacterial uptake is possible and should be attempted. The sponsor has suggested that binding of phosphorus in zooplankton fecal pellets, and subsequent rapid sinking of these pellets, is not represented in the present model. Phosphorus removal via sinking may remove phosphorus that is presently being mineralized and causing an excess. This possibility is worth examining. Since ortho-phosphorus is well-represented in surface waters of the lake, where utilization as an algal nutrient is important, the computed excess of ortho-phosphorus does not compromise the utility of the model. However, the problem should be addressed.

Fecal coliform bacteria are indicators of pollution from human and/or animal waste. This study identifies the sources of coliform pollution and computes concentrations consistent with observations. The highest observed values are not represented in the model. The computations are affected by the crude loading information; e.g., all CSO events are characterized by a single concentration. Improved calculations of fecal coliform will require improved loading estimates.

The measure of light attenuation available for this study was disk visibility, also known as Secchi depth. The corresponding model variable is diffuse light attenuation. Attenuation can be related to disk visibility through an empirical relationship. The model properly represents the magnitude of disk visibility and the processes that contribute to seasonal variations in this observed quantity. The observations show a great deal of scatter about the model value and a great deal of scatter in general. The loose agreement between model and observed visibility is attributed to three factors: the inherent uncertainty in the disk visibility measure, lack of solids data for calibration of this attenuating factor, and the conversion from attenuation to disk visibility. Consideration should be given to replacement of the disk visibility measure with direct measurement of subsurface irradiance, from which attenuation can be readily calculated. The sponsor should consider measurement of color and turbidity and the relationship of these to attenuation. The present model uses an additive formula that computes attenuation as a function of background attenuation, suspended solids, and chlorophyll. If sufficient observations become available, consideration should be given to application of an optical model based on absorption and scattering (e.g., Gallegos et al. 1990).

\section{Process-based Verification}

A rich database of process measurements exists for Lake Washington. These include measures of primary production, respiration, deposition, and sedimentwater fluxes. Extensive nutrient budgeting for the lake has also been conducted. Although none of these analyses corresponds with the model application period, examination of model performance in light of these measures and analyses was thought worthwhile.

Observations indicate two peaks in net primary production. The first occurs in April, concurrent with the spring phytoplankton bloom. The second, higher peak occurs in July when observed chlorophyll is much lower than the spring 
maximum. This pattern resembles estuaries, e.g., Chesapeake Bay, in which maximum biomass and maximum production are out of phase. The model indicates a system in which biomass and production are in phase. Peak production occurs concurrent with the spring bloom. Computed production corresponds well with observed mean values during the spring months but is closer to the observed minimum values otherwise. The mean annual observed net production is $\approx 0.46 \mathrm{~g} \mathrm{C} \mathrm{m}^{-2}$ day $^{-1}$ while the model production is $0.25 \mathrm{~g} \mathrm{C} \mathrm{m}^{-2}$ day $^{-1}$.

Observations near the surface indicate highest respiration rates occur in June and July. Near the bottom, little seasonality is apparent and average respiration is much less than at the surface. The model demonstrates remarkable correspondence with the majority of surface respiration measures. Both model and observations indicate a surface-to-bottom gradient in respiration, but the observations fall off much more rapidly, below $10 \mathrm{~m}$, than the model.

Modeled particulate carbon, nitrogen, and phosphorus deposition to the bottom sediments are characteristic of rates observed in sediment traps. Modeled sediment oxygen demand is at the upper range of observed demand. Most of the observations were collected in colder months during which temperature effects diminish sediment oxygen demand. In view of the sporadic nature of the observations, the differences between computed and observed sediment oxygen demand are believed to be insignificant. Modeled sediment ammonium release reflects very well the observed values. A novel result from the model is the indication that sediment nitrate uptake is a substantial component of the sediment-water dissolved nitrogen flux. Computed phosphorus flux is usually representative of the observed flux.

On an annual basis, the Sammamish River is computed to be the largest source of nutrients to Lake Washington, followed by the Cedar River and other distributed sources. The majority of the nutrient load is deposited in the sediments. A lesser amount leaves via Lake Union. The budget in this study was compared to the average of three most recent years, 1976-1978, reported by Edmondson and Lehman (1981). The nutrient loads of this study are 30 percent (nitrogen) to 60 percent (phosphorus) higher than the loads from the late 1970's. It cannot be said with certainty whether the disparity indicates a loading trend in the lake or differences in computational methods.

Considerable effort has been devoted to successfully modeling primary production in estuarine systems. The present estuarine model (Cerco and Noel in preparation) has two algal groups and two zooplankton groups. The estuarine model uses a quadratic term to represent additional predation on phytoplankton by microheterotrophs. The quadratic term has been found to be a key to computing both phytoplankton biomass and production. It is understood that the addition of zooplankton to the Lake Washington model is planned. The addition of multiple algal groups is also under consideration. The addition of zooplankton will require modification of the present algal predation term. Adoption of a quadratic formulation is recommended. The sponsor may also wish to explore alternate formulations. With some effort, the observed Lake Washington production pattern can be modeled. Complete confidence in modeled production 
requires, however, a comprehensive, consistent database of contemporary observations for comparison with the model.

Two approaches can be adopted to improve representation of the vertical variation in respiration. The first is to differentiate labile and refractory dissolved organic carbon in the model. This approach requires substantial activity in coding and also requires a means to distinguish loads and boundary conditions for the multiple carbon forms. A second approach is to employ lower first-order dissolved organic carbon mineralization rates below the thermocline. This second approach is recommended.

Lake Washington is the first application of the sediment diagenesis model to a lake. It is believed that the results are most satisfactory. The successful application is due partly to the absence of anoxia in Lake Washington. Under anoxic conditions, the diagenesis model represents estuarine conditions in which reduction of sulfate to sulfide is the dominant process. Reduction and oxidation of iron are not addressed in the present model code although developmental work has been conducted in this area (DiToro 2001). Application of the model to an anoxic lake, such as Lake Sammamish, may require inclusion of iron dynamics into the diagenesis and water column models.

Apparent, substantial increases in nutrient loading to Lake Washington since the late 1970's were detected. Extensive analyses were not conducted to verify the apparent increase. Certainly, increased nutrient loading is consistent with development trends in the watershed and with increased loading observed to coastal systems nationwide. The sponsor should conduct necessary sampling and analyses to determine if nutrient loading to Lake Washington is, indeed, increasing.

\section{References}

Cerco, C., and Noel, M. "The 2002 Chesapeake Bay eutrophication model" (in preparation), U.S. Army Engineer Research and Development Center, Vicksburg, MS.

DiToro, D. (2001). Sediment flux modeling. John Wiley, New York.

Edmondson, W. T., and Lehman, J. (1981). "The effect of changes in the nutrient income on the condition of Lake Washington," Limnology and

Oceanography 26(1), 1-29.

Gallegos, C., Correll, D., and Pierce, J. (1990). "Modeling spectral diffuse attenuation coefficient, absorption and scattering coefficients in a turbid estuary," Limnology and Oceanography 35, 1486-1502.

Johnson, B., Kim, S., Nail, G. (2003). "A three-dimensional hydrodynamic and temperature model of Lake Washington," prepared for King County Department of Natural Resources and Parks, Seattle, WA. 
Johnson, P., Bouchard, K., Goetz, F., Ebel, C., Carroll, A., Fox, A., Husby, J, Vanderven, M., and Lawrence, L. (2004). "Evaluation of strobe light effectiveness, and estimation of culvert entrainment and juvenile salmon passage at Hiram M. Chittenden Locks, Seattle, WA in 2002." Draft Technical Report to the U.S. Army Engineer District, Seattle, Seattle, WA. 


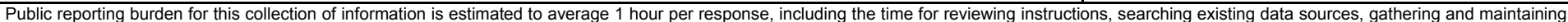

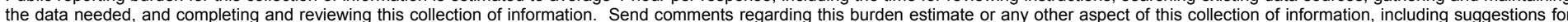

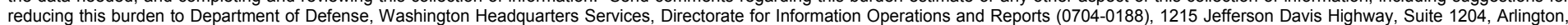

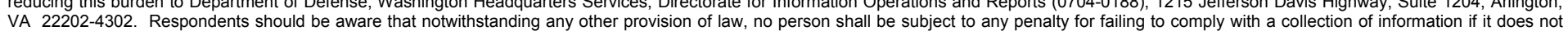
VA 22202-4302. Respondents should be aware that notwithstanding any other provision of law, no person shall be sube
display a currently valid OMB control number. PLEASE DO NOT RETURN YOUR FORM TO THE ABOVE ADDRESS.

\begin{tabular}{l|c}
$\begin{array}{l}\text { 1. REPORT DATE (DD-MM-YYYY) } \\
\text { August } 2004\end{array}$ & $\begin{array}{c}\text { 2. REPORT TYPE } \\
\text { Final report }\end{array}$ \\
\hline
\end{tabular}

\section{TITLE AND SUBTITLE}

Three-Dimensional Eutrophication Model of Lake Washington, Washington State

Three-Dimensional Eutrophication Model of Lake Washington, Washington State

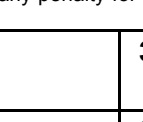

3. DATES COVERED (From - To)

\section{5a. CONTRACT NUMBER}

5b. GRANT NUMBER

5c. PROGRAM ELEMENT NUMBER

\section{AUTHOR(S)}

Carl F. Cerco, Mark R. Noel, Sung-Chan Kim

5d. PROJECT NUMBER

5e. TASK NUMBER

5f. WORK UNIT NUMBER

\section{PERFORMING ORGANIZATION NAME(S) AND ADDRESS(ES)}

8. PERFORMING ORGANIZATION REPORT

U.S. Army Engineer Research and Development Center

Environmental Laboratory

3909 Halls Ferry Road, Vicksburg, MS 39180-6199 NUMBER

ERDC/EL TR-04-12

9. SPONSORING / MONITORING AGENCY NAME(S) AND ADDRESS(ES)

10. SPONSOR/MONITOR'S ACRONYM(S)

King County Department of Natural Resources and Parks

201 S. Jackson Street, Suite 700

Seattle, WA 98104

11. SPONSOR/MONITOR'S REPORT NUMBER(S)

\section{DISTRIBUTION / AVAILABILITY STATEMENT}

Approved for public release; distribution is unlimited.

\section{SUPPLEMENTARY NOTES}

\section{ABSTRACT}

The CE-QUAL-ICM three-dimensional eutrophication model was applied to Lake Washington, northwestern Washington State, for the period 1995-1997. Transport processes were obtained from the companion CH3D-WES hydrodynamic model. The model activated 18 state variables in the water column including physical variables; phytoplankton; multiple forms of carbon, nitrogen, and phosphorus; dissolved oxygen; and fecal coliform. The model provided excellent representation of the annual cycle of temperature, chlorophyll, nutrients, and dissolved oxygen in the lake. The vertical structure was also well-represented. The water column was coupled to a predictive sediment diagenesis model that computed sediment-water fluxes of dissolved oxygen, methane, ammonium, nitrate, and phosphate, based on computed inputs of particulate organic matter. Computed values of deposition and fluxes were in reasonable agreement with published values. Nutrient loads were calculated and nutrient budgets were constructed as part of the model exercise. Load sources included river inflows, distributed loads, sewer overflows, and atmospheric loading. The Sammamish River was identified as the largest source of nutrients to Lake Washington, followed by the Cedar River and other distributed sources. The majority of the nutrient load is deposited in the sediments. A lesser amount leaves via Lake Union. Nutrient loads in this study were 30 percent (nitrogen) to 60 percent (phosphorus) higher than the loads from the late 1970's.

\section{SUBJECT TERMS}

CE-QUAL-ICM

Lake Washington

Eutrophication Mathematical model

16. SECURITY CLASSIFICATION OF:

\begin{tabular}{|l|l|l|}
\hline $\begin{array}{l}\text { a. REPORT } \\
\text { UNCLASSIFIED }\end{array}$ & b. ABSTRACT & c. THIS PAGE \\
UNCLASSIFIED & UNCLASSIFIED \\
\hline
\end{tabular}

\begin{tabular}{|l|c|}
$\begin{array}{l}\text { 17. LIMITATION } \\
\text { OF ABSTRACT }\end{array}$ & $\begin{array}{c}\text { 18. NUMBER } \\
\text { OF PAGES }\end{array}$ \\
& 170 \\
&
\end{tabular}

19a. NAME OF RESPONSIBLE PERSON

19b. TELEPHONE NUMBER (include area code) 